\title{
The syntax and morphology of nominal modification in Ògè
}

\author{
Inauguraldissertation \\ zur Erlangung des Grades eines Doktors der Philosophie \\ im Fachbereich Neuere Philologien \\ der Johann Wolfgang Goethe-Universität \\ zu Frankfurt am Main
}

vorgelegt von

Priscilla Lọlá Adénúgà

Aus

Eruku, Kwara-state, Nigeria.

2020

Einreichungsjahr: 2020

Erscheinungsjahr: 2021

1. Gutachter: Dr. Peter Smith

2. Gutachter: Prof. Dr. Oládiípọ Ajíbóyè 
(C) Priscilla Lọlá Adénúgà

All rights reserved 2021 


\section{Dedication}

This dissertation is dedicated to my husband, my children and my dad. Adéniyì, Oluwatimílẹhìn and Bólúwatifẹ Mr M.A. Ogundele (DSP) rtd. 


\section{ACKNOWLEDGEMENTS}

First and foremost, I give glory and adoration to the Almighty God the author and the finisher of my faith, the I am that I am, the Alpha and Omega, the beginning and the end, the Jehovah Jireh, the maker of me and the salvation of my soul. I can't thank him enough.

I will forever be grateful to my supervisor, Dr. Peter Smith. I want you to know that you are a great teacher, a patient tutor and an inspiring scholar. I learned a lot from your skilful way of syntactic analysis and your teaching. Thank you for the emotional support that you and your wife, Dr. Beata provided for me at a very difficult time of my life. All these wouldn't have been possible without the patience and cooperation of Kian and Nieve, I appreciate and cherish you both. And to my second supervisor, Prof. Oládiípọ Ajíbóyè, I thank you for your help and encouragements throughout my academic journey. Thank you for accepting to be part of the journey even at a very short notice.

My journey to this present point wouldn't have been possible without Victor Manfredi, who always reminds me that $\mathrm{I}$ have the potentials of pursuing a $\mathrm{PhD}$ in my chosen area of specialization. Ògá mi àtàtà, as I fondly call you, I appreciate your efforts, suggestions, encouragements and the constant push. Ẹ seun mo dúpẹe ọ̀nà ọpẹ́ mi pọ̀ lọdọ̀ yín.

My profound gratitude goes to Heidi Klockmann. You believed in me even at a time when I wasn't sure of my capabilities. You constantly reminded me of how interesting and relevant any piece of work that I give to you to read is. You lifted my spirit and rekindled the fire of research in me. I want you to know that I own a lot to you. I appreciate your selfless efforts on my work. Thanks to you, Heidi (my adopted mummy). Many thanks to Zheng Shen (BOSS). Despite the strangeness of Ògè, you always took your time to listen to me and to check through my often very long data. Thank you for your time and for all the criticism, I can tell you that all those only made me think deeply about my data and my analysis.

These whole journeys wouldn't have been possible without the help and financial support of the Deutsche Forschungsgemeinschaft (DFG) through the Research Training Group (RTG) on Nominal Modification, at Goethe University in Frankfurt. I appreciate the opportunity that was given to me to move to Germany to pursue my $\mathrm{PhD}$. This is one of the most amazing things that has ever happened in my life. With the financial support from the group, I have been able to travel to conferences and workshops where I presented my work with joy. I also had the opportunity to listen to great scholars from both far and 
near. I count myself as one of the lucky individuals that benefitted from this great gesture. Since the first day that I got accepted for this position, I have vowed to do my best to achieve that, that I was given the opportunity to come to Germany to achieve. Today, I look back to the year I started this journey and I can say 'to every race, there is a stop'.

Prof. Caroline Fery, thank you for your care, your help and your willingness to make me comfortable in Germany at the start of my study. You are such a generous woman with a kind heart. Thank you for inviting me to your house for my first Christmas in Frankfurt. And to Prof. Esther Rinke, I cannot possibly thank you enough for your help even at the time that I know it wasn't convenient for you. I still find it difficult to understand how you managed your time to read and comment on my work while at the same time supervising your students and carrying out your duty as the spokesperson of the group. I am happy to have worked and learned under you and I must confess that I learned a lot about how you treat and attend to the needs of your students.

I owe special thanks to Prof. Artemis Alexiadou who took her time to read chapter 5 of this dissertation. And to Prof. Guglielmo Cinque for taking his time to read chapters 3 and 4. I appreciate your valuable comments on the chapters.

My first reader, Francesco Pinzin, thank you for your immeasurable help in reading through the draft of my chapters, I secretly named you 'my first reader' solely because of this role that you played in this journey. Thank you for your time in struggling to understand a language that is obviously not familiar to you. Thanks for raising all the interesting and thought-provoking questions. Your role in this journey is well appreciated.

I have benefitted from the discussions with the members of my group, Fenna, Abby, Astrid, Melly, Lai, Ruby, Sanja and Lydia! You guys are the best. I am surely going to miss you all. And to our coordinator, Derya Nuhbalaoglu, thanks for your support.

At some point in the writing phase, I was overwhelmed with uncertainties, so I decided to join a group 'American Women's International Club' (AIWC). Thanks to all the members of this great club in which I find solace after very long hours of writing in the library. I also thank the staff of Landesbibliothek, and Mauritius Library, Wiesbaden and all the members of St. Augustine's church in Wiesbaden.

I cannot possibly thank my language informants enough for their willingness to supply me with all required sentences, clauses, phrases, words and even the translation of the data. Chief Odẹmo, my landlord in Ògè! I call him my landlord in Ògè because I have a 
room, reserved for the duration of my stay any time I visit Ògè. My food is always brought to my room and I do receive a special treatment from his family members. May you live long Baba to reap the fruits of your labor. The Ọwágè of Ògè, Ọba Alexandra Sànúolu Jimoh, Sẹ̀kẹ̀kẹkẹ Adòdó II. You received me with open arms in 2011 when I started my master's degree and wanted to work on the focus constructions in Ògè. Despite your age, you are always ready to communicate with me over the phone for hours without complaining. You introduced me to virtually every individual that matters in Ògè. You took your time to tell the people of Ògè how important it is to study the structure of the language and most importantly, get it written somewhere somehow. Kábíyèsí, I appreciate your kindness. Kí adé pẹ lórí, kí bàtà pẹ lệsẹ̀, kí ìrùkẹ̀rẹ pẹ lộwọ́, kí ẹmí ọba gùn! Àsẹ. Your support in my research journey is priceless. Sheu, my principal language informant. Although this is not your real name, but I decided to call you 'Sheu' because I see you as the director of my steps anytime I set my foot in Ògè. You go all the way to call all your friends to our meetings just to analyze or translate some of the folktales. Without your support Sheu, all I achieved in translating, transcribing and labelling of the folktales wouldn't have been possible. I know I owe you a lot to this.

To my amazing, wonderful and supportive husband, Ọmọ ọba Adénúgà. A woman who finds an encouraging husband has a great blessing. I count myself as being lucky to have you as my husband. 'Okay so then, I am done with the $\mathrm{PhD}$, what next?' And your response is always, 'oh, of course, continue to climb the ladder, I know that a day is coming that I will be the husband of a Professor'. Adéníyì, your support in my career is immeasurable. Your gentle push is priceless, your patient at the most difficult phase in the writing period is well appreciated. The loneliness you had to deal with when the going was tough for me is a huge support. Your role as both the father and the mother to our children when I am away to conferences, workshops, retreats are well appreciated. O sé ọkọ mi, Olówó orí mi, Adé mi. I hope that one day, your wish for me in my academic journey will come to a reality. And to my children, Olúwatìmílệhìn and Bólúwatifẹ́, you both know that I love you so much. Now, I can say that over the years, I have been able to train two young linguists independently. Yes, I say this because you are always my first listeners. I present my talks and posters to you before I go out to face my audience. So, I named you both 'my first audience'. To my amazement, after some of my talks, you guys started asking questions that showed that you both are interested in knowing more 
about what mummy does, like, 'Mum, what is the meaning of canonical position? Can you please explain Non-inflectional plural marking?' Now, God has answered your main prayer point by allowing mummy to pass her $\mathrm{PhD}$ ! Thank you, guys, for your understanding and for your patience while sitting with mum for hours in the various libraries in Wiesbaden!

Further, I will like to appreciate my family, especially my dad who already started to refer to me as Dr. even when I was still struggling with the dissertation. Dad, you believed in me so much. Thank you for your encouragements along the line. Thank you for your morning prayers and thank you for telling me constantly that if I set my mind on it, then I will achieve it. I love you dad. And to my mum and my siblings, I say a very big thank you for listening to my very long narratives that are of less importance to you. I know that you all understood that there are times that I will like to talk just to free my mind of the difficulties of coming up with a $\mathrm{PhD}$ dissertation.

Finally, I will like to appreciate the support of my mentors and friends: Dr. Bolanle Arókoyọ̀, Prof. Gbenga Fákúnàdé, Dr. Shọla Adénẹkàn, Students Ambassadors of the Linguistic Society of America 2019/2020, Mr. and Mrs. Aborìsàdé, Sabine Littig, Suzana Fong, İyá Àmúsàn, Queen, Abíólá Adéwálé, my colleagues at the Department of Linguistics and African Languages, Kwara-state University, Malete, Nigeria, Goshen Ladies club of Eruku city, and all the members of Oyun Baptist High School, old Students Association (OBHS). 


\begin{abstract}
This dissertation investigates several aspects of nominal modification in Ògè, an understudied language of Benue-congo spoken in Àkókó Northwest in Nigeria. The study focuses on two areas of nominal modification namely, Nominal Attributive Modifiers
\end{abstract} (NAMs) and the strategies of number marking.

The discussion and analysis of NAMs in the language reveal that Ògè belongs to the group of languages which lacks adjectives as a lexical category. NAMs are nominal and they are derived from an existing lexical category namely, verbs. Predicative modifiers and NAMs have forms that are similar to the long and short forms (LF \& SF) of adjectives in languages in which adjectives form an open class, for example, Russian, SerBoCroatian (BCS) and German. Based on the Minimalist program, the dissertation reveals that unlike Russian, BCS, and German in which the discrepancies between the two forms of adjectives are related to definiteness (as in the case of BCS) and Agree, the discrepancies in the two forms of modifiers in Ògè are related to the fact that Ògè lacks adjectives and resorts into the nominalization of stative verbs in order to derive attributive forms. Using the analyses of adjuncts according to Truswell (2004) and Zeijlstra (2020), the dissertation proposes that NAMs are adjuncts in a modification structure while they are heads in possessive and genitive constructions. In addition, I propose that NAMs are attributive-only modifiers which modify the NP rather than the DP.

The dissertation also investigates the strategies of number marking in Ògè. Unlike languages in which number marking is obligatory in the nominal domain (Hebrew, German, English), nouns in Ògè are not always marked for number. This means that nouns in Ògè have general number. The general number nature of nouns in Ògè is like that of the nouns in modifying plural marking languages namely, Halkomelem, Korean, 
Yucatec Maya and Yorùbá. However, I argue that unlike the modifying plural marking languages in which the Number Phrase (NumP) is not projected, NumP is projected in the nominal spine of Ògè, claiming that NumP bears an interpretable number feature which values the uninterpretable number feature in D. Argument in support of this comes from the interpretation of the noun in the presence of oturro (an element which translates to the plural definite interpretation of the noun). I analyze otúro as a plural determiner which occupies the D-head in the syntax of Ògè. The dissertation argues following Alexiadou (2019) that the locus of the occurrence of the marker of plurality in the nominal spine does not depend on its interpretation as a plural morpheme, rather, the locus of the occurrence of the element that is sensitive to the plural interpretation of the noun depends on other parameters which are definiteness, specificity and animacy. 


\section{LISTS OF TABLES}

Table 2.1 Specificity marking variations in Ògè, Yorùbá and English 48

Table 3.1 Strong adjectival inflections in German 62

Table 3.2 Weak adjectival inflections in German 62

Table 5.1 Personal singular pronouns in Ògè 202

$\begin{array}{lll}\text { Table 5.2 Personal plural pronouns in Ògè } & 202\end{array}$

$\begin{array}{lll}\text { Table 5.3 Emphatic pronouns in Ògè } & 204\end{array}$ 


\section{LISTS OF GLOSSING ABBREVIATIONS}

1

2

3

ACC

ADJ

AGR

ASP

ATTR

$\mathrm{BN}$

$\mathrm{CL}$

COMP

COP

DECL

DEF

DEM

DET

DIST

DM

D

EMPH

FEM

FI

FOC/FP

FUT

GEN

HTS

IF

INDEF

INFL

IM

first person

second person

third person

accusative

adjective

agreement

aspect

attributive

bare noun

classifier

complement

copula

declarative

definite

demonstrative

determiner

distal

direct modification

determiner

emphasis

feminine

full interpretation

focus phrase

future

genitive

high tone syllable

interpretable feature

indefinite

inflection

indirect modification 


\begin{tabular}{|c|c|}
\hline LF & logical form \\
\hline LOC & locative \\
\hline MASC & masculine \\
\hline MTS & mid tone syllable \\
\hline NEG & negation \\
\hline NEUT & neuter \\
\hline NMLZ & nominalization \\
\hline NOM & nominative \\
\hline NP & noun phrase \\
\hline NUMP & number phrase \\
\hline REL & relative clause \\
\hline RESUMP & resumptive pronoun \\
\hline PST & past \\
\hline PERF & perfect \\
\hline $\mathrm{PF}$ & phonetic form \\
\hline PL & plural \\
\hline POSS & possessive \\
\hline PP & preposition \\
\hline PRED & predicative \\
\hline PROG & progressive \\
\hline S & semantics \\
\hline SAL & salient \\
\hline SF & short form \\
\hline SG & singular \\
\hline SPEC & specifier \\
\hline SP & specificity \\
\hline TOP & topic \\
\hline TR & transitive \\
\hline $\mathrm{uF}$ & uninterpretable featur \\
\hline
\end{tabular}




\section{TABLE OF CONTENTS}

\section{Dedication}

\section{Acknowledgements}

\section{Abstract \\ List of Tables \\ List of Glossing Abbreviations}

\section{Chapter 1: Introduction and Background}

1.1. Introduction 1

1.2. General theoretical assumptions in the dissertation 2

1.3. Data 5

1.4. Overview of the dissertation 6

\section{Chapter 2: The structure of nominal expressions in Ògè}

2.1. Introduction 9

2.2. Bare Nouns (BNs) in Ògè 13

$\begin{array}{ll}\text { 2.2.1. BNs in argument positions } & 17\end{array}$

2.2.2. BNs in predicate positions 21

2.2.3. Towards an analysis of the syntactic structure of nominal expressions in Ògè 22

2.3. Analysis of the syntactic structure of nominal expressions in Ògè 25

2.3.1. The DP Hypothesis 26

2.3.2. A preliminary analysis of Ògè nominal expressions 28

2.4. Demonstratives in Ògè 33

2.4.1. Functions of the demonstratives in Ògè 36

2.4.2. Syntactic position of the demonstratives in Ògè 37

2.5. Additional elements in the DP of Ògè 41

2.5.1. The specificity marker in Ògè 42

2.5.2. Syntactic analysis of rin in the functional projection of the NP 49

2.5.2.1. Rin, an instance of the specificity head (Sp) 51

2.5.2.2. Evidence in support of phrasal movement 53 
Chapter 3: Internal syntax of Nominal Attributive Modifiers (NAMs) in Ògè

3.1. Introduction 56

3.2. Attributive versus Predicative adjectives. A cross-linguistic perspective $\quad 57$

3.2.1. The case of Russian $\quad 57$

3.2.2. Bosnian/Croatian/Serbian (BCS) 59

3.2.3. German 61

3.2.4. Interim Summary 63

3.3. Nominal Attributive Modifiers (NAMs) in Ògè 64

3.3.1.i -NAMs in Ògè $\quad 66$

3.3.1.1. Nominalizations in Ògè 70

3.3.1.2. Internal structure of $i$ - NAMs 73

3.3.2. a-prefix $\quad 75$

3.3.2.1. Focus Constructions in Ògè 76

3.3.2.2. Alternative analysis of focus constructions in Ògè 78

3.4. Nominal Attributive Modifiers in Yorùbá 81

3.4.1. NAMs in Group (GRP) I

3.4.1.1. Previous analyses of the internal structure of NAMs in Yorùbá 83

3.4.1.2. Yorùbá high tone is a syntactic category 86

3.4.1.3. Generalization about the high tone in GRP I in Yorùbá 89

3.4.2. NAMs in GRP II 91

3.4.3. Problem for a unified analysis 93

3.5. Verbal status of predicative forms in Ògè and Yorùbá 94

3.6. Implications of the analysis 98

$\begin{array}{ll}\text { 3.7. Summary } & 101\end{array}$

Chapter 4: The external syntax of Nominal Attributive Modifiers (NAMs) in Ògè

$\begin{array}{ll}\text { 4.1. Introduction } & 103\end{array}$

4.2. NAMs in argument positions 103

$\begin{array}{ll}\text { 4.2.1. NAMs in possessive expressions } & 104\end{array}$

$\begin{array}{ll}\text { 4.2.2. NAMs in genitive expressions } & 105\end{array}$ 
4.2.3. NAMs in isolation in Yorùbá

$\begin{array}{ll}\text { 4.3. NAMs, a Noun-Noun compound? } & 108\end{array}$

4.3.1. Evidence for a Modifier + Noun compounding 109

4.3.2. NAM + Noun, not a case of compounding in Ògè 111

4.4. A syntactic analysis of NAMs in attributive positions 113

4.4.1. A specifier-based analysis (Cinque 2010) 114

4.4.2.Head Analysis 115

4.4.3. Adjunction analysis of attributive adjectives 118

4.4.4. Optionality of NAMs in attributive positions 119

4.4.5. Problems with the label of adjuncts in the Minimalist Program 123

4.4.6. Problems of the traditional analysis of adjuncts for NAMs 126

4.4.7. Truswell (2004) 127

4.4.8.Zeijlstra (2020) 132

4.5. NAMs are dependent on the modified noun

$\begin{array}{ll}\text { (Selectional restrictions of NAMs) } & 136\end{array}$

$\begin{array}{lll}\text { 4.6. Summary } & 141\end{array}$

\section{Chapter 5: Number marking in Ògè}

$\begin{array}{ll}\text { 5.1. Introduction } & 142\end{array}$

$\begin{array}{ll}\text { 5.1.1 The data } & 144\end{array}$

5.1.2 Theoretical Background 146

5.2. Previous analyses of plural marking in languages (two standard views) $\quad 148$

$\begin{array}{ll}5.2 .1 \text { Head-marking plural languages } & 149\end{array}$

5.2.1.1 'Agree' in head-marking plural languages 152

5.2.1.2 Pluralia tantum 153

5.2.2 Modifying-plural marking languages 154

5.2.2.1 Halkomelem (Wiltschko 2008) 155

5.2.2.2 Korean (Kim \& Melchin 2018) 158

5.2.2.3. Yucatec Maya (Butler 2011) 160

5.3. Otúro and the modifying plural morphemes 163

5.3.1. The interaction of Òtúro with definiteness in Ògè 165

5.3.2.Plural interpretations: a parametric view? 168

$\begin{array}{ll}\text { 5.3.3. General Number } & 170\end{array}$ 
5.4. Number in Ògè: An analysis

5.4.1. 'Agree' in number marking in Ògè 178

5.4.2. Number sensitivity in D, an instance of 'Agree' 180

5.4.3. Demonstratives 182

5.4.4. BNs in Ògè: a case of general number? 186

5.4.5. The quantifiers İgào, ikúwọ́ and òtúro 188

$\begin{array}{ll}\text { 5.4.6. Interim summary } & 191\end{array}$

5.5. Ògè mass nouns are not compatible with òtúro 192

5.5.1. Mass nouns in Ògè 193

$\begin{array}{ll}\text { 5.5.2. Temporal Nouns } & 198\end{array}$

5.5.3. Mass Nouns in Ògè, towards an analysis 199

5.5.4. Pronouns in Ògè 200

5.6. General discussions 205

5.6.1 Plural sensitivity to animacy in Amharic and Korean 207

5.6.2. (In)definite interpretations of BNs or a plural noun in relation to animacy 210

5.7. Summary

\section{Chapter 6: Summary and concluding remarks}

$\begin{array}{ll}\text { 6.1. Introduction } & 216\end{array}$

6.2. Summary of findings 216

6.3. Contributions to linguistics research 218

6.4. Suggestions for further research 219

6.4.1. Nominal Attributive Modifiers (NAMs) 219

$\begin{array}{ll}\text { 6.4.2. External syntax of NAMs } & 220\end{array}$

\section{Appendix A}

$\begin{array}{ll}\text { Some names of my language informants } & 222\end{array}$

$\begin{array}{ll}\text { Impressions from my fieldwork trips } & 223\end{array}$

\section{Appendix B}

Some short stories in Ògè without the glossing (For the full glossing, constituent labelling and the audio of the stories, please see 
Story 1. Úwan Elechui sọn (The Beautiful girl)

Story 2. Úwan Adìdọ

(The story of the dumb child)

Story 3. Ọran

(The story of the Bird)

Story 4. Agọgó

(The story of the Tortoise)

Story 5. İjàn

(The story İjàn town)

References 


\section{Chapter 1: Introduction and Background}

\subsection{Introduction}

This dissertation investigates various aspects of nominal modification in Ògè with specific interest in the structure of adjectival modification and number marking strategies. Relevant characteristics of adjectives in Ògè, a Benue-Congo language spoken in Nigeria are discussed. Many of the African languages are considered to have a closed class of Adjectives (Welmers 1973; Dixon 2004) unlike the European languages in which adjectives form an open class from which varied lexical items are derived. The main issue of discussion in the literature remains the existence of a closed class of adjectives in most of the African languages (adjectives are derived from other lexical items like nouns and /or verbs). Segerer (2008) argues in favor of the closed class of adjectives by providing empirical data from some of the African languages i.e., Igbo, Edo, Yorùbá, some Bantu languages and some data from Chadic languages. According to Segerer, some of the African languages with an open class of adjectives include Mbum, Tikar, Tigrigna. Among those languages where the class is closed, the number of items range from 2 (e.g., Kemantney or Keley) to more than 100, e.g., Dagbani.

Using existing theories of syntax, the aims of this dissertation among others include (i) the analysis of the structural architecture of adnominal adjectives (in this sense, attributive and predicative use of the adjectives) (ii) analyze the structural location of adnominal adjectives in Ògè. (iii) a comparative study of adnominal adjectives in Ògè and Standard Yorùbá (a closely related language to Ògè). Aiming at making clear the identity of adjectives in Ògè, there are two directions in which the dissertation approaches these issues. First, an in-depth analysis of the nominal domain of Ògè is given using the 
Minimalist theory, this is given in chapter two in which the structure of the determiner phrase of Ògè is discussed.

The second part of the dissertation (chapters 3 and 4) aims at examining the different perspectives taken by some scholars on adjectives cross-linguistically. The importance of this part of the dissertation is not only to re-examine some of the claims about the Adjective category in the selected languages, but also to point out succinctly why these languages differ 'structurally' or otherwise from adnominal modifiers in Ògè. As a way of an insight into what is intended to be carried out in this part of the dissertation, the questions arise as to; (a) why adjectives inflect differently from predicative adjectives? (b) why does the structure of the adjective category differ from its structure when it performs the function of predication in some languages but not in other languages?' A major finding of the discussion in this chapter is that 'attributive adjectives' are nominal in Ògè (therefore, adjectives are called Nominal Attributive Modifiers (NAMs), in this dissertation). If attributive adjectives are nominal in Ògè, the question arises as to how number are marked in the language. In some languages, number is marked on the adjective and not necessarily on the noun since adjectives are nominal and it is assumed to be able to take a plural marker. This is the focus of the discussions and analysis in chapter five (5) of the dissertation.

\subsection{General theoretical assumptions in the dissertation}

The theoretical framework that is adopted in the dissertation is the minimalist theory of syntactic feature specifications as laid out in (Chomsky 1995, 2001, 2002; Adger 2003, 2010; Zeijlstra 2014, 2020). Adger (2003) defines features as properties of syntactic atoms. This allows features to enter relationships with other syntactic atoms. For example, an interpretable feature is said to be able to enter a relationship with a counterpart feature 
that is not interpretable. Two approaches are adopted regarding the use of features. The first as to do with the famous interpretable and uninterpretable features as elaborated in (Adger 2003, 2010; Chomsky 1995, 2000, 2001; Zeijlstra 2014) while the second is referred to as dependent and independent [DEP] features in the sense of categorial grammar (Zeijlstra 2020).

The syntactic analyses adopted in chapters 2, 3 and 5 assume an interpretable and uninterpretable feature as extensively elaborated by (Adger 2003, 2010; Chomsky 1986, 1995b, 2000, 2001; Zeijlstra 2014). When a category bears an interpretable feature, the category is interpreted as carrier of the semantics of the feature while uninterpretable features are features that are only formal features and not semantic in nature and they cannot receive an LF-interpretation (Zeijlstra 2014).

The analysis of NAMs in chapter 4 shows that the combinatorial syntactic, possibilities of the mother node are determined by both daughters which are the attributive and the modified noun. However, the original assumptions in the literature is that when an adjunct is merged, the adjunct is redundant while its sister projects which is syntactically the head of the noun phrase. This is illustrated in Chomsky (1998) ' $\ldots$ in a sequence of $\mathrm{K}=(\mathrm{y},\{\mathrm{a}$, b) , y is the label for the merger of $a \& b$ in which $y$ (the label of the derived syntactic object) needs to be identical to $a$ or $b$, for example, one of the sisters projects its label while the other sister is redundant (an adjunct)'. The dissertation reveals that an adjunct in a modification structure is active. In other words, attributive, despite its optional status is not redundant in syntax, rather it is involved in feature checking and feature percolation; the feature of an attributive is [N, DEPN] as exemplified in (1). 
(1)

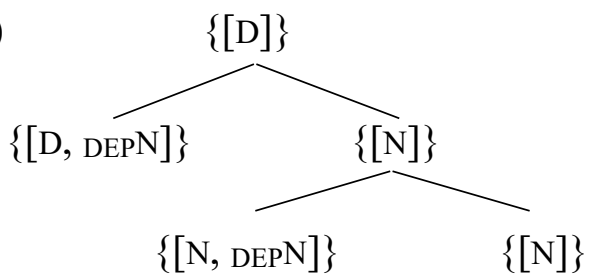

The structure in (1) is supported with ample evidence from the analysis of adjuncts in Truswell (2004) and Zeijlstra (2020). Here, the claim is that the label of the concatenation of NAM with the noun is derived through the combinatorial function of both sisters (attributive and the modified noun). This means that both merged objects contribute to the label of the derived syntactic object. The interesting task in the merger of the attributive with the modified noun will be the label of the set consisting of two sisters with an identical lexical category: an attributive with the feature [N] modifies a noun with the feature $[\mathrm{N}]$. The feature [DEP] on attributives as shown in (1) shows that attributives in Ògè are dependent on the modified noun and they must be adjacent to the modified noun, which are the heads of the NP. Basically, the argument in chapter 4 is twofold i) NAMs are introduced into a syntactic structure for the purpose of modification (ii) there is syntactic dependency relationship between the NAM and the modified noun. ${ }^{1}$

In chapter 5, following Chomsky $(1995,2002)$ and Zeijlstra (2020), I take Agree as an operation which checks whether the attributes of an unvalued and a valued feature match, and then value the unvalued one to be the same as the one its agreeing with. ${ }^{2}$ Take for instance, if the Number feature on Num is PL and the number feature on D is unvalued for

\footnotetext{
${ }^{1}$ The analysis proposed here is in the sense of categorial grammar in which an item depends on the existence of an adjacent item for its survival. This analysis could be extended to any relationship between an adjunct-sister sequence such as Adv-V sequence as well. As shown in section 4.5., in chapter 4, the intriguing part of this analysis is that it allows for the transparency of the merger of the modifier with the modified noun.

${ }^{2}$ In this sense, Agree does not just check whether a dependent and an independent feature match by checking the dependent one rather, Agree is a feature driven mechanism between a probe and a goal which have a matching feature.
} 
number, represented as ' $\mathrm{D}[\mathrm{uNum:}]$ ', what Agree does is that it gives a value to the unvalued uninterpretable number feature on D, which will then be written as D[uNum: PL]. This is further illustrated in (2).

\section{(2) Agree \\ $\mathrm{X}[\mathrm{F}: \mathrm{val}] \ldots \mathrm{Y}\left[\mathrm{F}_{-}\right]$}

The value from [F:val] is copied to $\mathrm{Y}[\mathrm{F}:]$, resulting in $\mathrm{X}[\mathrm{F}: \mathrm{val}] \ldots \mathrm{Y}[\mathrm{F}: \mathrm{val}]$

The features $\mathrm{X}[\mathrm{F}: \mathrm{val}]$ and $\mathrm{Y}[\mathrm{F}:]$ in the configuration in (2) help to distinguish between the features that seek a value from those features that do not require a value. For instance, the [u Num:_] on D indicates a dependency relation between the D-head and the Numhead while the empty space after the colon on the uninterpretable feature on Num, shows that the Num needs a value either PL or SG. This is an instance of structure enrichment where the features present on one node are spread onto other nodes, 'Agree' is assumed to establish a Probe-Goal relation, the goal bears an inherent feature which are specified on the features on the probe. In this analysis, the features on the probe are derived from the features on the goal through agreement.

\subsection{Data}

To the best of my knowledge, published works on Ògè are my own research on different aspects of Ògè. Examples of these are, Adénúgà (2015, 2017, 2019). My master's dissertation on focus constructions in Ògè (unpublished) gives a comprehensive description of the phonological system of Ògè which includes the consonant, and vowel systems, as well as tone and prominent phonological processes. It is worthy of mention that the phonological systems in Ògè do not diverge in significant ways from the phonological systems of Yorùbá which is a well-studied language in the literature. 
The Ògè data in this dissertation come from my own fieldwork. The fieldwork data were collected during several field trips to Ògè as well as surveys (on the phone) with the native speakers of Ògè. I started to work on different aspects of the noun phrase of Ògè in 2005 when I wrote a long essay on the Noun Phrase in Ògè. In 2014, I wrote my master's thesis on the Focus constructions in Ògè. During this period, I recorded short stories in Ògè (see appendix for some of the stories). At the start of my doctoral dissertation, I went back to Ògè to record more stories with specific focus on nominal modifiers. Lastly, towards the end of 2019, I went back to Ògè for the purpose of data clarifications. This time, the emphasis was on the status of bare nouns in relation to articles (both the singular and plural articles), nominal attributive modifiers and number marking. The names of my numerous consultants and some of the pictures that were taken during the fieldtrips are included in the Appendix.

\subsection{Overview of the dissertation}

Chapter 2 discusses the nominal phrase in Ògè and provides an analysis of the lexical and functional elements that make up a noun phrase. The chapter provides answers to the following questions:

(i) Does the NP in Ògè project a DP?

(ii) Can Ògè be classified as an articleless language?

(iii) Does the article in Ògè compete with other elements in the postnominal position?

(iv) What is the role of the articles in Ògè?

The chapter presents the structure of the nominal constructions in Ògè and expatiates the necessity of a DP projection above the NP layer. With the help of the syntactic features (the weak and strong features on two distinct heads), evidence for phrasal movement is 
provided for the analysis of the specificity marker and the possessive pronoun which show a phrasal movement from their canonical position to a derived position for the purpose of feature checking.

Chapter 3 and Chapter 4 present the analyses of NAMs in Ògè. The focus of chapter 3 is the syntactic analysis of the internal structure of NAMs in Ògè. The chapter claims that attributives are nominal and that they are derived from stative verbs. Chapter 3 starts out with a brief discussion of the adjectives in some selected European languages and shows that the discrepancies in the two forms of the adjectives which are the attributive and predicative forms are because of two parameters; agreement and definiteness. A comparison of the attributive modifiers in Ògè and Yorùbá help to establish that adjective is not a universal category because all the attributives are derived from an existing lexical category (verbs) in the two languages. The reason for this comparison is because Yorùbá is one of the best studied Niger-Congo languages, as well as the lingua franca of the Ògè community.

Having analyzed the internal structure of NAMs in chapter 3, the focus of chapter 4 is on the structural location of NAMs in the noun phrase in relation to the modified noun. The attributive is analyzed as a nominal element which adjoins to the modified noun in a nominal modification expression. NAMs are direct only modifiers as such, no elements can intervene between the NAM and the modified noun.

Chapters 3 and $\mathbf{4}$ provide answers to the following questions:

(i) Are adjectives universal? Is 'adjective' as a lexical category present in Ògè?

(ii) What cross-linguistic generalizations can be drawn about adjectives as a category?

(iii) What is the structure of NAMs in Ògè?

(v) Why are predicative and attributive modifiers structurally and categorically different in Ògè? 
(vi) What is the structural location of NAMs in the nominal phrase of Ògè?

Chapter 5 discusses the strategies of number marking in Ògè. The chapter shows that nouns in Ògè are optionally marked for plural with òtúro. It further argues for a NumP projection in the nominal spine of Ògè and shows that in addition to the marking of plural, otúro marks a noun for definiteness. It is well known in the literature (Wiltschko 2008; Kramer 2015; Butler 2011; Kim \& Melchin 2018) that the NumP does not project in languages with optional plural morpheme. The chapter argues that otúro is not always optional, its presence is required in a plural definite context. The host of oturo, which is the D, performs a dual function of (in)definiteness and number interpretations.

Chapter 5 provides answers to the following research questions:

(i) How are nouns marked for plural in Ògè?

(ii) Is there the need for the projection of a Num(ber) phrase in the nominal spine of Ògè since it is well-known that languages with a modifying plural marking system do not project a NumP?

(iii) Is the plural marker in Ògè associated with interpretations other than the marker of plurality?

This chapter reveals four important facts about the system of number marking in Ògè:

(i) Nouns in Ògè have general number.

(ii) Plural marked nouns are interpreted as plural only, singular nouns are interpreted as singular only while BNs could mean one or more than one.

(iii) NumP is compatible with languages in which nouns have general number (contra Wiltschko 2008).

(iv) Plurality may interact with definiteness and animacy.

Chapter 6 concludes by highlighting the main contributions of the dissertation. 


\section{Chapter 2: The structure of nominal expressions in Ògè}

\subsection{Introduction}

This chapter discusses the structure of the nominal expressions in Ògè. Some scholars like Boskovic (2009) assume that in some languages, the NP is not dominated by the projection of the DP (articleless languages e.g., Chinese) while in others, the NP is dominated by the projection of the DP (languages with obligatory articles, e.g., English and most of the Germanic languages). Nouns in Ògè can appear bare as shown in (1), and the noun can be interpreted as either (in)definite, singular or plural depending on the context in which it occurs.

(1)a. ópú

$\operatorname{dog}$

'a/the dog/ dogs'

b. áchọ

cloth

'a/the cloth/ cloths'

c. ẹnẹ

person

'a/the person/people'

However, just as it has been claimed for bare nouns (BNs) in some related languages, Aboh (1998), for Gungbe and Ajíbóyè (2005), (2009) for Yorùbá, I propose that the first mention of a BN in discourse in Ògè is construed as indefinite while a BN that is mentioned in discourse for the second time is construed as definite (this phenomenon is discussed in full in section 2.2.).

In addition to the bare nature of nouns in Ògè, nouns take some elements which are interpreted as either definite in the case of ikári in (2a) or indefinite as the interpretation 
of ikin shows in (2b). The ungrammaticality of the example in (2c) shows that both elements do not co-occur, and this suggests that both elements compete for the same position in the nominal phrase as argued in section 2.3.

(2) a. ikári ópú

DEF dog

'the dog'

b. ikín ópú

INDEF dog

'a dog'

c. *ikári/ikín ópú

The proposal that both elements ikári and ikin compete for the same position in the nominal projection of the NP is supported by the grammaticality of the example in (3) in which both elements are compatible with the demonstratives igé 'that' and ighẹ 'this'. The grammaticality of the examples in (4) suggests that the markers of (in)definiteness and the demonstratives occupy different layers in the projection of the NP in Ògè.

(3)a. ígé ópú

DEM dog

'that/those $\operatorname{dog}(\mathrm{s})$ '

b. íghẹ́ ópú

DEM dog

'this/these $\operatorname{dog}(\mathrm{s})$ '

(4)a. ikári ígé/íghẹ ópú

DEF DEM dog

'that/this dog' 
b. íkín ígé/ íghẹeópú

INDEF DEM dog

'that/this dog'

The chapter claims that the elements ikári and ikín are not grammatical in a plural context and this explains why they are not compatible with the marker of plurality oturro as shown in (5b and c) while the demonstratives are compatible with otúro as shown in (6). I assume that demonstratives are ambiguous between a singular and a plural interpretation in Ògè as the gloss in (3) shows and that the elements ikári, ikín and òtúro occupy the same layer which is the D-head in the projection of the NP. This assumption is further supported by the interpretation of the plural noun in (5a) as a definite plural.

(5)a. òtúro ópú

PL dog

'the $\operatorname{dogs} / * \operatorname{dog}$ '

b. *ikári òtúro ópú

c. *íkín òtúro ópú

(6)a. òtúro ígé ópú

PL DEM dog

'those dogs'

b. òtúro íghẹ ópú

PL DEM dog

'these dogs'

Additional elements in the nominal expressions of Ògè that are relevant for the analyses in this chapter are the specificity marker rin as shown in (7) and the possessive pronoun ràn 'my' as shown in (8). An interesting characteristic of both elements is that unlike the 
elements in the examples in (2-6) that occur in a prenominal position, rìn and ràn both occur to the right of the noun.

(7)a. ópú rìn

$\operatorname{dog} \mathrm{SP}$

'a/the specific dog'

b. ópú ràn

dog my

'my dog'

c. ópú ràn rìn

dog my SP

'my specific dog'

For the analysis of the structure of the nominal expressions in Ògè, section 2.2. discusses in detail the interpretations of BNs and shows that BNs in Ògè are grammatical in both argument and predicative positions. The section concludes that the articles are obligatory in contexts with unambiguous (in)definite and number interpretations. In section 2.3., following the proposal of Abney's (1987) DP-hypothesis, I propose that the projection of the NP is dominated by the projection of the DP. D is phonologically filled when the articles are overt while D is null in the case of BNs. In addition, I also assume that the Number Phrase (NumP) projects between the DP and the NP but that the Num is not phonologically filled (see chapter five for the full analysis of number in Ògè). Because of the characteristics of the elements in D as shown in the examples in (2a, b and 5a), I assume that $\mathrm{D}$ bears the feature [(IN)DEF, uNum] which takes a number specification from the Num. Here, the assumption is that Num bears an interpretable number feature [Num] that values the uninterpretable number feature on $\mathrm{D}$. 
Since the articles are compatible with the demonstrative, in section 2.4., I propose that the DP hosts an additional projection between the DP and the NP which is a demonstrative phrase (DEMP) and that the DEM, is occupied by the demonstrative, in this analysis, the DEMP is the complement of D while the NumP is the complement of DEM.

Further to the analysis in this chapter, section 2.5. develops an analysis in terms of a phrasal movement in the spirit of Aboh (1998) and Guillemin $(2009,2011,2014)$. In this respect, the proposal suggests that the host of the specificity marker is the Specificity Phrase (SpP) above DP which is an optional functional projection that is only projected when rin is overt. The chapter proposes that $\mathrm{Sp}$ bears a strong specificity feature which attracts its complement, the DP to [Spec SpP] for the purpose of feature checking (therefore we see the order of the elements in (7a)). The support for a phrasal movement further comes from the example in $(7 \mathrm{~b})$ in which the possessive pronoun occurs to the right of the noun followed by the specificity marker. Here, the assumption is that there is an additional projection between the DP and the NP, which is the Possessive Phrase [PossP]. The PossP bears a feature [Poss] which causes the movement of the NP to the [Spec Poss], see the example in (7b) and then the output of the movement of the DP to the [Spec Sp] yields the order in (7c). Section 2.6. gives the summary of the chapter.

\subsection{Bare Nouns (BNs) in Ògè}

The main concern of the present section is to describe the behavior of BNs in Ògè. Following Ajíbóyè (2005), (2009), I take BNs to be NPs which have no determiner and no specification for number. In other words, nominals in Ògè are most times 'bare' appearing in isolation without any accompanying element(s) in discourse. I give an overview of the discussions in this section while section 2.2.1. discusses the distribution of the $\mathrm{BN}$ in Subject and object positions and section 2.2.2. gives the interpretation of a BN in 
predicative position. To be more explicit about the status of BNs in Ògè, this section concludes that BNs in Ògè belong to the set of languages with an ambiguous bare singular and that its nouns are freer in all contexts.

As is well known, a nominal expression may contain both lexical and functional materials. If we compare the noun phrases in (8), we immediately note some similarities between English and Ògè. The English version of the nominal expression in (8a) contains a determiner, the definite article the, and the indefinite article $a$. The Ògè equivalent of the sentence in (8a) contains elements that correspond to the English (in)definite article: ikári is the definite article while ikin is the indefinite article. The grammaticality of (8c) shows that Ògè optionally marks (in)definiteness in its nominal expressions. The ungrammaticality of the sentence in $(8 \mathrm{~d})$ indicates that bare singulars are not grammatical without the articles in English.

(8)a. The teacher saw a dog in the class.

b. Ìkári tísà rì íkín ópú úrùn ìkári kíláàsì. DEF teacher see INDEF dog in DEF class

'The teacher saw a dog in the class.'

c. Tísà rì ópú úrùn kíláàsì.

Teacher see dog in class

'The teacher saw a dog in the class.'

d. *Teacher saw dog in class.

As shown in (2), repeated here in (9), both elements occur to the left of the noun just as it is in English and the noun is not ambiguous between a definite or an indefinite interpretation in such contexts. 
(9)a. ikári ópú

DEF dog

'the dog

b. íkín ópú

INDEF $\operatorname{dog}$

'a dog'

Both articles are interpreted as 'the' and 'a' respectively. This is quite different from the interpretation of the elements in the nominal phrase in other related languages. I will discuss briefly (see section 2.3. for the full discussion), the debate on the status of a related element called náà in Yorùbá. Bámgbósé (1974), analyzed náà as a determiner which he translates as 'the' in English.

(10) Yorùbá

asọ náà...

dress DEF

'the dress...'

(Bámgbósé 1974:45)

However, náà does not receive a direct interpretation; it could be interpreted as an adverb (Manfredi 1992) or as a salience marker (Ajíbóyè 2005) or as a specificity marker (Ajíbóyè 2009). Based on the varied interpretations of náà in Yorùbá, Ajíbóyè (2005) argues that nouns in Yorùbá are bare and he supports his claim with empirical data which shows that nouns in Yorùbá could be interpreted as definite without náà. The question now arises as to what the status of the nouns in Ògè is? Put in another way, are nouns in Ògè like nouns in Yorùbá (BNs) or English (with obligatory articles)? Regarding this question, I claim that nouns in Ògè are like nouns in English (when they occur with the 
article) on the one hand while they are like nouns in Yorùbá when they occur without the article. The grammaticality of (11) explains this further.

$\begin{array}{rll}\text { (11) a. Í } & \text { rì } & \text { ópú. } \\ 1 \mathrm{SG} & \text { see } & \text { dog }\end{array}$

'I saw the/a dog.'

b. Olùkọ́ sì úrun éswé.

teacher si PP house

'The teacher is in the house.'

Ògè nouns with no morphological marking in the grammatical positions show properties of articleless language ${ }^{3}$ The BNs in object position receive a definite interpretation in the equivalent interpretation into English. Ópú 'dog', olùkọ 'teacher' and éswé 'house' are grammatical in the various positions of occurrence $(11 \mathrm{a}, \mathrm{b})$ without an overt realization of the article.

As we know, certain nouns in English also appear without articles, e.g., generic (12a), mass nouns (12b), or bare plurals (12c).

(12) a. John likes dogs.

b. Rice is common all over the world.

c. I saw dogs on my way to the house.

However, the ungrammatical example in (8d) shows that (in)definite articles are not always optional in English unlike in Ògè in which the (in)definite articles are not required

\footnotetext{
${ }^{3}$ Bošković (2005), suggests the term articleless for languages which lack German articles such as der, die, or das along with their different declensions in German or English type articles such as the or $a$. According to him, the former term determinerless for such languages is not appropriate since such languages possess determiners such as (demonstratives, possessive pronouns and nouns or cardinal numbers).
} 
to appear with the noun in all contexts: bare singulars (8c), mass nouns (13a) and bare plurals (13b).

(13) a. Sadé kò ùji.

Sade take water

'Sade took water.'

b. Í rì ópú ùwà

$1 \mathrm{SG}$ see dog farm

'I saw dogs on the farm.'

Building on the discussions in the present section, the next sections (2.2.1.-2.2.2.) discuss in detail, the different positions in which a BN is grammatical. First, section 2.2.1., discusses BNs in argument positions and second, I consider nouns in predicate positions 2.2.2.

\subsubsection{BNs in argument positions}

When comparing examples from Ògè and English, BNs do not behave the same way. For languages like English, it is argued that only the category of articles turns a projection of a noun into a referential expression, which can then function as an argument of the verb. Longobardi (1994) defines articles as the natural bearer of referentiality. This description captures the article in Ògè as will become clear in section 2.3. Since nouns in Ògè can generally appear without the article, then there is a semantic difference observed in the presence versus absence of the article (the absence of the article translates to the

\footnotetext{
${ }^{4}$ Plurality in Ògè is optionally marked on the nouns. This means that a BN is ambiguous between a singular and a plural reading, in this sense, an alternative interpretation of (13b) would be 'I saw the/a dog on the farm.' I will come back to this in a later chapter.
} 
ambiguity of the NP between an indefinite and a definite reading while its presence does not translate to such ambiguity.

In DP languages, such as English and German, the category of (in)definiteness is primarily expressed by the articles as shown in the example in 14-15.

(14) a. I want*(a) bottle.

indefinite

b. I want *(the) bottle.

definite

(15) German

a. Ich brauche *(eine) Flasche. indefinite

1SG need a bottle

'I need a bottle.'

b. Ich brauche $*($ die $) \quad$ Flasche. definite

$1 \mathrm{SG}$ need the bottle

'I need the bottle.'

In English and German, articles are obligatory in the contexts of the noun Flasche 'bottle' in object position which indicate either an indefinite or a definite interpretation of the noun. On the other hand, in Ògè, nouns are optionally accompanied by the articles, even in the contexts shown for English and German above. This is shown in (16).

(16) Í dà ìgò
1SG buy bottle
'I bought a/the bottle'

In (17a), the BN akẹke 'bicycle' in object position indicates indefiniteness without an overt indefinite marker. Further to this, the utterance in (17b) is well formed in which akẹke 'bicycle' receives a definite interpretation. This is like the analysis of BNs in Yorùbà as 
presented in Ajíbóyè (2005) in which a known or a familiar referent receives a definite reading without an overt marker of definiteness.

(17) Background: Tortoise was hiding in a bush, and from his hiding place, he threw a bicycle to the main road, a girl was about to walk across the road when she saw the bicycle, she uttered the sentence in (17a).

a. Í ri akẹkẹ́

$1 \mathrm{SG}$ see bicycle

'I saw a bicycle.'

b. Akẹ̀kẹ nì Sade rì go

Bicycle REL Sade see old

'The bicycle that Sade saw is old.'

Bare subjects can also be interpreted as either indefinite or definite. In the example in (18), 'Tunde' receives a definite interpretation because it is a proper name which is classified as determinerless (Ajíbóyè 2009).

(18) a. Tunde jù ìsi

Tunde eat yam

'Tunde ate yam'

b. Bolu shìn

Bolu sleep

'Bolu is sleeping'

On the other hand, the common nouns oko-úwan 'boy' and ópu' 'dog' in subject positions (19) are ambiguous between an indefinite and a definite interpretation. 
(19) a. Ọkọ-úwan jù ìsi

male-child eat yam

'The/A boy ate the yam.'

b. Ópú sì úrun éswe

dog is inside house

'The/A dog is in the house.'

The examples in (19) show that the BNs (common nouns) in subject positions can all be interpreted as either definite or indefinite. However, the expression in (20) show that isi 'yam' in the second part of the sentence can only be interpreted as definite. This conclusion follows from the assumptions in Heusinger (2001) that the referents can be definite and specific if both speaker and hearer can identify them.

(20) Tunde jù ìsi, àmo ìsi àà yẹ

Tunde eat yam, but yam NEG sweet

'Tunde ate a/the yam, but the yam is not sweet.'

We see that the second mention of isi 'yam' in (20) shows that it is a familiar referent which is already introduced in the first part of the sentence. Like BNs in subject positions, BNs in object position can be interpreted as (in)definite, plural/singular, (non) specific. However, it is important to note that a definite plural interpretation of the $\mathrm{BN}$ is not possible because this interpretation is only available with the overt maker for plurality òtúro as shown in (5) repeated here in (21).

(21) a. òtúro ópú

PL dog

'the dogs, *dogs' 
b. Túndé dà ópú.

Tunde buy dog

'Tunde bought a dog.'

c. Túndé fệhẹ̀nópú.

1SG like dog

'I like the/a dog.'

The interpretation of the sentences in $(21 \mathrm{c})$ could be said to be a general one since it contains the verb fệhẹn 'like' and the object of the verb fệhẹn can be interpreted as generic because BNs in such contexts are usually interpreted as indefinite nonspecific. The relationship between the examples $(21 b$ and $c)$ could have the literal meaning of something like 'Tunde bought a dog because Tunde love dogs' This shows that the interpretation of óp' 'dog' as indefinite in (21b) represents new information in the discourse context. On the other hand, ópú in (20c) yields additional meaning of definite interpretation because the referent of the noun is already known in the context since the speaker already mentioned it.

\subsubsection{BNs in Predicate positions}

Stowell (1991) suggests that nouns, alongside verbs, adjectives and prepositions can function as predicative heads because they can assign theta-roles. President in (22) assigns a theme theta role to John. Likewise, úsin 'king' and olùkọ 'teacher' in (23) and tenente 'lieutenant' in (24) assign the theme role to Tunde, Jọ́ọnù and Gianni respectively. President, Tunde, Jọọnù and tenente are predicative heads and they are not as a rule accompanied by an article. 
(22) The students elected John President (of the union).

$$
\text { Ògè }
$$

a. Túndé si úsin.

Tunde is king

'Tunde is a king.'

b. Jộọ̀nù sì olùkọ́.

John is teacher

'John is a teacher.'

(24) Italian

Gianni è tenente.

John is [a] lieutenant

'John is a lieutenant.'

External arguments denote arguments in subject positions, base position is inside VP; final position of subject outside VP, while internal arguments are objects within the verb phrase (VP). The nominals in object positions (22-24) without the determiners function as predicates.

\subsubsection{Towards an analysis of the syntactic structure of nominal expressions in Ògè}

In addition to the definiteness function observed in previous sections for ikári, ikári is inherently referential unlike náà in Yorùbá as shown in (26) and Italian as shown in (27). In other words, ikári is not compatible with a proper name in isolation (25a).
a. *ikáriSadé
DEF Sade
*'the Sade' 
b. ikári Sadé ràn

DEF Sade my

'my Sade'

(26) Yorùbá

Sadé (mi) náà

Sade $(1 \mathrm{SG}+\mathrm{ACC})$ the

a' 'My Sadé too'

a" 'My very Sadé'

(27) Italian

il (mio) Gianni

the (my) Gianni

'my Gianni'

I analyze articles in Ògè as an optional element in the nominal expression because the articles are not obligatory in the nominal expression in all contexts. Unlike in English and most of the Germanic languages, articles in Ògè do not necessarily accompany the singular BNs. In Yorùbá, as mentioned in section 2.2., some scholars have analyzed the seemingly similar element to the definite article in English náà in various ways as shown in (28).

(28) a. náà is a determiner

(Bámgbósé 1974, 1971, 1982)

b. náà is a salience/specificity marker (Ajíbóyè 2005, 2009)

c. náà is an adverbial adjective

(Manfredi 1992)

In what follows, I examine the different views of the scholars on the status of náa in Yorùbá and conclude that ikári does not possess such ambiguity like náà. The first argument is that náà could be interpreted as 'the' in English (29b). The second argument follows from the fact that in some contexts, náà could be said to mark nouns in Yorùbá 
for saliency (29d). Another evidence in support of the ambiguity of náà is that in some constructions, it translates to an adverb (29c).
(29) a. Mo rí ọmọ náà
$1 \mathrm{SG}+\mathrm{NOM}$ see child the
b. = 'I saw the child'
c. = 'I saw the very child'
d. = 'I saw the child in question'

However, in Ògè, İkári does not possess such ambiguity. İkári behaves exactly like 'the' in English in the sense that it is not grammatical in the context of a $3^{\text {rd }}$ person singular pronoun (30a).

(30) Ògè
a. *Í rìi ìkári
$1 \mathrm{SG} \quad \mathrm{see}+3 \mathrm{SG} \mathrm{DEF}$
'*I saw him/her the'
INTENDED: 'I saw him/her.'
b. Í ri ìári úwan.
$1 \mathrm{SG}+\mathrm{NOM}$ see DEF child
c. = 'I saw the child.'
d. = 'I saw the child in question.'
e. $\neq$ 'I saw the very child.'

(31) Yorùbá

Mo ríi náà.

$1 \mathrm{SG}+\mathrm{NOM}$ see+3SG too/also

'I saw him/her too.'

\footnotetext{
${ }^{5}$ Just like Yorùbá, the form of the third person pronoun changes with the context. For example, the third person pronoun takes the form of the final vowel of the preceding verb. see chapter five (5) for more on the pronouns in Ògè.
} 
Based on the characteristics of BNs in Ògè as laid down above, and the status of the articles ikári and ikin, this chapter argues, therefore, for a DP projection whose head is phonologically filled with ikári and ikin. I carry out a critical analysis of the positions of occurrence of the article plus the nouns in relation to the BNs in Ògè in the subsequent sections. Most importantly, I further compare nominal expressions in Ògè with nominal expressions in articleless languages on the one hand and nominal expressions with obligatory articles on the other hand and argue that nominal phrases in Ògè project a DP. This analysis is in line with Ajíbóyè (2005) who argues that nominal expressions in Yorùbá project a DP. ${ }^{6}$ The line of reasoning here also follows the assumptions in Alexiadou et al (2007:159) that although the head of a DP projection primarily hosts the article, the structural position D is also said "to assign referentiality to its NP complement" and not the article per se."

\subsection{Analysis of the syntactic structure of nominal expressions in Ògè}

This section provides detailed answers to the following questions:

(i) Does the NP in Ògè project a DP?

(ii) Can Ògè be classified as an articleless language?

First, this section reveals that the optionality of the articles within the noun phrase in Ògè is because the articles can be absent without having any impact on the grammaticality of the nominal expression with which they appear. I claim therefore, that the assumed optionality of the articles is context sensitive. In other words, articles are not always optional within a noun phrase. In addition, I argue that the articles occupy the D head and

\footnotetext{
${ }^{6}$ Ajíbóyè (2005) argues that nominal expressions in Yorùbá project a Null D. He added that a null D marks BNs as definite while an overt D marks BNs as specific.
} 
I show that the $\mathrm{D}$ head is active and bears a feature $[\mathrm{DEF}]$ which assigns (in)definiteness to the NP.

\subsubsection{The DP -Hypothesis}

Abney (1987), provides a theoretical and an empirical argument for the idea that a functional category, the Determiner Phrase (DP), is the maximal category projected by the class of determiner elements in a nominal expression. Put in another way, the DP represents the extended, and maximal, projection of the lexical head, the noun. Subsequently, the analysis of the nominal phrase changed with Abney’s (1987) analysis in which he proposed that it is the determiner that heads the noun phrase as shown in $(32) .^{7}$

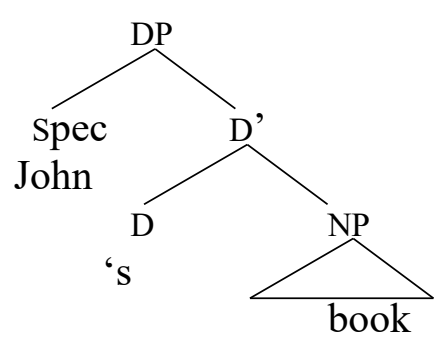

Earlier, Chomsky (1986), proposed that the X-bar notation for lexical categories which are specifier-head-complement can also be extended to functional categories. Following this spirit, the structure of clauses was analyzed as consisting of functional projections on top of the Verb Phrase (VP): Complementizer Phrase (CP) and Inflection Phrase (IP):

(33) $\left[\mathrm{CP}\left[\mathrm{C}^{\prime}\left[\mathrm{IP}\left[\mathrm{I}^{\prime}\left[\mathrm{VP} \mathrm{V}^{\prime}\right]\right]\right]\right]\right]$

Szabolcsi $(1981,1987,1994)$ proposed a parallel of CP and DP. The structure of nominal phrases contains a functional projection which is a Determiner Phrase (DP) on top of the

\footnotetext{
${ }^{7}$ The noun phrase can be headed by a functional category D just as the sentence is headed by a functional head $\mathrm{I}^{\mathrm{O}}$, as shown in (i).

(i) $[$ IP Peter $[I-s][$ vP love Mary $]$
} 
Noun Phrase (NP) (Bernstein, 1993; Stowell, 1989, 1991; Szabolcsi, 1981, 1987, 1994). It is also assumed that the head of the DP hosts determiners, which is called the DP hypothesis.

The DP hypothesis states that a functional category governs a lexical category (i.e., NP is a complement of the D-head) and this implies the linear ordering between D and NP such as restrictions of co-occurrence among English determiners like articles, the possessive morpheme (-s) and DEMs including the pronominal possessive morphemes (e.g., John's the book, see the example in (10). According to Longobardi (1994) "a nominal expression" is an argument only if it is introduced by a category D (p.620) or for nominals to function as arguments, they should have a lexically filled D category. Without those D, BNs are treated as predicate NPs, this means that D has a function of converting NPs into referential expressions, DPs.

Abney (1987:64f) contrasts lexical categories with functional ones and enumerates 5 properties which in his view characterize functional elements. Thus, according to Abney, functional elements exhibit the following properties:

- They constitute closed lexical classes.

- They are generally phonologically and morphologically dependent.

- They permit only one complement, which in general is not an argument.

- They are usually inseparable from their complement.

- Functional elements lack "descriptive content." Their semantic contribution is second order, regulating or contributing to the interpretation of their complement. They mark grammatical or relational features, rather than picking out a class of objects. (pp. 43-4)

This work shows that unlike the articles in Romance and Germanic languages, the articles in Ògè are not obligatory in the domain of the noun. Ògè can be classified as a 
language with ambiguous Bare singulars according to the classification of Longobardi $(2001)^{8}$. The main claims in this work are: (i) a DP is projected above the NP in Ògè, ii) the NP hosts additional projections (DEMP, NUMP) between the NP and the DP, (motivation for this claim is based on the co-occurrence of the article and the demonstrative and on the interpretable number feature on NUM (see chapter 5 for more details on this). iii) the possessive pronoun occupies the head of a functional phrase POSSP (POSS) in the NP. Having laid out the theoretical assumptions in this subsection, I now turn to the analysis of the nominal structure in the next subsection.

\subsubsection{A preliminary analysis of Ògè nominal expressions}

As already mentioned, I assume that the nominal phrase in Ògè, like its counterparts with BNs in their nominal expressions, projects a DP. For the status of the D head, I follow Ajíbóyè's (2009) analysis of the DP in Yorùbá. Ajíbóyè argues that the DP in Yorùbá has a null $\mathrm{D}$ that has the interpretation of the (in)definite article. I assume that the D-head in the BNs in Ògè is null and that it bears a referential feature which does not trigger a N-D movement.

As is well known that one of the motivations for a $\mathrm{N}$ to $\mathrm{D}$ movement comes from the data in Italian according to Longobardi (1994). Longobardi points out that both the determiner and the possessive do co-occur in the nominal expressions of Italian. When this happens, the order of the elements is as shown in (34a).

\footnotetext{
${ }^{8}$ Longobardi (2001) classifies languages into the follow groups: a. Languages with no bare nouns (French)

b. Languages with stricter Bare nouns (apparently the rest of Romance: Spanish, Italian...)

c. Languages with freer bare nouns (English and most of Germanic languages)

d. Languages with indefinite bare singulars (and only a definite lexical article: Icelandic, Celtic, Hebrew

e. Languages with ambiguous bare singulars (i.e articleless languages: Russian, Czech, Latin
} 
(34) Italian

a. [DP Il mio Gianni] ha finalmente telefonato.

b. *[DP Mio Gianni] ha finalmente telefonato

c. [DP Gianni mio] ha finalmente telefonato.

(the) my John has finally called

'My John has finally called'

However, Longobardi argues for the movement of the noun, from its canonical position to the $\mathrm{D}$ in surface syntax when the determiner is not in the nominal phrase, this explains why the order in (34b) is not grammatical while the order in (34c) is grammatical because of the change in word order.

As shown for Ògè in (35), this is not the case, nouns in Ògè remain in the lexical position within the NP. The example in (35a), shows the well-formedness of the cooccurrence of ikári 'the' and ràn 'my' In (35b), in the absence of ikári, the form N-Poss is well-formed while in the absence of ràn in (35c), the form D- $\mathrm{N}$ is also well-formed.

(35) a. ikári éswe ràn

DEF house my

'my specific house'

b. éswe ràn

house my

'my house'

c. ikári éswe

DEF house

'the house' 
For Ògè, I assume that the D head is occupied by the article when it is overtly realized. On the other hand, the D head is null when the article is not overtly realized. ${ }^{9}$ I propose the structure in (36) for the syntactic structure of the nominal expressions in Ògè.

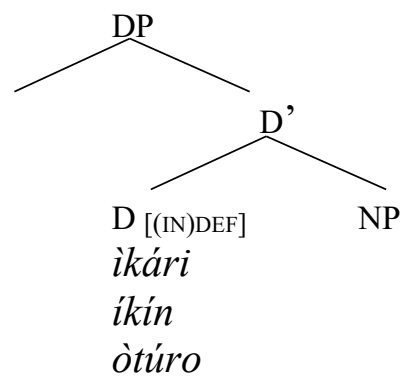

\section{A preliminary structure of the nominal expressions in Ògè Ia.}

The structure in (36) shows that definiteness is realized in one of two ways; (i) phonologically filled D-head (37a) (ii) null D-head (37b).

a. ìkári/íkín/òtúro éswe

(IN)DEF PL house

'a/the house(s)'

b. Í rì $\varnothing \quad$ éswe.

$1 \mathrm{SG}+\mathrm{NOM}$ see (IN)DEF house

'I saw the/a house.'

The elements in the prenominal position of the noun ikári/ikin/òtúro occupy the D-head in (37a) while (37b) shows that the head is null. Further evidence in support of the position of occurrence of the articles as shown in the structure in (36) comes from the

\footnotetext{
${ }^{9}$ Context plays a role in determining the overt and/covert realization of the articles in the nominal constructions of Ògè; òtúro is required in an obligatory plural definite context while ikári/ikín is required in a singular (in)definite context. Contexts with no specification for number or (in) definite reading of the noun, translates to a null D.
} 
examples in (37). The elements ikári/íkín/òtúro are in complimentary distribution which suggest that they all occupy the same position in the syntactic structure.

\begin{tabular}{clll} 
(38) a. *ikári & íkín & \multicolumn{2}{c}{ òtúro ópú } \\
DEF & INDEF & PL & dog \\
b. *òtúro & ikári íkín & ópú \\
PL & DEF & INDEF & dog \\
c. *íkín & òtúro ìkári ópú \\
INDEF & PL DEF dog
\end{tabular}

As evidenced from the interpretation of the definiteness of nouns in the presence of the article in languages, the article is generally analyzed as a head that projects its own (functional) category which is called the DP. However, the article is not obligatory in the nominal phrase of Ògè as earlier mentioned. The question arises as to what happens when the article is not realized phonologically on the D-head? To answer this question, I assume following Lyons (1999) and Longobardi (2001), that D is the locus of definiteness, this means that irrespective of the status of D (either phonologically filled or not) D is obligatorily realized to give its semantic impact in the projection of the NP. The D hosts the definite article (if it is present) which selects as its complement the lexical NP in Ògè or the NumP as shown in (39). I claim that in Ògè, the semantic-syntactic category D is the vehicle of definiteness either phonologically filled or not. In addition to this, the D performs a dual function of both (in)definiteness and number specifications (the full discussion and analysis is given in chapter five (5)) but it is enough to point it out in this chapter that the NP is dominated by the NumP and that the D selects as it compliment, the NP/NumP. 


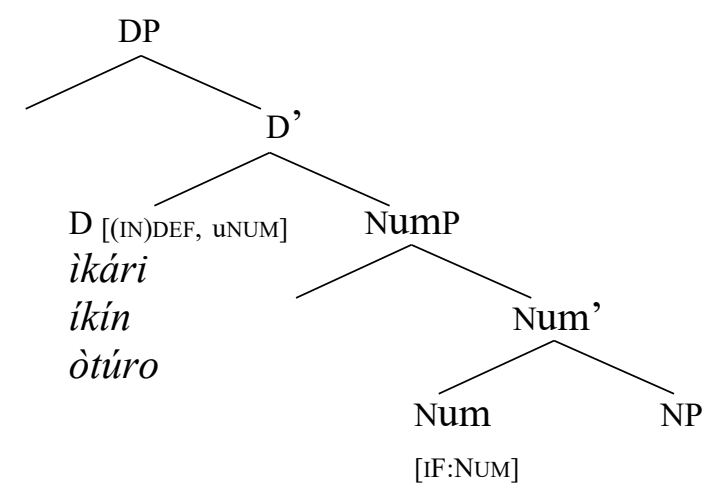

\section{A preliminary structure of the nominal expressions in Ògè} Ib.

I classify the elements ikári/ikin/òtúro as determiners that show number agreement, for instance, òtúro takes a value for a plural feature from Num while it marks a noun for definiteness. On the other hand, ikári/ikín, take a value from Num for a singular feature and mark a noun for definiteness as in ikári and indefiniteness as in ikín. Additional evidence for an additional functional projection (DEMP) between the DP and the NP comes from the grammaticality of the examples in (4 and 6), repeated here in (40). The grammaticality of the expressions show that the articles and the demonstratives do not compete for the same position in the functional projection of the NP. This is the topic of the next section

(40) a. ikári ígé/íghẹ ópú

DEF DEM dog

'that/this dog'

b. íkín ígé/íghẹe ópú

INDEF DEM dog

'that/this dog' 
c. òtúro ígé/íghẹ ópú

PL DEM dog

'those/these dog'

\subsection{Demonstratives in Ògè}

The category of the demonstrative is different from the (in)definite article which is language specific. Ògè has a two-form demonstrative system: igé 'that/those' and ighẹ 'this/these' as illustrated in (41).

(41) a. ígé úwan

DEM child

'that/those child/ren'

b. íghẹ úwan

DEM child

'this/these child/ren'

Ígé 'that' is used to refer to items close to the speaker, while ighé is used to refer to items further away from the speaker. The demonstratives in Ògè perform the same function with the demonstratives in English as will be made clear in subsequent sections. It is interesting to note that in Yorùbá, the form of the demonstratives differs when it is used deictically. The demonstratives in Yorùbá are yii 'this' and yẹn 'that.'
(42) a. ìwé yẹn
book DEM
'that book'
b. ìwé yì́
book DEM
'this book' 
$y e n$ 'that' refers to an object which is far from the speaker while yil refers to an object which is relatively close to the speaker. The demonstratives in Yorùbá can occur without the object of reference, however, when this happens, yen must be prefixed with $i$ while yil must be prefixed with $e$ as shown in (43).

(43) a. ì- yẹn

PfX- DEM

'that one'

b. è- yíi

pfx- DEM

'this one'

(44) a. yẹn

DEM

$=$ 'that'

$=$ '*that one'

b. yìí

DEM

$=$ 'this'

$=*$ 'this one'

The ungrammaticality of the examples in (44) show that the demonstratives in Yorùbá is obligatorily prefixed with $i$ or $e$ when they occur in isolation. However, it is possible to use the prefixed form of the demonstrative when it is preceded by a noun as shown in $(45)$.

(45) a. ìwé ìyẹn

book DEM

'book of that one' 
b. ìwé èyíí

book DEM

'book of this one'

iyẹn and èyíi in (45) are ambiguous between two readings i) I saw the book which belongs to a person that is within the context of the utterance of the sentence ii) the demonstrative is used to pick out the intended referent out of few possibilities. One could say iyen and èyí are used contrastively to convey referentiality. Invariably, it is possible to differentiate between the book that one saw from the book which one did not see with the use of ìyen and èyí in Yorùbá.

However, in Ògè, the forms of the demonstratives are the same in all contexts just like in English as shown in (46) and (47).

(46) a. ígé ìwé

DEM book

'that/those book'

b. íghẹ́ ìwé

DEM book

'this/those book'

(47) a. ígé

DEM

$=$ 'that $/$ those'

$=$ 'that/those one(s)'

b. íghẹ

DEM

$=$ 'this/these'

$=$ 'this/these one(s)' 
The forms of the demonstratives remain the same in all contexts in both languages (English and Ògè) unlike in Yorùbá. An observed difference however is seen in number agreement i.e., demonstratives change with respect to singular and plural this-these, thatthose in English. In Ògè, demonstratives have the same form when they are used in plural and singular contexts. In this section, I discuss the category of demonstratives in Ògè and in the following sections, I will provide answers to the following questions: i) are demonstratives in Ògè the same as articles? ii) do the demonstratives in Ògè perform the same function as the functions identified in other languages for demonstratives i.e., definiteness and referentiality? I will start my discussion with the second question.

\title{
2.4.1. Functions of the demonstratives in Ògè
}

The demonstratives can perform the function of definiteness and referentiality. I discuss these functions below.

\author{
(48) a. ígé/ighẹ úwan \\ DEM child \\ 'that/this child' \\ b. ikári úwan \\ DEF child \\ 'the child'
}

In (48a), igé performs the function of referentiality and definiteness. For instance, (48a) can be interpreted as 'I saw this child and not that one', in this case, the demonstrative is used referentially to distinguish between an object that is close or far from the speaker. This contributes to the use of igé and ighẹ as referential expressions because of their ability to refer to entities of the linguistic world. As such, it is also possible to point at the object in question. On the other hand, igé in (48a), can be interpreted as a marker of 
definiteness because it refers to this child and not your child for example, igé marks the child as definite because as it is used in (48a), it disambiguates the ambiguity of the child under discussion. In this sense, igé is inherently like the definite marker and it serves to identify the referent. In addition, igé does not describe the noun it refers to. This means, igé and ighẹ are like this and that in English, ofto and ecino in Greek, tama and tuo in Finish (Alexiadou et al. 2007) which all lack descriptive content. On the other hand, the definite article in (48b) ikári refers to a child and not just a child that is not known. İkári also performs the referentiality function, İkári can refer to a previously mentioned noun. Unlike İkári, igé cannot refer to generic nouns. ígé does not have a generic reading. Hence, igé is directly referential, its interpretation depends on the context of usage. According to Lyons (1999:637), deictic categories relate the linguistic entities that encode them to the spatio-temporal, that is the extra-linguistic context. Another function performed by the demonstrative in Ògè is indexical. Both igé and ighẹ can make contrast among referents (Hawkins 1978; Lyons 1999). In (48a), the demonstratives are used to locate the referent with the reference to some point in the non-linguist context. For instance, íghẹ úwan 'this child' denotes a child that is found close to the speaker than does ígé úwan 'that child'. ${ }^{10}$

\subsubsection{Syntactic Position of the Demonstratives in Ògè}

In section 2.3., I showed that the articles occupy the D-head (36) and that they occur in the prenominal position. The demonstratives also occur in the prenominal position. Based on the position of occurrence of the demonstrative in the nominal expression with respect

\footnotetext{
10 The deitic feature of demonstratives is in general interpreted in two ways; either it is encoded in the opposition [+/- proximal] or [+/- distal], with the speaker as the direct anchoring (Alexiadou et al:2007).
} 
to the (in)definite article, one could assume that the demonstrative also occupies the same position as the article in Ògè.

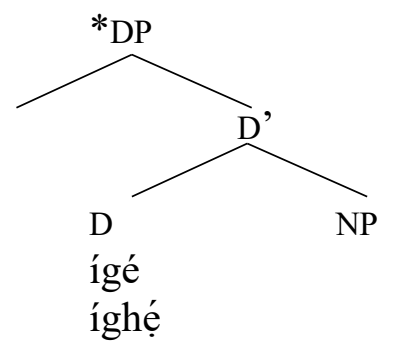

However, the position postulated for the occurrence of the demonstrative in (49) needs to be investigated further in the sense that, one needs to ask the question if both the demonstrative and the article can co-occur in the noun phrase in Ògè just like what we have in other languages like Spanish, Greek and Hungarian, This is not possible in English for instance:

(50) a. *this the dog

b. *the that dog

Meanwhile, the demonstrative and the articles do not compete for the same position in Ògè. They do in Greek and Hungarian as shown below.

(51) Greek
a. Afto to vivlio
this the book
'this book'

\section{Hungarian}

b. ez a haz

this the house

'this book'

Similarly, in Ògè (52) and Yorùbá (54), both elements are grammatical in the nominal expressions, but with a different order from Greek and Hungarian. 
(52) Ògè
a. ìári ígé ópú
DEF DEM dog
'that dog'
b. ìkári íghẹe ópú
DEF DEM dog
'this dog'

(53) a. *ígé ikári ópú

DEM DEF dog

'that dog'
b. *íghẹe ikári ópú
DEM DEF dog
'this dog'

(54) Yorùbá
a. ajá yií náà
dog DEM DEF
$=$ 'this dog'
$=$ 'this dog too/also'
$=$ 'this particular dog'
b. ajá yẹn náà
dog DEM DEF
$=$ 'that dog'
$=$ 'that dog too/also'
$=$ 'that particular dog'

The paradigm in (54) for Yorùbá shows that both the demonstrative and the article (if we agree that náà is a determiner as argued in Awobùlúyì 1978) can co-occur. When this happens, the reading is ambiguous between a simple $\mathrm{N}+$ DEM/DEF and an emphatic 
reading. The relevant point for my analysis though is the fact that the co-occurrence of both elements (articles+demonstratives) yield a grammatical string. In Ògè, the grammaticality of (52) also indicates that the linear order DEF+ DEM is well-formed. However, the ungrammaticality of (53) shows a strict order of DEF + DEM and not DEM + DEF. Subsequently, apart from the empirical evidence of the grammaticality of the cooccurrence of the demonstratives and the articles in languages, I discuss further evidence in support of the different layers for the demonstratives and the articles in Ògè.

Since a single node in a tree can only accommodate one element at a time, it follows that a noun phrase could have only one determiner in D. The nominal expressions in Ògè hosts an additional functional projection between the DP and the NP. The motivation for this claim is based on the co-occurrence of the article and the demonstrative among other things. Based on the position of the demonstrative in Ògè which is located below the article, I propose that one further functional category, labelled DemP, should further be embedded into the DP structure.

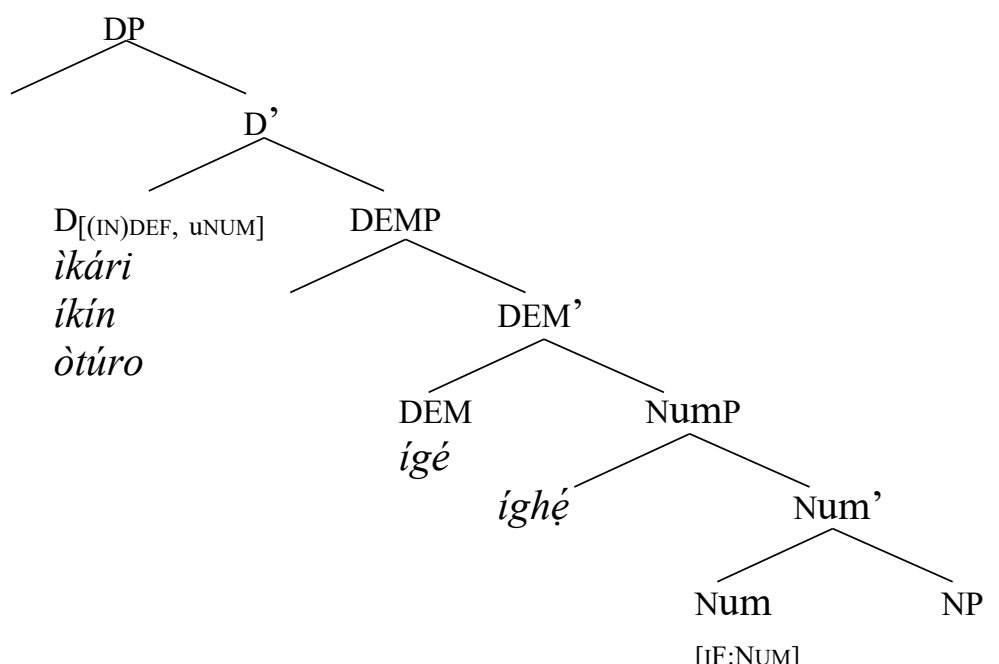

Revised version 1. 
The linear order of the elements in the nominal expressions show that there is no motivation for a N-D movement as shown and argued in section 2.3.2. However, as illustrated in (7), Ògè makes use of a specificity marker which occurs at the final position of the nominal expression, because of the linear order of the elements in the nominal expression in the overt realization of this marker, there arises the need to posit an additional projection in the nominal structure of Ògè. This is the focus of the next section.

\subsection{Additional elements in the DP of Ògè}

As hinted in section 2.1., Ògè makes use of a specificity marker in its nominal expressions. As I show later in this section, Ògè, just as in related languages Yorùbá and Gungbe, makes use of a phrasal movement rather than a N-D movement in its functional spine. First, I show that the specificity morpheme projects a specificity phrase (SpP) just as has been proposed for Mauritian Creole (Guillemin 2009, 2011, 2014). Second, I assume that the Sp bears a strong specificity feature which attracts the movement of the DP to [Spec Sp]. To support the phrasal movement proposed for the NP in Ògè, I show that a modified NP with an attributive modifier can move to [Spec Sp] or to [Spec PossP] in expressions as shown in (56).

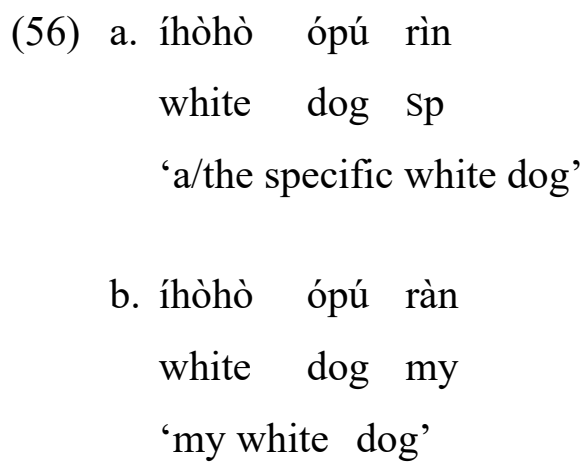




$$
\begin{aligned}
& \text { c. íhòhò ópú ràn rìn } \\
& \text { white dog my } \mathrm{sp} \\
& \text { 'my specific white dog' }
\end{aligned}
$$

To begin with, section 2.5.1. shows how a nominal expression is interpreted as specific with or without the marker for specificity while section 2.5.2. is on the analysis assumed for the phrasal movement in Ògè.

\subsubsection{The specificity marker in Ògè}

The specificity marker rin occurs in post-nominal position in order to mark a noun for specificity, the example in (57) shows the occurrence of rin with BNs.

$$
\begin{aligned}
& \text { a. ópú rìn } \\
& \text { dog } \mathrm{Sp} \\
& \text { 'the/a specific dog' } \\
& \text { b. ẹnẹ rìn } \\
& \text { person/people sp } \\
& \text { 'the/a specific person/people' }
\end{aligned}
$$

According to Ajíbóyè (2005), languages like Yorùbá, English, Turkish and Gungbe can all overtly mark indefinite nouns for specificity. As Fodor and Sag (1982) observe, English indefinites are ambiguous between specific and non-specific readings. This is further corroborated in Ajíbóyè (2005) when he notes that indefinite nouns in English may be specific without being morphological marked for specificity.

(58) a. I want a book

b. I would like to buy a car

\section{specific/non-specific \\ specific/non-specific}

(Ajíbóyè 2005:1990) 
Following Enç (1991) and Von Heusinger (2002), Ajíbóyè shows that specificity is overtly marked in English with markers like certain, and specific on indefinite nouns as shown in (59).
a. I want a certain book
specific
b. I like to watch a particular movie

\section{specific}

(Ajíbóyè 2005:191)

Yorùbá on the other hand marks specificity with kan and náà (Ajíbóyè 2005, 2009). Using context to disambiguate the (in)definiteness of BNs in Yorùbá, Ajíbóyè shows that a BN in a context with an indefinite reading as shown in (60) can be interpreted as non-specific.
(60) Jíbọ́lá ń wá àga tí yóò jókò lé indefinite non specific Jíbọ́lá PROG.search chair COMP FUT sit on
'Jíbọ́lá was looking for a chair to sit on'

(Ajíbóyè 2005:189)

In (60), àga 'chair' is interpreted as indefinite and non-specific without the overt marking for specificity. However, Ajíbóyè notes that kan can overtly mark an indefinite noun for specificity as illustrated in (61a).

(61) Background: When Jíbọlá is tired, there is a particular chair in his house that he sits on.

a. Jíbọ́lá ń wá àga kan tí ó maá ń jókò lé

indefinite specific

Jíbọ́lá PROG search chair SPF COMP3SG ASP ASP sit on

'Jíbọ́lá is looking for a certain chair that he sits on' 
b. Jíbọ́lá rí àga tí ó ń wá ni igun yàrá...

definite specific

Jíbọ́lá see chair COMP 3SG ASP search LOC corner room

'Jíbọ́lá saw the chair he is looking for at the corner of the room...'

(Ajíbóyè 2005:189)

In (61), àga 'chair' is interpreted as definite and thereby qualifies as specific without the overt realization of the specificity marker kan. The example in (61a), shows that kan marks an indefinite noun as specific. This is because, Jíbọlá has a chair in mind that she was looking for. Àga 'chair' as used in (61a) is unambiguously interpreted as specific because of the presence of the specificity marker kan.

For Yorùbá, Ajíbóyè argues that only indefinite BNs are marked for specificity while definite BNs are not overtly marked for specificity. Specificity marking in Yorùbá and in English is similar on the one hand because both languages require no overt specificity marking for definite nouns. They differ on the other hand because specificity marking on indefinite nouns is not optional in Yorùbá as it is in English (59a). The phenomenon in Ògè differs from what we see in Yorùbá and in English above because the marking of specificity with rin on a definite noun is optional while an indefinite noun could be marked for specificity with the specificity marker, rin. As mentioned in section 2.3., ikin marks a noun for indefiniteness, invariably, ikin is used to refer to an entity that may/or may not be known to the speaker. The context in (62a) explains the concept of specificity in Ògè. 
(62) a. Background: A pregnant woman was fetching firewood in the bush, suddenly, she fell and heard a voice. The voice greeted her by saying 'sorry my mother'. The pregnant woman stood up and started searching for the person who greeted her. After a fruitless search, she uttered the sentence in $(62 \mathrm{~b}) .{ }^{11}$

b. Ọ̀ran n’ẹ í gwa mi rìn, n'aà rí rìn indefinite specific

$2 \mathrm{SG}+\mathrm{EMPH}$ COMP+RP ASP greet $1 \mathrm{SG}+\mathrm{ACC}$ SP, COMP+NEG see $\mathrm{SP} \ldots$

'You who (particular person) greeted me, that I did not see...'

The person that greeted the speaker is unknown to the speaker, in a context such as (62), the referent is indefinite but specific because of the overt realization of rin. I explain further with the examples in (63) in which $i$ kin behaves the same way as its counterpart in English, for instance, ikín in Ògè can mark nouns as specific without the specificity marker.

(63) a. akẹ̀kẹ a/the bicycle' indefinite, non-specific or definite, specific b. íkín akẹ̀kẹ́ 'a bicycle' indefinite, non-specific or indefinite, specific c. íkín akệkẹ rìn 'a specific bicycle' indefinite, specific

As shown in the paradigm in (63), akẹkẹ 'bicycle' is ambiguous between two readings: in isolation, akẹké could be interpreted as definite or indefinite, when the noun is interpreted as indefinite without an overt marking for indefiniteness, then the noun is automatically interpreted as non-specific. On the other hand, if indefiniteness is overtly marked on akẹké (63b), just like in English as shown earlier in (59), the noun is interpreted either as specific or non-specific. In (63c), with rin, the nominal phrase is interpreted as indefinite, specific. I illustrate this further with the examples in (64).

\footnotetext{
${ }^{11}$ This context is taken from an unpublished folktale that were collected, collated and translated into English from Ògè.
} 
(64) a. Í rì akẹ̀kẹ́

indefinite nonspecific/indefinite specific

$1 \mathrm{SG}$ see bicycle

'I saw a bicycle.'

b. Í rì íkín akệkẹ́ indefinite nonspecific/indefinite specific $1 \mathrm{SG}$ see INDEF bicycle

'I saw a bicycle.'

c. Í rì íkín akẹ̀kẹ́ rìn indefinite specific

$1 \mathrm{SG}$ see INDEF bicycle SP

'I saw a specific bicycle'

The BN in (64a), could be interpreted as definite or indefinite. In such context, akẹkẹ̣ 'bicycle' is ambiguous between a specific and non-specific reading. In (64b), akẹ̀kẹ is interpreted as indefinite and non-specific on the one hand and indefinite and specific on the other hand. In (64c), in addition to the indefinite marker, rin is overt. Here, with the overt realization of the specificity marker, the reading one gets is unambiguously indefinite plus a specific interpretation. In addition to the marking of indefinite nouns for specificity in Ògè, definite nouns are also marked for specificity with or without rìn.
a. Í rì ìkári akẹ̀kẹ́
definite specific
$1 \mathrm{SG}$ see DEF bicycle

'I saw the bicycle'
b. Í rì ìkári akẹ̀kẹ́ rìn definite specific
$1 \mathrm{SG}$ see DEF bicycle SP

'I saw the specific bicycle'

The BN akẹkẹe is interpreted as definite specific in (65a), without the overt marking for specificity, this shows that Ògè covertly marks a definite noun for specificity. It is also 
important to note that rin is grammatical in the context of the definite article as shown in (65b). Thus in Ògè, it is possible to i) interpret a BN in two ways with regards to (in)definiteness and specificity; indefinite, non-specific or indefinite, specific and definite, specific ii) interpret an overtly marked indefinite noun as specific with rìn iii) interpret an overtly marked definite noun as specific with rin iv) interpret an overtly marked definite noun as specific without rin.

In summary, the study of specificity marking on nouns in Ògè in comparison with two other languages (Yorùbá and English) reveals that Yorùbá marks indefinite nouns overtly for specificity with kan, Ògè uses rìn while English does not have a designated marker for this purpose. ${ }^{12}$ In addition, specificity is not marked in Ògè just like English when the indefinite article is overt as shown in (66b).
a. I want a book
specific/ nonspecific
b. íkín akẹkẹe
indefinite nonspecific/ indefinite specific

In Ògè, if the definite article is overt, the noun is unambiguously interpreted as specific just like in English.
a. ìkári akẹkệ
definite specific
b. the book
definite specific

Ògè overtly marks a definite noun for specificity, as shown in (65a \& 67b). This is quite different from the assumptions in Ihsane \& Puskas (2001). Both authors argue that definiteness and specificity are two distinct properties and that a definite DP is not necessarily specific which makes the two properties to be independent of one another.

\footnotetext{
12 The meaning of the statement that English does not have a designated marker for this purpose (as in designated marker of specificity) is that, as shown in (59), we see that particular or certain are used for this purpose and as is well known that both elements are found in other contexts in which they perform other functions aside the marking of specificity. In Ògè, rìn is restricted to the context in which it is used to mark specificity on the noun, it is not used in any other context to perform other functions.
} 
This work agrees with the assumptions that the two notions are distinct properties (as will be made known in the next section, both elements project distinct heads; DP and SpP) but I disagree with the assumption that a definite DP is not necessarily specific. ${ }^{13}$

Table 2.1: Specificity marking variations in Ògè, Yorùbá and English.

\begin{tabular}{|c|c|c|c|c|}
\hline & Specific & Non-specific & Definite & Indefinite \\
\hline Ògè & $\begin{array}{l}\text { Bare Noun } \\
\mathrm{N}+\mathrm{SP} \\
\mathrm{DEF}+\mathrm{N} \\
\mathrm{DEF}+\mathrm{N}+\mathrm{SP} \\
\mathrm{INDEF}+\mathrm{N} \\
\mathrm{INDEF}+\mathrm{N}+\mathrm{SP}\end{array}$ & $\begin{array}{l}\text { Bare Noun } \\
\text { INDEF + N }\end{array}$ & $\begin{array}{l}\text { Bare Noun } \\
\mathrm{DEF}+\mathrm{N}\end{array}$ & $\begin{array}{l}\text { Bare Noun } \\
\text { INDEF }+\mathrm{N}\end{array}$ \\
\hline Yorùbá & $\begin{array}{l}\text { Bare Noun } \\
\mathrm{N}+\mathrm{SP}\end{array}$ & Bare Noun & Bare Noun & Bare Noun \\
\hline English & $\begin{array}{l}\text { INDEF + N } \\
\text { DEF + N } \\
\text { DEF +ADJ+ N } \\
\text { INDEF + ADJ + N }\end{array}$ & INDEF + N & $\mathrm{DEF}+\mathrm{N}$ & INDEF + N \\
\hline
\end{tabular}

As exemplified in table 2.1. above, the criteria for marking specificity overlap with the criteria for non-specificity in some way in the three languages. For the sake of clarity, I will only expatiate more on Ògè. First, we see that the indefinite article may mark a noun as either specific or nonspecific (this is context sensitive as shown in 61 and 62). Second, a BN could also be interpreted as specific without the overt marking for specificity, this is also context sensitive, for instance, if the BN refers to a noun in a context where it refers to a familiar element, then it is interpreted as indefinite specific in which the indefinite refers to a BN with an indefinite interpretation but with a specific construal.

\footnotetext{
${ }^{13}$ I argue instead that the definite, specific interpretation of an overtly marked noun with the definite article depends heavily on pragmatics as shown in Ajíbóyè (2005) and as shown in this work, in which a BN that has a definite interpretation is necessarily interpreted as specific.
} 


\subsubsection{Syntactic analysis of rin in the functional projection of the NP}

The position of occurrence of rin in the nominal expression (post-nominal) is not peculiar to Ògè. The examples in (68-70) show that the specificity marker in some related languages also occur in the postnominal positions.

(68) Yorùbá

Mo rí eku kan

$1 \mathrm{SG}$ see rat $\mathbf{S P F}$

'I saw certain a rat'

(Ajíbóyè 2009:49)

(69) Gungbe

távò ló

table DET

'the (specific) table'

(Aboh 1998:1)

(70) Mauritian creole

$\mathrm{Mo} /$ to/ so/ nu loto la

1. SG.Poss 2.SG.Poss 3.SG.Poss 1.PL.Poss car $\mathbf{s p}$

'That car of mine/yours/his/hers/ours' (Guillemin 2011:268)

As mentioned in section 2.1., since the analysis of the phrasal movement adopted in this work is like the one proposed for Gungbe and MC, I will briefly discuss these two analyses before I move to the analysis of the specificity marker in Ògè. ${ }^{14}$

Aboh (1998) analyzed the specificity marker lo in Gungbe (Gbe languages) as the manifestation of the category 'Determiner'. Aboh assumes that D hosts the specificity marker and that it expresses the feature [+/- specificity]. Following Koopman (1993) and Kinyalolo (1995), Aboh argues that the order that we see in example (69) is derived by assuming that the NP-complement is attracted to [spec DP] where it is licensed for feature checking. Further motivation for such NP-movement comes from the general assumption that the functional category $\mathrm{D}$ is an 'Infl-like' or 'comp-like' element of the nominal

\footnotetext{
${ }^{14}$ Ajíbóyè (2009) argued for an adjunction analysis for the specificity marker in Yorùbá. However, rìn in this work is taken to be the head of a functional projection SpP just like la in MC and $l b$ in Gungbe.
} 
system, in the sense that it is the anchorage of certain nominal features that are licensed through spec-head relationship or checking mechanism in Chomsky's (1995) terminology. For Aboh, the feature [+specific] is a property of $\mathrm{D}$, therefore, the $[+$ specific $]$ D must be in a spec-head relation with a [+specific $]$ NP and a [+specific $]$ NP must be in spec-head relation with a [+specific] D, p.7. Following this line of arguments, Aboh proposed cyclic movement of the NP-complements to the specifier position of Num and then $\mathrm{D}$ in order to be licensed for the features [+/-plural] and [+/- specific] as represented in $(71)$.

(71) $\left[\mathrm{DP} \mathrm{NP}_{\mathrm{i}}\left[\mathrm{D}^{\mathrm{o}} l l^{\prime} \quad\left[\mathrm{NumP} \mathrm{t}^{\prime}{ }_{\mathrm{i}} \ldots .\left[\mathrm{Num}^{\mathrm{o}} l \dot{\varepsilon}^{\prime} \ldots . . .\left[\mathrm{NP} . . \mathrm{t}_{\mathrm{j} . .}.\right]\right]\right]\right]\right]$

(Aboh 1998:8)

Like the analysis proposed in Aboh (1998) for the specificity marker ló in Gungbe, Guillemin (2011) proposed a phrasal movement to the [Spec SpP]. Guillemin argues that the specificity phrase (SpP) is the topmost projection in the noun phrase and that SpP bears a strong specificity feature which forces the phrasal movement of its complement to [Spec Sp]. Like the assumptions in Ihsane and Puskas (2001) as noted in section 2.5.1., Guillemin is of the view that both definiteness and specificity are distinct universal categories of meaning which lies in the notions of denotation versus reference. Guillemin takes the specificity feature to be associated with both definite in the sense of Pesetsky (1987); Ihsane \& Pukas (2001); von Heusinger (2002) and indefinites (presupposition of existence).

Following the assumptions in Aboh (1998) and Gullemin $(2009,2011,2014)$ on the notion of a 'specificity feature' in D for Aboh and in Sp for Gullemin, I propose that the DP in Ògè is dominated by the projection SpP whose head bears a strong specificity 
feature. I further propose that just like the linear order that we see in Gungbe and MC (postposition of the specificity marker), in Ògè, the strong specificity feature in $\mathrm{Sp}$ triggers the movement of its complement to the [Spec Sp] for feature checking, section 2.5.2.1. discusses this in detail.

\subsubsection{Rìn, an instance of the specificity head (Sp)}

As shown in section 2.5.1., the specificity marker rin is not necessarily overt in the specificity interpretation of the noun in the following expressions: (i) BNs interpreted as definite (ii) overt realization of ikári/íkin/òtúro. On the other hand, the overt realization of rin translates to the obligatory interpretation of the noun as specific. The examples in (72) show that the noun is specific (without rin) as shown earlier in (63a, b) and (67a) while the example in (73) shows that rin occurs to the right of the noun phrase in order to mark the noun for specificity.

(72)

a. akẹ̀kẹ

(in)definite, specific

bicycle

'a/the specific bicycle'

b. íkín akẹ̀kẹ

indefinite, specific

INDEF bicycle

'a specific bicycle'

c. ìkári akệkẹ́

definite, specific

DEF bicycle

'the specific bicycle' 
d. òtúro akẹ̀kẹ́

definite specific

PL bicycle

'the specific bicycles'

(73)

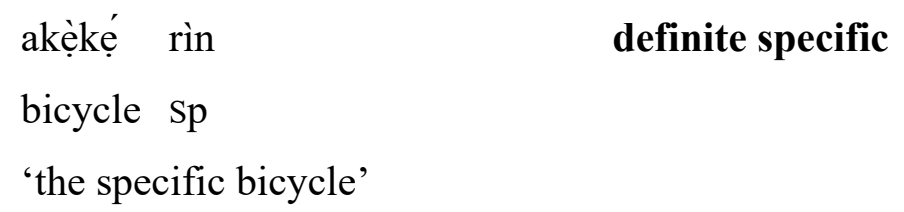

For the syntactic analysis of rin, I propose that the projection of the DP is dominated by the specificity phrase (SpP) and that the Sp bears a strong specificity features which triggers the movement of the DP to [Spec Sp] as represented on the tree in (74).

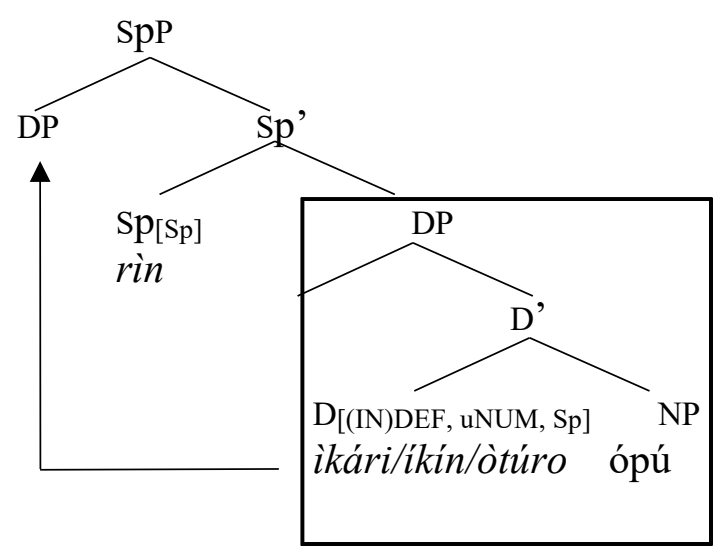

Following this line of arguments, the question arises as to what happens to the noun in the case of a specific interpretations of BNs or the specific interpretations of the string (IN)DEF $+\mathrm{N}$ ? For this analysis, I assume that the D bears a weak specificity feature which is not capable of moving its complement to the [Spec DP].

In the absence of rin as shown in the paradigm in (73), the SpP does not project. Based on the specificity interpretation of the noun in the examples in (73), this work assumes that $\mathrm{D}$ bears a weak specificity feature which does not trigger the movement of its complement to [Spec DP] as illustrated on the tree structure in (75). 
(75)

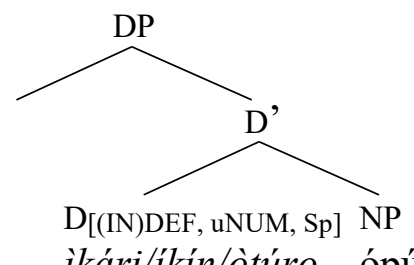

ikári/íkín/òtúro ópú

This assumption follows the well-established facts on strong and weak features of specificity in the literature (Groenendijk \& Stokhoff, 1981 and Ludlow \& Neale, 1993 among others).

\subsubsection{Evidence in support of phrasal movement}

In section 2.5.2.1., we saw an instance of the movement of the DP to the [Spec Sp]. In this section, I give further evidence to show that the movement that we see in (72) is indeed a phrasal movement in all contexts (there are no cases of a N-D movement in the DP of Ògè). The first evidence is the occurrence of a nominal attributive modifier with the noun as shown in (76a) and the second example is given in (76b) in which the possessive pronoun occurs with the noun.
a. íhòhòópú
b. ópú ràn
white dog
dog my
'a/the white dog'
'my dog'

(77)
a. íhòhò ópú ràn
b. íhòhò ópú ràn rìn
white dog my
white dog my sp
'my white dog'
my specific white dog'

(78) a. ikári/íkin íhòhò ópú ràn rìn

b. òtúro íhòhòópú ràn rìn

(IN)DEF white dog my sp

PL whitedog my $\mathrm{sp}$

'my specific white dog'

'my specific white dogs' 
The paradigm in (76-78) supports the assumption of phrasal movement in (72) in two ways (i), the attributive modifier occurs in a prenominal position as shown in (76-77) which supports the fact that $\mathrm{N}$ moves to $\mathrm{Sp}$ along with its modifier (ii), both elements (modifier and the noun) occur in a prenominal position to the possessive pronoun. These observations led us to postulate a Possessive phrase [PossP] and assume a feature [Poss] on Poss which attracts the movement of the NP to its specifier for the purpose of feature checking. This assumption further led to the order that we see in syntax in (79).

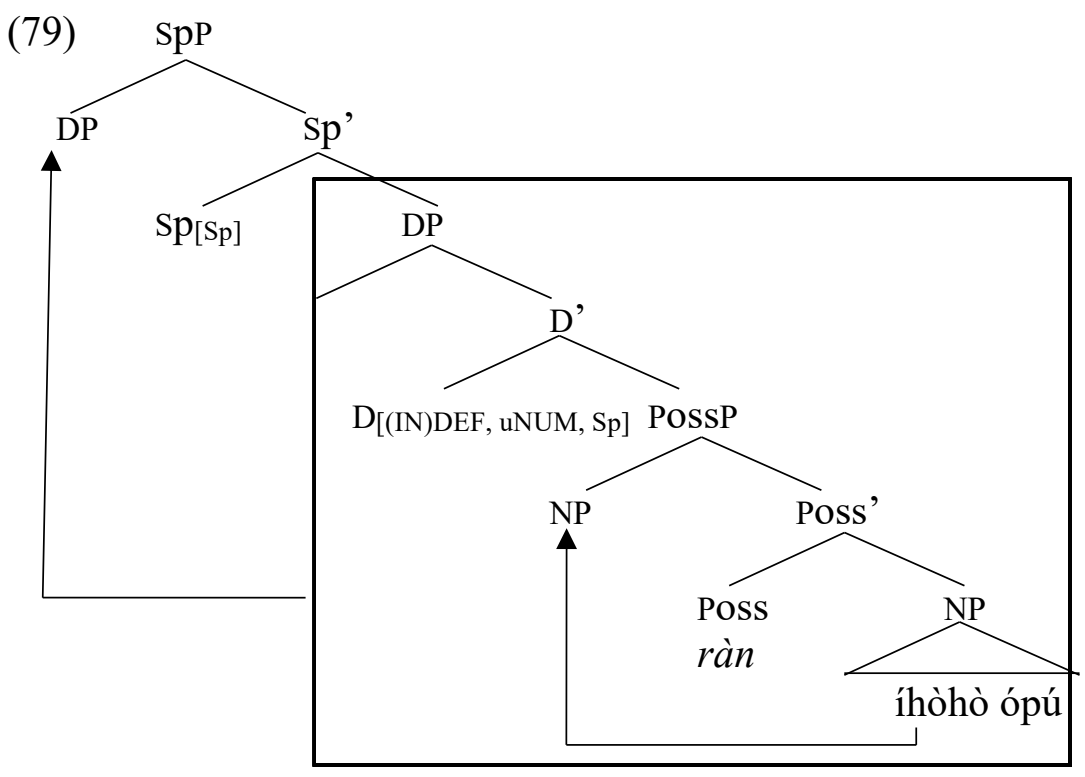

I take possessives to be a functional projection that projects its own category. The first step of the phrasal movement derives the form in (77a), while the second step derives the order in (77b).

\subsection{Summary}

In this chapter, I have provided an analysis of the structure of the nominal expressions in Ògè. First, the chapter argues that the noun phrase (NP) in Ògè is dominated by the projection of the determiner phrase (DP) because of two reasons (i), the articles in Ògè 
are not always optional i.e., they are required in some contexts which are obligatory (in)definite singular interpretation of the noun in the case ikári and ikín and obligatory definite plural interpretation of the noun as shown by the overt realization of otúro. (ii), obligatory interpretation of the noun as (in)definite. This chapter shows that the D performs a dual function of definiteness and number interpretation. The chapter further reveals that the Number phrase (NumP) is projected between the DP and the NP in which the Num bears an interpretable number feature [if: Num] which values the uninterpretable number feature on D (this analysis is given in full in chapter 5 of the dissertation). Based on the grammaticality of cooccurrence of the article and the demonstratives, an additional functional projection which is the demonstrative phrase (DEMP) is projected between the DP and the NP. As shown by the illustrations of the BNs and the order of the elements in the nominal expressions of Ògè, at first sight, there seems to be no need for the movement of the elements to DP unlike it has been proposed for other languages, i.e., $\mathrm{N}$ to D movement in Italian, Phrasal movement in Yorùbá, Gungbe and Mauritian Creole among others. However, a closer look into more elements, the possessive pronoun ràn, specificity marker rìn and the attributive modifiers shows that Ògè makes use of phrasal movement rather than a $\mathrm{N}$ to $\mathrm{D}$ movement. In addition, I propose a specificity feature on two distinct heads in the nominal expressions which are the strong specificity feature on the specificity phrase (SpP) and the weak specificity feature on the determiner phrase (DP). 


\section{Chapter 3: Internal syntax of Nominal Attributive Modifiers (NAMs) in Ògè}

\subsection{Introduction}

The aim of this chapter is to discuss adnominal modifiers in Ògè. Cinque (2010) claims that adnominal modifiers are of two-sources: a direct modification and an indirect modification source. In the process of describing the two forms of adnominal modifiers in Ògè, I observed that both forms are in complementary distribution: attributive forms are restricted to attributive positions while predicative forms are restricted to predicative expressions as shown in $(1 \mathrm{a}, \mathrm{b})$. The example in (1c) shows that the attributive form ígogo 'old' is not grammatical in a predicative position, it is only grammatical in an attributive position (1a). The form in (1b), go 'old' is the predicative form which has a restricted distribution in the predicative position.

(1)a. ígé ígogoópú

DEM old dog

'that old dog'

b. Ígé ópú go.

DEM dog be. old

'That dog is old.'

c. *ígé ópú ígogo

Int: the dog is old

For Ògè in this chapter, I show three important facts about the lexical category 'adjective' (i) there are no adjectives in Ògè (ii) attributive forms are nominal, derived from the predicative form, hence attributive forms are called Nominal Attributive Modifiers (NAMs) in this dissertation (iii) the predicative form is a stative verb. The next section (3.2.) discusses the crosslinguistic view of predicative and attributive adjectives in some 
selected languages (Russian, SerBoCroatian and German) in Europe. Adjectives in the three languages have two forms which are like the forms that we see in (1), these are referred to as Long and Short forms (LFs and SFs) of adjectives. The aim of the section is to show that, the languages possess both predicative and attributive adjectives but that the discrepancies that we see in the appearance of the two forms (LFS and SFs) are owing to independent parameters (agreement and definiteness) as will be discussed in detail in the next section. The chapter provides answers to the following research questions:

(i) Are adjectives universal? Is 'adjective' as a lexical category present in Ògè?

(ii) What cross-linguistic generalizations can be drawn about adjectives as a category?

(iii) Why are predicative and attributive modifiers structurally and categorically different in Ògè?

\subsection{Attributive versus Predicative adjectives: A cross-linguistic perspective}

This section discusses the case of three languages which overtly distinguish between the predicative and attributive forms of adnominal modifiers. The modifiers in the selected languages are called Long and Short forms (LFs and SFs) of adjectives. Section 3.2.1. discusses the case of Russian and the characteristics of the two forms of adjectives. The two forms of adjectives in some languages are associated with (in)definiteness, subsection 3.2.2. gives an overview of such adjectives in SerBoCroatian while Subsection 3.2.3. discusses the different positions of occurrence of the two forms of adjectives in German.

\subsubsection{The case of Russian}

Adjectives in Russian have a regular paradigm which are the Long Form (LF) and the Short Form (SF). Both forms of adjectives are grammatical in a predicative position (2a) while only the LF is grammatical in the adnominal position as shown in (2b). 
(2)a. Dom nov/novyi

House:nom new:nom (SF/LF)

'The house is new.'

b. novyi/*nov dom...

new:nom $(\mathrm{LF} / * \mathrm{SF})$ house:nom

'The new house...'

The major difference between the LF and the SF has to do with agreement in Case; LFs in attributive position must agree with the head noun in Case as shown in (2b). SFs are not grammatical in attributive positions because they do not possess the morphosyntactic form for case agreement Corbett (2004). Long forms behave in a similar way as nouns in Russian because nouns also inflect for case. On the other hand, SFs do not distinguish case just like verbs in Russian. ${ }^{15}$ According to (Corbett 2004), adjectives form a large class of lexical category in Russian because of the characteristics that adjectives in Russian exhibit among which are: First, Russian has a synthetic comparative, formed productively with a suffix, thus, novyi 'new', novee 'newer'. Two, derivations of nouns which makes use of suffix -ost to derive abstract nouns from adjectives staryj 'old' - starost 'old age'. Three, derivations of verbs - it is possible to derive staret 'grow old' from staryj 'old'. The class of adjectives is typologically one of the most diverse classes due to the ability of adjectives to exhibit both nominal and verbal features to a different extent in different languages (see Dixon 2004). LFs are analyzed as proper adjectives in Russian

\footnotetext{
${ }^{15}$ A comprehensive analysis of the syntax of LFs and SFs is carried out by Halle and Matushanky (2006); Babby (2010); Borik (2014). Borik, differentiates between three types of adjectival structures in Russian: short forms, simple long forms and complex long forms. One important way in which the analysis of the adjectives in Russian is relevant for this work is that adjectives in Russian are of different morphological forms which correspond to different syntactic positions with different semantics.
} 
because they can appear in canonical adjectival positions. i.e., both as nominal modifiers and in predicative positions, as shown in (2a).

\subsubsection{Bosnian/Croatian/Serbian (BCS)}

This section discusses the above-mentioned languages that are sometimes refer to as SerBoCroatian languages in the sense of Aljovic (2010). BCS has SFs that are inflectionally different from the LFs. Adjectives in BCS are distinct from their counterparts in Russian in the sense that the LF cannot be used predicatively, it has a restricted distribution to the attributive position. Take the SF and LF of poznat 'famous' in (3 and 4) for example, the example in (4) with the SF of the adjective is grammatical (attributive and predicative positions) while the LF in (3b) is not grammatical in a predicative position.

\section{Long Form}

(3)a. Poznati pjesnik

Famous.LF poet

'a/the famous poet'

b. *ovaj pjesnik je poznati

This poet is famous.LF

Int: 'This poet is famous.'

\section{Short Form}

(4)a. ovaj pjesnik je poznat.

This poet is famous.SF

'This poet is famous.'

b. Poznat pjesnik

Famous.SF poet

'a famous poet'

(Talic 2017:197) 
Adjectives in BCS occur with an inflection that is associated with the structure of the noun phrase of which they are part; Poznati 'famous' is associated with the (in)definite interpretation of the noun phrase as the gloss in (3a) shows while Poznat 'famous' as shown in (4b) occurs in a noun phrase with an indefinite interpretation.

Aljović (2010) argues that the attributive use of LFs and SFs differs with respect to referential interpretation of the noun phrase hosting the relevant adjectival form. Depending on the form of the adjective involved, the noun phrase in BCS could be interpreted as specific when it has the LF form (5b) while the non-specific interpretation of the noun phrase is associated with the occurrence of the SF (5a).

(5)a. (jedan) plav kisobran

(one) blue-SF umbrella

'a blue umbrella'

b. plav-i: kisobran

blue-LF umbrella

'the blue umbrella'

The example in (5a) with the SF of adjective is interpreted as indefinite hence non-specific while the noun phrase in $(5 b)$ with the LF form of adjective is interpreted as definite specific. In addition, LFs in BCS can stack and there is a restriction on the order of stacked adjectives, take for instance the example in (6) as illustrated in Aljovic (2010:41).

(6)

a. visoki-i

debel-i

zid

high-LONG (NOM-SG. M) thick - LONG (NOM-SG. M) wall

'The thick high wall'

b. ??debeli visoki zid

(Aljović, 2010:41) 
The example in (6b) is not grammatical because the order in (6a) is altered. However, Aljović notes that SFs do not follow such ordering restrictions rather, SFs are coordinated with a conjunction and therefore SFs can occur in any order in the noun phrase as shown in (7).

a. visok, (i) debeo

high-short(NOM.SG.M) and thick-short(NOM.SG.M) wall

'a high, (and) thick wall'

b. debeo, (i) visok zid

'a thick, (and) high wall'

(Aljović, 2010:42)

\subsubsection{German}

Unlike adjectives in BCS in which the inflection on the adjective determines the interpretation of the noun phrase, in German, the agreement morphology on the adjectives differentiates between the so-called weak and strong inflections. ${ }^{16}$ Adjectives in the context of either a definite or a demonstrative determiners inflect according to the weak paradigm (8a) while a bare adjective is marked with a strong ending (8b).

a. d-er

gut-e

wein

the-MASC. NOM-STRONG

good-MASC. NOM-WEAK wine

'the good wine'

b.

gut-er wein

'good wine'

(Murphy 2018:4)

\footnotetext{
${ }^{16}$ A detailed analysis of weak and strong inflection of adjectives in German can be found in the following works among others: (Corbett 2006; Murphy 2018; Müller 2002a; Roehrs \& Julien 2014).
} 
According to Aljović (2010), German adjectives do not have phi-features, rather adjectives in attributive positions bear agreement morphology. German has a complex system of inflectional morphology (Lobeck 1995). Adjectives take different forms in German depending on the agreement morphology that it occurs with, for example, adjectives with strong endings have the inflections as shown in table 3.1. while adjectives with weak endings have the inflections in table 3.2.

German tables of strong and weak inflections according to Roehrs (2006:168).

Table 3.1: Strong adjectival inflections in German

\begin{tabular}{|l|l|l|l|l|}
\hline case $\backslash$ gender & masculine & neuter & feminine & plural \\
\hline nominative & gut-e-r & gut-e-s & gut-e & gut-e \\
\hline accusative & gut-e-n & gut-e-s & gut-e & gut-e \\
\hline dative & gut-e-m & gut-e-m & gut-e-r & gut-e-n \\
\hline genitive & gut-e-n & gut-e-n & gut-e-r & gut-e-r \\
\hline
\end{tabular}

Table 3.2: Weak adjectival inflections in German

\begin{tabular}{|l|l|l|l|l|}
\hline caselgender & masculine & neuter & feminine & plural \\
\hline nominative & gut-e & gut-e & gut-e & gut-e-n \\
\hline accusative & gut-e-n & gut-e & gut-e & gut-e-n \\
\hline dative & gut-e-n & gut-e-n & gut-e-n & gut-e-n \\
\hline genitive & gut-e-n & gut-e-n & gut-e-n & gut-e-n \\
\hline
\end{tabular}

Using the analysis of the structure of LFs and SFs in Slavic languages, Aljovic (2010) shows that predicative adjectives are structurally different from attributive adjectives in German. 
(9) a. Der Hund ist klein

The dog is small

'The dog is small.'

b. der klein-e Hund (ein klein-er Hund)

the small-AGR dog a small-AGR dog

'the small dog'

(Aljović 2010:48)

The suffixes, $-e$ and -er are suffixed to adjectives in attributive positions. In predicative positions, adjectives in German do not show agreement morphology.

\subsubsection{Interim Summary}

In the selected languages, we observed the following about the lexical category 'adjective':

(i) attributive forms are more complex than the predicative forms.

(ii) attributive forms are structurally different from the predicative forms.

(iii) in some cases, predicative and attributive forms are in complementary distributions (German).
Russian - SFs are restricted to a predicate construction
- both LFs and SFs are grammatical in predicative expressions
BCS - both forms are grammatical in attributive positions
- LFs are restricted to attributive positions
German - inflected adjectives (weak/strong) are restricted to attributive positions
- $\quad$ uninflected adjectives are found only in predicative positions ${ }^{17}$

\footnotetext{
17 The summary given here is not exhaustive. There are some inconsistencies in the syntactic positions of LFS and SFS in the languages discussed. For the purpose of this work, it is enough to point out these characteristics since they are directly related to the aim intended for this work.
} 
An interesting similarity in the languages discussed above, is twofold: (i) the occurrence of a suffix in one of the two forms of adjectives. (ii) apart from German, there is an asymmetry between the adjectives. In both Russian and Serbo-Croatian, either the LF or the SF is restricted to appear in only one position (predicative and attributive), whereas the other is free to appear in either position. It is also interesting to note that both forms of adjectives in the three languages are grammatical in a canonical adjective position either a predicative position or an attributive position. In the remainder of this chapter, I show that attributive forms in Ògè are restricted to an attributive position. Most importantly, the roots of NAMs that are discussed in this chapter occur in predicative constructions, this is necessary because of two important reasons: (i), Ògè does not have adjective as a lexical category, hence the attributive forms must be derived from an existing lexical category (verbs, predicative forms) (ii) predicative forms are analyzed as stative verbs (see section ((3.5.), for more details on this) and as a result of this, they are like unaccusative verbs in English which only allow one argument which starts out as its object and ends up as its subject. This means that predicative forms in Ògè do not take two arguments, hence, the restriction to a predicative position (iii), NAMs are nominal and only nominals are modifiers in Ògè. This chapter proceeds as follows: section 3.3. discusses the structure of attributive modifiers in Ògè. Section 3.4. discusses attributive modifiers in Yorùbá a closely related language to Ògè, the aim of this section is to further support the general claim in this chapter that adjectives as a lexical category is not a universal category. Evidence is provided in section 3.5. to show that the form from which attributive modifiers are derived is itself not an adjective but a stative verb in both languages (Ògè and Yorùbá). 


\subsection{Nominal Attributive Modifiers (NAMs) in Ògè}

This section discusses attributive modifiers in Ògè. Attributive modifiers in Ògè are restricted to an attributive position as shown in (1a) repeated here in (10a). This shows that they are never found in a predicative position (10c) while the example in (10b) is grammatical in which go 'old' is used instead of the attributive form igogo 'old or oldness'.

(10) a. ígé í-go-go ópú
DEM NMLZ-old-old dog
'that old dog'

b. Ígé ópú go.

DEM dog be. old

'That dog is old.'

c. *ígé ópú ígogo

Int: the dog is old

As clearly shown in the example in (10a), the attributive form is prefixed with $i$ followed by the reduplication of the root form. This chapter shows that predicative and attributive modifiers have different forms as seen in the languages in section 3.2. but what appears to be adjectives in attributive position are nominal elements in Ògè. Dixon (1982) and Dechaine (1993) argue that in most of the Niger-Congo languages, the lexical category 'Adjective' represents a closed class of words. Ògè lacks free forms for predicative forms, the form from which the attributives are derived is itself not an adjective but a stative verb. This chapter proposes that unlike Russian, BCS, German and many other European languages where the predicative adjective occurs with an inflectional suffix in attributive 
constructions, Ògè resorts to the nominalization of roots for this purpose. I support this proposal with a morphological and syntactic analysis of NAMs and show that attributive modifiers are free nominals. Further, I show that apart from the $i$ prefix that is found with the attributive modifiers, an $\grave{a}$-prefix also occurs with the predicative forms and derives a similar lexical item with the interpretation that is like the interpretation of the attributive modifiers, à-go 'oldness'. However, the derived forms with the $\grave{a}$-prefix are only grammatical in a derived position (see section 3.3.2.).

\subsection{1. í-NAMs in Ògè}

As the examples in (1 and 10) show, NAMs in Ògè are prefixed with $i$ in attributive positions. $i$ - NAMs are further sub-divided into two sub-groups; $i$-NAMs-I and $i$ - NAMs-II. The forms of $i$-NAMs-I that are not reduplicated can appear in the predicative positions (11a) while the full form of $i$-NAMs-II occurs in predicative position (12a).

(11) a. Ígé ópú go. DEM dog be. old 'That dog is old.'

b. ígé í-go-go ópú

DEM NMLZ-old-old dog 'that old dog'

(12) a. Ígé ópú kè-gbègbè.

DEM dog ASP-small

'That dog is small.' 
b. ígé í-gbègbè ópú

DEM NMLZ-small dog

'that small dog'

c. * Ígé ópú gbè

DEM dog ??

The example in (11a) shows that go translates to 'be. old', when it occurs in attributive position (11b), go fully reduplicates and it is prefixed with $i$. In (12a), the full copy of gbè is only grammatical in predicative position when it is suffixed to kè. I further show in (12c) that the un-reduplicated form of gbègbè which is gbè is not grammatical in the predicative position. Both NAMs: $i$-NAMs-I and $i$-NAMs-II belong to the same group ' $i$ NAMs' because they both occur in the attributive position with the $i$-prefix. The item which occurs with the full form of NAMs in predicative position $k e ̀$ is an aspectual marker as the examples in (13) show.

(13) a. Sadé kè jọ̀ únọ Sade Perf do work 'Sade has worked.'

b. Dúpẹ́ kè pù ópú Dupe Perf kill dog 'Dupe has killed the dog.'

The examples in (13) show that kè is merged with the transitive verbs jò 'do' and pù 'kill'. Following Adger (2003), I propose the syntactic tree in (14a) for the sentence in (13a). 
(14) a.

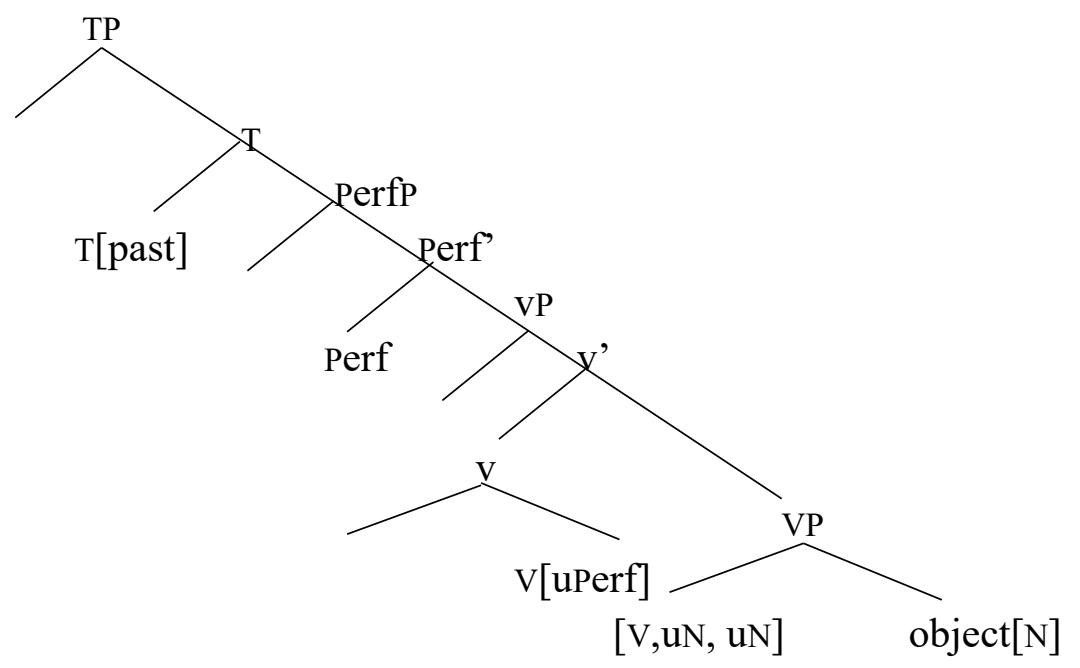

The derivation in (14a), shows that the perfective auxiliary is merged outside of the vP. I assume that the perfective auxiliary kè in Ògè has the interpretable feature [Perf]. When a category bears an interpretable feature, the category is interpreted as carriers of the semantics of the feature, in this case, kè is interpreted as the carrier of the semantics of perfective. I assume that the little $v$ in the derivation in (14a) bears an uninterpretable noun feature. Uninterpretable features are features that are only formal features and not semantic in nature and they cannot receive an LF-interpretation (Zeijlstra, 2014). I propose that unlike English where the perfective phrase bears an uninterpretable inflectional feature, the perfective phrase does not bear this feature in Ògè. The structure in (14b) is the full representation including the lexical categories.

b.

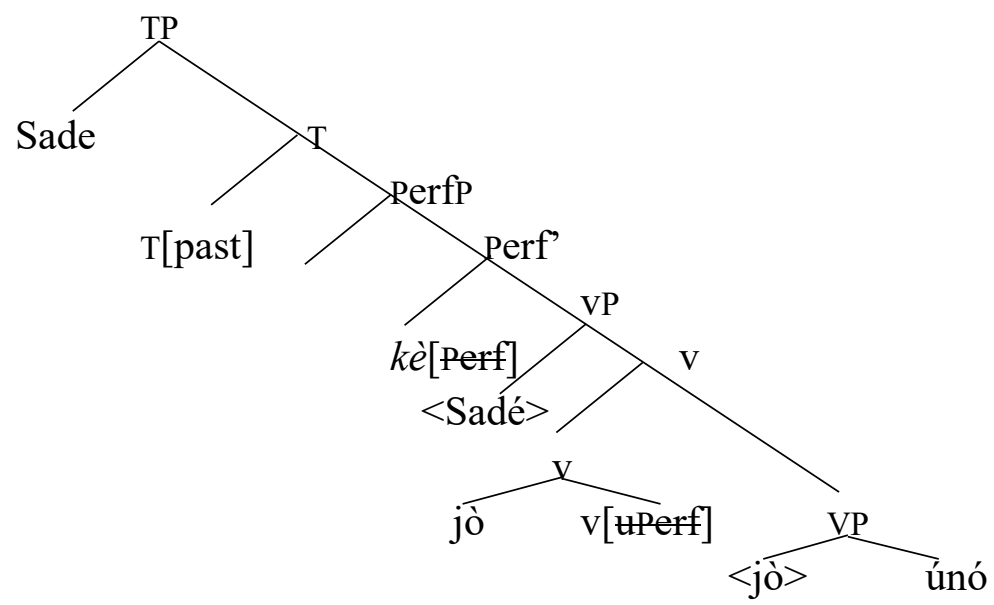


As shown in (14b), the verb jò 'do' bears an uninterpretable noun feature, it is merged with únó 'work' to satisfy the uninterpretable feature [uN]. After satisfying this feature, the c-selectional feature of the little $v$ projects along with its other features $[\mathrm{v}, \mathrm{uN}]$ to the $v$ bar mother node where the subject is merged at the specifier of the little $v$ to satisfy this feature. The perfective phrase is merged headed by the perfective marker kè along with its feature [Perf]. At this point in the derivation, as mentioned earlier, the perfective phrase does not bear an uninterpretable inflectional feature because in past tense constructions, kè does not undergo a morphological process i.e., have had. In a language like English, the perfective phrase needs to bear an uninterpretable inflectional feature that must be valued by the null head T. As shown in (14b), TP is merged while the head of the TP bears a past tense feature to show that the sentence is in its past form. I claim that in Ògè, the head of the perfective phrase is only occupied with kè when the merged verb is a transitive verb (13). I present the steps involved in the derivation of an intransitive verb with kè in $(14 c)$ :

c. Step I: gbègbè is merged as the daughter of the VP while ígé ópú 'that dog' is merged as its object

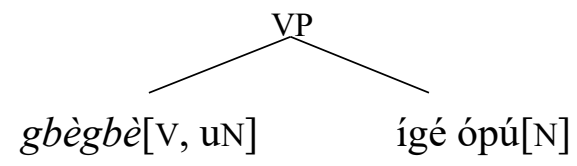

Step II:gbègbè is suffixed to kè which allows its object to check its [uN] feature ${ }^{18}$

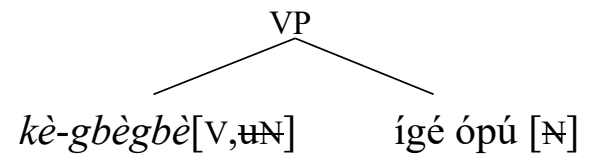

\footnotetext{
${ }^{18}$ This step is important because without kè, the full form of the root is not grammatical in this position. So, it is the presence of kè that allows the occurrence of gbègbè in this position.
} 
Step III: kè-gbègbè moves to the little v to check the strong [uPerf*] feature on little v which forces it (kè-gbègbè) to remain in little v.

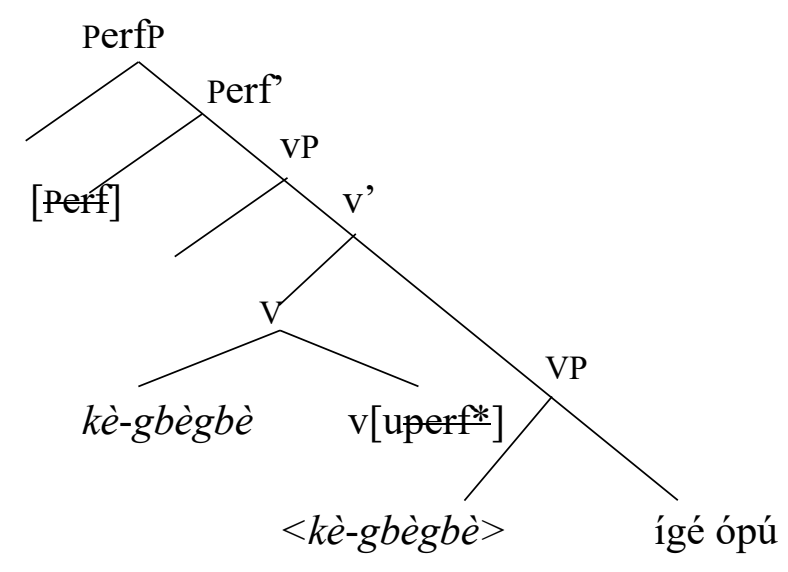

Step IV: $\quad$ the EPP on the Thead forces the object of the VP to move to the specifier of the TP.

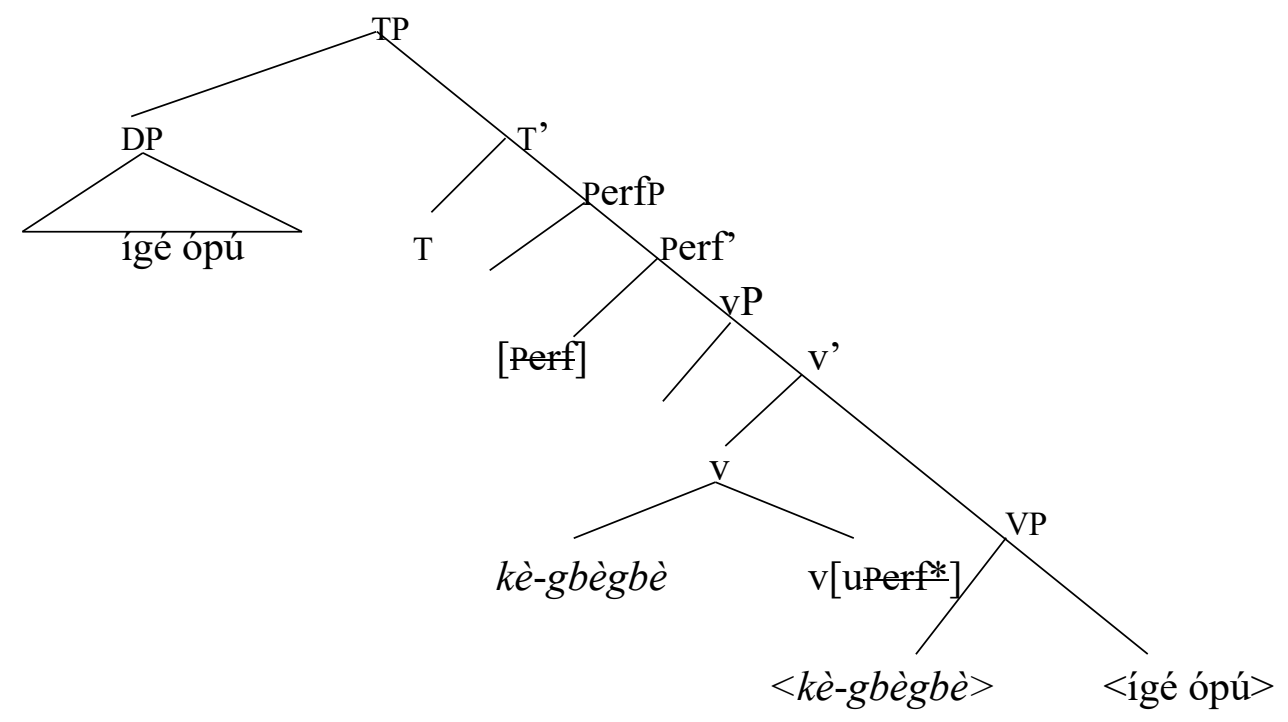

It is important to note that in the derivation of the predicate forms as laid out above, the little $v$ lacks a subject in its specifier just like un-accusative verbs in English. In section 3.5., I show that the predicative form of $i$-NAMs-II are like stative verbs in Ògè which further supports the proposal that verbs in Ògè have the same syntactic structure with the forms from which NAMs are derived. 


\subsubsection{Nominalizations in Ògè}

For the purpose of this chapter, I discuss verbs and agentive nominalizations in Ògè. I start by starting that Ògè makes use of the prefixes $i$ and $a ̀$ to derive nouns from verbs. However, derivations with $\grave{a}$ are only grammatical in a derived sentence as shown in (15b) while this is not the case for derivations with $i$.

(15) a. Táyò dà bàtà Tayo buy shoe 'Tayo bought a shoe'

b. À-dá úwọ̀n Táyò dà bàtà NMLZ -buy FOC Tayo buy shoe 'It was buying that Tayo did to the shoe'19

(16) a. Àran í-pù áà sọn goat NMLZ-kill NEG good 'The act of killing a goat is bad'

b. Èsue í-jù sọn fish NMLZ-eat good 'The act of eating a fish is good'

Unlike the $\grave{a}$-prefix that is restricted to the derivation of a noun from the verb in a derived position as shown in (15b), the prefix $i$ is found in three different constructions, agentive as shown in (17), gerunds as shown in (16) and repeated here in (18) and NAMs as shown in (19).

\footnotetext{
${ }^{19}$ See section (3.3.2.1.) for more on this.
} 


\section{Agentive}

(17) a. ẹnẹ-í-pù-ẹnẹ

Person-NMLZ-kill-person

'murderer'

b. ẹnẹ-í-chẹ-éshín person-NMLZ-sweep-floor 'sweeper'

\section{Gerund}

(18)
a. Àran í-pù áà sọn
goat NMLZ-kill NEG good

'The act of killing a goat is bad.'

$\begin{array}{ll}\text { b. Èsue í-jù } & \text { sọn } \\ \text { fish NMLZ-eat } & \text { good }\end{array}$

'The act of eating a fish is good'

\section{NAMS}

$\begin{array}{llll}\text { Pred. form } & \text { Gloss } & \text { NAMs } & \text { Gloss } \\ \text { hò } & \text { 'be.white' } & \text { í-hò-hò } & \text { 'white or whiteness' } \\ \text { gọ } & \text { 'be.old' } & \text { í-gọ-gọ } & \text { 'old or oldness' }\end{array}$

The examples in (17) show that $i$ is prefixed to eventives with the forms CV while the examples in (19) show that it prefixes to statives (see section 3.5. for further justification for this). This means that the $i$-prefix in Ògè is used in two contexts (i) it prefixes to a CV syllable to derive a gerund from the verb form (ii) it prefixes to a reduplicated segment $(\mathrm{CV}-\mathrm{CV})$ to derive a NAM. Further justification for the second type is the example in (12), repeated here in (20).

(20) a. Ígé ópú kè-gbègbè.

DEM dog ASP-small

'That dog is small.'

b. ígé í-gbègbè ópú

DEM NMLZ-small dog

'that small dog' 


$$
\begin{gathered}
\text { c. *ígé gbègbè ópú } \\
\text { DEM small dog }
\end{gathered}
$$

The example (reduplicated item) in (20a) is prefixed with the perfective marker kè (see example 14) in predicative construction while the reduplicated form in (20b) is prefixed with the $i$-prefix to derive the attributive form, the ungrammaticality of the example in (20c) shows that the $i$-prefix is necessary for the correct interpretation of the attributive form.

\subsubsection{Internal structure of $i$-NAMs}

According to (Embick \& Marantz, 2008), roots are categorized by combining with category-defining functional heads. According to them, these category-defining heads are called categorizers and a root can either be nominalized, verbalized or adjectivized merging with specific nominalizers with ' $n$ heads', verbalizers with ' $v$ heads' or adjectivizers with ' $a$ heads' respectively. In Ògè, the categorizers are phonologically overt in the derivation in (21).

Following Marantz (2001), I adopt the representation in (21) for the internal structure of $i$ - NAMs.

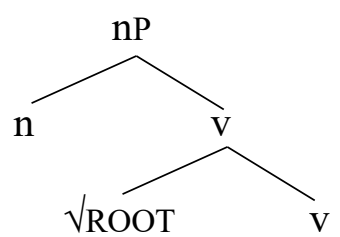

In (21), the root combines with a category defining node, $v$ while the nominalizer i.e., $n$ makes changes to the shape and syntactic relationships of the derived word. It is important to note that the root and the derived form both have the same interpretations while the 
derived form has an additional interpretation which is nominal (this interpretation is absent for the root form).

\section{Ògè Gloss}

(22) a. hò - be.white

Éswé hò. A/The House is white.'

b. 1́-hò-hò - white or whiteness í-hò-hò éswé 'white house'

In $(22 a-b)$, the semantics of the root remains the same, while nominalization affects the form and the syntactic distribution of the derived form. In addition, the motivation for the structure in (21) comes from the fact that the basic semantic information of the roots remains the same while the $n$ head is a functional layer which affects the distribution of the derived form in this case: from a predicative form to an attributive form. I assume following Fábregas (2008:2) that $n$ is merged independently of the verbal structure.

$$
\begin{aligned}
& \text { N-feature embedding } \\
& \text { Take a verbal functional structure and subordinate } \\
& \text { it to a nominal verbal structure. (Fábregas 2008:2) }
\end{aligned}
$$

Following Fábregas (2008:2) and Alexiadou (2010:504-505) who both argued that the affixes in Spanish behave differently depending on the verbal root they nominalize; I propose that the two nominalizers identified in Ògè $i$ and $\grave{a}$ behave differently. For $i$, it can prefix with a CV syllable and with a CV-CV syllable while $a$ does not prefix with a CVCV syllable.

I further claim that the form of the modifier with the prefix $i$ indicates that $i$ has a RED(uplication) morpheme as part of its lexical specification.

(23) $\mathrm{n}<->\mathrm{i}+\mathrm{RED} /\{\mathrm{i}-\mathrm{NAM}$ roots $\}$ 
The reduplicated form hò-hò is not grammatical in isolation like gbègbè in (20c). The example in (24) shows that in predicative position, the basic meaning attributed to the predicative form can only be interpreted as 'white', while the meaning associated with the nominalized form $(25 \mathrm{a}, \mathrm{b})$ is ambiguous between the two readings; white or whiteness.

ígé éswe hò

DEM house be.white

'The house is white.'
a. ígé í-hò-hò
éswe
DEM NMLZ-white-white house
'the white house'
b. í-hò-hò ígé éswe
NMLZ-white-white DEM house
'the whiteness of the house'

The sentence in (24) can only be interpreted as 'the house is white' in which hò has the literal meaning of 'be.white'. The next section discusses the à-prefix in Ògè. The essence of the section is to show that in derived sentences, (focus and relative clauses) the verb is prefixed with $\grave{a}$ and the interpretation of the verb in the derived position is like the attributive form because the derived forms with the $\grave{a}$-prefix are restricted to a derived position as shown earlier in (15).

\subsection{2. $\quad \grave{a}$-prefix}

This section discusses the structure of a derived noun with the $\grave{a}$-prefix in relation to focus constructions and relativization. I show that $\grave{a}$ is a nominalizer in Ògè by providing evidence from focus and relativisation constructions. To start with, I present the earlier version of the strategies of focus constructions as presented in Adénúgà (2014) in 3.3.2.1. 
In 3.3.2.2., I give a revised version of the analysis presented in 3.3.2.1. and I give some examples of relative clauses in Ògè. The example of relative clauses is necessary to show the parallelism between the occurrence of $\grave{a}$ on a focused verb and on a relativized verb.

\subsubsection{Focus constructions in Ògè}

According to Adénúgà (2014), two strategies are used in verb focus in Ògè; movement of the verb from its canonical position to a position outside the clause that contains it. ${ }^{20}$ At the sentence initial position, the verb is nominalized with a $\grave{a}$-prefix (26b). A copy of the verb is retained at the extraction site and the nominalized verb is followed by the focus marker úwọnn (Adénúgà, 2014).
a. Táyò dà bàtà
b. À-dá
úwọ̀n Táyò dà bàtà
Tayo buy shoe
NMLZ-buy FOC Tayo buy shoe
'Tayo bought a shoe'
'It was buying that Tayo did to the shoe'
c. $\quad$ e úwọ̀n Táyọ̀ dà bàtà
(Adénúgà 2014:72)

The schema in (26c) shows that when a verb is focused in Ògè, it is moved to the sentence initial position where it is prefixed with $\grave{a}$ in order to make it into a noun. Adénúgà argues for a focus phrase (FP) structure for Ògè focus constructions as shown below;

\footnotetext{
20 The strategy of verb focus that is being discussed here is quite common in African languages in which the verb is moved to the left periphery and a copy is left in-situ (Awóbùlúyì (1992) for Yorùbá, Biloa (1995) for Tuki and Hyman and Watters (1984)).
} 
d.

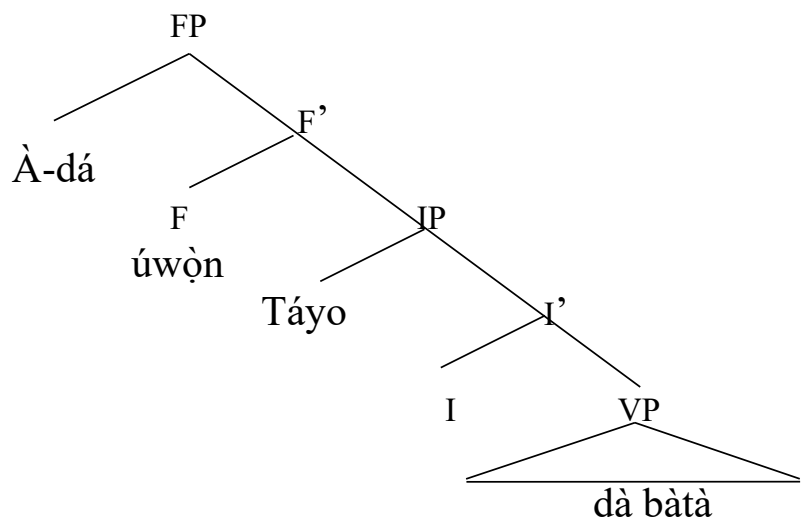

(Adénúgà 2014:72)

The main proposal in Adénúgà (2014) on the nature of focus constructions in Ògè is that in verb focus, a vowel is prefixed to the verb at the A-bar position: at the landing site of the moved verb. The second proposal is that there is an item $u$ wọn whose function is to mark focus on the moved constituent as shown in the examples in (27). The subject (27a) and the object (27b) constituents are followed by úwọn at the left pheriphery of the clause while the ungrammaticality of $(27 \mathrm{c})$ and $(27 \mathrm{~d})$ show that in addition to $u$ wọ̀n, à must be prefixed to a focused verb at the landing site.

\section{Subject focus}

(27)

a. Táyò úwọ̀n dà bàtà.

Tayo be buy shoe

'It was Tayo who bought the shoe'

c. *dà úwọ̀n Táyọ̀ dà bàtà

eat be Tayo buy shoe

\section{Object focus}

b. Bàtà úwọ̀n Táyò dà. shoe be Tayo buy 'It was shoe that Tayo bought'

d. *dà nì Táyọ̀ dà bàtà eat REL Tayo buy shoe

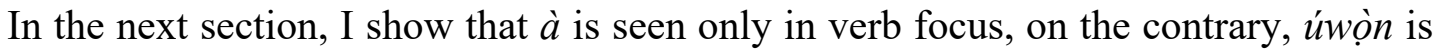
always present in all instances of focus in Ògè and not only in verb focus. I also argue against a focus phrase analysis for focus constructions in Ògè. 


\subsubsection{Alternative analysis of focus constructions in Ògè}

Recall from the previous section that the head of the focus phrase as proposed in Adénúgà (2014) is úwọn. A closer look at the item úwọn suggests that it is a non-canonical head if we assume that heads are typically of the form (C)V. The form úwọn is presumably V-CV. I went a step further to establish the status of úwọn in Ògè and I observed that the use of $u$ ùọn is not restricted to a focus environment. Úwọn is found in constructions as shown in (28).

$\begin{array}{lllll}\text { a. idi úwọ̀n } & \text { sú } & \text { b. àvá úwọ̀n sú } & \text { c. éwò úwọ̀n sú } \\ 2 \mathrm{SG} \text { be } & \text { own } & \text { 3PL be } \text { own } & 1 \mathrm{SG} \text { be own } \\ \text { 'It is yours' } & & \text { 'It is theirs' } & \text { 'It is ours' }\end{array}$

As shown in (28), úwọ̀n is the equivalent of 'be' in English. Considering this I argue following Adesola (2005) that:

(29) (i) úwọ̀n in Ògè is a defective verb. The claim that úwọn is a defective verb is in line with Yusuf's (1990) analysis of $n i$ in Yorùbá.

(ii) úwọ̀n does not have tense or aspectual interpretation and it states a truth that always holds.

(iii) the nominalized verb in the Spec of $u$ wọ̀n is not derived by movement rather it is base generated.

(iv) just like in Yorùbá, only the null operator moves in the focus construction in Ògè

(v) an example with focus constructions in Ògè is not a single clause but two clauses (30).

$$
\text { [XP ú-wọ̀n }[\ldots] \quad]
$$

I propose the structure in (31) which is a modified version of the structure for focus phrase in Adenuga (2014:72), repeated in this chapter in (26d). 


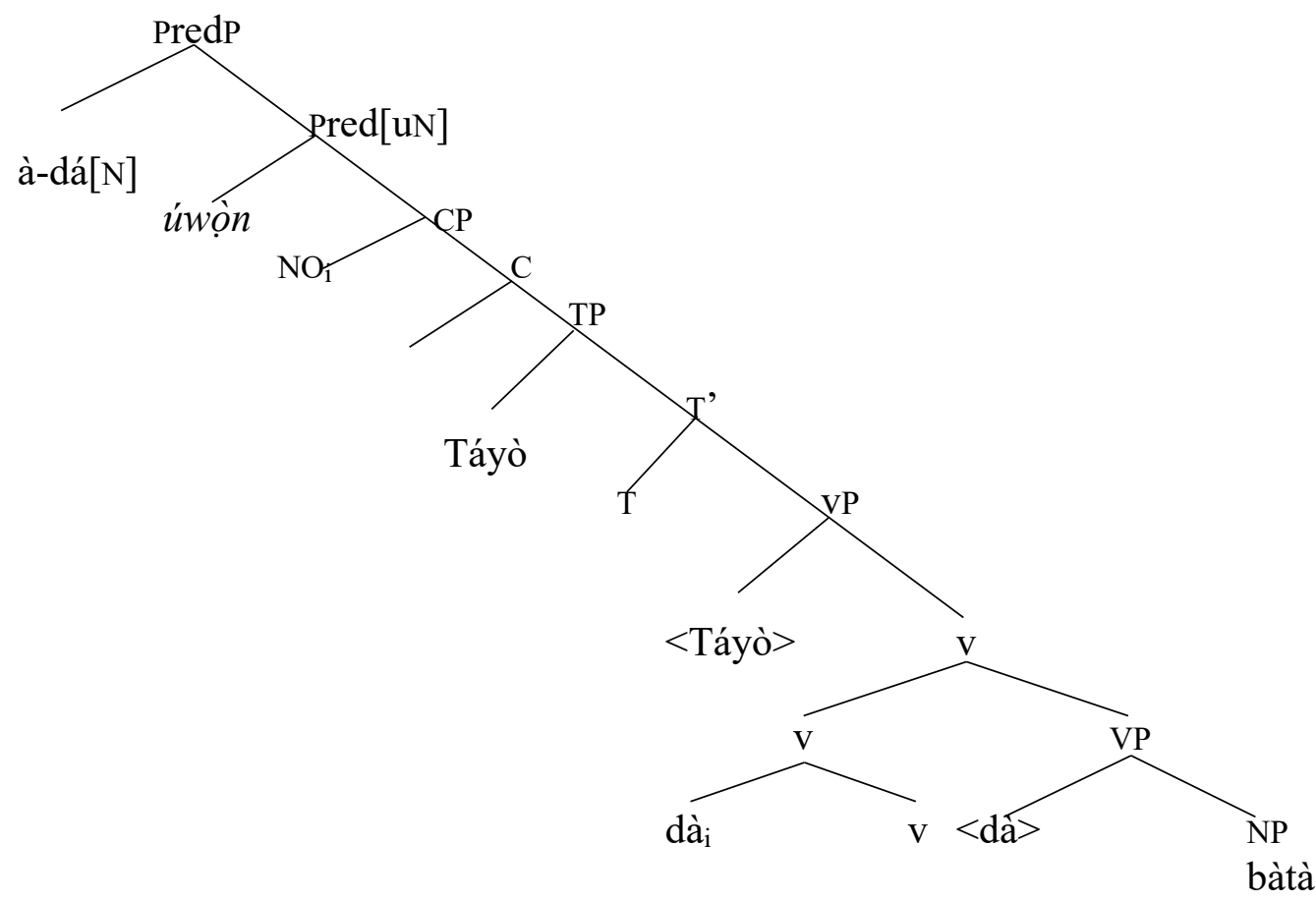

I argue that in verb focus, the focused verb is externally merged at the specifier position of the predicative head. I assume following the feature specifications in Adger (2003) that the predicative head in the structure in (31), bears an uninterpretable noun feature indicated with [uN]. This means that the specifier of $u$ wò̀n must be filled with a noun. The merged focused verb at the specifier position of the Pred. head bears an interpretable noun feature which checks the uninterpretable noun feature on Pred. I also propose that the head of $\mathrm{C}$ is null since the specifier of the NP hosts the null operator. The null operator moves to the specifier position of the $\mathrm{CP}$ of the embedded clause. The null operator is then obligatorily co-indexed with the (base generated) subject of úwọn. Invariably, in focus phrase in Ògè, only the null operator moves. The subject of úwọn is in an argument position and not an A-bar position as analyzed in Adénúgà (2014). We can conclude that the focus construction is bi-clausal and that $u$ wọn is the verbal element in the matrix clause. The verb dà 'buy' cannot appear in an argument position without the vowel $\grave{a}$ as in $\grave{a}-d \grave{a}$. 
In relative clauses on the other hand, relativized verbs are prefixed with $\grave{a}$ followed by the relative pronoun $n i$.

(32) À-dá nì Táyò dá bàtà...
NMLZ-buy REL Tayo buy shoe...
'The buying that Tayo did to the shoe...'

Following Adésolá (2005:53), I also argue that the null operator moves when the verb is relativized and that a relative clause construction is bi-clausal; the $\mathrm{CP}$ is subordinated to the merged relativized verb. The merged relativized verb selects a $\mathrm{CP}$ as its complement which is headed by the relative pronoun.

The form of the verb in the two constructions discussed above (focus and relative constructions) shows that verbs in Ògè are only grammatical in an argument position when they are prefixed with $\grave{a}$. I give further support to this claim with the example in (27) repeated here in (33) in which the subject and object are focused and $\grave{a}$ is not prefixed to the focused constituents.

\section{Subject focus}

(33)

a. Táyò úwọ̀n dà Tayo be buy shoe

'It was Tayo who bought the shoe'
c. *dà úwọ̀n Táyọ̀ dà bàtà
eat be Tayo buy shoe

\section{Object focus}

b. Bàtà úwọ̀n Táyò dà. shoe be Tayo buy 'It was shoe that Tayo bought'

$$
\begin{array}{rrrr}
\text { d. *dà } & \text { nì } & \text { Táyọ̀ dà } & \text { bàtà } \\
\text { eat } & \text { REL } & \text { Tayo buy } & \text { shoe }
\end{array}
$$

In (33), where the subject and the object are focused, no further morpho-syntactic measure is needed on both the subject and the object before they could occupy the specifier of Pred. The only reason being that they are nominal; in Ògè, verbs are 
nominalized with $\grave{a}$ for them to be grammatical when they are either focused or relativized. We see this because of the ungrammaticality of the sentences in (33c-d).

In this section, I showed two important things about the $\grave{a}$-prefix (i) the output of the $\grave{a}$-prefix to the verbs is nominal (ii) the $\grave{a}$ that is found in a focus or a relativized position with the verbs is a nominalizer. The next section presents data from Yorùbá, a closely related language to Ògè and shows that attributive modifiers are also derived from the predicative form in the language. In addition, attributive modifiers in Yorùbá form a closed class of words and they are nominal just like in Ògè.

\subsection{Nominal Attributive Modifiers in Yorùbá}

There is a long-standing debate on the status of what seems to be adjectives in Yorùbá. Most of the authors that have looked into the structure of the predicative and the attributive forms have argued that attributive modifiers are derived from a verb (Awobùlúyì 1978; Bámgbósé 1990 and Ìlọ̀rí 2016) and that the form are lexical verbs. ${ }^{21}$ This chapter gives a detailed syntactic analysis of the structure of attributive modifiers in Yorùbá and proposes that just like in Ògè, attributive modifiers are nominal in Yorùbá, in other words, attributives in Yorùbá are called Nominal Attributive Modifiers (NAMs). For this work, NAMs in Yorùbá are grouped into two; the first group, which I call GRP I NAMS consist of NAMs with the prefix $i$ as shown in (34a), the second group of NAMs are fully reduplicated and they occur without the prefix $i$ as shown in (34b), NAMs in this group are named GRP II NAMs.

\footnotetext{
${ }^{21}$ Ilori argues for the reduplication (both partial and full) of the predicative form in order to derive the attributive forms. For details, see Ìlọrí (2016) for a different analysis of the process involved in the derivation of the attributive forms in Yorùbá. In this chapter, I follow Eléshin's (2017) analysis of the derivations of gerunds in Yorùbá and show that 'i’ is a unique vowel which derives gerunds in Yorùbá. Following this line of arguments, I argue that attributive forms are derived through the nominaliser $i$ (see section 3.4.1.1.) for the detailed analysis.
} 

a. Ajá g-í-ga
b. ajá funfun
dog C-NMLZ-be.tall
dog white
'tall dog'
'white dog'

This section is organized as follows; section 3.4.1. presents the analysis of the structure of NAMs in GRP I while section 3.4.2. establishes the generalization of my proposal on the high tone that is found in GRP I NAMs. In 3.4.3., I discuss GRP II NAMs and establish that even though the GRP II NAMs do not have the prefix $i$ as shown in (34b) above, NAMs in this group share the same syntactic distributions with NAMs in GRP I.

\subsubsection{NAMs in Group (GRP) I}

NAMs in GRP I are prefixed with $i$ after which the consonant of the root is copied to the left of the prefix Eléshin (2017). It is interesting to note that the form of NAMs in GRP I are the same as the form of gerunds in Yorùbá as shown in (35).

$$
\begin{aligned}
& \text { Mo fẹ́ràn an } \boldsymbol{d} \text {-í-dé } \quad \text { e } \quad \text { wọn } \\
& \text { 1SG like MTS C-NMLZ-arrive MTS 3PL } \\
& \text { 'I like their arrival' literal meaning in Yorùbá, didé means arrival. }
\end{aligned}
$$

In (35), didé with the literal meaning of 'arrival' is derived from the form dé 'arrive', the derived form didé has the same structure with giga 'tall' as shown in (34a). This section is organized as follows; section 3.4.1.1. discusses some of the previous analyses of the internal structure of gerunds, since the structure of gerunds are the same as the structure of NAMs in GRP I. Some of the earlier analyses that are discussed are that of: (i) Pullyblank (2008) who argued for a [Ci] prefix to the verb root and (ii) Eléshin (2017) who proposes that the high tone $i$ is a nominalizer in Yorùbá. Section 3.4.1.2. discusses the syntactic 
status of the high tone independent of the vowel that bears it, this is based on the syntactic account of NAMs in GRP I that was proposed in section 3.4.1.1.

\subsubsection{Previous analyses of the internal structure of NAMs in Yorùbá}

The two lexical items (gerunds as shown in (35) and NAMs as shown in (34a)) have the structure of a partially reduplicated form. Previous structural analyses of the lexical items of this nature claim that the predicative form is partially reduplicated (Awoyalé 1989; Olá 1995; Pullyblank 2008; Ìlọ̀rí 2016). From a phonological point of view, Pullyblank argues that gerunds in Yorùbá are derived through the prefixation of [Cí] to the verb, where " $\mathrm{C}$ " is a copy of the first consonant of the verbal base as shown in (36).
a. rí $\rightarrow$ rí-rí
b. jó $\rightarrow$ jí-jó
see Cí-see
burn Cí-burn
'seeing'
'burning'

Following Newman (2000), Eléshin (2017) argues that the high tone vowel $i$ is responsible for the derivation of gerunds in Yorùbá. Eléshin proposes that the process of word formation that derives gerunds in Yorùbá is strictly the prefixation of the high tone vowel $i$ to the verbal form. The initial consonant of the verbal form is then copied to the left of the high tone vowel. According to Eléshin, the copy of the initial consonant of the verbal form is necessary because of the need to augment the ill-formed structure in (37).
a. $1+$ je
*íje
b. í + mu
*ímu
Pre + eat
Pre + drink

The ungrammaticality of the examples in (37) according to Eléshin is because Yorùbá words do not begin with vowels bearing a high tone. In order to save the derivation from 
crashing in Eléshin's terms, the author employs the augmentation theory where the initial consonant of the base is copied to the left of the $i$-prefix as schematized in (38).

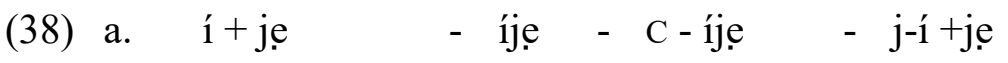

$$
\begin{aligned}
& \text { pre + eat 'eating' } \\
& \text { b. } \quad i ́+m u-i ́ m u-C-i ́ m u-\text { m-í-mu } \\
& \text { pre }+ \text { drink } \quad \text { 'drinking' Eléshin }(2017: 106)
\end{aligned}
$$

Eléshin argues that the high tone prefix $i$ is a unique class that derives only gerunds in Yorùbá. In other words, this approach sees the high tone vowel as a prefix and the head of the derived nominal, and not just as a mere vowel introduced by insertion rule. Most of the scholars who have looked at the phenomenon surrounding the high tone vowel in gerunds agree that the high tone vowel is consistent in this position and that it is a default vowel in gerunds. Put in another way, the high tone vowel cannot be inserted by rule because if it can be inserted by rule then all other vowels should also be grammatical in this context, the other vowels should also be able to be inserted by rule, but empirical data show that this is not the case. It is only the high tone vowel $i$ that is found in all gerunds and NAMs in GRP I, its presence is consistent across all the NAMs in GRP I as shown in (39).
Yorùbá Gloss
a. gb-í-gbó - 'old'
b. d-í-dùn - 'sweet'
c. k-1́-kéré - 'small'
d. b-í-burú - 'bad'
e. d-í-dára - 'good'
f. t-í-tóbi - 'big'
g. g-í-gùn - 'long'
h. f-í-fè - 'wide' 
i. k-í-korò - 'bitter'

I support Ẹléshin's argument that the concept of partial reduplication which involves the insertion of the high tone vowel $i$ does not exist in the formation of GRP I NAMs in Yorùbá. However, I depart from Eléshin's analysis of the high tone vowel as a prefix in the formation of GRP I NAMs. ${ }^{22}$ I propose the following steps for the derivation of NAMs in GRP I in Yorùbá;

(40) a. Input: $\mathrm{ga}=$ predicate form

STEP 1: H-ga $=$ nP headed by a null $n$ with default $\mathrm{H}^{23}$

STEP 2: gí-ga $=n P$ fully specified with a copy of the ' $C$ ' and the insertion of the epenthetic vowel to head the syllable.

The proposal in (40a) is represented on the structure in (40b) below.

b.

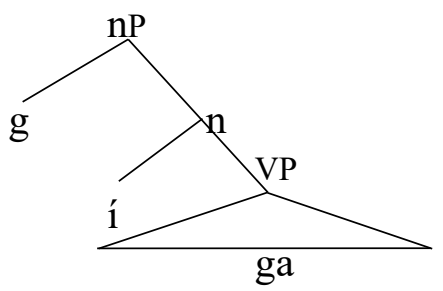

The proposal put forward here for the internal structure of GRP I NAMs is different from the assumptions in Ẹléshin (2017) in two significant ways;

(i) the high tone is a syntactic head as shown in (40b) this analysis is in line with empirical evidence, see section 3.4.1.2;

\footnotetext{
${ }^{22}$ As mentioned in section 3.4.1.1., Eléshin (2017) adopts the augmentation theory for the analysis of the internal structure of gerunds in Yorùbá. Augmentation theory of morphology points out that the realization of the moraic unit used in the augmentation process largely depends on the nature of the base and this is why a segment of the main verb is copied to the initial position of the ill-formed word to save it from crashing, Eléshin (2017:107).

${ }^{23}$ The assumption here is that gerund in Yorùbá is built in syntax by adding some structure to a predicate; which takes a structure of a phrasal node 'DP' whose head D-takes the predicate ' $\mathrm{V}$ or VP' as its complement. This assumption is in line with Fabb's (1984) syntactic affixation.
} 
(ii) the vowel $i$ occurs in the structure in (40b), independent of the high tone. I present evidence in 3.4.1.2. to support the syntactic analysis that I proposed for the internal structure of NAMs in GRP I for Yorùbá.

\subsubsection{Yorùbá high tone is a syntactic category}

In this section, I present the analysis of the high tone independent of the vowel that bears it. Earlier analyses of the high tone in Yorùbá argue that it is syntactic rather than morphological or phonological. Some of the previous analyses that I looked at are those of Manfredi (1992), Ajíbóyè (2005) and Ajíbóyè, Dechaine and Stewart (2003).

According to Manfredi (1992), Syntactic nominalizations in Yorùbá involve the use of the H-tone element. Following Awobùlúyì (1978), Manfredi argues that the reduplication is not always found on the surface. See the sentences in (41).

$$
\begin{aligned}
& \text { (41) a. Ó sòro ó se } \\
& \text { 3SG be.difficult } \mathrm{H} \text { do } \\
& \text { 'It is hard to do.' }
\end{aligned}
$$

(Manfredi 1992:211)

Note that the form of the verb se 'do' changes in (c) to sise which has the same form with NAMs in GRP I as shown in (39). It is also important to note that the sentences in (41a-b) are grammatical sentences in Yorùbá in which the reduplication of sise is not overt. 
Manfredi argues that the reduplicated segmental material exists solely in order to bear the H-tone.

Ajíbóyè (2005) also argues that the H-tone is syntactic in Yorùbá. In (42), the final vowels (the nasal vowel un (42a) and the oral vowel $a(42 \mathrm{~b})$ of the subject DP are lengthened to bear the high tone. The structure in $(42 \mathrm{c})$ is the representation of the sentence in (42a) as presented in Ajíbóyè (2005); The head INFL in (42c), hosts the high tone, while the lengthened nasal vowel $u n$ occurs at the head position of INFL to bear the high tone. As shown in (42d), the sentence is not grammatical without the high tone.
(42) a. Ẹ̀bùn ún jẹ tệtẹ́.
b. Ajá á kú
Ebun HTS eat lottery
dog HTS die
'Ebun won a lottery.'
'The dog is dead.'
c.

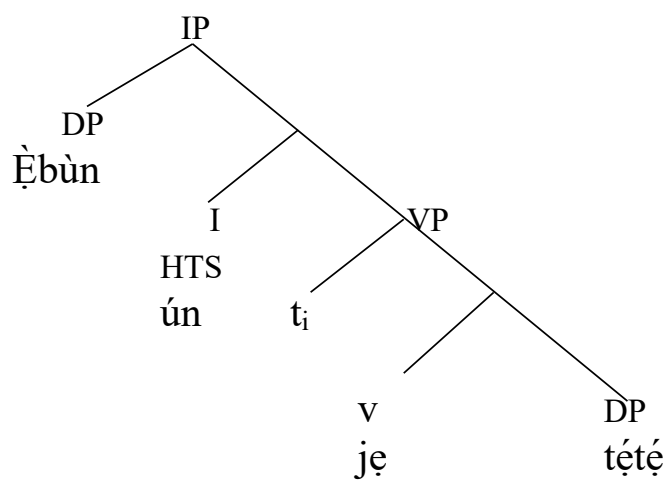
(Ajíbóyè, 2005:104)
d. * Ẹ̀ùn jẹ tẹ́tẹ́
Ebun eat lottery

The examples in (42a-b) show that the high tone is consistent in Yorùbá and that the vowels (un and $a$ ) which bear it, occur for the sole purpose to bear the floating high tone. Many authors have analyzed such segments as a 'high tone syllable' (HTS). The H-tone morpheme in Yorùbá bridges between the nominal (DP) and the sentential (IP) systems of the functional projection. According to Dechaine (1993:457) the HTS is obligatory 
between a full DP subject and a bare verb in Yorùbá. This argument is further supported in Ajíbóyè (2005) who argues that the high tone syllable instantiates a Spec, Head agreement in IP. Take the representation in (43b) for the sentence in (43a) as illustrated in Ajíbóyè (2005:106) as an example;

(43) a. Àgbẹ̀ ẹ́ ní owó

Farmer HTS have money

'Farmers have money.'

b.

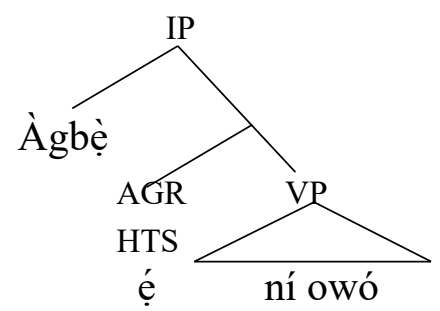

In the same vein, Ajíbóyè, Dechaine and Stewart (2003) posit that the target of gerundive reduplication is the VP and the aspectual auxiliaries which project between the VP and T (for instance, lower auxiliaries).

(44) $[$ тр [

(Ajíbóyè, Dechaine and Stewart 2003:33)

Lower auxiliaries in Yorùbá are lè 'potential', gbọdò 'obligative', máa-ń 'habitualdurative' and $t i$ 'perfective'. The authors argue that the lower auxiliaries are grammatical in the context of the syntactic high tone as shown in (45)

(45) a. Ọkọ̀ ọ́ lè fò. vehicle AGR POT jump

'The craft can/may fly.' 

b. Lí-lè-fò ni ọkọ ọ lè fò.
GER-POT-fly FOC vehicle AGR POT fly
'The craft [focus can/may] fly.'

In (45), the H-tone is seen as an instance of AGR which is licensed in the context of the lower auxiliaries in Yorùbá (Ajíbóyè, 2005). Following Oyèláran (1989) \& Dechaine (1992), the authors argue further that the H-tone which occurs in gerunds is syntactic and not phonological in Yorùbá.

In this section, I provided evidence in support of the proposal that I made in 3.4.1.1. that the H-tone found in GRP I occurs independent of the vowel $i$ that bears it. I looked at the various arguments in support of the syntactic nature of the H-tone in gerunds which is also the same structure as GRP I NAMs. ${ }^{24}$

\subsubsection{Generalization about the high tone in GRP I in Yorùbá}

The proposal on the high tone found between the subject DP and the tense head in Yorùbá are the following;

(i) the H-tone is syntactic, and it is present between the T-head and the vP level in all Yorùbá sentences (42c and 43b).

(ii) when the vP is nominalized, the high-tone cliticizes unto the vP; $i$ is inserted to bear the H-tone in this position (46).
a. j-í-jẹ ẹ̣ tệtẹ́...
C- NMLZ-eat MTS lottery
'the act of winning the lottery...

\footnotetext{
${ }^{24}$ The syntactic analysis of the nature put forward here is not exhaustive because a similar analysis is given in Gungbe for the derivation of verbal reduplication and reduplicated attributive adjectives (Aboh 2007). According to Aboh, if the head INFL is empty, then the verb must reduplicate i.e., in a sequence in which ná (a prospective marker in Gungbe) is absent in the INFL then the verbal element in such a syntactic structure reduplicates. Similarly, to what entails in Yorùbá, there is the interaction between the subject position and the verbal position (Spec Head relation identified in Yorùbá). Aboh further notes that verbal reduplication in Gungbe is syntactically determined.
} 
b.

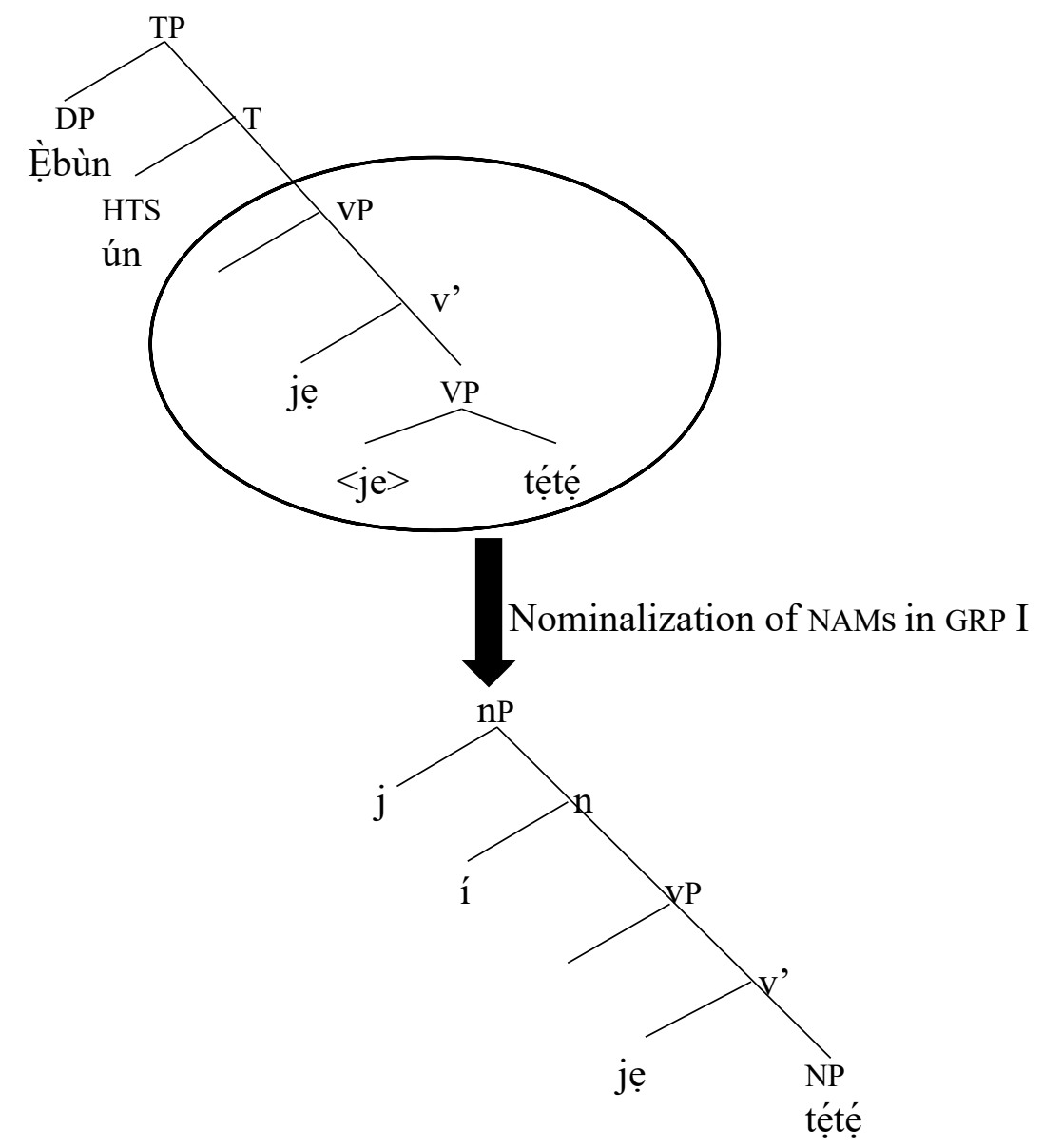

This means that the H-tone in GRP I NAMs is already present at the DP layer in the derivation, when the Pred. form is nominalized, the H-tone at the DP layer cliticizes on the $v$. The vowel $i$ is consistent in the structure of GRP I NAMs. The example in (39) repeated here in (47) are GRP I NAMs.
Yorùbá Gloss
a. gb-í-gbó - 'old'
b. d-1́-dùn - 'sweet'
c. k-í-kéré - 'small'
d. b-í-burú - 'bad'
e. d-í-dára - 'good'
f. t-í-tóbi - 'big'
g. g-í-gùn - 'long'
h. f-í-fè - 'wide' 
i. k-í-korò - 'bitter'

As seen in (48), NAMs in GRP I have their roots in predicative constructions just like $i$ NAMs in Ògè.

(48) a. Ilé yẹn ga.

house DEM be.tall

'That house is tall.'

b. ilé g-í-ga yẹn

house C-NMLZ-tall DEM

'that tall house.'

c. *ajá ga yẹn

house tall DEM

The base form of the GRP I NAMs are not grammatical in attributive position as the example in (48c) indicates. The next section discusses the analysis of the structure of GRP II NAMs.

\subsubsection{NAMS in GRP II}

There are two schools of thought on the internal structure of GRP II NAMs; The first school believes that such words are derived from a base form (Awóbùlúyì 1978:37) while the second school believes that such words have no base form (Bamgbose 1990). For this research, I agree with the first school that the words have a base form from which the full forms are derived. I also assume that for NAMs in GRP II unlike GRP I NAMs, in some contexts, it is possible for the base form to replace the full form in an expression such as the examples in (49a). 
(49)
a. Asọ náà án fún.
b. Asọ náà á funfun. cloth DET HTS white cloth DET HTS white 'The cloth is white.' 'The cloth is white.'

In (49a), fun is used in predicative position while in (49b), the full form is also grammatical in predicative position. My proposal for the internal structure of GRP II NAMs are (i) the high tone vowel is present in NAMs in GRP II, (ii) GRP II are nominal just like GRP I NAMs.

Following İlọ̀rí (2016:131), I propose that NAMS in GRP II are derived from a morphological process which derives a noun from a distinct verb root $\mathrm{V} \rightarrow \mathrm{N}$.
a. $d u ́$
be.black
dídu
$\rightarrow \quad$ dúdú
b. $p \grave{o} \quad \rightarrow$
be.plenty/many
pipọ$$
\rightarrow \quad \text { púpò }
$$$$
\text { plenty/many }
$$

I further propose that the high-tone in the middle column as in didu and pupọ (50) is the same as the high-tone in GRP I and that the words in the middle column are possible alternatives used in place of dúdú and púpọ in some Yorùbá dialects (Ìlộrí 2016:134). The major difference between the two groups of NAMs: GRP I and GRP II NAMs is that the vowel $i$ is overt in the final output of GRP I while it is not in the final output of GRP II. In this section, I have shown that the nominal status of NAMs is not peculiar to Ògè. I achieved this by giving the analysis of NAMs in a closely related language to Ògè which is Yorùbá. 


\subsubsection{Problem for a unified analysis}

It is worthy of note that a unified analysis of the internal structure of NAMs in the two languages discussed (Ògè and Yorùbá) is not plausible. The reason is that the processes involved in the derivation of the attributive forms in the two languages differ, because they concatenate the two morphemes in different orders. The difference is that Ògè high tone plus $i$ occurs outside the root copy, whereas in Yorùbá, the high tone plus $i$ vowel is enclosed by the copy of the consonant as in the example gi-ga. The difference between the two languages is tempting to be described as a mere difference of linearization, but with the same ingredients, only in different orders. A quick observation would be to see if a CV in Ògè can occur in two distinct forms after the concatenation with $i$.

(51) a. FORM 1: 1́- CV as a gerund

b. FORM 2: í- CV-CV as an adnominal modifier

This prediction is born out and this makes Ògè differ from Yorùbá where the output of predicative form concatenation with $i$ are both gerund and NAMs. In Ògè, the category changing item that turns a predicate into an attributive is governed by the nominalizing prefix $i$ and not by reduplication. There is no CV root in Ògè which leads to a minimal contrast between the FORM in 1 and the FORM in 2. This suggests that the prefixation of $i$ is a category changing constituent for lexical structure i.e., $i$ derives gerund, and $i$ derives adnominal modifier. This implicitly means that it is not the case that $i$ adjoins to the same kind of lexical item to derive different lexical item, what it means is that $i$ adjoins to different items to derive the same lexical items (nominal). The function of lexical change is vested on the high tone vowel and not on reduplication. The next section discusses the 
verbal status of predicative forms and establishes that predicative forms are stative verbs in Ògè and Yorùbá.

\subsection{Verbal status of predicative forms in Ògè and Yorùbá}

This section shows that the base forms of NAMs in both languages have the same syntax as verbs. To begin with, I provide evidence from both languages that the predicative forms from which NAMs are derived are grammatical in the same contexts as verbs. First, I show that predicative forms in Ògè are grammatical in the context of the negative marker áà as shown in (52a). According to Adénúgà (2017), áà occurs in a preverbal position to negate the verb (52b). However, it is only the noun that can occur as a complement of $s i$ 'to be' in expressions with the form áà si as shown in (53). The example in (53b) shows that the predicative forms are restricted to a position after áà but not after the string áà si.
a. Ígé áchọ́ áà hò.
b. Sadé áà sìn.
DEM cloth NEG be.white
Sade NEG sleep
'The cloth is not white.'
'Sade did not sleep.'

(53)
a. áà si íhòhòáchọ
b. *áà si hò.
NEG be white cloth
NEG be be.white

'It is not a white cloth.'

In the same vein, the predicative forms in Yorùbá are only grammatical after the negative marker $k \grave{o}$. The derived form is grammatical after the string kil se 'not to be' but not after $k o ̀$ as shown in (55a). The particle se subcategorizes for only PPs and NPs in Yorùbá (Awóbùlúyì 1992) and therefore the predicative forms (verbs) are not grammatical after $s e$ 'to be' but only NAMs (nouns) can be the compliment of $s e$ 'to be'. 
(54) Yorùbá
a. Sadé kò ga.
b. Sadé kò sùn.
Sade NEG be.tall
Sade NEG sleep
'Sade is not tall.'
'Sade did not sleep.'
(55) a. *Sadé kò gíga.
Sade NEG tallness/tall
b. kìi se gíga.
NEG be tallness/tall
'It is not the tall one'

Second, just like un-accusative verbs in English, predicative forms in Yorùbá (56) and in Ògè (57) assign a thematic role to their single argument noun phrase. The claim that unaccusative verbs assign a thematic role to their object in Yorùbá is not a new finding as this has been argued in Awóyalé (1997) and recently supported in Akinlabí and Adésolá (2018:118). I extend this analysis to Ògè.

(56) Yorùbá

a. Isu ú dùn.
yam HTS sweet
'The yam is sweet.'

(57) $\grave{O g} \grave{e}$
a. Ìkári ìsi yẹ̀n.
DET yam sweet
'The yam is sweet.'

In sentences such as (56) and (57a), Adger (2003:184) assumes that the DP ikári isi/isu 'the yam' is internally merged as the daughter of the VP where it is assigned a theme theta role. The representation in (57b-c) is a syntactic tree for the sentence in (57a). 
b.

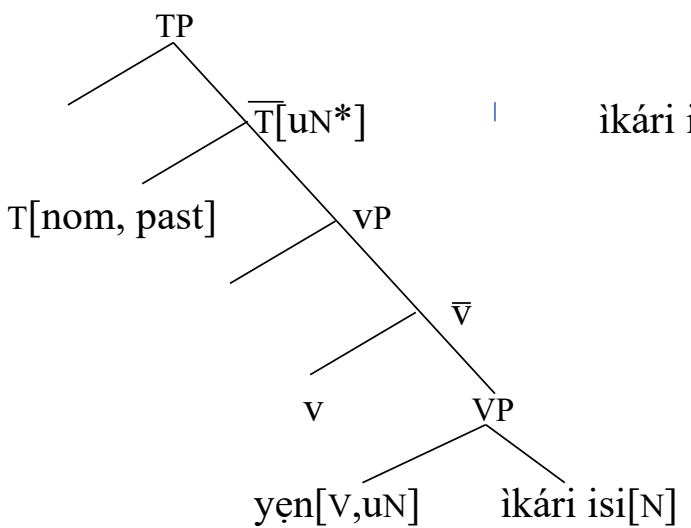

c.

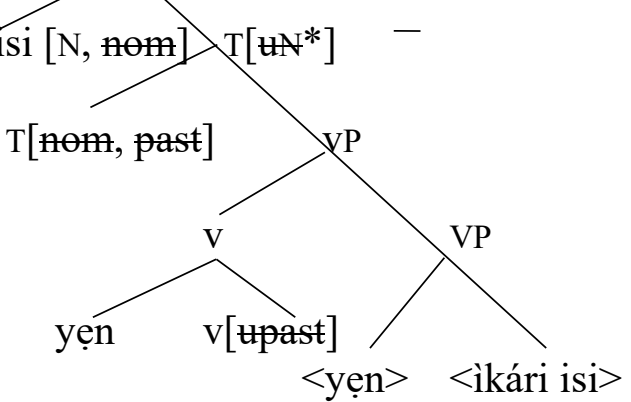

The representation in (57b) shows the features while (57c) shows the movement of the DP to the specifier of the TP. The Thead bears a strong uninterpretable noun, the DP ikári $i s i$ 'the yam' with an interpretable noun [N] feature is merged as the daughter of the predicative form yẹn which bears a verb feature and an uninterpretable noun feature [V, $u N]$. The syntactic structure in $(57 \mathrm{c})$ indicates the checking of the features and the movement of the predicative form to the head of the little $v$ and the movement of the DP ikári isi 'the yam' to the specifier of the TP. I assume that a predicative form lacks a selectional [uN], hence the absence of a subject at the specifier position of the little $\mathrm{v}$. This is like the analysis proposed for $i$-NAMs-II in section 3.3.2.1 as extensively shown in (14c). The representation in (58a) is not attested while (58b) is grammatical.

(58) a. Pred. form $*[\mathrm{~V}, \mathrm{uN}, \mathrm{uN}]$

b. Pred. form $[\mathrm{V}, \mathrm{uN}]$

The representation in (58a), is not grammatical because the predicative form has only one argument which checks its single uninterpretable noun feature as shown in (58b). The object argument of the predicative root can undergo movement to satisfy the EPP feature on $\mathrm{T}$ because there is no intervening subject between the EPP feature of $\mathrm{T}$ and $\mathrm{N}$ feature of theme, here ikári isi 'the yam'. Third, predicative forms are optionally preceded by the 
aspectual markers sè (for Ògè) (59) and $t i$ (for Yorùbá) (60) just like stative verbs. The examples in (59-60), show that predicative forms are optionally preceded by a perfective marker in Ògè and Yorùbá.

(59) Ògè
a. Sadé (sẹ) dà áchọ́.
b. Ígé áchọ́ (sẹ̀) hò.
Sade PERF buy cloth
DEM cloth PERF be. white
'Sade has bought the cloth.'
'The cloth was white.'

(60) Yorùbá
a. Sadé (ti) ra asọ.
b. ilé
(ti) tẹ̀.
Sade PERF buy cloth
house PERF be. bent
'Sade has bought the cloth.'
'The house was bent.'

In both languages, the perfective marker is not obligatory in sentences denoting a perfective action; in essence an expression like Mo rí ajá with the literal translation of 'I see dog' is correctly interpreted as 'I saw a dog' or 'I have seen a dog' the same applies to the sentences in (59a) and (60a). In (59b-60b), tè 'bend' and hò 'white' are the predicative form from which títè and íhòhò (the attributive form) are derived.

Fourth, the predicative forms are grammatical in the context of a future tense morpheme rá (for Ògè) and yóò (for Yorùbá). In (61b-62b), I show that the verbs vè and wá 'come' are grammatical in this context just as the predicative forms go and tóbi 'big'.

(61) Ògè
a. Sade rá vè
b. Ígé úngwọ rá go
Sade FUT come
DEM tree FUT be. old
'Sade will come'
'That tree will be old.' 
(62) Yorùbá
a. Sade yóò wá
b. Igi yóò tóbi
Sade FUT come
tree FUT be. big
'Sade will come.'
'The tree will be big.'

It is important to note that NAMs are not grammatical in all the positions of occurrence of the predicative forms in (61-62). We also see that verbs are acceptable in these contexts which show clearly that predicative forms are stative verbs in the two languages. In this section, I argue that the predicative forms from which NAMs are derived are verbal category in Ògè and Yorùbá. Put in another way, unlike Russian, BCS and German in which the attributive form of adjective is said to be derived from a predicative adjective, in Ògè and by extension in Yorùbá, there is no predicative adjective from which the attributive form could be derived. The source possessed by both languages (Ògè and Yorùbá) for attributive modifier are stative verbs.

\subsection{Implications of the analysis}

This section discusses the implications of the analysis of adjectives in Ògè as a nominal category. The chapter has been on the different structures of adjectives in some European and non-European languages. Importantly, it discusses the strategies of nominal modification with attributive adjectives in Ògè and argue that unlike adjectives in the European languages that are discussed in section 3.2., in Ògè, attributive modifiers are nominal. In effect, this section provides the answer to the question in (63)

(63) why do the two languages (Ògè and Yorùbá) require a copy (in one way or the other) of the root in order to form an attributive modifier.? 
The question in (63) is also related to why predicative verbs are not used in attributive positions in the two languages or why nominalization is resorted to in order to modify a noun. As shown and argued in this chapter, the two languages systematically lack predicative adjectives and therefore, are required to reduplicate their predicative forms. This, in essence, means that the different structures of the predicative forms seen in the attributive positions in Ògè and Yorùbá are related to the independent fact that the languages lack predicative adjectives. What they have are undifferentiated predicative forms that are restricted to the predicative expressions. These sets of predicative forms are called 'verbs' by scholars in Africa because they sometimes translate to verbs as used in the European languages, but other times they translate adjectives or prepositions. So, the syntactic theory of adjectives in Ògè and Yorùbá says that the obligatory change in the structure found in the attributive modifiers of Ògè and Yorùbá as opposed to the European attributive adjectives, is explained by the fact that Ògè and Yorùbá have no predicative adjective from which to derive the attributive adjective. Ògè and Yorùbá languages resort to the nominalization of the predicative forms for this purpose, this is evident because all the so-called attributive adjectives in the two languages are nominals. The difference is that European languages are not forced to nominalize the predicative forms every time they want an attributive adjective, but Ògè and Yorùbá have no choice in the matter. As shown in section 3.5., stative verbs in the two languages have a single argument which starts out as the object but ends up as the subject as shown in (58) repeated here in (64).

(64) a. Pred. root *[V, uN, uN]

b. Pred. root $[\mathrm{V}, \mathrm{uN}]$ 
This is quite different from eventive verbs like dà 'buy' or pù kill which all have two arguments; subject and an object. Before a stative verb could modify a noun, such a verb must be made nominal in order to perform an attributive function. This is different from the system of attributive modification that we see in the European languages in section 3.2. Additional evidence is given in Dutch in (65). For Dutch, the predicative adjective mooi 'beautiful' must occur with the suffix $e$ in attributive position because, the suffix needs to agree with the modified noun. In predicative position, the suffix is not necessary because the predicative form lacks an NP object that needs agreement.

(65) Dutch

a. Het mooi-e huis

The beautiful-DEF.SG.NEUT house

'A / the beautiful house.'

b. Het/een huis is mooi*(-e) $^{*}$

The/a house is beautiful

'The / a house is beautiful.'

(Zeijlstra 2020)

According to Zeijlstra (2020), when the suffix occurs with the adjective in predicative position (65b), then the sentence is not grammatical. In Dutch, the inflectional marker on adjectives of this kind (attributive position) agrees with the determiner Het/een 'the/a' and the modified noun huis 'house' in phi-features. In addition, as mentioned in section 3.2.2. in BCS the attributive form (LF) plav-i: 'blue' is interpreted as definite, specific (the modified noun with the LF is interpreted as definite) while the short form (SF) plav 'blue' is associated with an indefinite interpretation. 
(66) a. (jedan) plav kisobran

(one) blue-SF umbrella

'a blue umbrella' b. plav-i: kisobran

blue-LF umbrella

'the blue umbrella'

In addition to the definite interpretation of the noun phrase in which the LF occurs, Aljovic (2010) points out that the LF also agrees with the modified noun - so in BCS, the LF (attributive form) performs two functions; definiteness and agreement. The paradigm of adjectives in the selected European languages show that they all possess free predicative adjective which systematically fail to reduplicate their attributive adjectives. The predicative forms are not made into a nominal to enable modification, the change in the forms of the predicative forms in the attributive positions is as a result of other parameters, namely, agreement and definiteness.

\subsection{Summary}

There is an interplay between the internal syntax of NAMs (their internal architecture) and their (NAMs) external syntax (how they (NAMs) attach to the modified noun) to which I turn in the next chapter. The present chapter has expatiated the internal structure of NAMs in Ògè and extends the analysis of NAMs to Yorùbá. It reveals that the predicative forms are prefixed with the nominalizer $i$ to form the attributive modifier; in the case of Ògè, the roots are reduplicated when prefixed with the nominalizer ( $i$-NAMs), while in Yorùbá, the initial consonant of the predicative roots is copied to the initial position of the attributive modifier. It was shown that this process is necessary because in Standard Yorùbá unlike some of its dialects, a high tone does not occur at the initial position of a word. In both languages, syntactic and morphological approaches are advanced for the analysis of the internal structure of the attributive noun over a phonological one for two 
reasons (i) in Yorùbá, it has been established in the literature that the high tone and not necessarily the vowel $i$ is the sole reason for the change in category observed in the attributive noun (and also in gerunds, focused and relativized items). Every scholar who has looked at the phenomenon of the internal structure of gerunds, agrees that the $i$ is a default vowel in this environment (ii) for Ògè, I proposed that the $i$-prefix is with an exponent of RED which stands for 'reduplication' in the context of the Nominal Attributive Modifier and this is why it is able to nominalize the reduplicated segment in attributive position. 


\section{Chapter 4: The external syntax of Nominal Attributive Modifiers (NAMs) in Ògè}

\subsection{Introduction}

The focus of this chapter is to examine the external syntax of NAMs to answer the question of what the structural location of NAMs in the nominal phrase of Ògè is? Because of the nominal nature of attributives as established in chapter 3 , it is important to analyze the structural location of attributives in the noun phrase of Ògè in relation to the modified noun. Several languages have shown that the combination of a nominal attributive modifier with the modified noun forms a noun-noun compound, however, the data in Ògè show that despite the nominal status of NAMs, the string NAMs $>$ noun is a modification expression (see section 4.3. for evidence in support of this). The chapter is organized as follows: Section 4.2. examines NAMs in argument positions. Section 4.3. discusses evidence against a noun-noun compound for the string 'NAMs >noun' while section 4.4. and 4.5. present the syntactic analysis of NAMs. Section 4.6. gives the summary of the chapter.

\subsection{NAMs in argument positions}

In the preceding chapter, I established the nominal status of NAMs. In this section, I give evidence that the directionality of the attachment of NAMs determines the function performed by the NAMs in a noun phrase in Ògè. Section 4.2.1. provides evidence which shows that NAM can replace a noun in a possessive expression while section 4.2.2. shows that unlike its base form, NAM is grammatical in a genitive expression. I propose that NAMs are head of the nominal phrase when it is a genitive or possessive expression, but that they are modifiers otherwise. 


\subsubsection{NAMs in possessive expressions}

In many known languages, adjectives are grammatical in nominal positions, in this sense, both predicative and attributive adjectives. The aim of this section is to show that just like adjectives in languages with an open class of words, NAMs are grammatical in a canonical nominal position. ${ }^{25}$ However, it is important to note that the root from which NAM is derived is not grammatical in such contexts. In addition, the main claim in this section is that NAMs are the head when they occur in either a genitive or a possessive expression but not in attributive positions. To begin with, consider the example in (1-2).
(1)a. éswé ísínsín
house black
b. *éswé sín house black
'Black's house' or the house which belongs to Black
(2)a. ìvéve ígbègbè
food small
'small's food.'
b. *ìvéve gbègbè
food small

The NAMs ísínsin 'black' and ígbègbè 'small' are used as a proper name in examples (1a2a), something like an appellation. The ungrammaticality of the 'b' versions of the examples show that the predicative forms are not allowed in such contexts which further supports the categorial difference established between the two forms 'attributive and the predicative form' To be more explicit, NAM can be used to refer to an individual who performs the role of a possessor in the noun phrase.

\footnotetext{
${ }^{25}$ A typical example of the position of the noun is the subject and the object positions as shown in (1).
$\begin{array}{lll}\text { (1) a. Tade dà ìsi } & \text { b. Tade dà íhoho } & \text { c. *Tade dà ho }\end{array}$ Tade buyyam Int:Tade buywhite
'Tade bought a/the yam.' 'Tade bought a/the white one.'

As shown in (1b), ihoho 'white/whiteness' replaces isi 'yam' in the object position. It is important to note that the predicative form is derived is not grammatical in this position.
} 


\subsubsection{NAMs in genitive expressions}

The morpheme -'s or the preposition 'of' is used to mark genitive in English: 'the girl's shirt' versus 'the shirt of the girl'. It is standardly assumed that the relationship between two nouns is termed 'genitive.' Some languages allow overt realization of case known has genitive case to mark genitive on arguments as in German (Hartmann \& Zimmermann, 2002). In Ògè, case realization on arguments is covert which mean that the structural position or the function of an argument determines the case of the argument. ${ }^{26}$

(3)a. ígbègbè ìkári éswé

small DET house

'smallness of the house' b. íyẹ̀nyẹ̀n ìkári àyẹ̀

sweet DET soup

'sweetness of the soup' (4)a. íhòhò ígé éswe

white DEM house

'whiteness of the house' b. ígogoígé áchọ́

old DEM cloth

'oldness of the cloth'

In (3-4), NAMs mark genitive in the noun phrase. In such sentences, I propose that NAM is the head as shown in the illustration in (5).

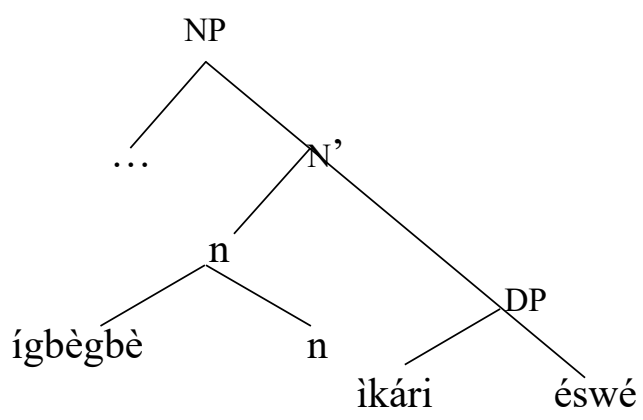

\footnotetext{
${ }^{26}$ In Ògè, just like in English, nouns do not bear a morphological case but the position of the noun in the noun phrase determines the case of the noun (either nominative (subject position), accusative (direct object position)) and so on.
} 
The NAM ígbègbè 'small' occupies the head position of the little $n$ in (5). The base form from which NAMs are derived cannot occur in this position as the ungrammaticality of (6) and (7) show.

(6)a. *gbègbèikári éswe small DET house

(7)a. *ho íge éswe white DEM house b. *yẹ̀n ikári àyẹ̀ sweet DET soup

b. *go ígé áchọ́

old DEM cloth

More explicitly, if igbègbè 'small' for example is a noun, and not an adjective, it will explain why an Ògè speaker can say ígbègbè íkári éswe yè mi, 'I like the smallness of that house' but an English speaker cannot say '*I like the small of that house' The hypothesis that igbègbè is an adjective crashes on the fact that in Ògè, the so-called 'adjective' can be used as an argument expression (specifically in this case as the subject of a sentence, but English cannot).

The external syntax of NAMs given in this section supports the fact that the structural architecture of NAMs allows NAM to be able to perform more than a function in the nominal domain: a head or a modifier. Descriptively, in Ògè, NAM functions as the head of the phrase if an intervening element is overt between NAM and the noun ( $8 b)$ or if NAM occurs in a post-nominal position (8a).
a. N-NAM
Possessive
b. NAM - D - N
Genitive
c. $[\mathrm{nP}[\mathrm{n}$ NAM [DP D N]]]
Head status of NAM

The relevant argument for my analysis here is the occurrence of NAM on the little $n$ in genitive expressions as shown in (5) and the ungrammaticality of the root in both 
possessives and genitives expressions. For the syntactic analysis of NAM in attributive position (modification function), see sections 4.4. and 4.5.

\subsubsection{NAM in isolation in Yorùbá}

This section provides two different contexts in which NAMs are grammatical in isolation without the modified noun. This means that NAMs are grammatical in a typical argument position.
(9) Tádé mún dí-dùn,
ó fi t-í-tóbi sílẹ̀.
Tade take C-NMLZ-sweet, he put C-NMLZ-big LOC down
'Tade took the sweet one, he left the big one.'

In the example in (9), two readings are possible (i) noun ellipsis and, (ii) pure argument reference in context. Imagine the context in (10).

(10) a. Background: A pen was missing from a bag (apparently, a thief has stolen the pen from a bag containing two different colors (white and black) of pens. The question in (10b) was asked from the owner of the bag. The response in (10c) is grammatical in context. The response was taken from Awobùlúyì (2013:39). The background was created by me for exemplary purposes.
b. Question: Kí-ni olè náà jí? WH-thing thief SAL steal
'What did the thief steal?'?
c. Answer: Olè náà jí dúdú,ó fi funfun sílẹ̣.
Thief SAL steal black HTS put white LOC. down
'The thief stole the black one and left the white one.'

\footnotetext{
${ }^{27}$ náà is analysed in Ajíbóyè (2005) as a salient marker (SAL).
} 
(11) a. Background: At a party, the celebrant was very excited to see her guests, the comment in (b) is grammatical about the celebrant.

b. Bí ó se ń kí g-í-ga ni ó ń kí k-ú-kurú

As HTS do PROG greet C-NMLZ-tall be HTS PROG greet C-NMLZ-short

'As she greets the tall, so she greets the short'28

The same analysis applies to NAMs in Ògè. NAMs in Ògè are grammatical in argument positions as shown in sections 4.2.1. and 4.2.2. It is worthy of note that the predicative form from which the attributives are derived do not occur in such contexts. In this section, I show that NAMs are grammatical without the modified noun, in other words, NAMs can occur in argument positions just like underived nouns. In the next section, ample evidence is given to show that NAMs plus Noun is a case of a nominal modification and not a nounnoun compound.

\subsection{NAMs, a Noun-Noun compound?}

A close observation of the combination of NAMs and the modified noun raises the question of a structure closely related to a noun + noun compound, hence N-N compound. The main claim in this section is that the structure, NAM + Noun is a nominal phrase and not a N-N compounding structure. For the purpose of this work, I take compounding as a way of combining two old words to form one new one as in chalk + board $=$ a type of board as opposed to a marker-board. To start with, I provide a case study of a language in Africa which exhibits a clear case of Modifier + Noun compounding as clearly shown in Soninke a West Mande language, this is the focus of the next section.

\footnotetext{
${ }^{28}$ This example is like the one used in Awobùlúyì (2013), I deliberately changed the words in the sentence because of personal reasons, here is the example;

(i) Bí ó se $\mathrm{n}$ pa k-í-kurú l'ó $\mathrm{n}$ pa g-í-gùn

As HTS do PROG kill C-NMLZ-short FOC- HTS PROG kill C- NMLZ-tall

'As he kills the short, so he kills the tall.'
} 


\subsubsection{Evidence for a Modifier + Noun compounding}

In this section, I review Creissels's (2016) work on Adjective noun incorporation in the Mande language family. Creissels (2016) argues that the way to modify a noun with an attributive adjective in Mande and Gur language families is through the integration of attributive adjective and noun into a word construction. Creissels looked at the phenomena of compounding in noun + attributive in three language families; Sub-saharan languages, Mande languages and Gur languages. For the purpose of this section, I examined the phenomena of noun + adjective compound in the Mande language families. According to Creissels (2016), Soninke, a West Mande language, exhibits a clear case of morphological compounding.

Nominal modifiers have the same syntactic distributions as noun in Soninke and they are morphologically like nouns. They can combine with - $n$ (a definite marker) (12a-13a), they can be pluralized (12b-13b), and they can occur without an overt marker (in a singular form).

a. Ń dà sélìnyê-n qóbó.
1SG TR chicken- D buy
'I bought the chicken.'

$$
\begin{aligned}
& \text { a. Ń dà sélín-qúllè-n qóbó. } \\
& \text { 1SG TR chicken-white- D buy } \\
& \text { 'I bought the white chicken.' }
\end{aligned}
$$
b. Ń dà sélìnyû-n qóbó. $1 \mathrm{SG}$ TR chicken. PL- D buy 'I bought the chickens.'

In (12), the citation form of the noun sélinyê 'chicken' is marked for definiteness with the suffix $-n$ while in (12b), it is further marked for plural. The examples in (13) show that the adjective qúllè 'white' can equally be marked for definiteness (13a) and plural (13b). Creissels (2016:5) argues that in Soninke, all attributive adjectives form compounds with 
the noun they modify. This is clear from the examples in (13); adjectives in Soninke are capable of inflecting for 'definiteness' and 'plural' even in the presence of an overt head noun.

Creissels further supports his arguments for a compounding analysis for the linearization of an adjective plus a noun with the N-N compound in Soninke as shown in (14). The examples in (14), is a N-N compound in Soninke. The ungrammaticality of (14b $\& 15 b)$ show that the citation form of 'village' which is dèbê is not grammatical in a N-N compound when it combines with gùmê 'chief' Similarly, the citation form of the noun sámáqqè 'snake' (15b) is not grammatical when it is used in a N-N compound.
a. dèbì-gùmê
b. *dèbê-gùmê
'village-chief'
'village-chief'
(15) a. sámán-pátè
'snake-skin'
b. *sámáqqè-pátè
'snake-skin'

The characteristics of the noun in N-N compound in Soninke is the same as when it is modified by an adjective. The examples in (16) shows that the citation form of the noun sélingê 'chicken' cannot occur when it is modified by the attributive adjective qúllè 'white'.

$\begin{array}{rll}\text { (16) *Ń } & \text { dà } & \text { sélìnyê-qúllè-n qóbó. } \\ \text { 1SG } & \text { TR } & \text { chicken-white-D buy }\end{array}$

The phenomena of noun modification in Soninke shows that the modified noun needs to appear in a certain form before it could be modified by an attributive adjective. This is clearly not the case in Ògè as I show in section 4.3.2. 
Following the discussions in this section, in the next section, I show that $\mathrm{N}-\mathrm{N}$ compounding in Ògè is difficult to tease apart from NAM + noun compounding on the surface and that the difference between a N- N compound and a NAM plus noun structure could be expatiated in syntax.

\subsubsection{NAM + noun, not a case of compounding in Ògè}

A close observation of the data presented so far shows that it is difficult to differentiate between a NAM + noun compound and a NAM + noun modification on the surface in Ògè unlike Soninke. The only solution to this puzzle is to take solace in syntax. I discuss two characteristics of NAM + noun in Ògè which clearly distinguishes them from a $\mathrm{N}+\mathrm{N}$ compound.

First, I show that the order of modifiers in N- N compounds in Ògè is strict, while this is not the case in NAM - noun constructions. Some examples of N - N compounding in Ògè are given in (17).

(17) a. Éswe-úsín - Palace

House-king

b. Úwan- ọ́kọ-úsín - Prince

child-male-king

c. Úwan-eléchúi-usin - Princess

Child-female-king

The ungrammaticality of the examples in (18) shows that the ordering of items in a N-N compound in Ògè is strict. In addition, the examples in (18) don't become grammatical even if a prosodic break is introduced (unlike the combination of NAMs plus Noun as I show in the example in (19)). 
(18)
a. *úsín-éswe
b. *úsín-ọ́kọ-úwan
c. *úsín-eléchúi-úwan
king-house
king-male-child
king-female-child

In a NAM plus noun expression on the other hand, it is grammatical to reorder NAMs as shown in the examples in (19b). The basic order is given in (19a) while the reordered version is the example in (19b). It is interesting to note that when NAMs are not in their canonical form, a pause is required after the pronunciation of the first NAM before the second and the third NAMs. This pause indicates an emphasis on the first NAM which further indicate that the focus is specifically on it rather than the following NAMs.
a. ígbààji ígbègbè ísinsìn ópú
b. ígbègbè ígbààji ísinsìn ópú
good small black dog
small good black dog
'a/the good small black dog'
'a/the SMALL, good black dog'

Second, syntactic rules cannot apply to the internal structure of NAM + noun combination. NAMs can occur in a nominal position without the modified noun as shown in (20).
a. Tunde dà íhòhò
Tunde bought white
b. Tunde dà íhòhò áchọ́
'Tunde bought the white one'
Tunde bought white cloth
'Tunde bought the white cloth'

As shown in (20), ihòhò 'white' occurs as the object of the verb dà 'buy'. As is well known, this position is a typical object position often occupied by a noun. Intuitively, the speaker is aware that there is an object which the modifier refers to. However, in a $\mathrm{N}-\mathrm{N}$ compound, ellipsis cannot apply to the noun (21). If this happens, the result is outright ungrammaticality or a change in the intended meaning. 
(21) a. Éswe-tusín - house

House-

b. Úwan- ọ́kọ -úsín - male child

Child-male-

c. Úwan-eléchúi-úsín - female child

Child-female-

In other words, ellipsis can apply to the modified noun in a NAM $+\mathrm{N}$ expression while it is not possible for ellipsis to apply to the modified noun in a $\mathrm{N}-\mathrm{N}$ compound. The hypothesis that the combination of a NAM + noun is a nominal compound crashes on the fact that the modified noun is not liable to elision.

\subsection{A syntactic analysis of NAMs in attributive positions}

This section presents the syntactic analysis of NAMs in attributive positions. The proposal for the status of NAMs in a modification expression is that of an adjunct. Previous analyses of the sort explained in this section have argued that modifiers occupy a designated specifier position of a functional phrase (Cinque 2010, 1995, 1994) while Abney (1987) amongst others argues that nominal modifiers are heads of a nominal phrase. In a different vein with ample evidence, Bernstein (1991) argues that nominal modifiers are best analyzed as adjuncts in a nominal expression in languages. To begin with, section 4.4.1. discusses the specifier analysis of adjectives while 4.4.2. discusses the head analysis of nominal modifier. Section 4.4.3. carries out the previous analyses of adjectives as adjuncts. Section 4.4.4. presents the syntactic analysis of NAMs. Specifically, I introduce the theory of the label for the concatenation of NAMs + Nouns as laid out in Zeijlstra (2020) which is further supported by the semantic and syntactic analysis of attributive adjectives in Truswell (2004). 


\subsubsection{A specifier-based analysis (Cinque 2010)}

According to Cinque's (2010) analysis, adjectives and relative clauses are underlyingly prenominal in both Germanic and Romance languages while adjectives in Romance canonically appear post-nominally unlike in German. Cinque argues that adjectives are merged in the specifier position of the functional projections dominating the NP. The specifier-based analysis offers a way of handling the permissible number of adjectives in nominal phrases by stating that a limited number of adjectives stems from a finite number of FPs between the DP and an NP as shown in (22).

(22) a.

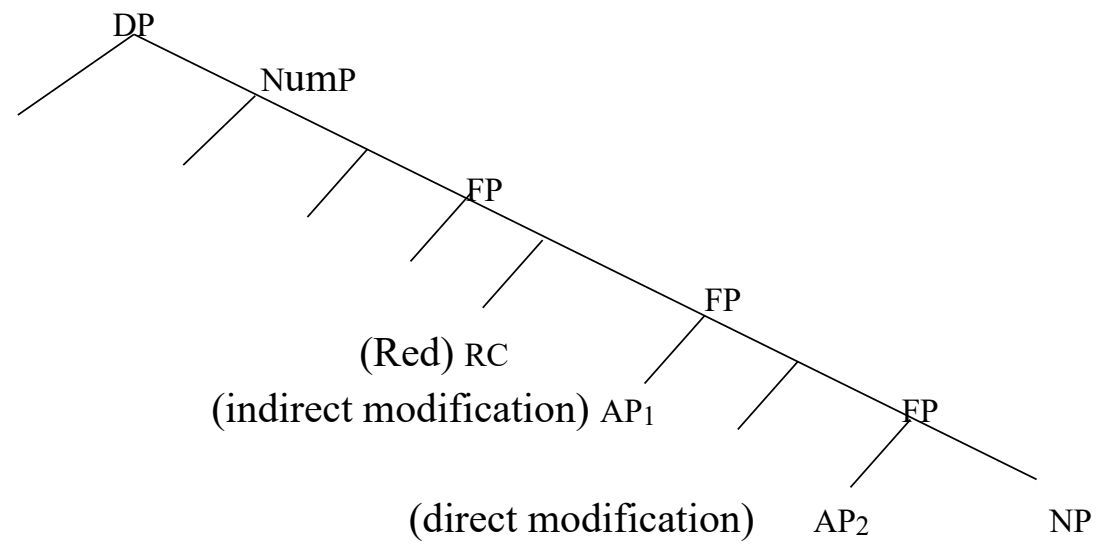

(Cinque 2010:34)

As indicated in the structure in (22), a finite number of FPs implies a finite number of specifiers available as generation sites for adjectives which is related to the two different syntactic types of adjectives: direct modification (DM) and indirect modification (IM) adjective. According to Cinque, DM adjectives are specifiers of functional heads while IM are reduced relative clauses that are generated in the specifier of a higher functional projection. According to this analysis, DM adjectives are closer to the noun while IM adjectives are farther away from the head noun. Cinque shows that the post nominal placement of adjectives on the surface may be derived by means of NP-raising as (22b) illustrates. 
b.

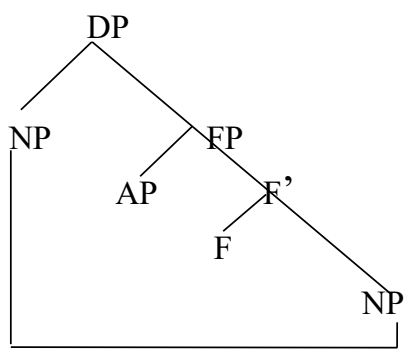

It is important to note that in the specifier-based analysis, adjectives are analyzed as lexical items that are generated as left-hand specifiers of FPs between the DP and an NP. In the next sub-section, I discuss the head-analysis of adjectives and I show that NAMs are best analyzed as adjuncts rather than heads of a syntactic expression.

\subsubsection{Head Analysis}

Starting with the analysis of adjectives as heads according to Abney (1987), I examine the analysis of Truswell (2004) who posits that adjectives are best analysed as a lexical category which blurs the line between a head and an adjunct (a hybrid analysis). Since the focus of this chapter is on the syntactic analysis of NAMs, I will abstract away as much as possible from the semantic analysis proffered in Truswell. The hybrid analysis of Truswell is important for the syntactic account of NAMs in one significant way; as I show in section 4.5., it makes explicit, the intricacies involved in the linear order of NAMs and the modified noun.

In the head-based analysis according to Abney (1987), attributive adjectives are heads taking the NP as complements, in other words, the adjective is a head that c-commands the NP. In expressions such as (23), it is argued that the prenominal adjective does not take a complement.

(23) a. a proud father

b. *a proud of his son father 
c.

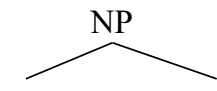

A NP

proud father

(Modifiers as heads)

However, arguments abound in the literature of the assumption that prenominal adjectives are restricted to taking the NP as its complement is falsified on the premise that a lot of languages allow its prenominal adjectives to take a PP complement, (Delsing (1993); Svenonius (1992) for Swedish, Cinque (2010) for Bulgarian and Greek). The authors argue that the complementation possibilities of prenominal adjectives are not uniform cross-linguistically. Invariably, the languages in which adjectives take complements block the argument in favour of an analysis of adjectives as heads in the extended projection of the noun.

In a similar but different vein, Truswell (2004) argues that all attributive adjectives are functors, taking an $<\mathrm{e}, \mathrm{t}>$ nominal argument. Here, heads are analysed in terms of their compositional semantic function. In his terms, a functor is taken to be a head which takes its complement as an argument and outputs the complement's semantics with an extra free variable position or index. The notion of projection is spelt out in (24) according to Truswell (2004:102).

(24) Merger of a head and a complement

Under standard consideration, the head projects.

This is because the head may introduce a free variable position, which determines what can be merged next in the specifier position. Also, the notion that the head projects is seen in the notion of the functional sequence. This can equally be well captured by saying that the next head to be merged in the functional sequence is dependent on the index or variable introduced by the current head. 
Based on the predictability of syntactic heads as presented in (24), Truswell argues following Chomsky (1998) that attributive adjectives are functors. This argument is justified because the output of a functional application is of the same type as the sister. If syntactic headedness is predictable, it can be omitted from the representation of the derived syntactic object (Chomsky 1998). Following this line of reasoning, Truswell argues that the relationship between an attributive adjective and its sister is headcomplement rather than 'DPs' or any close-off item such as may be found in specifier position. Attributive adjectives are of an identity type $\langle\alpha, \alpha>$, and so the output of functional application is of the same type as the sister, which makes it appear as if the nominal projects. However, Truswell noted two objections to this analysis thus:

(25) a. adjectives as heads taking NP complements complicates the complementselection process, or functional sequence;

b. pre-nominal adjective could be internally complex, with productive syntactic formation options involving degree markers such as 'very'

Truswell tackles the objection of functional sequence based on the transparency of adjectives; adjectives are semantically of type $<<\mathrm{e}, \mathrm{t}><\mathrm{e}, \mathrm{t}>>$ which makes the linear order of Adj-N identical to those of the noun. ${ }^{29}$

(26) a. a red car

b. a car

c.

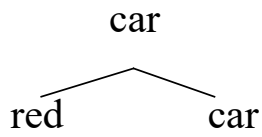

As exemplify in (26), 'red' merges with the noun 'car', but the structure retains the same

\footnotetext{
${ }^{29}$ Here, the argument is that adjectives are underlyingly of type $<e, t>$. In this case, adjectives are of two types; predicative adjective are $<\mathrm{e}, \mathrm{t}>$ while in attributive position, attributive adjectives are type-shifted to $<<\mathrm{e}, \mathrm{t}><\mathrm{e}, \mathrm{t}>>$.
} 
label as the noun. The omission of the adjective 'red' in (26b), does not result in ungrammaticality but only implies a change in meaning. Second, concentrating on the use of degree modifiers such as 'very' with adjectives, Truswell argues that the notion of the head is defined in terms of its function. Take for instance the representation in (27).

(27) That is [very big]]

Abstracting from the technical details of the string in (27), 'very big', as presented in Truswell, Truswell shows that a head is syntactically complex. (cf. Truswell 2004:104) for the full analysis of the complex form of the adjective as a head).

For the analysis of NAMs in this work, I follow the arguments proposed for the objection in (25). The answer to the objection is closely related to my analysis of NAMs as adjuncts. I claim that syntactically, NAMs are adjuncts in the extended projection of the noun and that in all contexts, NAMs are merged in a direct relationship to the NP. NAMs do not modify the DP neither do they allow a degree modifier such as 'very'.

\subsubsection{Adjunction analysis of attributive adjectives}

The proponents of adjectives as adjuncts include Bernstein (1991); Bosque-Picallo (1996), Svenonius (1993) among others. Here, adjectives are treated as elements with phrasal status which adjoin to either the maximal projection or to an intermediate projection.

(28)

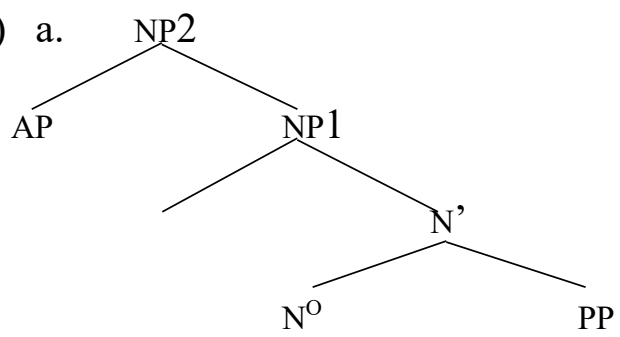

Adjectives as adjuncts to NP

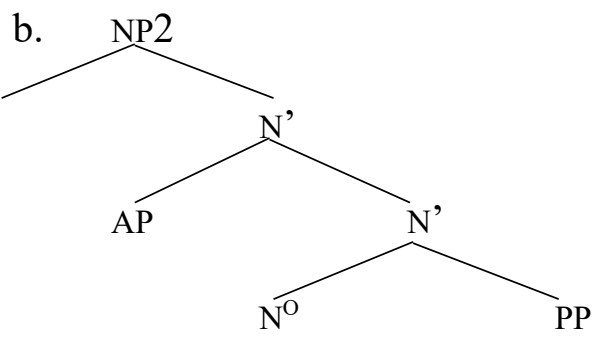

Adjectives as adjuncts to bar-level 
c.

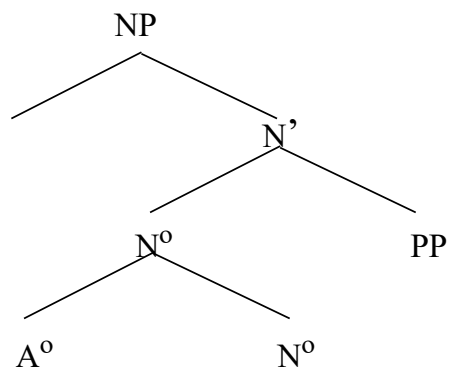

Adjectives as adjuncts to the $\mathrm{N}-\mathrm{head}^{30}$

Some of the crucial shortcomings of the analysis of adjectives as adjunction include the fact that it does not proffer provision for the mechanism to regulate the directionality of the attachment of adjectives in case of multiple adjectives. In addition, it also fails to account for the linear order of adjectives in cases where two or more adjectives are stacked. In Ògè, the linear order of NAMs is not of utmost importance because in some cases, the semantic of the sentence remains unchanged when NAMs are re-ordered.

\subsubsection{Optionality of NAMs in attributive positions}

As shown in the preceding sections, NAMs are categorially different from the predicative forms. The base form from which the attributive form is derived is itself not an adjective but a stative verb while the result of nominalization is not an adjective but an attributive noun. I present the examples in (29) and (30) to show the modification function of NAMs in Ògè.

$$
\begin{aligned}
& \text { a. ikári ígogoópú } \\
& \text { DET old dog } \\
& \text { 'the old dog' }
\end{aligned}
$$

$$
\begin{aligned}
& \text { b. ìkári íhòhò éswe } \\
& \text { DET white house } \\
& \text { 'the white house' }
\end{aligned}
$$

\footnotetext{
${ }^{30}$ This analysis is the most unpopular account of adjectives out of the three types of adjunction analysis mentioned above. Sigurdsson (1993) defended this analysis for Modern Icelandic. It is generally assumed that adjectives that adjoin to a nominal head also have the status of heads themselves. For the purpose of the analysis of NAMs in this work, it is enough to show that adjectives are capable of adjoining to different layers in the extended projection of the noun.
} 
(30) a. ígé ígbègbè úghwọ

DEM small stick

'that small tree' b. ígé ísinsín ópú

DET black dog

'that black dog'

As shown in the paradigm in (29-30), NAMs in Ògè are restricted to the pre-nominal position and are obligatorily followed by the modified noun as the ungrammaticality of the reverse orders in (31-32) show.
a. *ikári ópú ígogo
DET dog old

(32)
a. *ígé úghwọ ígbègbè
DEM stick small

$\begin{array}{ccc}\text { b. *ikári } & \text { éswe } & \text { íhòhò } \\ \text { DET } & \text { house } & \text { white }\end{array}$
b. *ígé ópú ísinsín
DET dog black

Based on the characteristics of NAMs; namely that they are grammatical in a canonical nominal position, I propose that the categorial feature of NAMs is an [NP]. NAMs have the semantics of adjectives but NAMs are nominal. Having this as a background knowledge, I present a preliminary structure in (33) (under the traditional assumptions of syntactic derivation of adjectives (adjuncts)) for the concatenation of the merger of NAMs plus Noun in Ògè for the expression in (29a).

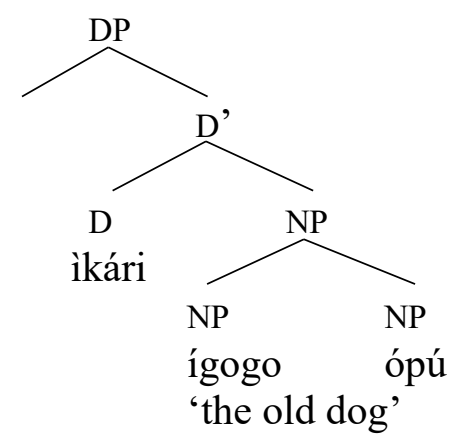

A preliminary structure for NAMs I 
In a modification expression, the grammatical string is 'NAMs plus noun' with no intervening element(s). The previous section showed that the change in the order of NAMs plus noun to noun plus NAMs could only result in a change in meaning: from a modification expression to a possessive expression. In cases, where a determiner occurs between NAMs plus noun string, then a genitive interpretation is forced. An interesting point however is that in both possessives and genitives, the presence of NAMs is required for the expression to be grammatical (34).

a. éswé *(ísínsín)

house black

'Black's house' or the house which belongs to Black

b. ìvéve *(ígbègbè)

food small

'Small's food.' or the food of small, the food that belongs to small'

If the NAMs isinsin 'black' and igbègbè 'small' are omitted from the examples in (30), one of the following happens; ungrammaticality or change in the intended meaning. In the same vein, in genitives, the overt realization of NAMs is obligatory as shown in (3-4) repeated here in (35-36).

a. ígbègbè ìári éswé

small DET house

'smallness of the house'

(36)
a. íhòhòikári éswe
white DET house
b. ígogoikári áchọ́
'whiteness of the house'
old DET cloth
'oldness of the cloth'

b. íyẹ̀nyẹ̀n ikári àyẹ

sweet DET soup

'sweetness of the soup' 
The examples in (37-38) show that without the NAMs, the expressions are not in any way related to a genitive expression. In such expressions like (35-36), NAMs are obligatory because they are the heads of the expressions.
$\begin{array}{cc}\text { a. *ikári } & \text { éswe } \\ \text { DET } & \text { house }\end{array}$
b. *ikári àyẹ̀
DET soup
'the house'
'sweetness of the soup'

(38)
a. ígé éswe
b. ígé áchọ
DEM house
DEM cloth
'the house'
'the cloth'

On the other hand, NAM in a pre-nominal position in Ògè is a modifier and its presence is optional as shown in (39-40). This assumption is further expatiated in section 4.5.
a. ìkári ́́gөgo ópú
DET $\quad \operatorname{dog}$

'the dog'

(40)

a. ìkári ŕgbègbè éswe
DET house
'the house'
b. ìári íhòh̀̀ éswe
DET house

'the house'

The expressions in (39-40) show that the absence of NAMs does not translate to ungrammaticality, rather, it translates to a change in meaning. Based on the interpretation of the expressions in (39-40) without the overt realization of NAMs, I propose that NAMs are not obligatory in a nominal expression in Ògè. I assume that NAMs are only needed in such contexts to convey more information about the modified noun. The claim that I pursue in this section among others are: NAMs are not obligatory; NAMs are involved in 
feature checking according to the minimalist program; NAMs are not selected by the modified noun; NAMs iterate (41).

\section{(41) Sadé pu ígbegbe íwaji ísinsin òdí size $>$ quality $>$ color \\ Sade kill small bad black rat \\ 'Sade killed a small bad black rat'}

In the remainder of this section, I present the syntactic analysis of the merger of NAMs plus the noun in Ògè. The application of the analysis of Zeijlstra (2020) to NAMs allows for a syntactic equivalent of the semantic account proposed for attributive adjectives in Truswell (2004). As it will become clear in the subsequent sections, the main claim will be that in a syntactic string, all features on lexical categories must project except the selecting and the selected feature. Based on current syntactic theories as proposed in Zeijlstra (2020) which extensively discusses the concatenation of adjuncts plus nouns, a revision to the structure in (33) is given in (44) that shows the intricacies involved in the merger of NAMs plus nouns in Ògè.

\subsubsection{Problems with the label of adjuncts in the Minimalist Program}

In this section I present the debate surrounding the output of the derivation of adjuncts in the literature. Svenonius (1994), posits that adjectives in attributive positions do not change the syntactic category of the elements to which they are merged, in as much as this is true, the reason for this conclusion is not settled in the literature. Importantly though, the syntactic label of adjuncts is still a problem in the Minimalist Program as the debates in some work show Carmack and Breheny (1994); Seely (2006:183); Sportiche (1994), (1995); Hornstein (2009) and more recently, Zeijlstra (2020). The debates have to do with the fact that adjuncts are not subcategorized for, so the question remains if 
adjuncts are not involved in selection, what is the label for the concatenation of the head plus an adjunct? In a bid to solve this problem, Uriagereka (2003) posits that adjuncts undergo a different type of merge which he calls pair merge. In pair merge, if A is an adjunct, and $\mathrm{B}$ is it host, then B projects its label. ${ }^{31}$ Labels were integral to the theories from which the Minimalist Program arose. ${ }^{32}$ In Hornstein's (2009) view, adjuncts are different from complements and specifiers; the building of the latter two requires that the output be labelled whereas the concatenation of adjuncts is only necessary to receive a proper interpretation. On a different view, Collins (2002) and Seely (2006) analyzed the output of adjuncts as label less, specifically, Seely advocates for the elimination of labels while Bruening $(2010,2013)$ claims that adjuncts select the category of the phrase that they adjoin to. To be more explicit about the status of labelling, Chomsky (1994) posits that if label is part of Merge, then, the label of Merge $(\mathrm{X}, \mathrm{Y})$ is either $\mathrm{X}$ or $\mathrm{Y}$, there is no other alternative of derivation according to Minimalist assumptions. Cecchetto \& Donati (2010) assume that a label is a set of features that percolate from a head and trigger further computations. This implies taking $\{\mathrm{X}, \mathrm{Z}\}$ as a unit for the purpose of further computations, which in turn determines its syntactic behavior and interpretation at the sound-meaning interfaces. See (42) for illustration.

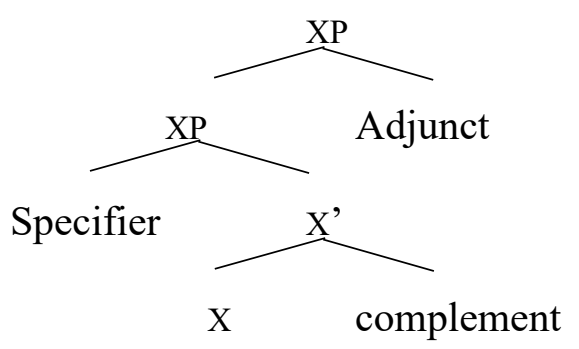

(Adger 2003:88)

\footnotetext{
${ }^{31} \mathrm{Cf}$; Chomsky (1995a et seq) for the two separate operations for pure merge 'set merge and pair merge where pair merge is a process of adjunction in which the head does not project; rather, the most recent projection of the head is replaced by a two segment category.

32 Phrase Structure Rules (Chomsky 1975) of transformational generative grammar \& X-bar theory (Chomsky 1970, Jackendoff 1977) in the Government \& Binding era (Chomsky 1981) were formulated in terms of LABELS.
} 


\section{b. [X-MAX YP $[\mathrm{X}-\mathrm{MAX} X P]]$}

The concatenation of the head ' $\mathrm{X}$ ' and its complement yield the label ' $\mathrm{X}$ ' (an intermediate bar-level) while the concatenation of the specifier and the bar-level is labeled 'XP'. The question remains why the merger of XP and Adjunct yield another XP. Adger also notes this problem in his book when he said, 'the mechanism by which adjuncts are incorporated into the phrase structure is still a major research topic'. The major problem is the fact that the maximal projection ' $\mathrm{XP}$ ' is not supposed to project any further after merging with the adjunct (XP plus adjunct an instance of two maximal projections). This shortcoming of the projection by selection approach was also noted in Zeijlstra (2020), according to him, $\mathrm{X}-\mathrm{MAX}$ which is assumed to be a maximal projection projects further after the merger with the adjunct in (42b).

In a different view, Chomsky (2000) posits that MERGE is a structure-building operation that comes in two forms: set merge and pair merge; set merge is inherently asymmetric in which case the lexical item with the selectional feature projects its label while pair merge refers to elements that are not sub-categorized for. The question arises as to why merge should be divided into two separate operations? As noted in Hornstein (2009:86), pair merge introduces a redundancy in narrow syntactic operations. In the same vein, Stockwell (2016) noted that the analysis of adjuncts as carried out by Chomsky is uneconomical in the sense that it introduces three operational complications: pair merge, simplify and redundancies. However, I depart from the assumptions in Stockwell (2016), who supports the idea that the optimal label of a syntactic derivation is paramount to the selection in the attempt to form the next syntactic object. The motive behind the syntactic label for NAMs as adjuncts in this chapter is not to determine the next merged object but to make explicit the intricacies of the merger of NAMs plus the modified noun. 
This section proceeds as follows; section 4.4.6. presents the problems of the traditional analysis of adjuncts for NAMs, section 4.4.7. discusses a solution to the problem in the sense of Truswell's (2004) while 4.4.8. proceeds with the adopted analysis for this chapter as presented in Zeijlstra (2020).

\subsubsection{Problems of the traditional analysis of adjuncts for NAMS}

Following the assumptions in Adger (2003) where the category features correspond to the major word classes: N, V, P, the modified noun in Ògè is replaced with $[\mathrm{N}]$ and NAM is [N] based on the evidence shown in section 4.2. Accordingly, there is the need to differentiate between the two lexical items with the feature $[\mathrm{N}]$; a head and its modifier (NAM). As standardly assumed within the Minimalist program, adjuncts are phrasal, they are optional, and they are not selected for. The concatenation of the head noun and a lexical item like NAM is made possible through the mechanics of adjunction which inserts a phrasal object into another phrasal object at its outermost level (Adger 2003:89).

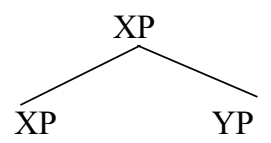

Therefore, the concatenation of NAM with the modified noun would look like the structure in (44).

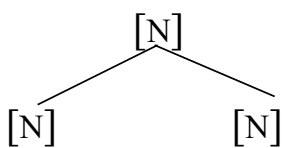

\section{A preliminary structure for NAM II}

An immediate problem with this analysis is connected to the problem of recognizing the projected feature; the head $[\mathrm{N}]$ or the adjunct $[\mathrm{N}]$ ? An immediate seemingly solution is to specify one of the features with a selectional feature: [N, uN], but it is a well-known fact 
that adjuncts are not selected for neither do adjuncts select. Another possible solution is to annotate the features with numbers thus; $[\mathrm{N}] 1$ and $[\mathrm{N}] 2$ as shown in (45).

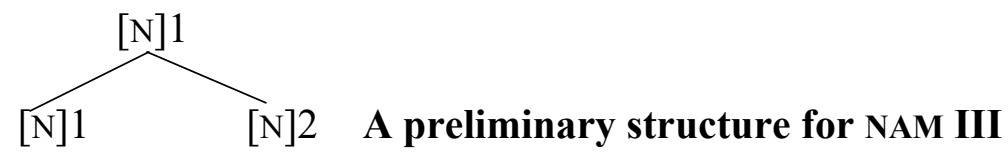

The structure in (45) clearly shows that the percolated feature is the lexical item on the left with the feature $[\mathrm{N}] 1$. However, an interested reader will be prompted to ask the question why the lexical item on the right with the feature $[\mathrm{N}] 2$ does not project? Why does the concatenation of $[\mathrm{N}] 1$ and $[\mathrm{N}] 2$ yield the label $[\mathrm{N}] 1$ ? Please note that in the example above, I ignored the selectional requirement of a determiner, and as a result this is omitted from the example. The focus here however is why the concatenation of two maximal projections (i.e., NP and 'AP') which are not supposed to project any further yielded the label $[\mathrm{N}] 1$.

As a first step to solve this puzzle, a quick survey of the two-selected solutions proposed for the merger of the sort discussed here are presented in the sections below.

\subsubsection{Truswell (2004)}

Abstracting from the view of adjectives as specifiers of rigidly ordered and distinct heads, Truswell posits two different semantic analysis for attributive adjectives: an adjunct within the nominal projection or the noun as an argument of the adjective. However, Truswell argues for a hybrid analysis for attributive adjectives; attributive adjectives are theoretically situated between a head and an adjunct. As will become clear in this section, theoretically, the features of the daughters contribute to the label of the mother. For the purpose of this section, I will discuss the semantic account of attributive adjectives as an optional item in a syntactic category, after which I will give a syntactic account of 
attributive adjectives as heads. The importance of the analysis as presented in Truswell (2004) for the analysis of NAMs in this chapter is that it makes explicit the intricacies involved in the merger of attributive adjective plus noun. In addition, the semantic account of the string Adj-Noun gives support to Zeijlstra's assumptions in section 4.4.8. on the inherent feature of attributives/adjuncts in languages. First, Truswell argues that an Adj-Noun group is semantically opaque. Invariably, the string Adj-N can function as a bare noun in a syntactic structure. Second, modification is assumed to be recursive because the type of the noun remains unchanged by merging an adjective while the modification is entirely optional. Third, all attributive adjectives are functors. It is important to introduce some of the theoretical terms as used in Truswell;

(i) JOIN - following the assumptions in Chierchia and Tuner (1988); Baker (2003), Truswell argues that JOIN is a type-shifting operator whose main function is to select an adjective, outputting a function from nominals to nominals as (46) shows.

(ii) Same/Sameness - this is used in the example in (46) to restrict attributive adjectives to noun phrases.

Truswell classifies adjectives into two types, predicative and attributive adjectives. Predicative adjectives are of type $<\mathrm{e}, \mathrm{t}>$ while attributive adjectives are of type $<<\mathrm{e}, \mathrm{t}>,<\mathrm{e}, \mathrm{t}>>$. For a predicative adjective to function as an attributive adjective, then an operator is required to change it to a type $\langle<\mathrm{e}, \mathrm{t}\rangle,<\mathrm{e}, \mathrm{t}>>$. The ungrammaticality of the example in (47) further supports the fact that an $\langle<\mathrm{e}, \mathrm{t}\rangle,\langle\mathrm{e}, \mathrm{t}\rangle\rangle$ adjective is restricted to attributive positions and that it doesn't take degree modifiers like 'very'

(46) a. That car is big

b. A very big car 
(47) a. *That car is former

b. *A very former car

The operator required to change an adjective from one type of adjective to the other is termed 'JOIN' as laid out in (48);

(48) JOIN: merging with adjectives first:

$\operatorname{JOIN}(\lambda x . A(x))=\lambda N \lambda x .(A(N ; x)))_{j}^{33}$

Where:

A is the property denoted by the adjective;

$\mathrm{N}$ is the property denoted by the noun (or Adj- $\mathrm{N}$ group);

A $(\mathrm{N}(\mathrm{x}))=1$ iff $\mathrm{x} \in$ the set constructed based on $\mathrm{N}$, determined by the property of A relativized to $\mathrm{N}$;

$i$ is the index assigned by same ${ }^{\circ}$ to NP (or the index assigned as a result of merging an earlier adjective);

$j$ is the index assigned by same ${ }^{o}$, but updated to reflect the updating of the property denoted by $\mathrm{N}$ through the merger of A.

The syntax and semantics of attributive adjectival modification as presented in (48) above is along the lines of the syntactic structure in (49). Here, JOIN is assumed to merge with the adjective after which the output of the merger merges with the noun and further yields the label red(car).

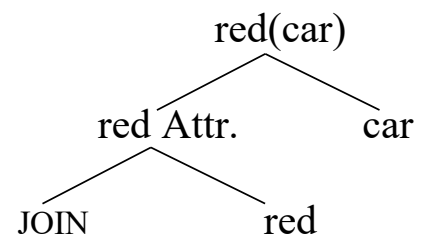

\footnotetext{
${ }^{33}$ For clarity, I will restrict my explanation of JOIN to Truswell's Option 1 JOIN. I refer to it as Option 1 JOIN because, Truswell gave an additional Option which he calls My JoIN, Option 2. Since this is not relevant for my analysis, I will ignore it in this work.
} 


$$
\begin{aligned}
& \text { 'red' }=\lambda x \cdot \operatorname{red}(x) \\
& \text { 'car' }=\lambda x \cdot \operatorname{car}_{i}(x) \\
& \operatorname{JOIN}(\lambda x \cdot \operatorname{red}(x))=\lambda P \lambda y \cdot \operatorname{red}\left(P_{i}(y)\right)_{j} \\
& \lambda P \lambda y \cdot \operatorname{red}\left(P_{i}(y){ }_{j}[\lambda x \cdot \operatorname{car} i(x))\right]=\lambda y \cdot r e d\left(\lambda x \cdot \operatorname{car}_{i}(x)[y]\right)_{j}=\lambda y \cdot r e d\left(\operatorname{red}\left(\operatorname{car}_{i}(y)\right)_{j}\right.
\end{aligned}
$$

Formulating the semantics of attributive adjectives in this way allows for the recursiveness, as shown in the representation above, plus the noun is constant when it is modified by an adjective. In the structure, there is no requirement for the merger of the attributive adjective unlike the need for a clausal structure to contain an argument. Invariably, modification by an attributive adjective is entirely optional. However, the operator JOIN introduced in the structure requires an $<\mathrm{e}, \mathrm{t}>$ element to modify 'JOIN can only take nominals as complements, because only these nominals have a standard of sameness.'

On the other hand, noting the problem associated with the syntactic analysis of attributive adjectives as adjuncts in the literature and as outlined here in this chapter in section 4.4.5., Truswell argues that a hybrid analysis is suitable for the syntactic status of attributive adjectives. As a starting point, Truswell makes a distinction between the following notions: interpretable and uninterpretable features, head, complement and specifier. Following the assumptions in Chomsky (1995); uninterpretable features exist for the purpose of movement (they force movement) while interpretable features have to do with the need to satisfy the requirement of one of the merged elements. ${ }^{34} \mathrm{~A}$ head is defined as a functor which takes its complements as an argument and outputs the complement's semantics with an extra free variable or index. A specifier on the other hand is a complete 'close off' argument to the function denoted by its sister, which then

\footnotetext{
${ }^{34}$ Basically, the distinction between an interpretable and uninterpretable feature as presented here in Truswell is related to, one, compositional semantics of an utterance, two, inducing movement.
} 
projects with a variable position bound by the semantics of the specifier. The distinction between these notions is paramount in this theory because of two important things that are necessary to keep in mind; (i), it makes explicit the differences between semanticallydriven merge and non-semantically driven merge, in this case, merge happens either for the purpose of movement or for the purpose of semantics (the semantic requirement to be merged into the structure) (ii), the semantic distinction between head, complement and specifier allows for a semantic correlate of the syntactic notion of projection.

Taking this a step further, Truswell argues that heads are functors, taking the complements as arguments and outputting a derived syntactic object with the semantics of the complement, plus an extra free variable or index (100). This means that elements (with interpretable features) merged at the specifier positions are arguments of the complements (which is its sister). Therefore, under this analysis, semantically, both sisters project and by extension, the same thing happens in syntax. This is clear because the label of the mother-node is determined by both daughters. To make this point explicit, Truswell argues that attributive adjectives is one of the cases where Chomsky's claim that 'Merge occurs to satisfy the requirements of one of the daughters' is not true. In the next section, I present a further analysis of this sort as presented in Zeijlstra (2020) where he argues that projection happens as a result of feature checking. The analysis of Zeijlstra is closely related to the analysis presented in this section because it makes no distinction between a head and an adjunct in syntax. In addition, Truswell adopts a hybrid analysis for attributive adjectives using both semantic and syntactic arguments to show that both daughters are involved in projection. 


\subsubsection{Zeijlstra (2020)}

Chomsky (1986), (1995b), proposed that the principle of full interpretability (FI) posits that unvalued uninterpretable features must be deleted before reaching the interfaces. This means; uninterpretable features may cause the derivation to crash after valuation. According to this proposal, interpretable features ([iFs]) are features that are part of the intersection of the two sets (formal and semantic features) as shown in (50) and therefore may both participate in syntactic operations and receive an interpretation at LF. Uninterpretable features on the other hand are features that are only formal, and not semantic in nature and therefore cannot receive an LF -interpretation. This is represented in (50) as presented in Chomsky (1995).

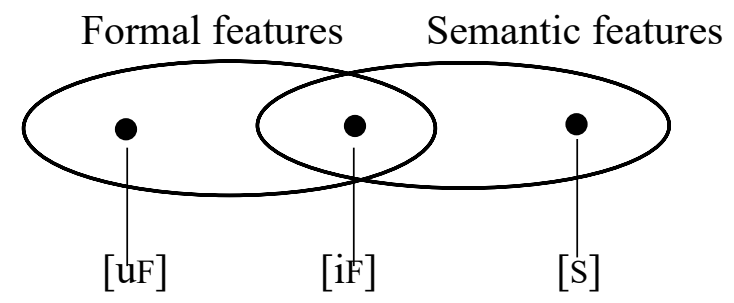

Zeijlstra on the other hand, argues that interpretable features can check off uninterpretable features independent of semantics. For instance, uninterpretable features are checked and deleted in syntax before they get to LF in expressions where a lexical item with a plural form gets a singular interpretation, this shows that formal features and semantic features operate independent of each other as shown in (51). Based on this evidence, Zeijlstra argues that both interpretable and (un) interpretable features should be replaced by dependent and independent features or just categorial features. This assumption is in line with Zeijlstra (2014) who argues that the set of (un) interpretable features does not intersect with the set of semantic features, as proposed in Chomsky (1995). The structure in (51) explains this further. 


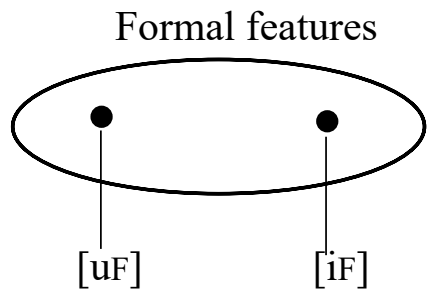

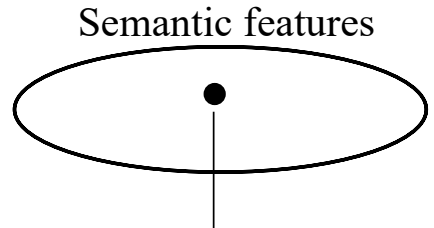

$[\mathrm{s}]$

As mentioned above interpretable features can check off uninterpretable features independent of semantics features. The structure in (51) shows exactly this and then the interpretable feature takes on the role of semantic features by checking and deleting matching uninterpretable formal features to their semantic properties. Under this theory, c-selectional features is reduced to already existing features (interpretable [iF] and uninterpretable features $[\mathrm{uF}]$ ) that encode syntactic dependencies (uninterpretable feature are dependent on interpretable features for proper interpretation). C-selection does not make explicit the properties that are overt on a lexical item, instead, it relies on how a lexical item fits into a sentence. Zeijlstra (2014) supports the representation in (51) further with the following proposal for acquisition algorithm;

(52) a. Assume a 1:1 correspondence between morphemes and semantic content.

b. If some morpho-syntactic element $\alpha$ manifest the presence of some semantic context $\mathrm{F}$, but cannot be assumed to be the carrier of $\mathrm{F}$ itself, then assign a formal feature $[\mathrm{uF}]$ to $\mathrm{S}$.

c. Assign [iF] to all morphosyntactic elements that introduce the semantic context that is manifested by [uF]. If no overt morphosyntactic element is responsible, assume some covert element to be present that carries the semantics of $\mathrm{F}$ and therefore, should be assigned [iF].

d. Assign [iF] to all those elements that are responsible for the rest of the grammatical occurrences of $[\mathrm{uF}]$.

Based on the proposal in (d), Zeijlstra argues that [iF] does not denote that some element must have the semantic property of $\mathrm{F}$. The only requirement that is needed is that it is 
learnable that some element is able to check some [uF]'s feature. Invariably, dependent features encode dependencies on other features: a feature [uD] encodes dependency on an element carrying [D]. ${ }^{35}$ Independent feature determines the categorial status in a traditional way: a verb has a feature [V], a noun has a feature [N] etc. ${ }^{36}$ Rule 1 and Rule 2 explain this further;

Rule 1: Rule 1: Let A and B be two sets of formal features. If A merges with B, for any pair $[\mathrm{F}]-[\mathrm{UF}]$, such that $[\mathrm{F}] \in \mathrm{A}$ and $[\mathrm{uF}] \in \mathrm{B}$, or $[\mathrm{F}] \in \mathrm{B}$ and $[\mathrm{uF}] \in \mathrm{A}$ neither $[\mathrm{uF}]$ nor $[\mathrm{F}]$ percolates; all other features do percolate.

(Zeijlstra 2020)

(53) a.

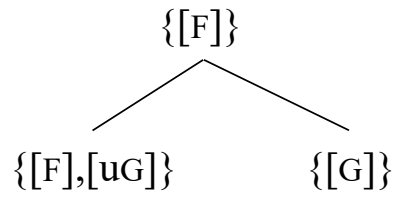

b. $\{[\mathrm{F}],[\mathrm{UK}]\}$

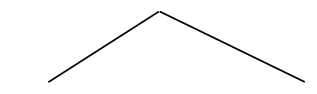

$\{[\mathrm{F}],[\mathrm{uG}]\} \quad\{[\mathrm{G}],[\mathrm{uK}]\}$

The tree in (53a) shows that the dependent feature [uG] and the independent feature [G] are cancelled against each other and the independent feature [F] becomes the label of the tree. The tree in (53b), shows that it is possible for a dependent feature which is not checked to percolate. Zeijlstra adds that, this can only occur if and only if feature checking is involved in the merger, [uG] checks [G]. This is spelt out in Rule 2.

Rule 2: $\alpha$ merges with $\beta$ iff at least one featural dependency is resolved as a result of this merger (Zeijlstra 2020).

Building on the insights of Adger (2003), which assumes that upon Merge, every feature of both merged elements percolate, unless a pair of matching (un)interpretable features

\footnotetext{
${ }^{35}$ Under this analysis, dependent features are restricted to syntactic operations. For this reason, syntax gets rid of dependent features before it gets to the interfaces.

${ }^{36}$ Independent features give us information about the properties of the lexical item i.e., a number on the noun or tense on the verb. To be more explicit, dependent feature bears a ' $u$ ' feature.
} 
stand in a sisterhood relation; then neither of these two features percolate. The assumptions in Zeijlstra's analysis of projection by selection is like categorial selection: adjectives adjoin to a projection of $\mathrm{N}$ while adverbs adjoin to other projection of other categories (this could not be semantic selection but must be a form of categorial selection). Selection must be part of the syntax proper and could not be delayed until PF.

The assumptions in Rule $1 \& 2$ are the basic assumptions underlying the syntactic structure of the external syntax of NAMs in Ògè. Basically, I adopt the mechanisms of dependent and independent features where both formal features determine the syntactic behavior of lexical items. In this proposal, merger needs to fulfill a featural dependency; a selectional feature encodes a requirement to be merged with an element that carries an independent feature. Here, it is assumed that merge is only licensed if at least one feature is discharged (Chomsky 2000:133, 2005:6). It is also the case that the algebra of merge is the only means by which selection features can be checked (that is, there is feature percolation, rather than agreement at a distance). Basically, the argument in section 4.5. is twofold; (i), NAMs are introduced into a syntactic structure for the purpose of modification (ii) there is syntactic dependency relationship between the NAM and the modified noun. ${ }^{37}$ The assumption is that, although NAMs are merged as adjuncts but that both the NAM and the modified NP/N are involved in feature selection and feature checking in Zeiljstra's (2020) term.

\footnotetext{
${ }^{37}$ The analysis proposed here is in the sense of categorial grammar in which an item depends on the existence of an adjacent item for its survival. This analysis could be extended to any relationship between an adjunct-sister sequence such as Adv- V sequence as well. As shown in section 4.4.7., the intriguing part of this analysis is that it allows for the transparency of the merger of the modifier with the modified noun.
} 


\subsection{NAMS are dependent on the modified noun (Selectional restrictions of NAMS)}

This section shows that merge must involve feature checking, in Zeijlstra's term, everything projects except the selecting and the selected features. In addition, I argue for the replacement of every category in Ògè by a more primitive feature. I give an account of the labelling algorithm of NAMs as adjuncts according to the alternative labels for adjuncts as laid down in (Zeijlstra 2020). ${ }^{38}$ The discussion in this section is an updated analysis of NAMs as adjuncts in the syntactic expression of Ògè (as given in sections 4.4.4. and 4.4.6.).

I repeat the examples in (29-30) as (54-55) for convenience. As argued earlier and as shown by the ungrammaticality of the examples in (56-57), NAMs are restricted to the prenominal position.

a. ìkári ígogo ópú

DET old dog

'the old dog' b. ìkári íhòhò éswe

DET white house

'the white house'

(55)

a. ígé ígbègbè úghwọ

DEM small stick

'that small tree' b. ígé ísinsín ópú

DET black dog

'that black dog'

(56)
a. *ikári ópú ígogo
b. *ikári éswe íhòhò
DET dog old
DET house white
a. *ígé úghwọ ígbègbè
b. *ígé ópú ísinsín
DEM stick small
DET dog black

\footnotetext{
${ }^{38}$ In Minimalist Program, every category is thought of as a primitive feature: Adverbs carry [ADV], PP carry [P], verbs carry [v] based on Chomsky $(1970,1981)$.
} 
In addition to this, no element(s) is permitted to intervene between a NAM and the modified noun.
a. *ikárí́gogolàvì ópú
b. *ikárí́hòhòlàvì éswe
DET old very dog
DET white very house

(59)
a. *ígé ígbègbè làvì úghwọ
b. *ígé ísinsín làvì ópú
DEM small very stick
DET black very dog

The sequence NAM $>$ Noun or NAM $>$ NAM $>N A M>$ Noun is the acceptable string as shown in

(41) repeated here in (60).

(60) Sadé pu ígbegbe íwaji ísinsin òdí

size $>$ quality $>$ color

Sade kill small bad black rat

'Sade killed a small bad black rat'

The data in (54-60) reveal three important facts about NAMs; NAMs are recursive, NAMs are restricted to a nominal domain, NAMs in modification expressions are not complex (because it is not possible to have the string [[very NAMs] N]] in Ògè, rather, the acceptable string is [[NAM N] very]] as shown in (61));
(61) ígé íhòhòáchọ́ làvì
DEM white cloth very
'that very white cloth'

In the spirit of Zeijlstra's re-analysis of (un)interpretable features, the data in (58-59) further reveals that NAMs are dependent on nouns and that the dependency must be local. For the syntactic analysis of NAMs, I adopt the mechanisms of feature checking as proposed in Zeijlstra (2020) where interpretable formal features are taken to be pure 
formal features that have the capacity to check off uninterpretable features but lack any semantic interpretations. ${ }^{39}$

In Zeijlstra's proposal, once the features of the mother and the daughter are known, it is possible to determine the featural status of the sister as shown in (62).

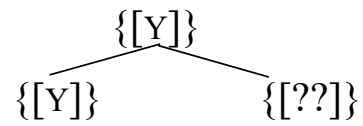

b.

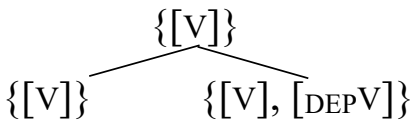

Given that in (62a), ' $\mathrm{Y}$ ' is the head and the other sister is an adjunct, then the featural status of the sister will be [Y, uY] (adjunction stands in a configuration with the modified item). In a derivation with two maximal projections as in (62b), here illustrated as the concatenation of the VP plus Adverb with the feature [V], [DEP V]; the only percolating feature is the $\mathrm{V}$ on the adjunct. (For clarity sake, in this work, I represent the ' $u$ ' of the dependent feature as 'DEP' while 'INDEP' is used to represent an independent feature). ${ }^{40}$ This is in line with the assumptions of Truswell as discussed in section 4.4.7., when he argues that both the specifier and its sister are simultaneously involved in feature percolation and that the specifier being a 'close off' element percolates independent of the sister. The only difference between the assumptions in Zeijlstra's and Truswell is that the output of derivation carries the feature of one of the inputs (Zeijlstra (2020) while the output bears both features of the specifier and its sister (Truswell 2004).

Following Zeijlstra, I assume that NAMs inherently have the feature sets $\{[\mathrm{N}, \mathrm{DEPN}]\}$ while the modified noun has the feature set $\{[\mathrm{N}]\}$. The structure in (63) shows that NAM merges with a feature set $\{[\mathrm{N}]\}$ which it modifies, the $\{[\mathrm{N}]\}$ feature of the noun and the

\footnotetext{
39 This is a different approach from Chomsky who proposed an intersection for the two 'formal features and semantic features' see the example in (50).

${ }^{40}$ However, this is not relevant since an independent feature is represented in the sense of an interpretable feature with an 'iF' or just ' $F$ '.
} 
$\{[\mathrm{DEPN}]\}$ feature of NAM do not percolate. The only feature that percolates is the $\{[\mathrm{N}]\}$ feature on NAM.

\section{DP internal selection in Ògè}

(63) a.
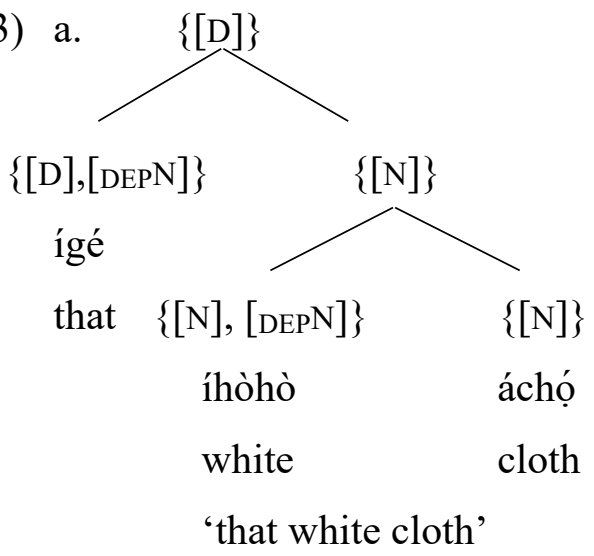

b. $\{[\mathrm{D}]\}$

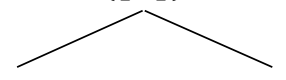

$\{[\mathrm{D}],[\mathrm{DEPN}]\} \quad\{[\mathrm{N}]\}$

ígé that

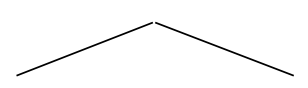

$\{[\mathrm{N}],[\mathrm{DEPN}]\} \quad\{[\mathrm{N}]\}$ ígbègbè úngwọ small tree 'that small tree'

This means that the right sister (the modified noun with the feature $[\mathrm{N}]$ ) is a maximal projection which is the highest projection of the feature [N]. NAMs with the feature sets $\{[\mathrm{N}],[\mathrm{DEPN}]\}$ are also a maximal projection of the modifier; the feature $\{[\mathrm{N}],[\mathrm{DEPN}]\}$ indicates the adjuncthood or the dependency relation of NAMs and the noun in Ògè (63a $\&$ b). The $\{[\mathrm{N}],[\mathrm{DEPN}]\}$ feature on NAM shows the dependency relation between the modified noun and NAM in a modification expression in Ògè. Like the analysis proposed in Truswell, the approach adopted in this analysis to the merger of heads plus adjunct suggests that the two maximal projections (NP plus adjunct) are both involved in feature checking.

I support the fact that NAMs (adjuncts) are not selected for by the modified noun, but I assume that there must be feature checking between NAMs and the modified noun in a sisterhood relation as shown by the ungrammaticality of NAMs when it occurs in a 
different context from a nominal context. Further evidence for this assumption comes from the fact that, NAMs cannot be modified by PPs unlike the predicative forms. ${ }^{41}$

(64) a. Ìgo

Sade yẹ̀n sí Sọlá

Stomach Sade sweet to Sola

'Sade is happy about Sola'
b. *İgo
Sade í-yẹ̀n-yẹ̀n
sí Sọlá
stomach sade NMLZ- sweet-sweet to Sola

There remains an open question as to why NAMs does not occur with degree modifiers if we assume that NAMs are not a head in a modification structure. At this point, tentatively, we can conclude that;

$$
\begin{aligned}
& \text { Because NAMs do not occur with degree modifiers and } \\
& \text { because they are optional and recursive, it is not plausible } \\
& \text { that NAMs are the heads in a modification expression. } \\
& \text { It is plausible therefore, to conclude that NAMs are adjuncts. }
\end{aligned}
$$

\footnotetext{
${ }^{41}$ NAMs do not occur in an environment where it could be modified by the PP. Only the predicative roots are grammatical in such contexts. Further evidence for this is that in such contexts where PPs can modify NAMs, it is obvious that such contexts are predicative constructions in which NAMs are never found.
} 


\subsection{Summary}

In this chapter, I have carried out the analysis of the external syntax of NAMs in Ògè. For a better understanding of the motive behind the analysis of NAMs, in chapter 3 , I looked at the internal structure of adjectives in some European languages and noted that, adjectives in the selected languages form an open class of lexical items even though the predicative and attributive adjectives are morphologically different. This observation further supports the fact that both LFs and SFs are found in canonical adjectival position while this is not the case in Ògè. Further to this, evidence is provided in Yorùbá (a closely related language to Ògè) to support the structure of attributive modifiers in Ògè. I showed that all attributive modifiers are derived from an underlying predicative form in Yorùbá.

I claim that as for the external syntax of NAMs, they are adjoined to the modified noun which further supports the fact that NAMs modify NPs and not DPs in a nominal expression in Ògè. Based on the inherent property of NAMs ' $N$ ' - I propose that NAMs are dependent on nouns for grammaticality and that the inherent feature of NAMs are [N, DEPN]. With ample supports both from a syntactic and semantic perspective, NAMs are analyzed as dependent element; NAMs depends on the modified noun with an inherent feature [N, DEPN]. An analysis of NAM as adjunct to the modified noun is plausible in two ways: it explains the morphological difference observed in the predicative form and the attributive form and it shows the mode of modification (A direct modification relation) between a NAM and the modified noun. 


\section{Chapter 5: Number marking in Ògè}

\subsection{Introduction}

This chapter discusses the various strategies of number marking in Ògè. Most importantly, plural marking in languages has received a lot of attention from scholars with varied analyses. For example, Ritter (1991) analyses number in Hebrew as an inflectional affix which is associated with a functional head (Num) while Wiltschko (2008) analyses plural marking in Halkomelem as a non-inflectional plural marking in which the presence of the plural morpheme is not obligatory. Several scholars have supported the claim in Wiltschko (2008) on the different positions of occurrence of the plural morphemes in languages in relation to the obligatoriness versus optionality of overt plural marking: Persian (Ghomeshi, 2003), Amharic (Kramer, 2012), Yucatec Maya (Butler, 2011) and Korean (Kim \& Melchin, 2018). ${ }^{42}$

This chapter discusses the various systems of number marking in Ògè with specific focus on the plural interpretations of the noun. It proposes that oturro, is sensitive to the plural interpretations of the noun and that it instantiates a D-head. This proposal accounts for two things: first, it demonstrates that otúro does not cooccur with ikári and ikin (both elements are found in singular contexts), and second, it shows that nouns that are interpreted as plural are construed as definite plural. Using the feature specification mechanisms as laid out in (Adger 2003, 2010; Chomsky 1995, 2000, 2001), this chapter provides further evidence that the plural interpretation of the noun in Ògè comes from the Num-head in syntax.

\footnotetext{
${ }^{42}$ In each of the languages mentioned, the authors argued for a different layer within the nominal phrase for the plural morphology: Ghomeshi (2003), claims that plural marking is connected to the Q/DP layer within the Persian noun phrases (p.71). Kramer (2012) adds to the growing literature on multiple syntactic locations for plurality, and she provides evidence that irregular pluralization strategies in Amharic are the realizations of $\mathrm{n}[+\mathrm{pl}]$ (p.235). Butler (2011), analyzes plural in Yucatec Maya as an adjunction to the DP layer while Kim \& Melchin (2018), analyzes the plural marker -tul in Korean as an adjunct to the $n$-layer in the nominal spine.
} 
The chapter provides answers to the research questions in (1):

(1)(i) How are nouns marked for plural in Ògè: semantically or syntactically marked.?

(ii) Is there the need for the projection of a Num(ber) phrase in the nominal spine of Ògè since it is well-known that languages with a non-inflectional plural marking system do not project a NumP in their nominal expression.?

(iii) Is otúro associated with interpretations other than the plural interpretation of the noun.?

In attempting to provide the answers to the questions in (1), this chapter argues for the need for a NumP projection within the nominal spine of Ògè and shows that the element in D takes a value for number from Num and that otúro is inserted in D in the case of a plural definite interpretations of the noun. It is a common knowledge in the literature that in languages with a non-inflectional plural marking (Wiltschko 2008; Kramer 2015; Butler 2011; Kim \& Melchin 2018) the NumP is not projected in the nominal spine. This chapter shows that the Num-head is required in Ògè in order to bear the number feature specifications associated with number interpretations of the noun.

The chapter proceeds as follows: sections 5.1.1-5.1.2. present the data and the theoretical approach adopted for the analysis of number marking in Ògè. Section 5.2. discusses the previous analyses of plural marking in languages; mainly, plural marking that is associated with a functional head (5.2.1.) and modifying plural marking languages (5.2.2.). Section 5.3. discusses the interactions between the system of plural marking in Ògè and the plural marking systems in the languages that were discussed in section 5.2. while sections 5.4. and 5.5. present the syntactic analysis of number marking in Ògè. Section 5.6. gives the general discussions of the analysis proposed for the strategies of plural marking in Ògè in this chapter and section 5.7. concludes the chapter. 


\subsubsection{The Data}

This section presents the data that is discussed in this chapter. First, bare nouns (BNs) in Ògè are ambiguous between a singular and a plural interpretation (2). A BN could be interpreted as (in)definite singular (2a'-b'), bare plural (2a“'-a'), indefinite non-specific plural $\left(2 a^{\prime \prime}-b^{\prime \prime \prime}\right)$ but not definite plural $\left(2 a^{\prime \cdots}-b^{\cdots \cdots}\right)$.
(2)a. Í ri ópú.
b. Í dà àga.
$1 \mathrm{SG} \quad$ see $\quad \operatorname{dog}$
1SG buy chair
a.' = 'I saw a/the dog.'
b. '= 'I bought a/the chair.'
a." = 'I saw dogs.'
b. '= 'I bought chairs.'
a. ${ }^{\prime \prime}=$ I saw some (unspecified) dogs
b. '"='I bought some (unspecified) chairs.'
a. ${ }^{\cdots} \neq$ I saw the dogs
b. ${ }^{\prime \prime}=$ 'I bought the chairs.'

Second, nouns are not morphologically marked for plural in Ògè, rather the overt realization of the article which is otúro translates to the plural interpretation of the nouns.
(3)a. Í rì òtúro ópú.
b. Í dà òtúro àga. $1 \mathrm{SG} \quad$ see $\quad$ PL dog 1SG buy PL chair
a.' = I saw the dogs.'
a. " = 'I saw some specific dogs.'
a. ${ }^{\prime \prime} \neq$ 'I saw some dogs.'
b.' = 'I bought the chairs.'
b. " = 'I bought some specific chairs.'
b. ${ }^{\prime \prime} \neq$ 'I bought some chairs.'

The presence of otúro can be interpreted as definite plural (3a'-b'), indefinite specific plural (3a“'-b") but not as indefinite non-specific plural (3a“"'-b“"). It is important to note that when oturro occurs with the noun, the noun is unambiguously interpreted as plural. Third, when ikári/ikin is overt, the noun is obligatorily interpreted as singular (4). As shown in chapter 2, section 2.3. of this dissertation, the articles, ikári/íkín/òtúro do not cooccur as indicated by the ungrammaticality of the examples in (5). 
(4)a. Í rì íkín/ìkári ópú $1 \mathrm{SG} \quad$ see $\mathrm{INDEF} / \mathrm{DEF}$ dog

a. ' = 'I saw a/the dog.'

a. " $={ }^{*}$ 'I saw the dogs.'

(5)a. *Í rì òtúro/íkín/ikári ópú $1 \mathrm{SG} \quad$ see $\quad \mathrm{PL} / \mathrm{INDEF} / \mathrm{DEF} \quad \operatorname{dog}$ b. Í dà íkín/îkári àga 1SG buy INDEF/DEF chair

b. '= 'I bought a/the chair.'

b. ' = *'I bought the chairs.'

b. *Í dà òtúro/íkín/ìkári àga 1SG buy PL/INDEF/DEF chair

Fourth, in some contexts the plural interpretation of the BN is closely linked to the form of the verb that is used. As shown by the interpretation of the example in (6a), go is the plural form of $g b i$ 'give'. In (6a), the noun is obligatorily interpreted as plural while (6b) receives a singular interpretation.

(6)a. Sade gọ áchó yan Tade Sade give cloth to Tade 'Sade gave some cloths to Tade.'

*'Sade gave a cloth to Tade.' b. Sade gbì áchó yan Tade Sade give cloth to Tade 'Sade gave a cloth to Tade.'

*'Sade gave some cloths to Tade.'

Thus, this chapter shows that the overt realization of otúro refers to a plural interpretation of the noun, while ikári and ikin translate to the singular interpretations of the noun. BNs are unspecified for number while in some contexts they are obligatorily translated as either singular or plural. This chapter reveals six important facts about the system of plural marking in Ògè:

(7)a. Ògè possesses BNs and bare plurals (just like in English: 'I like bears'; 'Bears are scary').

b. Nouns in Ògè have general number.

c. Plural marked nouns are interpreted as plural only, singular nouns are interpreted as singular only while BNs could mean one or more than one. 
d. There are no pluralia tantum but there are meaning-mis-matches of unmarked nouns for number and not form-meaning mismatches (see section 5.3.3. for more details).

e. NumP is compatible with languages in which nouns have general number (contra Wiltschko 2008).

f. Plurality interacts with definiteness and animacy.

\subsubsection{Theoretical Background}

The framework that is adopted in this work is the minimalism theory of syntactic feature specifications as laid out in (Adger 2003, 2010; Chomsky 1995, 2001, 2002). Adger (2003) defines features as properties of syntactic atoms which allows features to enter relationships with other features, for example, an interpretable feature is said to be able to enter a relationship with a counterpart feature that is not interpretable. The example in (8a) is not grammatical because the verb does not Agree with the singular noun 'the man.'

(8) a. *the man chuckle

b. the men chuckle

The grammaticality of $(8 b)$ shows that the verb form and the plural form of the noun is compatible: plural noun agrees with a plural verb.

Morphosyntactic features are the basic building blocks of syntax and their interactions account for the observable syntactic phenomenon. Adger \& Harbour (2008) describe syntactic features as features which have morphological expression and syntactically influence distribution, such as Agree. In this work, following Chomsky (1995), and Zeijlstra (2020), I take Agree as an operation which checks whether the attributes of an unvalued and a valued feature match, and then value the unvalued one to be the same as the one it is agreeing with. ${ }^{43}$ Take for instance, if the Number feature on Num is PL and

\footnotetext{
${ }^{43}$ In this sense, Agree does not just check whether a dependent and an independent feature match by checking the dependent one rather, Agree is a feature driven mechanism between a probe and a goal which have a matching feature.
} 
the number feature on $\mathrm{D}$ is unvalued for number, represented as ' $\mathrm{D}[\mathrm{uNum}:]$ ', what Agree does is that it gives a value to the unvalued uninterpretable number feature on $\mathrm{D}$, which will then be written as D[uNum: PL]. This is further illustrated in (9) and expatiated with the structure in (10).

\section{(9) Agree \\ $\mathrm{X}[\mathrm{F}: \mathrm{val}] \ldots \mathrm{Y}[\mathrm{F}]$}

The value from [F:val] is copied to $\mathrm{Y}[\mathrm{F}:]$, resulting in $\mathrm{X}[\mathrm{F}: \mathrm{Val}] \ldots \mathrm{Y}[\mathrm{F}: \mathrm{Val}]$

The features $\mathrm{X}[\mathrm{F}: \mathrm{val}]$ and $\mathrm{Y}[\mathrm{F}:]$ in the configuration in (9) help to distinguish between the features that seek a value from those features that do not require a value. For instance, the [u Num:_] on D indicates a dependency relation between the D-head and the Numhead while the empty space after the colon on the uninterpretable feature on Num, shows that the Num needs a value either PL or SG. This is an instance of structure enrichment where the features present on one node are spread onto other nodes, 'Agree' is assumed to establish a Probe-Goal relation, the goal bears an inherent feature which are specified on the features on the probe. In this analysis, the features on the probe are derived from the features on the goal through agreement. For the analysis adopted in this chapter, Dhead is the probe while the Num-head is the goal.

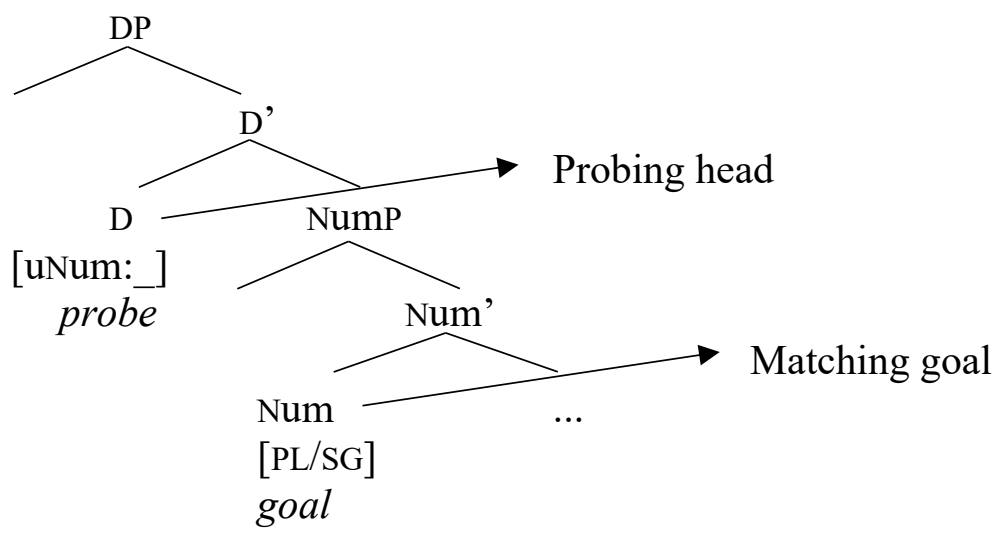


The uninterpretable unvalued number feature on D gets its value from the goal 'Numhead'.

The main theoretical assumptions in this work is that the Num-head is projected in the syntax of Ògè. Against common knowledge in the literature that in languages with noninflectional plural marking (Wiltschko 2008; Kramer 2015; Butler 2011; Kim \& Melchin 2018), the NumP does not project, this chapter shows that the Num-head is required in Ògè to bear the number feature specifications associated with the number interpretations of nouns (see section 5.3. and 5.4., for more details on this). In the remainder of this chapter, I provide adequate explanations to the six facts about the plural marking systems, in Ògè that I listed in (7). First, I start by giving an insight into the previous discussions and analyses of plural marking in languages. Most importantly, the main point of the discussions in section 5.2. is to show that, although nouns in Ògè are bare but that the morphological elements associated with number interpretation of nouns in Ògè are derived through the agreement between the D-head and the Num-head. ${ }^{44}$ Section 5.3. provides the relationship between oturro and the plural systems in the languages that are discussed in section 5.2 .

\subsection{Previous analyses of plural marking in languages (two standard views)}

As mentioned in section 5.1., this section presents the two systems of plural marking in languages as found in Ritter (1995) for head-marking plural system and Wiltschko (2008) for modifying-plural system. Section 5.2.1. discusses the head-marking plural system while section 5.2.2. discusses the modifying-plural system in some selected languages.

\footnotetext{
${ }^{44}$ This clarification is necessary to show that BNs can have a general number with the NumP projected in its nominal expression (the case of Ògè). In such structure, the claim is that the number feature is always present either PL or SG and since the noun is bare, the Num-head is not phonological filled (Num is always filled in languages in which the noun is inflected for number) the noun appears bare but with an inherent number feature which is pragmatically determined.
} 


\subsubsection{Head-marking plural languages}

This section discusses the phenomenon of plural marking in languages in which the plural marker instantiates a functional head. This section is further sub-divided into two. The target of the subsections is to discuss some terminologies which have been generally analyzed in the literature as features of head-marking plural languages: Agree, 5.2.1.1. and Pluralia tantum, 5.2.1.2. The main reason for the discussions of the terms is to show that these phenomena are not peculiar to head-marking languages alone and that they are in fact a universal feature of languages. For most of the discussions in this section, I will be using the terms 'inflectional' and 'head-marking' plural interchangeably. The reason is because they both refer to the same phenomenon in the sense that, the plural morpheme is argued to occupy the head of a functional projection and the plural morpheme is an inflection which is affixed to the pluralized noun. The languages that I discuss in this section are English (11-12), German (13) and the famous work of Ritter (1995) on the inflectional plural marking system in Hebrew (14). The assumption here is that in most cases, the singular form of the noun is distinct from the plural form and that the agreement of such forms with the verb is required.
(11) a. The child is coming
b. The children are coming English
(12) a. *the man chuckle
b. the men chuckle
(13) a. Das Kind kommt
DET child come
b. Die Kinder kommen
German
DET child come
'The child is coming.'
'The children are coming.'
c. *Das Kind kommen
DET child come
d. *Die Kinder kommt
DET child come


In English, the plural form of the noun child is 'children', in German, the plural form of Kind 'child' is Kinder 'children'. In both languages, the verb must agree with the noun, the ungrammaticality of (12a) shows that the plural form of the verb is not compatible with the singular form of the noun 'man' while in German, the singular form of the noun Kind 'child' is not compatible with the plural form of the verb kommen 'come' hence the ungrammaticality seen in $(13 \mathrm{c}, \mathrm{d})$.

In Hebrew, Ritter (1991) identifies two plural markers -im (Masculine) and -ot (Feminine). The examples in (14) show the occurrence of the plural suffixes in the context of periods of time.

(14) a. sa'a

'hour'

b. sa'ot

'hours'

c. sana

'year'

d. san-im

'years' (Ritter, 1995:409).

The plural affixes are inherently specified for number while nouns are inherently specified for gender. The gender affixes in Hebrew are the following: -it, -et or $-a$. Ritter argues that the gender affixes are derivational while the plural affixes are not, because the only interpretation of a noun with either of the two plural items can only be interpreted as plural. On the other hand, the interpretation of the noun with a feminine suffix to a masculine noun stem derives a distinct noun. 
(15) Masculine Nouns
a. amud - page
b. amud-im - pages

\section{Femine Nouns}

amud-a - column

amud-ot - columns

Ritter argues for a functional projection between the DET and the $\mathrm{N}$ which she calls number (Num), this head is the locus of number specifications (Singular and Plural) of the noun phrase. The NumP according to Ritter is headed by the inflectional affixes that are attached to the lexical stem in syntax because of head movement as represented in (16).

(16)

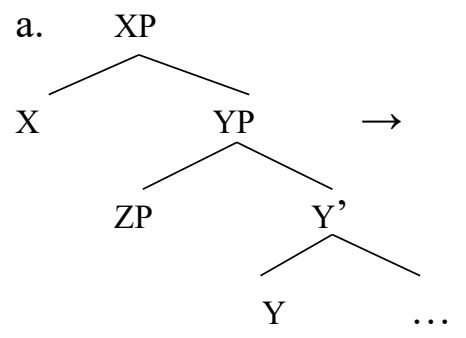

b.

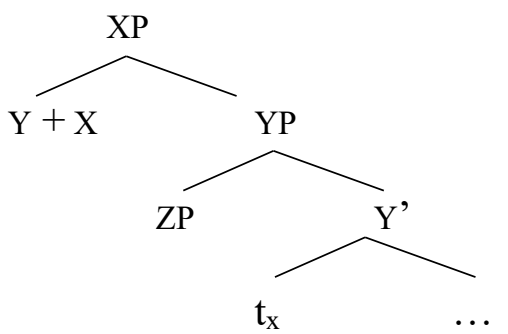

Here, the affixation of plural marking on nouns in Hebrew is likened to the affixation of tense and agreement on verbs - 'plural forms of nouns are derived in the syntax by the amalgamation of $\mathrm{N}$ and Num (Ritter 1991:53). Number marking is obligatory in this system because, the phonologically filled Num-head is obligatorily interpreted as plural while a singular noun phrase is represented by a null Num- head - this is interpreted as singular by default.

In summary, Ritter analyzes plural marker as a syntactic category, namely a functional head associated with number marking. In languages in which the plural morpheme has a morphological representation in the Num-head, it is argued that such languages have the property of pluralia tantum 5.2.1.2. and that Agree plays a vital role in plural marking 5.2.1.1. These properties (Pluralia tantum and Agree) however are argued not to be available in languages with the modifying plural feature (see section 5.2.2). As I argue in 
sections 5.3. and 5.4 for plural marking in Ògè, these peculiarities (meaning mismatches and Agree in number marking) are not restricted to certain languages, in fact they are a universal phenomenon.

\subsubsection{1. 'Agree' in head-marking plural languages}

In head-marking plural languages, 'Agree' is obligatory between the D-head and the Numhead because the unvalued Num-feature on $\mathrm{D}$ needs to be valued for number by the interpretable number features on Num. An example is given in (17) that shows that in English, the demonstratives and the determiners are inherently associated with number features that must be valued as either singular or plural depending on the number value of the following nominal. Consequently, the unvalued number feature on D must search for a matching number feature in its domain. Since it is assumed that the properties of a head are syntactically transparent if the merged item is of the same category as the head, the D-head can search and c-selects the matching number features on the Num-head.

(17) Match: [D D\#[\#\#:SG [N boy]]]

Value: [D D\#:SG [\#\#:SG [N boy]]]

Spell out: this boy

(Wiltschko 2008:652).

In the system shown above, it is obvious that the demonstrative is sensitive to number features and that the inserted demonstrative must bear the same number feature with the valued number feature on the D-head, PL - SG. The demonstrative is also an item in D just like the articles in English. ${ }^{45}$ As I showed earlier in chapter two, section 2.4., section 5.3.3. shows that the articles and the demonstratives can cooccur in Ògè. The

\footnotetext{
${ }^{45}$ Unlike the articles and the demonstratives in Ògè that can cooccur as I show in section 5.4., both elements cannot cooccur in English as the ungrammaticality of (i) shows:

(i) *the this dog
} 
demonstratives occupy the Dem-layer, while the articles occupy the D-head, the Dem-head is not sensitive to number features rather the elements in $\mathrm{D}$ are sensitive to number features (section 5.4.2.). In the example in (17), Agree happens between the D and the Num while the unvalued number feature on D is valued for SG and the output of Agree yields the spell out - 'this boy'. In this way, Agree is obligatory in head marking plural languages because the exponent associated with $\mathrm{D}_{[\mathrm{NUM}]}$ :SG must differ from that of $\mathrm{D}_{[\mathrm{NUM}]}: \mathrm{PL}$ this $\sim$ these. If match and value does not take place, the unvalued feature on $\mathrm{D}$ cannot be eliminated and the derivation crashes (Chomsky 2000, 2001). This means that the Num-head bears a bivalent number feature ( + or - plural). Invariably, in this system, not SG means PL, and not PL translates to SG, therefore a nominal with a plural form but with the semantics of a singular results in pluralia tantum in head-marking plural languages as discussed in the section immediately below.

\subsubsection{Pluralia tantum}

In the previous sections, we see that plural marking in head-marking languages instantiates a functional head which affects the label of the projection in which it occurs. The assumption is that form-meaning mismatches can arise if plural marking is a syntactic head. An example of such form-meaning mismatches is Pluralia tantum which refers to nouns which only exist in their plural forms, but which do not receive a plural interpretation i.e., 'pants' and 'scissors' in English. The assumption here is that if plural instantiates an obligatory syntactic head (as in English), it forces a semantic opposition: its absence implies a singular interpretation while its presence implies plural. The presence of the determiner obligatorily translates to the presence of the Num-head; Agree and c-selection must happen between the two heads otherwise the derivation crashes (Wiltschko 2008). 
Under this assumption regarding a bivalent number feature on the Num-head, the D must be valued for either SG or PL which means, if the D is not valued for plural, it needs to be valued for singular. This is quite different from the modifying plural languages as discussed in section 5.2.2. because, it is generally assumed that the absence of the plural morpheme does not imply singular rather, it means number neutral. In addition, unlike the head marking plural, plural marking in modifying-plural languages does not merge as a head rather, it merges as an adjunct which makes the layer it merges with opaque for selection. However, I posit that pluralia tantum is not peculiar to head-marking languages. It is possible to mis-interpret a plural referent as singular in some contexts in languages that are analyzed as modifying-plural-marking languages. As I show in section 5.2.2.4., the only difference is that the noun that receives a wrong number interpretation is bare. In the next section, I give some peculiar characteristics of plural marking in languages in which the plural word instantiates a layer other than the Num-head.

\subsubsection{Modifying-plural marking languages}

The previous sections discussed the system of plural marking in head-marking plural languages. We see that such languages possess a robust agreement and inflections which interact with number marking. In this section, we will see that languages with the modifying plural marking system do not have such robust agreement and inflections. Instead, nouns in modifying plural languages have a general form which gives no information regarding number (in this system, a BN could be interpreted as singular or plural). This section proceeds as follows: section 5.2.2.1. discusses the case of optional plural marking strategies as discussed in Wiltschko (2008) for Halkomelem, section 5.2.2.2. discusses Kim and Melchin (2018) for Korean and in section 5.2.2.3., I discuss Butler (2011) for Yucatec Maya. 


\subsubsection{Halkomelem (Wiltschko 2008)}

As mentioned earlier, some peculiar characteristics of the plural marker in this type of language is that the plural word does not occupy the Num-head, it is not obligatory in the nominal expression and it has a fixed interpretation which is 'plural'. Wiltschko (2008) identifies three main strategies of marking plurality on nouns in Halkomelem: reduplication (18b), infixation of $-l-(18 \mathrm{~d})$ and vowel change (18f). The BNs in (18a, c and e) are interpreted as either singular or plural.
(18) a. s-th'im
b. s-th'eth'im
c. q’ámi
d. q’álemi
NOM-berry
NOM-berry. PL
girl
girl. PL
'berry/berries'
'berries'
'girl/girls'
'girls'
e. swíweles
f. swóweles
boy
boy. PL
'boy/boys'
'boys'
(Wiltschko 2008:641) ${ }^{46}$

The unmarked form of the noun, swiweles 'boy' is compatible with the numeral 'three' just as the marked form is grammatical in this context as shown in (19a). In addition, number agreement within the nominal phrase is optional in Halkomelem; the plural form of the determiner ye is compatible with the singular form of the noun just as the singular form of the determiner te is grammatical with the plural form of the noun as shown in $(19 b, c)$.

a. te ihixw swiweles/swóweles

DET.SG three boy/boy.PL

'the three boys'

\footnotetext{
46 These sets of examples originally belong to Galloway (1980:14, 1993:379f.), in here, I modify the examples by providing an equivalent of the plural interpretation of the BN, since it is well-known that BNs in Halkomelem are ambiguous between a singular reading and plural reading.
} 


$\begin{array}{ll}\text { b. ye swíweles } & \text { c. te swóweles } \\ \text { DET.PL boy } & \text { DET.SG boy. PL } \\ \text { 'these boys' } & \text { 'these boys' }\end{array}$

Wiltschko argues that unlike plural markers in head-marking plural languages, plural marking in Halkomelem does not instantiate the functional head 'Num' but instead functions as a modifier (20). This suggests that Agree does not play a role in the appearance of the number morphology in Halkomelem because the properties of the plural marker are syntactically opaque and Agree can only happen between functional heads (i.e., the D and Num heads) whose properties are syntactically available for feature selection and feature valuation.

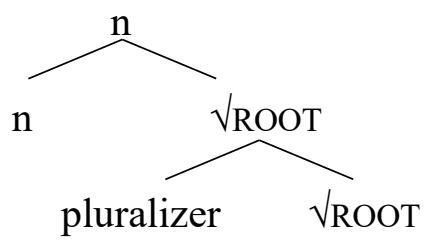

(Wiltschko 2008:680)

The pluralizers in Halkomelem modify roots and not nouns, therefore, the pluralizers are word internal modifiers that modify roots as shown in the examples in (21). Wiltschko argues that plural marking is possible inside of compounds, the example in (21a) shows that qo which is inside a compound word Tem-qo 'water time' is reduplicated to derive Tem-qoqo 'high-water-time'. In the same vein, wéxes 'frog' a word internal to a compound word is pluralized with lé which is an infix.

(21) a. Tem-qoqo qo

Time-water- PL water

'High water time' 
b. tem-weléxes wéxes

$$
\begin{aligned}
& \text { time-frog. PL frog } \\
& \text { 'time of frogs' = (March) }
\end{aligned}
$$

(Wiltschko 2008:664)

The examples in (21) support the argument that plural markings in Halkomelem are root modifiers which do not change the label of the category that they are attached to. Additional evidence for this is that the plural word is possible inside of the nominalizing prefix as shown in (22-23).

(22) a. s-xexp'-i:tsel

NOM-strip.PL-back

'chipmunk (with more than 2 stripes)'

b. xep

strip

'strip'

(23) a. s-qwelqwél-xel

NOM-hair.PL-leg

'tuft(s) on hair on a horses legs'

b. s-qwel

NOM-hair

'hair'

(Galloway 1980:63)

In the examples of plural marking given so far, we see that the plural marker in Halkomelem is structurally lower than the traditional NumP: the plural word can occur inside of a compound and it can occur inside of a nominalizing prefix. The characteristics of the plural word in Halkomelem show that the plural word is even lower than the categorizing heads that can occupy the $n$-head. Wiltschko makes a distinction between an inflectional and non-inflectional plural marking in languages by arguing that: 
What is traditionally analyzed as derivational occupies a categorizing head $(n, v$, or a) while what is traditionally analyzed as inflectional occupies a functional head (such as \#). Functional heads are higher than PL.

On the other hand, non-inflectional plural marking morphemes are closer to the roots and they are able to occur inside of categorizing heads.'

(Wiltschko 2008:675-676)

In the next section, I discuss -tul in Korean according to Kim \& Melchin (2018). The aim of the discussion is to show that -tul merges at a lower position where animacy is encoded unlike òtúro in Ògè that merges at a position where definiteness is encoded (see section 5.3.1.).

\subsubsection{Korean (Kim \& Melchin 2018)}

In this section, the focus is on the plural marker -tul in Korean as discussed in Kim \& Melchin (2018). -tul is like the plural markers already discussed in Halkomelem because of its optionality. BNs in Korean could be interpreted as either plural or singular (24) without an overt marking of plural.
(24) a. salam
b. sakwa
person apple
'a person or persons' 'an apple or apples'

(Kim \& Melchin 2018:9)

Kim \& Melchin (2018) argue that -tul shows idiosyncrasies based on its irregularity on some nouns, for example, -tul does not occur with animate (26c), therefore, they analyze $-t u l$ as a modifier of the $\mathrm{nP}$ and that it is left adjoined to the nP layer (25). The examples 
in (26) show that -tul can attach to almost any human noun (26a) and to many inanimate nouns (26b) but less frequently to animals (26c).

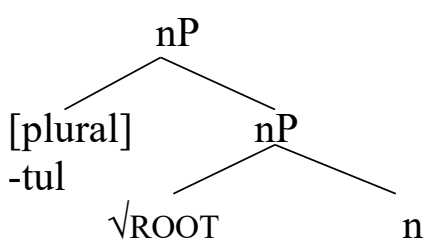

(26) a. Salam-tul sey myeng

Person- PL three cl

'three people'

b. chayk-tul sey kwun

book-PL three $\mathrm{cl}$

'three books'

c. ??kilin-tul sey mari

Giraffe-PL three cl

'three giraffes'

(Kim and Melchin 2018:13-14)

Based on the irregularity of $-t u l$ on non-human animate nouns (26c), the authors argue that there is no clear correlation between the animacy of a noun and the availability of pluralization with -tul. However, this idiosyncrasy is expected if -tul attaches to the $\mathrm{nP}$ layer, which is the locus of idiosyncrasy. In addition to the idiosyncratic features of -tul, Kim \& Melchin argue that -tul does not encode definiteness because a plural marked noun with -tul can receive an indefiniteness interpretation and as shown in (25), it is not in the D-layer because it is not connected to definiteness, this is further shown with the example in (27). 
(27) Mina-nun chayk-tul-ul uk-ci.an-ass-ta

Minna-TOP book-PL-ACC read-NEG-PST-DECL

'Minna didn’t read some books.' (i.e., 'There are some books that Minna didn't read'.)

(Kim and Melchin 2018:16)

\subsubsection{Yucatec Maya (Butler 2011)}

In sections 5.2.2.1. and 5.2.2.2., we see that the plural markers are not obligatorily present on nouns that denote plurality in both Halkomelem and Korean. For Halkomelem, Wiltschko argues for the adjunction of the plural word to the root because the plural word occurs below the categorizing head $n$. In Korean on the other hand, because of the irregularity of the presence of -tul on plural nouns, Kim and Melchin argue for the adjunction of -tul to the nP layer in the functional projection of the noun phrase. In Yucatec Maya (hence YM), the third person plural cross-reference marker $o$ 'ob is used as a plural number modifier of nouns (Butler 2011). ${ }^{47}$ Like Halkomelem, BNs in YM are number neutral: $x$-ch 'úupal 'girl/girls' in (26a) while the plural marked noun with $o$ 'ob is only interpreted as plural as shown in (28b).

(28) a. Taan u kàay le x-ch'úupal-o PROG A3 sing DEF FEM-girl-DIST

'The girl is singing'/The girls are singing.'

b. Táan u k'aayle x-ch'úupal-o'ob-o'

PROG A3 sing DEF FEM-girl-PL-DIST

'The girls are singing'

(Butler 2011:52)

\footnotetext{
${ }^{47}$ As shown in section 5.3., the overt realization of otúro translates to the obligatory interpretation of the noun as plural, in section 5.5. where I discussed pronouns in Ògè, Ótúro is not related to pronouns which makes it a distinct morpheme exclusively used for plural marking.
} 
Butler posits that in YM, unlike Halkomelem, the projection of the NumP may be necessary so as to serve as a landing site for the $\mathrm{N}$-movement in expressions in which the noun occurs in a pre-position to the second person plural pronoun e'ex as shown in (29), which is represented on the tree in $(29 b)$.

a. Kux túun a suku'un-e'ex-o'ob?

What.about then A2 elder.brother-B2PL-PL

'What about your (PL) elder brothers?'

b.

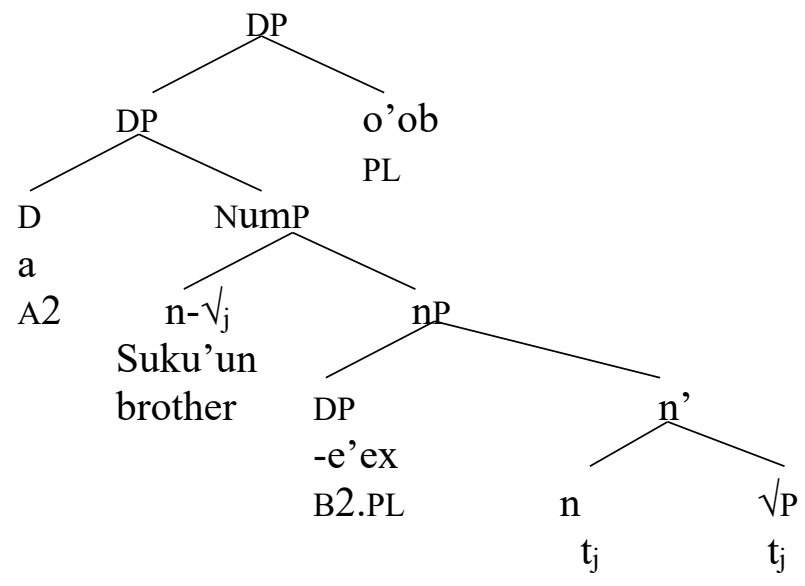

(Butler 2011:73)

Butler argues that the noun moves from its base position through the head position $n$ and finally to Num (successive cyclic head movement). The adjunction of $o$ 'ob at the D position supports the claim that agreement is not a feature of plural marking in YM because it is outside of the obligatory second person plural agreement suffix $-e$ 'ex which co-references the possessor. ${ }^{48}$ In addition to the evidence that there is no agreement involved in plural marking in YM, Butler provides the contexts in (30) to justify the

\footnotetext{
${ }^{48}$ Butler added that the first- and second-person plural agreement triggers obligatory agreement in the verbal domain, while the third person $-o$ 'ob does not.
} 
adjunction of the plural marker in the DP. He argues that plural marked DPs are interpreted as specific.

(30) Context 1: If a person goes to school wearing a new pair of shoes, people might ask him or her the question in (30a).

a. Tunben le xanab-o'?

new DEF shoe-DIST

'Are those shoes new?'

Context 2: If, however, a person goes to a shoe shop and sees one pair of shoes that look somewhat old on a rack with a bunch of other shoes that look shiny and new, they might ask the question in (30b).

b. Tumben le xanab-o'ob-o'?

New DEF shoe-PL-DIST

'Are those shoes new?'

(Butler 2011:75)

The plural marker in the context in 2 distinguishes a pair of shoes from the rest, put in another way, it picks out a pair among many shoes. It remains unclear though, how a plural marker can refer to a specific entity without being related to (in)definiteness. In (31b), Butler shows that when the plural marker occurs without the determiner, the reading of the noun is that of a generic or a kind interpretation.
a. le x-ch'uupal-o'ob
b. X-ch'ùupal-o'ob
DEF FEM-girl-PL
FEM-girl-PL
'the girls'
'girls'

(Butler 2011:55)

The occurrence of $o$ 'ob with le (definiteness marker in YM) shows that $o$ 'ob does not encode definiteness, this is further justified by the interpretation of the plural marked noun, $x$-ch'ùupal 'girl' with o'ob in (31b). The determiner le in the examples in (31) 
shows that the accompanied noun is marked for definiteness, but nothing shows when a noun is marked for indefiniteness. As is well known in the literature, a plural marker that is adjoined to the DP is sensitive to both (in)definiteness and specificity. Invariably, the noun phrase is either interpreted as being definite or indefinite/specific or non-specific or both when the plural marker is overt. This is true in Ògè as shown in section 5.3.1. on the interaction of otúro with definiteness and specificity interpretations of the nouns.

\section{3. Òtúro and the modifying plural morphemes (See section 5.2.2., for reference)}

This section compares otúro with the plural morphemes in modifying plural languages as discussed in section 5.2. As it will become clear in this section, otúro is the plural morpheme in Ògè, it is an independent marker of plurality just like àwọn in Yorùbá (Ajíbóyè 2005), o’ob in Yucatec Maya (Butler 2011) and ha in Igbo (Nweya 2016). The only difference between the mentioned plural morphemes and otúro is that the three plural morphemes mentioned are $3^{\text {rd }}$ person plural pronouns while òtúro is not a pronoun and it is not related to the pronouns in Ògè in any way (see section 5.5). Its sole function is to mark a noun for plural while àwon, $o$ 'ob and $h a$ are pronouns which also perform an additional marker of plurality. In section 5.3.1., I discuss other functions of òtúro in Ògè which are definite and specificity interpretations of the plural noun.

Unlike Halkomelem, plural marking is not possible on roots in Ògè. Òtúro does not occur inside of compounds (32b) and inside of the nominalizing prefix $i$ - (33). The ungrammatical examples in (32b and 33) is only grammatical if otúro applies to the noun and not to the root, this is shown in (34).

(32) a. uwan-uwan

child-child

'grandchild/grandchildren' 

b. *uwan-òtúro-uwan
child PL child

(33) a. *í -òtúro-yẹ̀n-yẹ̀n

NMLZ - PL - sweet - sweet
b. *í-òtúro-sin-sin
NMLZ - PL - black - black

(34) a. òtúro uwan-uwan

PL child-child

'the grandchildren'

*'the grandchild'

b. òtúro ísinsin

PL black

'the black ones'

*'the black one'

c. òtúro íyẹ̀nyẹ̀n

PL sweet

'the sweet ones'

'*the sweet one'

Furthermore, unlike -tul in Korean, òtúro is regular on all nouns, human (35a), nonhuman animate $(35 b)$, and on in-animate $(35 c)$.

(35) a. òtúro ẹ̀nẹ

PL person

'the people'

*'people' b. òtúro éswé

PL house

'the houses'

*'houses' c. òtúro ópú

PL dog

'the dogs'

*'dogs' 
As shown in the examples in (35), a plural noun with ottúro is interpreted as definite, this is not the case with -tul in Korean which does not allow the definiteness reading of the plural noun (see (27)). The next section (section 5.3.1) discusses the interactions of otúro with definiteness and specificity readings of the nouns, the aim of the section is to show that otúro unlike $o$ 'ob in YM is sensitive to both definiteness and specificity.

\subsubsection{The interaction of òtúro with definiteness in Ògè}

This section shows that a definiteness reading is available in the context in which oturo occurs. This section proposes that òtúro is related to definite interpretations of the noun. Otúro does not occur with the articles, ikárí/ikin (36a), (cf. the discussion of the elements in the DP of Ògè in chapter 2)

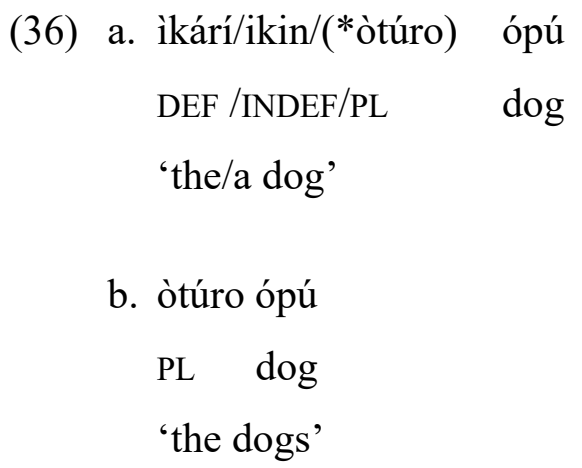

The significant aspect of this section is to establish the fact that otúro interacts with definiteness, when this happens, the interpretation of the expression could be definite, specific or definite, non-specific as shown in (37).

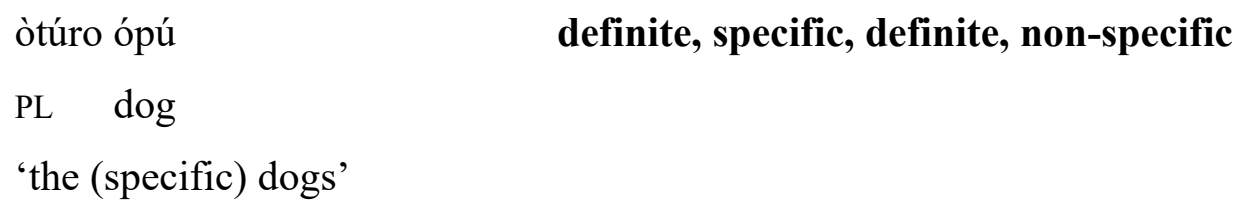


In (37), otúro interacts with both definite and specific reading of the noun. This is quite different from what we see in YM, in which the plural marker $o$ 'ob refers to only nouns that denotes genericity and kind reference, in such an analysis, the arguments that the plural marker adjoins to the DP layer is not a clear one. The claim that otúro interacts with both definiteness and specificity is like the analysis of the plural marker - $h a$ in Persian as reported in Ghomeshi (2003) because the plural marked noun with -ha receives a definite interpretation, this is illustrated with the example in (38b).

a. Un-a sæg-a-ye bozorg*(-i)-æ that-PL dog-PL-EZ big*-(-IND)-3PL

'Those are big dogs.'

(Ghomeshi 2003:48)

b. Bæčče-ha gerye=kærd-ænd child- PL cry $=$ do.PST-3PL 'The children cried.'

(Ghomeshi 2003:57)

In Persian, the co-occurrence of the plural marker and the indefinite enclitic is grammatical as shown in (38a) while in the absence of the indefinite enclitic and without the overt realization of the definite article, the pluralized noun is construed as definite. The example in (38a) shows that the plural marker does not encode definiteness but that plural marking yields a definite interpretation for a noun phrase when the indefinite enclitic is non-overt (38b). Òturo is like the marker of plurality -ha in Persian because a definite reading is construed when òtúro is overt (39i) but not an indefinite or generic interpretation (39iii.).

$$
\begin{aligned}
& \text { òtúro/òtúrin ópú } \\
& \mathrm{PL} / \mathrm{PL}+\mathrm{SPF} \operatorname{dog} \\
\text { i. = 'the dogs' } &
\end{aligned}
$$


ii. = 'some dogs in question'

iii. $=*$ some dogs'

However, unlike -ha òtúro is not grammatical in the context of the (in)definite article (40).

(40) ikin/ìkári (*òtúro) ópú

INDEF/DEF PL dog

This section has been on the (in)definiteness interpretation of oturro. I show that a BN is construed as either singular or plural noun. Most importantly, I show that otúro unlike $o$ 'ob for YM and -ha for Persian is sensitive to both definiteness and specificity. Bale et al (2011) posits that several things need to be considered in the process of the interpretation of number in languages: interpretation of a BN, interpretation of a plural noun and the interpretation of numerals (see section 5.4., for Ògè). They added that there is no mismatch between form and meaning in languages that have a plural only interpretation. In such languages, BNs are not interpreted as singular only. In section 5.3.3., I show that meaning mismatches could arise in the BN of languages in which plural nouns are interpreted as plural only. The question then arises as to why the meaning of plurality in the two systems could diverge based on the position of the occurrence of plural morphemes in the nominal projection of the noun phrase or based on the optionality of the plural morphemes? The next section discusses the parametric view of plural interpretations as seen in section 5.2. for head marking plural languages and the modifying plural marking languages in relation to òtúro. 


\subsubsection{Plural interpretations: a parametric view?}

In the three languages discussed (Halkomelem, Korean and YM), the plural marked nouns are obligatorily interpreted as plural while the plural morphology occupies different layers in the extended projection of the noun phrase. The parametric account of plural interpretations for modifying plural languages is shown in (41).

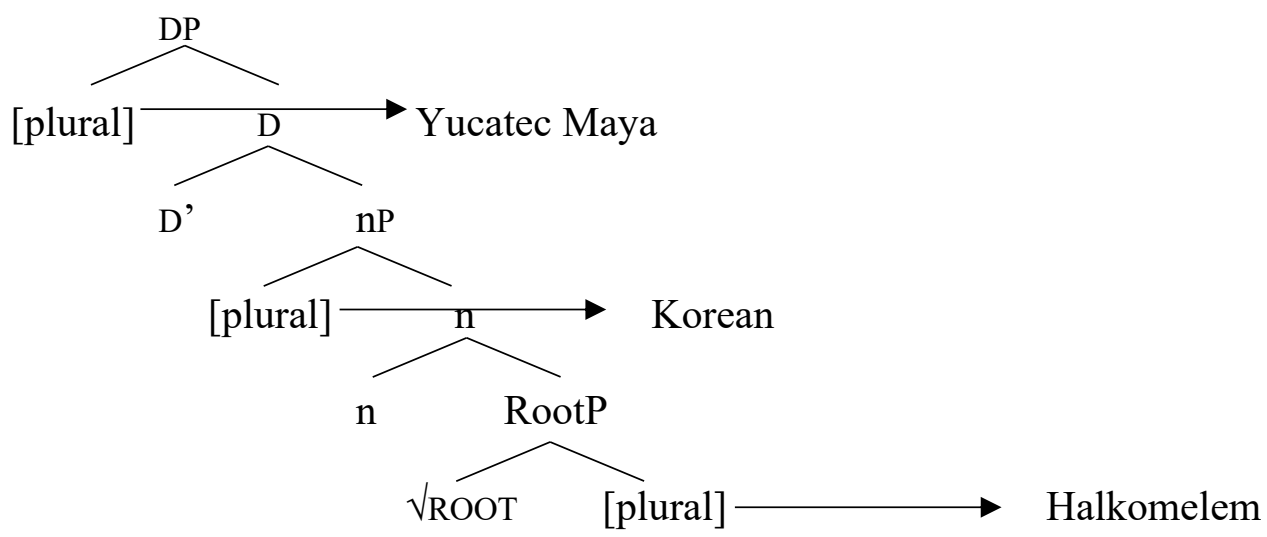

Parameter of plural marking in modifying-plural language

On the other hand, the plural morphology in head marking plural languages occupies a functional head position, 'the Num-head' A strong evidence in support of the position of occurrence of the plural inflection comes from agreement between the D-head and the Num-head. This conclusion then suggests that determining the readings of the plural available cross-linguistically depends largely on the different positions of the plural morphology within the functional projection of the noun phrase. The question then arises, as to what contributes to the difference in the number interpretations in the two systems? Can we conclude that the position of occurrence of number along the functional spine of the noun phrase is responsible for the different interpretations of the plural in the two systems? This question is largely answered in Alexiadou (2019). Alexiadou posits that plurality carries no inherent presuppositions and that its exclusive interpretation (in 
modifying plural languages) is a matter of pragmatics. She adds that plural in head marking plural languages is semantically unmarked and that therefore the plural is compatible with both singular (pluralia tantum, see section 5.2.) and plural interpretations. ${ }^{49}$ Similarly, a BN in modifying plural languages is semantically unmarked because it could be interpreted as either singular or plural (general number). She concludes that there is no semantic difference between the two systems of number marking (Head marking and Modifying plural marking) and that plural interpretation happens at the same position across languages. ${ }^{50}$ Going by the different views of the interpretation of plural discussed so far, the question then arises (i) does the plural in Ògè tally with the meaning associated with the plural in Head-marking languages or does it fall in line with the semantics of plural in the modifying plural languages? Is it right to go by the argument that indeed based on the parametric view of plural in languages, there is many a plural (the interpretation of plural in head-marking plural is different from the interpretation of plural in modifying plural languages: interpretation of plural comes from its position in the functional projection), (ii) What is its morpho-syntactic representation and does Agree play a role in the plural interpretations of nouns? (see section 5.2.1.1) (iii) what is the semantics of a BN in Ògè? In the next section, I start the discussion with the answer to the last question. The argument is based on the fact that despite the general number nature of BNs in Ògè, number (PL or SG) interpretations of the nouns are covert, they are only available when the elements in D are overt (see section 5.4.2. for the discussion of the vocabulary insertion in D).

\footnotetext{
${ }^{49}$ According to Alexiadou (2019), if the plural is semantically unmarked, this means that plural is compatible with singular reference and pragmatic blocking restricts its use while a semantically marked plural is never compatible with a singular reference.

${ }^{50}$ For Alexiadou, the plural morpheme is in Div $^{0}$ and it may be interpreted as inclusive across languages, therefore, she added that the interaction between number and semantic features such as animacy and definiteness contributes to the contexts of the uses of the plural morpheme.
} 


\subsubsection{General Number}

Nouns in Ògè unlike nouns in head-marking plural languages do not differentiate between a singular and a plural interpretation in all contexts. That is, the expression of number on nouns in Ògè is optional just like what we see in the languages with a modifying plural system (Halkomelem as seen in section 5.2.1., Yucatec Maya, as discussed in section 5.2.2. and Korean as discussed in section 5.2.3.). However, this section shows that despite the general number nature of BNs in Ògè, number marking on nouns is morphologically covert. In this sense, general number refers to languages in which the meaning of the noun can be expressed without reference to number. That is, a form of noun that disregards the distinction between singular and plural (Corbett 2000). The system of plural marking in the languages discussed in section 5.2.2. describes the concept of general number in clear terms: BNs in the three languages could mean one or more than one. However, the opposite is seen in section 5.2.1. in which languages in head-marking plural are forced to choose between singular and plural when they use a noun. The idea of general number adopted for nouns in this chapter follows the pattern in (42) in which Corbett (2000) shows that in languages with a general number, the forms of nouns do not specify the number of real-world entities involved. This means that the noun has a clear distinction between the singular and the plural form but at the same time, the noun can be used without a reference to number (general form).

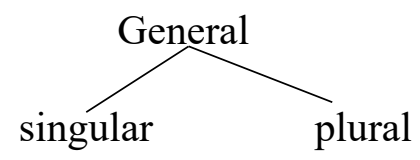

System with separate general number

(Corbett 2000:11) 
The nouns in the system in (42) have a general form and distinguish between singular and plural when required. The structure in (42) further shows that in the case of the nouns in Ògè, the form of the noun that is interpreted as one or two (general form) is the same as the form for the singular and the plural interpretations, but the difference in the plural and the singular interpretations come from the number interpretations of the article. This is further shown in the examples in (43). This three-way system as illustrated in (42), (adapted from Corbett (2000)) is shown in (43).

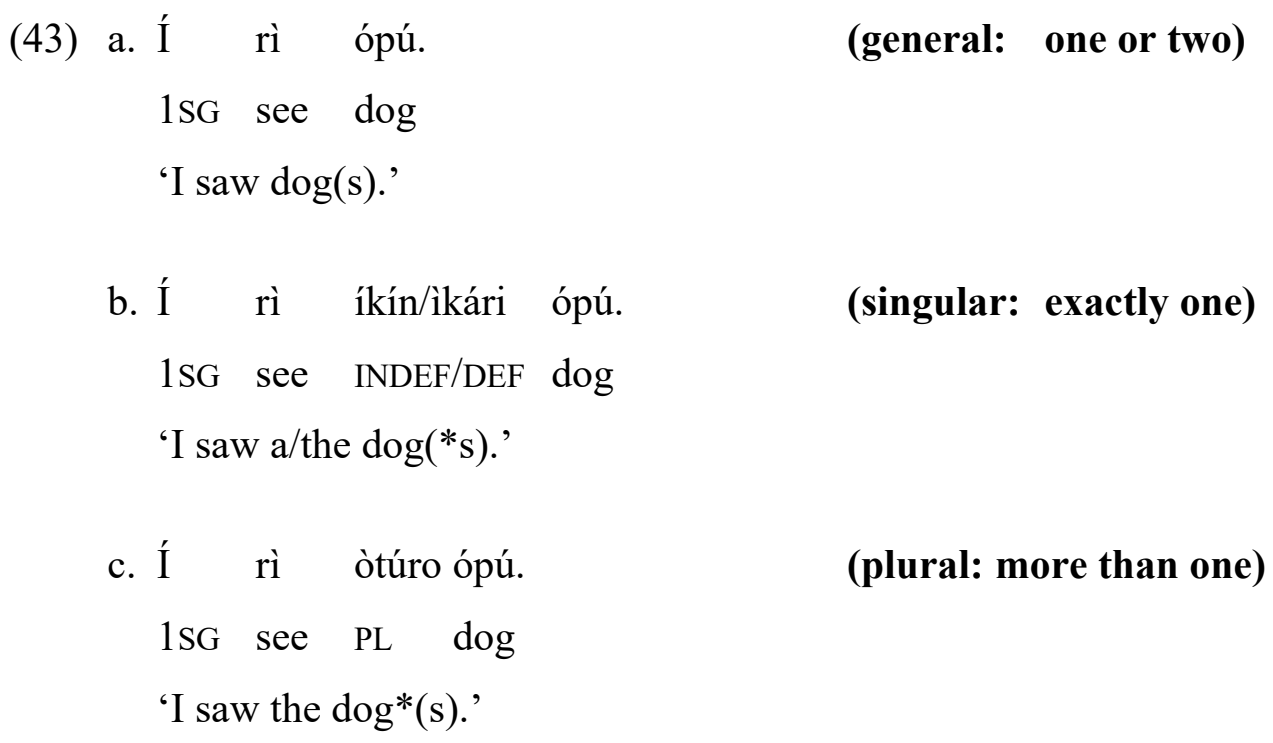

The noun ópú is general and refers to either plural or singular. However, òtúro is used to refer to plural while ikín 'a' or ikári 'the' are used in relevant contexts to refer to singular only. When otúro/ikin/ikári are not overt, then the noun phrase is not specified for number. Take for instance, in Yorùbá, a noun that is not specified for number can be interpreted in one of two ways; as singular (44a') or as plural (44a"). According to Ajíbóyè (2005), a count noun that occurs all by itself could be interpreted either as a singular or a plural noun (44a) and in the context in which it is modified by a nominal modifier (44b). 
(44) a. Moji rí ejò lọnà oko

M. see snakeon-path farm

a. ' Moji saw a snake on her way to farm.'

a." 'Moji saw snakes on her way to farm.'

b. Moji rí ejò dúdú lọ̀nà oko

M. see snakeblack on-path farm

b' 'Moji saw a black snake on her way to farm'

b' 'Moji saw black snakes on her way to farm.'

(Ajíbóyè 2005:222)

Ajíbóyè further shows that the noun ajá 'dog' in (45) can be interpreted as singular (interpretation of a BN as plural or singular is contextually determined).

(45) a. Context for singular interpretation:

I was walking on a path to my house at night and a dog appeared from nowhere. When I got home; I say (52b) to my wife.

b. Mo ri ajá lọ̀nà ilé

1SG see dog on-road house

'I saw a dog on my way home.'

As is evident in the examples given in this section, nouns in Yorùbá differ from languages in which the expression of plurality is inflectional. But on the contrary, I argue that it is possible for an unspecified noun for number to receive a plural interpretation when in fact the intended meaning is singular. Take for instance, the example in (45), nothing in the context, or the utterance blocks a plural interpretation. Based on this observation, I posit that it is possible to have a meaning mismatch in languages with modifying plural marking system. The only difference is that this case cannot be referred to as pluralia tantum or in a general term, form-meaning mismatches, because the noun in question is 
bare. Consider the BN ópú 'dog' in (46) for Ògè, the intended meaning is singular, however, it is possible for the hearer to mis-interpret the noun as plural.

(46) Í rì íge ópú úrùn áájá éswe
$1 \mathrm{SG}$ see $\mathrm{DEM} \operatorname{dog}$ on way home
'I saw that/those $\operatorname{dog}(\mathrm{s})$ on my way home.'

In other words, this chapter argues that despite the general number nature of nouns in Ògè, number is covertly specified on nouns and that context or the vocabulary items that accompany the noun contribute to the number interpretation of the noun. For example, ópú as used in (46) refers to a singular noun but nothing rules out a plural interpretation of ópú. The demonstrative igé 'that' is number neutral (this will become clear in section 5.4.3.). The noun ópú 'dog' as used here intuitively refers to a single 'dog', but because of the general number nature of a BN in Ògè, there is the possibility for ópu that I saw on my way home to be more than one. My proposals for plural marking in Ògè are the following;

(47) (i) The strategies of plural marking in Ògè are like the strategies of plural marking in modifying plural marking languages because of the optionality of òtúro.

(ii) The strategies of plural marking in Ògè differs from modifying plural marking languages because Ògè has a straightforward singular-plural system: the $\mathrm{D}$ in Ògè is number sensitive (see section 5.4.2.).

(iii) NumP is active in Ògè: the D elements are specified for number via Agree mechanisms on Num.

(iv) BN in Ògè have number specifications: the number specification is only seen once the D elements combine with BNs. 
Invariably this chapter shows that despite the general number nature of BNs in Ògè, NumP is projected in the syntax of Ògè. In Ògè, a language with optional number marking system, the BNs are covertly specified with number features, either PL or SG. This means that even though nouns in Ògè could be bare, this does not mean that plural marking in Ògè is modificational. Put in another way, supporting the assumptions in Alexiadou (2019), there is no such thing as many a plural. Number interpretations in languages come from the Num-head (see section 5.4). For Ògè, I propose that plurality does not only refer to plurality - additional meaning applies which are definiteness and specificity. This shows that number marking in Ògè does not diverge from either the head marking plural languages and the modifying plural marking languages on the basis of the optionality of òtúro, rather, this chapter argues that number marking in Ògè diverges because of other parameters: definiteness, specificity (see section 5.3.1)) and animacy (see section 5.6). ${ }^{51}$

\subsection{Number in Ògè: An analysis}

This section discusses number marking in Ògè. First, it identifies òtúro as the plural word. Second, it shows the various contexts of the occurrence of the plural word with nouns. As mentioned in sections 5.1.1. and 5.3., otúro is sensitive to the plural interpretations of the noun. Otúro is compatible with animate nouns both human (48a), animal (48a) and inanimate nouns (48c) and òtúro has a restricted distribution at the prenominal position, the ungrammaticality of the expressions in (49) shows this.

\footnotetext{
${ }^{51}$ This shows that in certain contexts in languages, plural and singular nouns have more restricted use because of the interactions between number and semantic features: animacy and definiteness, (Alexiadou 2019; Bale \& Khanjian 2014, for Western Armenian and Sag 2017, for Turkish).
} 
(48) a. òtúro ẹ̀nẹ

PL person

a.' 'the people'

a." 'some specific people'

a. '” *'the person'

b. òtúro ópú

PL dog

b. 'the dogs.'

b. ' 'some specific dogs'

b. ' * * 'the dog.'

c. òtúro àga.

PL chair

c.' 'the chairs.'

c. ' 'some specific chairs'

c. '” * * the chair.'

(49) a. *ẹ̀nẹ òtúro

person PL

b. *ópú òtúro

$\operatorname{dog}$ PL

c. *àga òtúro

chair PL

In some languages, plural marking is not required in the presence of the numerals. In such system, numerals strictly combine with BNs (Turkish, Aronoff and Fudeman (2011:6)). However, in English, the presence of a plural morphology is obligatory in the context of the numeral greater than one. ${ }^{52}$ In Ògè, numeral modifiers combine with BN (50a) and a

${ }^{52}$ An ungrammatical Turkish plural noun in the presence of a numeral is shown in (i). 
plural noun (50b), the interpretation of the noun has an additional reading when oturro is overt, which is a definite (specific) meaning.

(50) a. ìyí ópú.

two dog

a.' 'two dogs'

a." 'two non-specific dog*(s).

b. òtúro ìyí ópú.

PL two dog

b.' 'the two dogs'

b. ' 'The two $\operatorname{dog}^{*}(\mathrm{~s})$ in question.'

Apart from the compatibility of otúro with the numerals, the examples in (51) also show that otúro is compatible with a nominal modifier (51a) and a numeral plus nominal modifier (51b).

(51) a. òtúro íhòhòàga.

PL white chair

'the (specific) white chairs' b. òtúro ìyí íhòhòópú.

PL two whitedog

'the two white dogs'

However, òtúro does not occur with all items in a nominal expression in Ògè. For example, articles 'ikari/ikin' as shown in (36) repeated here in (52).

(i) iki fil $/ *$-er

twoelephant $/ *$-PL

'two elephants'

(Alexiadou 2019:3)

Alexiadou noted that there seems to be two types of languages - but the data from Ògè suggests that in fact, there is a third kind - which lies between the two identified languages - not English system and not the Turkish system - It seems the data in Ògè tallies with the data from Western Armenian as reported in Bale and Khanjian (2014) in that numerals can combine with both singular and plural count nouns as shown in (ii).

(ii) Yergu degha/degha-ner

Two boy/boys

The example in (ii) shows that the behavior of numerals with respect to number marking in languages is indeed dynamic (what remains to be known is how to come up with a proper classification for this third kind). In addition to the combination of the noun with the numeral as shown in (50), I follow the assumptions in Corbett $(2000: 211)$ that the plural marker is not required in a numeral $>$ noun string, the noun gets a plural reading in this context without the plural marker, see FN 8 for more on this. 

a. íkín/ìkári/(*òtúro) ópú
b. íkín/ikári/(*òtúro) àga INDEF/DEF/PL
$\operatorname{dog}$
INDEF/DEF/PL
chair

The examples in (52) are only grammatical when the (in)definite articles occur without otúro (53). In such contexts, the noun is obligatorily interpreted as singular.

$\begin{array}{lll}\text { (53) a. ikin/ikári ópú } & \text { b. } & \text { ikin/ikári àga } \\ \text { INDEF/DEF dog } & & \text { INDEF/DEF chair } \\ \text { a. ' 'a/the dog.' } & \text { b.' 'a/the chair' } \\ \text { a." *'the dogs' } & \text { b.' *'the chairs' }\end{array}$

The examples in (48-53) are crucial for my proposal in this chapter because of three important reasons: first, òtúro is a plural determiner, we know this because of the definite reading of the noun when òtúro is overt and the complementary distributions of ikári/ikin and otúro in (52) provides strong evidence that they occupy the same syntactic position. Second, òtúro is compatible with all categories of nouns, human-animate, animal-animate and inanimate nouns ${ }^{53}$. Third, ikári/ikin are sensitive to the singular interpretation of the noun. Summarizing the results of the discussions thus far, I have claimed that the articles in Ògè are sensitive to the number interpretations of the nouns: òtúro is sensitive to the plural interpretations of the nouns while ikári/ikin are sensitive to the singular interpretations of the nouns. We see that the articles are not obligatorily present in the nominal expressions of Ògè and when they do, they are preposed to the noun, (see also chapter 2 of this dissertation, section 2.2.). In the next section, what I explore is the syntactic analysis of how number interpretations come about using the mechanics of 'Agree' that I introduced earlier in section 5.1.2. In addition to this, I show the necessity

\footnotetext{
${ }^{53}$ This is quite different from a plural-word like -tul in Korean which is argued not to be regular on non-human animate nouns.
} 
of the projection of the NumP in the syntax of Ògè. We know that in languages with inflectional number marking, the Num-head is the layer for number inflection and that the Num-head is the host of the plural inflection, then the question arises as to why the NumP is projected in the syntax of Ògè since the Num-head is not phonologically filled.

\subsection{1. 'Agree' in number marking in Ògè}

Ritter (1991), (1995) argues that noun phrases can consist of at least three distinct layers: the DP which is the locus of definiteness, NumP, the locus of number marking, and NP, the lexical layer. For the structure of the DP in Ògè, I propose that the projection of the NP is dominated by the NumP and that the NP is the complement of the Num-head.

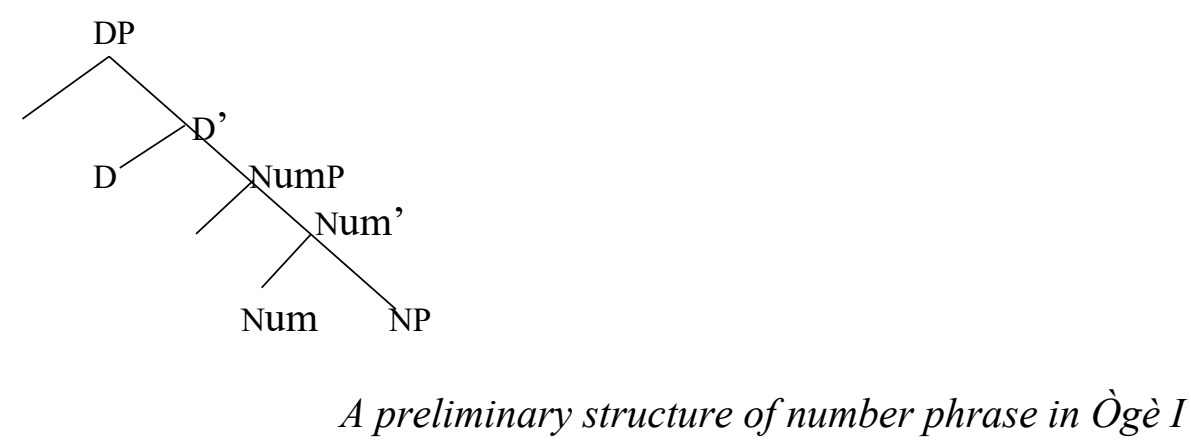

Earlier in section 5.1.2., I introduced the tenets of Agree according to Adger (2003; 2010) that I proposed for the analysis of number marking in Ògè. Basically, Agree happens between two nodes (D and the Num-heads) in syntax. The basic assumptions are that the $\mathrm{D}$ head is the probe which searches its domain for a matching feature that gives a value to its unvalued and uninterpretable number feature as shown earlier in (9) repeated here in (55). 
(55)

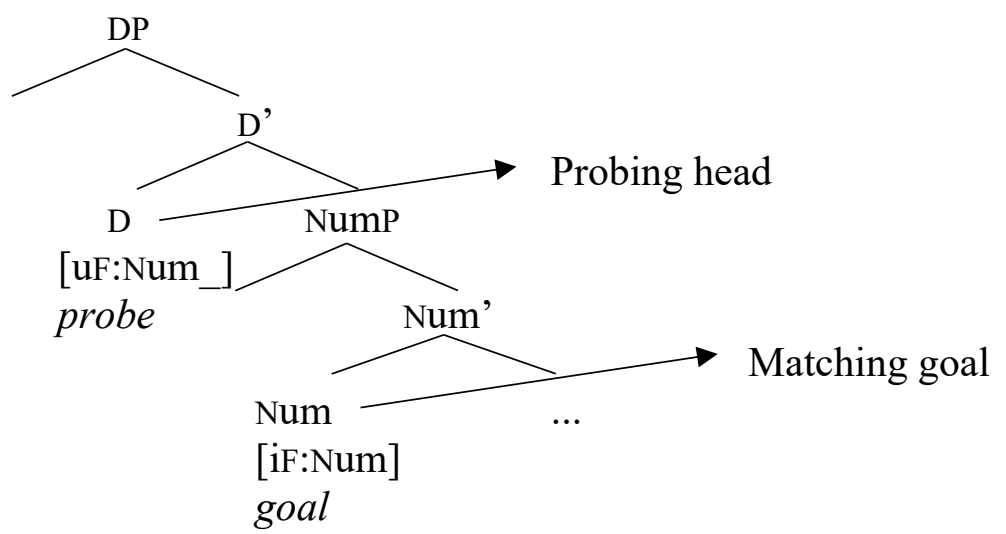

The claim is that Num enters the derivation with one of two number features: interpretable plural feature [iPL] (plural) or with an interpretable singular feature [iSG] (singular), since it is the locus of number interpretation. For Hebrew as discussed in section 5.2.1., we will recall that the Num-head hosts the plural morphology while in Halkomelem and other languages that were discussed in section 5.2.2. (Modifying plural languages), the NumP is not projected. However, in the theory developed here, we see why it is important to have the projection of the NumP in the derivation of number interpretations in Ògè even though it is not phonologically filled. We know that number in Ògè is not inflectional but a BN is specified for number features either singular ikári/ikín '(in)definite articles or a plural morphology otúro, this means that the number feature assumed on Num is active in the noun phrase of Ògè which is able to enter into a relationship with other features in syntax; number feature on Num is visible to the D-head for Agree and valuation - the unvalued number feature on $\mathrm{D}$ gets valued by whatever number feature that is present on the Num-head. For this work, I assume that the output of Agree and valuation yields a vocabulary insertion in $\mathrm{D}$ (see section 5.4.2.) immediately below. 


\subsubsection{Number sensitivity in $D$, an instance of 'Agree'}

Considering the examples in (48 through 53 above), I claim that the number interpretations of the noun phrase in Ògè in the presence of ikári, ikín, òtúro is derived by assuming an interpretable number feature on the Num-head. The vocabulary insertion of the relevant number morphology in $\mathrm{D}$ is derived through the feature checking configurations between the D and the Num-head. As a starting point, following the assumptions in the distributed morphology as laid out in Halle and Marantz (1993) I propose that an item like ópú 'dog' needs to combine with a nominalizing head $n$ to form the noun ópu $-\operatorname{dog}$. In this system, $n$ is the category defining node which gives a category to ópú to form $\mathrm{nP}$, this is represented in the structure in (56).

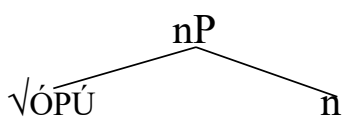

Recall that the proposed structure for number phrase in Ògè as given in (54) shows that the $\mathrm{nP}$ is dominated by the projection of the NumP, the structure in (57) is obligatorily interpreted as plural.

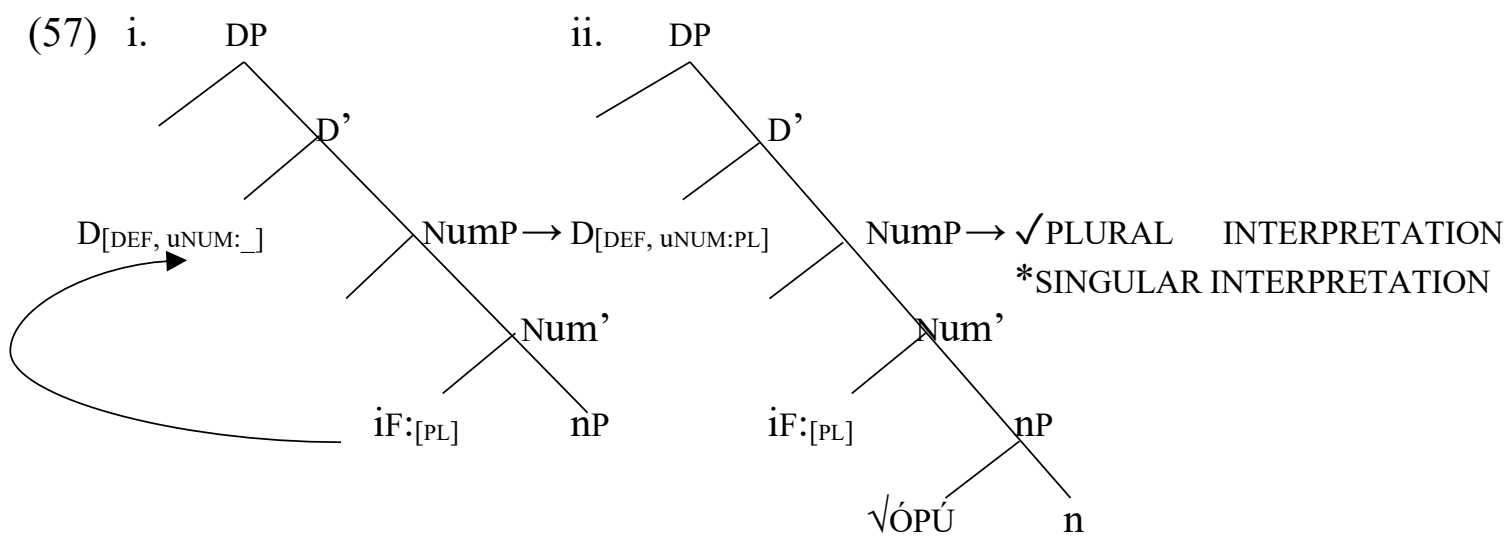

The structure in (57) is a typical Agree configuration in which the feature on the goal is copied or shared across syntactic structures by Agree. The relationship between the D- 
head and the Num-head is that of a c-command relationship. The D-head (probe) gets its number value from the Num-head (goal). In the course of the derivation, the interpretable plural feature on the Num-head gives its value to the uninterpretable number feature on the D-head (57-ii). The output of the Agree pattern seen in (57), specifically D[DEF, unUm:PL], is the vocabulary insertion of a matching number feature in D as represented in (58). ${ }^{54}$ $\mathrm{D}_{[\mathrm{DEF}, \mathrm{uNUM}: \mathrm{PL}]} \quad=\quad /$ òtúro/

On the other hand, the examples in (53), repeated here in (59), show that when ikárilikin is overt, the interpretation of the noun phrase is obligatorily singular.
ikári ópú
DEF $\operatorname{dog}$
b. ikín ópú
INDEF $\operatorname{dog}$
a.' 'the dog'
a.' * * the dogs'
b.' 'a dog'
b. " *'dogs'

In such contexts, the number feature specification on the Num-head is [iSG], this is schematized in (60).

\footnotetext{
${ }^{54}$ It is important to note that the system advocated here is different from the feature percolation mechanisms of Ajíbóyè's (2010), proposal for the plural morpheme àwọn in Yorùbá. Ajíbóyè (2010), proposed a feature theory which is aimed at how nouns that are not morphologically marked for plural receive a plural interpretation. The assumption is that plural feature percolation mechanism copies the plural feature of a node onto the node that immediately dominates it. The plural morpheme is assumed to have an abstract [PLURAL] feature, which can be realized on nouns or non-nouns that they co-occur with through a feature percolation mechanism (Ajíbóyè 2010:228). While Ajíbóyè's system define a consistent way through which the NP in Yorùbá could receive a plural interpretation-it is not clear how a syntactic feature is permitted to percolate from an adjunct to the head in a phrase. He also notes this problem when he comments that 'what makes an NP plural does not essentially rely on the head per se' (Ajíbóyè, 2005:146). He however added that a plural feature of an adjunct can percolate onto the NP if the head that the adjunct is adjoined to is not specified for plural. While the plural morpheme in Yorùbá is analyzed as an adjunct which bears a plural feature, the plural feature in the system advocated in the present dissertation is situated on the Num-head following the laid down assumptions in Ritter $(1991,1995)$ for number marking in languages.
} 


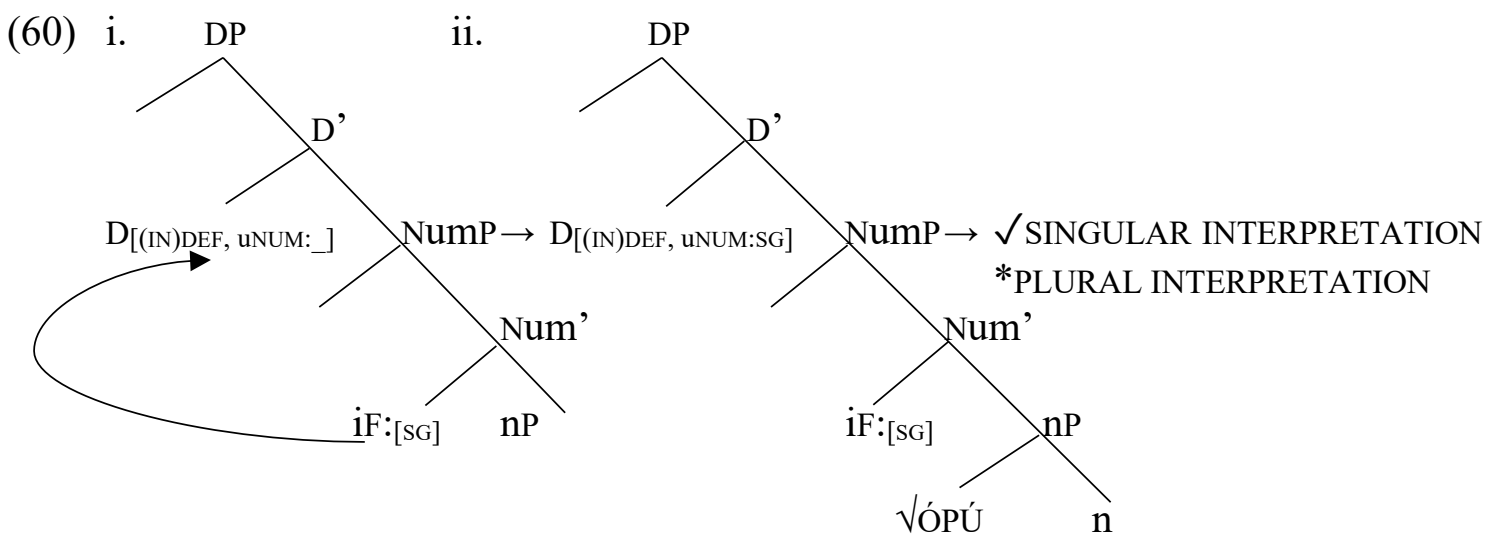

The feature checking configurations in (60) results to the vocabulary insertion of ikári/íkín in D.

(61) a. [DDEF, UNum:SG] $\leftrightarrow$ /ikári/

b. [DINDEF, UNum:SG] $\leftrightarrow$ /íkín/

Recall that in section 5.1.2., the claim was that the Num-head values the uninterpretable number feature in D. The valued number feature [uNum:SG] on D in (60) is obligatorily spelt out as ikári or ikin 'the/a' depending on the (in)definiteness feature associated with the noun. In this system, D is sensitive to number interpretations based on the different items inserted in D in relation to the valued number features in D. The next section further supports the analysis in this section on the number sensitivity of the D position by showing that demonstratives in Ògè are indifferent when it comes to the interpretation of number in Ògè.

\subsubsection{Demonstratives}

Section 5.4.1. has shown that number interpretations are associated with the number feature specifications on the Num-heads in relation to the overt realization of the elements in D. We observe that when the number specifications feature is plural, òturo gets inserted 
into the D-head, the overt realization of otúro translates to the plural interpretation of the noun and it cannot be interpreted otherwise. ${ }^{55}$ This section shows two things about number marking in Ògè in relation to the demonstratives (i) number morphology is located higher than the DemP layer (ii) demonstratives are not number sensitive as opposed to the determiners in Ògè. The ungrammaticality of (63) shows that otúro is restricted to the pre-position of the demonstratives.

(62) a. òtúro ígé ópú

$$
\text { PL DEM dog }
$$

a.' 'those dogs'

a." *'that dog'

(63)

$$
\begin{aligned}
& \text { *ígé òtúro ópú } \\
& \text { DEM PL dog }
\end{aligned}
$$

b. òtúro íghẹ́ ópú

PL DEM dog

b.' 'these dogs'

b. " *'this dog'

b. *íghẹe òtúro ópú

DEM PL dog

Further, the demonstratives in Ògè can cooccur with the (in)definite articles (64a), when this happens, the demonstrative is not acceptable at the pre-position of the article (64b), the noun is obligatorily interpreted as singular and otúro does not cooccur with the two elements (demonstratives and (in)definite articles) (64c). The essence of this discussion is to further support the claim that ikári/ikín and otúro do not cooccur in a noun phrase.
(64) a. ikári ígé ópú
DEF DEM dog
b. *ígé ìkári ópú
DEM DEF dog
c. *òtúro ikári ígé ópú
PL DEF DEMdog
a.' 'that dog'
a." *'those dogs'

\footnotetext{
${ }^{55}$ The plural interpretation of the noun as described and analyzed here could only have a monovalent plural feature, a vocabulary insertion of òtúro in D could only be interpreted as definite plural. Invariably, in Ògè, the overt realization of otúro translates to strict plural noun (no such things like jeans or pants that blur the lines between a singular and plural interpretations in English).
} 
In addition to the evidence in support of the position of occurrence of oturro (highest position in the DP), I further show that in the presence of the demonstrative, the numeral and the nominal modifier, ótúro is only acceptable at the initial position of the noun phrase, this is illustrated with the examples in (65a).

a. òtúro ígé ìyí íhòhò áchọ́ PL DEM two white cloth 'those two white cloths' b. *ígé òtúro ìyí íhòhò áchọ DEM PL two white cloth c. * ìyí òtúro ígé íhòhò áchọ́ two PL DEM white cloth d. * íhòhò òtúro ígé ìyí áchọ white PL DEM two cloth

Based on the cooccurrence of the demonstrative and ikári/ikin on the one hand and on the occurrence of the demonstrative with otúro on the other hand, a modified version of the preliminary structure of the number phrase in Ògè that was presented in (54) is given in (66).

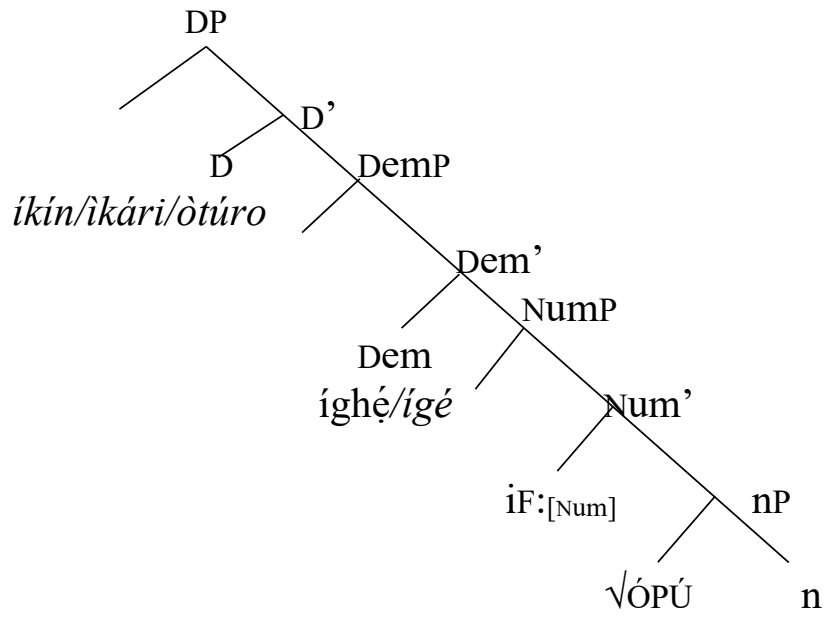

A preliminary structure of number phrase in Ògè II (see section 5.4.5., for the updated version) 
The D-head is associated with the determiners while the Dem-head hosts the demonstratives. The structure in (66) is further supported by the strict order DEF $>$ DEM that we see in the linear order of the two elements (64), this shows that the Dem is beneath the D layer. The structure in (66) follows the basic assumption in the literature that Num could be dominated by the projection of Dem, but in the data that we have seen so far, otúro appears to the left of Dem which further supports the analysis of òtúro as an element not situated in Num

The second point that this section sets to make is that unlike the determiners in Ògè, the demonstratives are not number sensitive, this means that when the Dem-head is occupied by one of the demonstratives (igé/ighẹ), the number interpretation of the noun is similar to the interpretation of the noun with a null D; the noun is interpreted based on the interpretable number feature on the Num-head, (either singular/plural). This is further expatiated with the examples in (67 and 68).
a. ígé ópú DEM dog
b. òtúro ígé ópú PL DEM dog
c. ìkári/íkín ígé ópú (IN)DEF DEM dog
a.' 'those dogs'
b.' 'those dogs'
c. ' *'those dogs'
a." 'that dog'
b. " *'that dog'
c." 'that dog'

(68) a. íghẹ ópú DEM dog
a. ' this dog'
a." 'these dogs'

b. òtúro íghẹ́ ópú PL DEM dog

b. * *'this dog'

b." 'these dogs' c. ikári/íkín íghẹ ópú (IN)DEF DEM dog

c.' 'this dog'

c." *'these dogs'

The examples in (67a) and (68a) get number interpretations either singular (67a',68a') or plural $\left(67 \mathrm{a}^{\prime \prime}\right.$ and $\left.68 \mathrm{a}^{\prime \prime}\right)$ based on the interpretable number feature on Num, in such expressions, the D-head is not phonologically filled, hence there is no item that is sensitive 
to the number interpretations in D. In the $b$ and $c$ examples in which the item in $\mathrm{D}$ is the output of feature checking and feature valuation between the D and the Num, and the interpretable number feature on Num, the noun is interpreted either as definite plural or as singular noun.

\subsubsection{BNs in Ògè: a case of general number?}

This section is a follow up on the general number nature of BNs in Ògè that was discussed in section 5.3.3. in which the general number nature of the nouns shows that a BN in Ògè could mean one or more than one and that the number interpretations of a $\mathrm{BN}$ depend on the context of usage. I repeat the example in (46) here in (69) to show the meaning mismatches of a BN in Ògè.

(69) Í rì ígé ópú úrùn áájá éswe

$1 \mathrm{SG}$ see DEM dog on way home

'I saw that/those $\operatorname{dog}(\mathrm{s})$ on my way home.'

The BN ópú could mean one or more than one in (69), therefore, the aim of this section is to further support the proposed structures for the noun phrase in Ògè as presented in (54) and in (66). The NumP is projected in the noun phrase of Ògè and it is the locus of number interpretations. Basically, this section shows that the BN in Ògè gets it number interpretations from the Num-head. In (70), just like ópú in (69), ópú could be interpreted as either singular or plural depending on the interpretable number specifications on the Num-head. 
(70) a. Í rì ópú

$1 \mathrm{SG}$ see dog

a.' 'I saw a/the dog.'

a." 'I saw some unspecified dogs.'

a. "' *'I saw the dogs.'

b. Ópú si úrún éswe dog COP PP house

b.' 'A/The dog is in the house.'

b. ' 'Some unspecified dogs are in the house.'

b. '”*'The dogs are in the house.'

In such contexts of the utterance in (69) and (70), it is common for the hearer to ask a clarifying question to know if the referent is one or are more than one. Questions like 'How many dogs did you see?' or 'was it one dog that you saw?' could be asked while one could ask questions like 'How many dogs are in the room?' or 'I hope it is only one dog that you saw in the room' regarding the example in (70a). The questions could take any form just to clarify if the noun referred to is one or are more than one. In the configurations in (71), the D head is null and since there is only one interpretable number feature in Num, the Num will only be able to license one interpretable number feature in a configuration at a time. No designated number feature is specified on the structure in (71), which means, if the feature on Num is singular, then it will license a singular interpretation of the noun. On the other hand, if the number feature on Num is plural, a plural interpretation of the noun will be licensed. This discrepancy is expected on Num since there is no morphological element that is sensitive for number features in D or in the layer beneath D. 


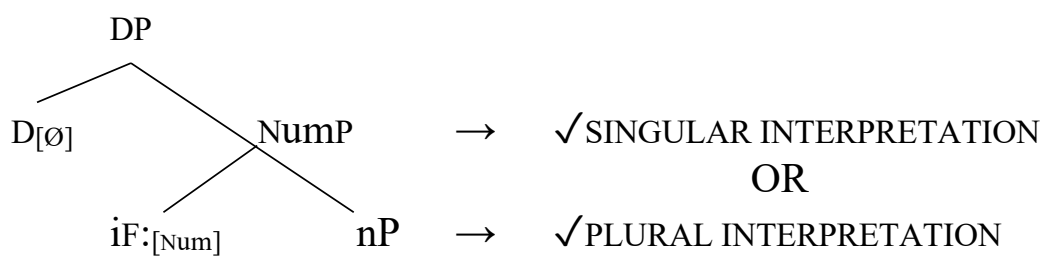

The only element which morphologically shows number alternations is D. Thus, in the absence of D elements, all nouns will look bare, leading to the general number nature of BNs in Ògè.

In addition, on the surface, as explained above, one could conclude that a BN in Ògè is underdetermined for number (it could be interpreted either way) but based on the evidence as laid out in section 5.3.1. we see that this is not the case for BNs in Ògè. BNs in Ògè have number specifications: but it is only seen once the D-elements combine with them, this is seen in the structure in (71) above.

\subsubsection{The quantifiers, ìgào, ikúwọ́ and òtúro}

This section discusses two main quantifiers that are frequently used in the syntax of Ògè: igào 'all' and ikúwọ 'some'. In addition to the interpretation of ìgào as 'all', it could also be interpreted as 'every'. The interpretation of 'every' with igào translates to a collective reading and not a division reading that one could get in constructions like "he jumped over every pole'. This section shows instead that igào is used in a context where 'all' would be used and that it is difficult to assign a one to one English interpretation to it. The quantifiers in Ògè just like in many other languages are inherently plural. This explains why the cooccurrence of the quantifiers and otúro is grammatical as shown in $(72 a, b)$, in (72c), the quantifiers in Ògè do not cooccur with the (in)definite articles which show that the quantifiers in Ògè select for a plural structure (plural D) and not just any Dheaded complement. 
(72) a. ìgào òtúro ópú

all PL dog

a.' 'all dogs'

a." 'all the specific dogs'

b. ikúwọ́ òtúro isi

some PL yam

b.' 'some yams'

b. ' 'some specific yams'

c. *ìgào ìkári ópú

all DEF dog

The ungrammaticality of the expressions in (73) show that oturo has a restricted distribution to the post-position of the quantifier and that it does not occupy the highest position in the nominal spine of Ògè.
a. * òtúro ìgào ópú
b. *òtúro ikúwọ́ ìsi
PL all dog
PL some yam

In addition, the quantifier can cooccur with the demonstrative (74b). When this happens, the demonstrative gets a plural reading (74b') while a singular reading of the demonstrative is not possible (74b“)
(74) a. ìgào ópú
b. ìgào ígé ópú
all dog
all DEM dog
a.' 'all the dogs'
b.' 'all those dogs'
a." 'all dogs'
b. " *aall that dog'

The examples in (74) further tell us two things about the quantifiers in Ògè: first, they do not require otúro to be plural. Second, the Quant-head takes the D-head as its complement. 
The modified version of the preliminary structure of count nouns in Ògè (final version) is given in (75) while the feature checking configuration between the D-head and the Numhead is shown in (76).

(75)

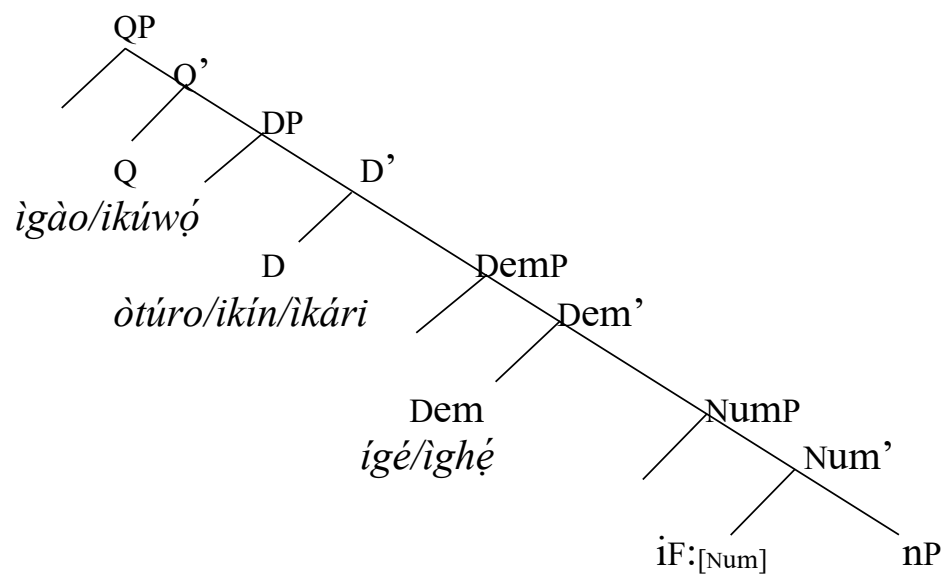

The Structure of a count number phrase in Ògè (final version)

(76) a.

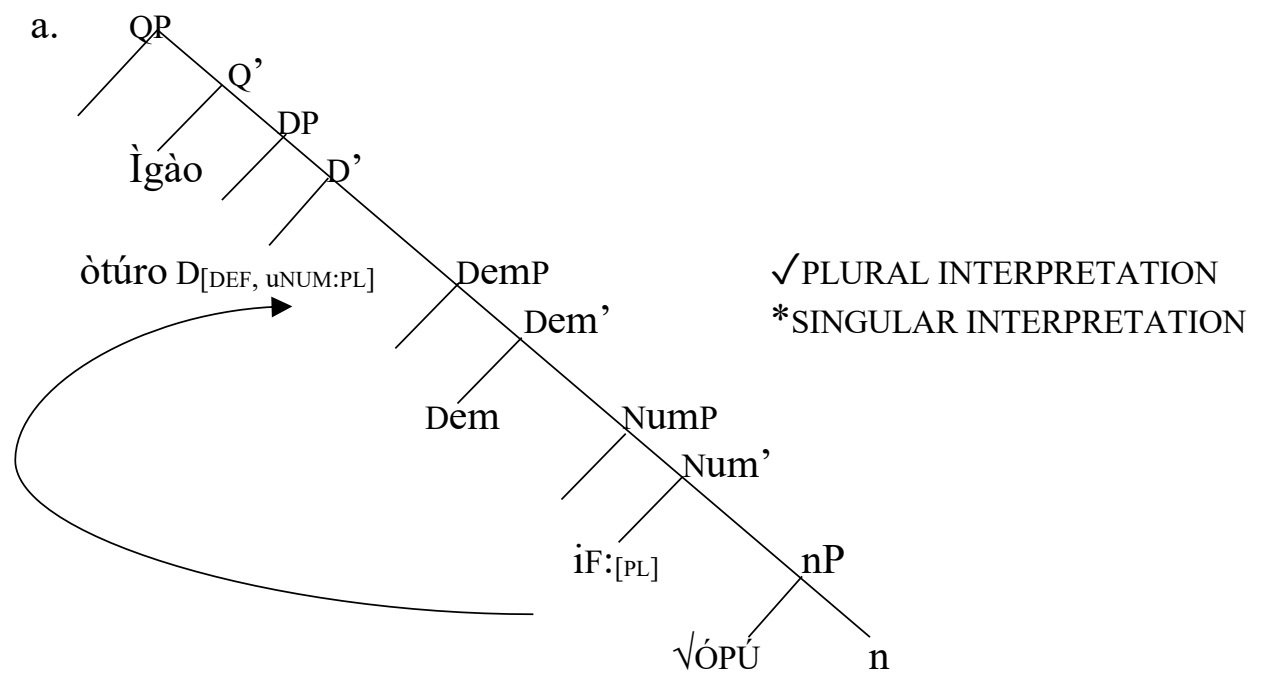


b

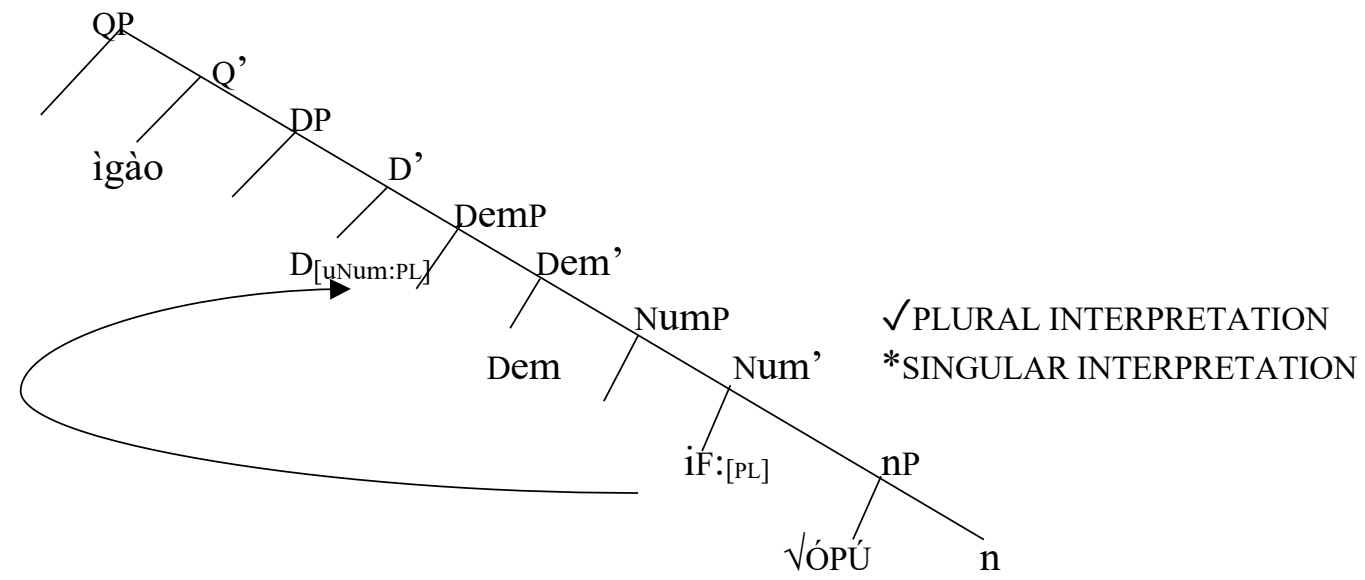

As seen earlier in (71), the Num-head is [SG] in some null D but [PL] in other null D - this accounts for why (76b) cannot have a singular reading because only the [PL] version of the $\mathrm{D}$ is compatible with the quantifier as seen by the unacceptable string in (72c) but shown by the acceptable expression in $(72 a, b)$.

\subsubsection{Interim summary}

I have looked at the number interpretations of count noun phrases in different contexts: overt realization of the articles, optional marker of plural and when all items are covert. The main claim of this section is that $\mathrm{D}$ gets its number value from the Num-head through the mechanism of Agree and the element in D inherits its feature value either SG or PL. This is laid out clearly in (77).
a. D [DEF, unUM:PL] $\leftrightarrow$ /òtúro/
b. D [DEF, uNUM:SG] $\leftrightarrow$ /ikári/
c. D [INDEF, unUM:SG] $\leftrightarrow \quad$ /íkín/

The proposal that the D-head gets its number feature specifications from the Num-head has two implications: first, the vocabulary item in D is inserted as a result of the feature checking configurations between the D and the Num-head. Second, the uninterpretable number feature on the Num-head are spelled out as null $[\varnothing]$ on $\mathrm{D}$, which has the effect 
that a BN results (unless the D is plural definite). The NumP is active in the number specifications of nouns in Ògè because the D-head (probe) derives its number specifications from the Num-head (goal) through an agreement process. This is an apparent selectional relation between the D and the Num-heads.

The proposal of an (un)interpretable number feature for number marking in Ògè makes it easy for the language learner to acquire the system of number marking in the language. Take for instance, when a learner acquires the feature specifications for a given Num [iPL/iSG], this is the only feature specification that is encoded in the learner's linguistic knowledge in terms of (i) an interpretable plural feature [iPL] is associated with òtúro, or (ii) an interpretable singular feature [iSG] is associated with ikári, and ikin. The absence/non-occurrence of otúro is partition into two: (iia) overt realization of the article is associated with singular [SG] and (iib) is when the D is null (a BN), the learner uses discourse context to choose between a plural and a singular feature (here, the number feature specifications on the Num-head plays a role), (adapted from Svenonius 2017:11). Having discussed and analyzed the number interpretation of count nouns in section 5.4., the next section discusses the number interpretation of mass nouns in Ògè.

\section{5. Ògè mass nouns are not compatible with Òtúro}

In the previous sections, we will recall that otúro pluralizes count nouns and that it is a plural determiner. We know that the compatibility of the plural morphology with mass nouns could be language specific and that there are interesting theories that are developed to account for the behavior of the plural morphology with regards to the mass/count distinction (Ghomeshi 2003; Borer 2005; Acquaviva 2008). This section discusses the status of mass nouns in Ògè with respect to the inability of the occurrence with òturo 
even in the context of the numeral. In section 5.5.1., it is acceptable for a count noun to occur with otúro and the numeral as shown in (50 and 51), repeated here in (78).
(78) a. òtúro ìyí ópú.
b. òtúro ìyí íhòhòópú.
PL two dog
PL two white dog
a.' 'the two dogs'
'the two white dogs'
a." 'The two $\operatorname{dog} *(s)$ in question.'

In this section, we will see that the numeral is compatible with a mass noun only if it is followed by a measure word like igò 'bottle', garawa 'bucket' etc., (see example in (80)). Otúro is not acceptable with the numeral in the context of the mass noun (the numeral is not enough in this context with a mass noun without a measure word). In addition, I show that temporal phrases behave like mass nouns in the sense that, otúro does not mark plural on them (see section 5.5.2.). However, in some contexts, otúro is used to mark definite (specific) on a temporal phrase. This section concludes that, in such contexts, otúro is a marker of definite specific and not a plural definite.

\subsubsection{Mass nouns in Ògè}

This section discusses mass nouns in Ògè in relation to number marking. First, I show that otúro is not compatible with a mass noun, Second, I argue that the numeral is only acceptable with the mass nouns if there is a common background knowledge in the discussion (there are exceptions to this claim (see, (80c)). Third, ikári, and ikín are acceptable with the mass noun but not for number purposes and fourth, the quantifiers in Ògè are compatible with mass nouns.

In some languages, it is a common knowledge that the combination of the plural marker with the mass noun results in an abundance reading, e.g., Greek, (Tsoulas 2007), 
Persian, (Ghomeshi 2003). ${ }^{56}$ However, Ògè does not allow òtúro to combine with mass nouns. $^{57}$

(79) a. *òtúro ùji kẹerẹnúrẹe

PL water drop roof

INTENDED: dripping waters from the roof'

b. *òtúro ùji úrùn oòsírí

PL water PP compound

INTENDED: 'The compound is full of water'

For the example in (79a), the intended meaning would be that the drop of water is more than one. In this case, it is not grammatical to combine òtúro directly with ùji 'water' to form a plural reading (a lot of water). In the example in (79b), the intended meaning would be a reading of abundance, the ungrammaticality of this expression shows that òtúro does not have an abundance reading.

In addition, as pointed out in (50) and repeated here in (80), numerals are compatible with count nouns but not with mass nouns in an out of the blue context, as shown by the unacceptable example in (80a). The example in (80c) is only acceptable if there is a common background knowledge in the discussion such that the hearer is aware of a

\footnotetext{
${ }^{56}$ Halkomelem is an example of a language which does not show a mass/count distinction by allowing the plural morphology to occur both on mass and count nouns. (Wiltschko 2008).

(i) Tsel kw’éts-l-exw te/ye syiqyíq

1SG.S see-TRANS-3ODET/DET.PL ice.PL

'I've seen a lot of snow.' (Wiltschko 2008:669)

${ }^{57}$ A typical example of a mass/count distinction language is Telugu (Smith 2015). Telugu does not allow mass nouns to combine with the plural suffix -lu (iia), while count nouns combine freely with - $l u$ in order to form plural (iib).

(ii) a. $\quad$ *aa abbaji isuka-lu tavvu-tunn-aa-Du

Theboy sand-PLdig-PROG-PRES-3.NON MASC.SG

INTENDED: 'The boy is digging sands.'

b. Kukka-lu tinn-aa-ji

Dog-PL eat-PAST-3.NM.PL

'Dogs ate.'

(Smith 2015:44)
} 
measure word like igò 'bottle' as shown in (80b). In such context, the numeral is used to count the number of 'bottles' and not of 'water'.

(80) a. *Tade dà ìyí ùji.

Tade buy two water

b. Tade dà ìyí ìgò ùji.

Tade buy two bottlewater

'Tade bought two bottles of water.'

c. Tade dà ìyí ùji.

Tade buy two water

'Tade bought two water.'

The example in (80b) shows that ìji 'water' is preceded by a measure word igò 'bottle' in order to enable the mass noun to be counted. However, there is an exception to this fact, the example in (81) is well-formed despite the occurrence of the numeral with the mass noun. I claim that the numeral as used in this context counts the drops of water and not the water itself.

$$
\begin{aligned}
& \text { ìyí ùji kẹ́rẹn úrẹ́ } \\
& \text { two water drop roof } \\
& \text { 'Two drops of water dripped from the roof' }
\end{aligned}
$$

The numeral iyi' 'two' occurs with a bare mass noun to form the plural version, in essence, the mass noun does not need otúro to be plural. ${ }^{58}$ Further research is required in this area

\footnotetext{
${ }^{58}$ The example in (81) is like the assumptions in Ajíbóyè (2005) in which he argues that the numeral in Yorùbá are markers of plurality in the sense that they can transform a singular noun into a plural form (iii).

(iii) Mo ra ìwé méjì

1sGbuybook two

'I bought two books.'

(Ajíbóyè 2005:228)

However, this work does not take numerals in Ògè as markers of plurality, instead the claim is that they are classifiers that allow mass noun to be counted (numerals as described here are something like a modifier that occurs freely with
} 
in order to establish the position of the occurrence of the numeral in the nominal spine. For my analysis in this dissertation, it is enough to show that otúro is not compatible with mass nouns as it is with count nouns as shown in section 5.4.

On the other hand, the example in (82) shows that the (in)definite article in Ògè is compatible with mass nouns. In such context, the articles do not mark the mass noun for singular but rather for definite or indefiniteness.

(82) İ̀ári/íkín íchá sí úrún àgbàlá

DEF/INDEF sand PP inside compound

'The sand is in the compound/An unspecified sand is in the compound.'

If the NP is interpreted as definite with the use of ikári 'the' then the NP gets a definite interpretation, this means that there is a common background knowledge between the speaker and the hearer such that the speaker refers to the said 'sand' in the compound. Secondly, if the NP is interpreted as indefinite with the use of $i$ 'in 'a' then the NP gets an indefinite interpretation which means, it refers to an unidentified (unknown) 'sand'.

As pointed out in section 5.4.5., Ògè makes use of some quantifiers in its structure; igào 'all/every,' ikúwó 'some.' These quantifiers are also acceptable with the mass nouns in Ògè as shown by the grammatical expressions in (83). While the ungrammatical example in (83c) shows that the (in)definite articles do not occur with the quantifiers as shown by the ungrammaticality in (72c) for count nouns in the context of the (in)definite articles and the quantifiers.

both mass and count nouns in Ògè). 
(83) a. ikúwó íchá sí èégé

Some sand PP there

'Some sand is there'

b. ìgào ùji si èégé

all water PP there

'All water is there.'

c. *ikín/Ìkárí ikúwó íchà sí èégé

INDEF/DEF some sand is there

The discussions of the quantifiers in this section further shows that unlike English, the mass/count distinction in Ògè is not subjected to selectability. There are no quantifiers that are sensitive to this distinction. I further support this by showing that other quantifiers like ìyẹnyẹn, few, òpọ, 'many' are also acceptable with either count/mass nouns.
a. Ọ̀pọ íchá sí úrùn oòsírí
b. Íyẹ̀nyẹ̀n ùji sí úrùn oòsírí plenty sand is PP compound little/few water is PP compound
'The compound is full of sand.'
'Little water is in the compound.'
a. Ọ̀pọ ẹ̀nẹ sí úrùn oòsírí
b. Íyẹ̀nyẹ̀n ìsí sí úrùn oòsírí plenty person is PP compound 'Many people are in the compound.' little/few yam is PP compound 'Few yams are in the compound.'

Most importantly for my discussion in this section is that otúro is not compatible with mass nouns and the interpretation of the (in)definite articles in the context of the mass nouns is not a marker of singular but of either definite specific, indefinite non-specific, indefinite specific but crucially not singular (in)definite. 


\subsubsection{Temporal Nouns (òtúro is sensitive to the specific interpretations of temporal}

nouns)

Asides mass nouns in Ògè, there are some sets of count nouns that do not occur with otúro to form plural, these are nouns that signify periods of time, year, month, week and hour and a measure word like 'kilo.' These nouns are not acceptable with otúro when they are used to form a sentence, but they are fine with oturro in isolation as shown in (8687).

(86) a. òtúro ìgú

PL year

'years'

b. òtúro wákàtí

PL hour

'hours'

c. òtúro ọ̀sè̀ PL

week

'weeks'

(87) òtúro iwọ̀n

PL kilo

'kilos'

Otúro is not acceptable in the first part of the sentence in (88) with the temporal noun, otúro is only grammatical when it is used in relation to a temporal noun as shown in the second part of the sentence. 
(88) Í dọwẹ (*òtúro) ìyí ìgú, Í gbádun òtúro ìyí ìgú nì dọwẹ 1SG stay two year, 1SG enjoy PL two year COMP. stay

'I stayed for two years; I enjoyed the two years that I stayed.

The first part of the sentence is not grammatical with the overt realization of oturo while it is grammatical when it is used to refer to an old information. The grammaticality of otúro in the second part of the sentence further proffers support for the analysis of otúro as an item that is sensitive to the marker of definiteness $\&$ specificity. The next section gives the syntactic assumptions for mass nouns in Ògè.

\subsubsection{Mass nouns in Ògè, towards an analysis.}

As proposed in section 5.4.1., the number interpretations of count nouns come from the interpretable number feature on Num in the syntax of Ògè which translates into the vocabulary items in D. The analysis that I put forward in this section is to show how number interpretation of mass nouns is derived. Since mass nouns do not require otúro to be plural, what comes to mind is that the NumP does not project in the structure of the mass nouns in Ògè as shown in (89). This option comes to mind based on the assumption that the D-head is sensitive to number interpretations and that the number interpretation of the noun comes from the number interpretation feature on Num.

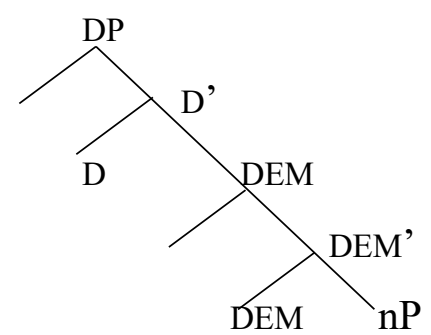

No NumP in the structure of mass nouns in Ògè 
Based on the absence of the projection of the NumP in (89), the D-head will not get a number interpretation, the noun is either left with numerals or other morphemes that signify abundance, i.e., 'classifiers' or 'quantifiers.' Thus, in this system, what gives rise to the mass interpretation of the noun is the absence of NumP or what gives rise to the definite mass interpretation is the presence of D. The assumptions advocated here are not far from Borer's (2005) system - in the sense that in Borer's system, the division interpretation of the noun is associated with the division layer (classifier phrase (CIP)) which takes the root and gives a divided output. ${ }^{59}$ In the same vein, here, the idea is that the division layer like the NumP which is the locus of number interpretations enters into agreement with the D-head for the purpose of number interpretations of the noun.

Based on the discussions and analysis of mass nouns in this section, we could say that Ògè presents one of the basic properties of the count-mass distinctions because mass nouns in Ògè do not combine with the plural morphology to form plural. Following the observations in this section on the restricted distributions of otúro, in the next section, I provide evidence that shows that òtúro is not compatible with pronouns in Ògè.

\subsubsection{Pronouns in Ògè ${ }^{60}$}

In the literature, various studies have been carried out on the strategies used to mark plural on pronouns. Additionally, it has been established that languages use pronouns (especially the $3^{\text {rd }}$ person plural pronoun) to mark plural. To this end, this section

\footnotetext{
${ }^{59}$ In this system according to Borer (2005), roots are not specified for being either mass/count which means that this distinction is created in the division layer which takes the undivided material that is denoted by the root and gives a divided output - importantly for the option of no NumP projection, roots are mass and the absence of the NumP (locus of number interpretation) will yield a mass noun.

${ }^{60}$ This section is a response to the question of one of the reviewers of the abstract that I wrote on oturo requesting to know how pronouns in Ògè are marked for plural. It is common for some languages to make use of a plural marker to mark plural on pronouns. In Ògè, pronouns take different forms depending on the referent (singular or plural).
} 
discusses the pronouns in Ògè and shows that òturo is not related to pronouns and that òtúro does not pluralize pronouns in Ògè.

It is very common for languages to distinguish person and number in pronominal. In (97a), the pronoun $\dot{u}$ refers to a singular entity while $\grave{a}$ in (90b) refers to a plural noun. ${ }^{61}$

a. Ú í vá.

3SG PROG. come

'she is coming.'
b. À í
vá.
3PL PROG. come
'They are coming.'

Ògè marks tense with independent morphemes: rá marks future on the verbal item (91a), $i$ marks progressive (91b) while sẹ̀ marks past perfect tense (91c). The mentioned items do not change the forms of the verbs; the verbs in Ògè have the same forms in all contexts. The copula verb $s i$ 'is' is not always realized in the sentence in Ògè, hence the gloss in (91b).

(91) a. Túndé rá vè ùwà

Tunde will go farm

'Tunde will go to the farm.'
b. Túndé í
vè ùwà.
Tunde PROG. go farm
'Tunde is going to the farm.'

\footnotetext{
${ }^{61}$ I follow Cysouw's (2001) analysis that Plural pronoun refers to groups of singular participants. According to this analysis, these groups are inherently plural as they consist of more than one participant. The importance of these recategorization from plural into group for my discussion in this work is that it allows for the assumption that the singular and the group categories are 'unmarked for number.' This conclusion is plausible because, the plural marker does not occur with pronouns in Ògè.
} 


\section{c. Túndé sè vè ùwà \\ Tunde PAST-Perf go farm}

'Tunde has gone to the farm'

It is important to note that pronouns in Ògè are only specified for person and number features. Pronouns in Ògè consists of three persons: first, second and third, table 1, shows the singular pronouns.

\section{Table 5.1: Personal singular pronouns in Ògè.}

\begin{tabular}{|l|l|l|}
\hline Person & Subject & object \\
\hline 1 st person & í & ràn \\
\hline 2nd person & á & rìn \\
\hline 3rd person & ú & $\varnothing$ \\
\hline
\end{tabular}

The pronouns in Table 1 are equivalent to the singular pronouns in English and they only refer to singular entities. The difference lies in the form of the third person singular object, the form is not phonologically specified. The reason is that the form of the third person singular pronoun changes with the context. i.e., $i$ da $\dot{a}$ 'I bought it' $i$ fehen en 'I liked him/her' Í sue é 'I called him/her'. The third person singular pronoun takes the form of the final vowel of the preceding element.

The plural counterparts of the pronouns in Table 1 are given in Table 2. An example of the use of some of the pronouns is given in (92) to show the contexts of occurrence of some of the pronouns.

Table 5.2: Personal plural pronouns in Ògè.

\begin{tabular}{|l|l|l|}
\hline Person & Subject & Object \\
\hline 1st person & ó & wò \\
\hline 2nd person & ẹ́ & mẹ̀ \\
\hline 3rd person & à & va \\
\hline
\end{tabular}


(92) a. Ó bẹ̀ vá.

1PL beg 3PL

'We begged them.'

b. À bẹ̀ mẹ̀.

3PL beg 2PL

'They begged you (PL). ${ }^{92}$

Òtúro is not needed in order to get a plural interpretation of the pronouns in Ògè. ${ }^{63}$ In addition, plural pronouns do not perform any other function in Ògè than to convey the plural interpretation of the pronoun involved. i.e.,
a. Í bẹ rin
$1 \mathrm{SG}$ beg $2 \mathrm{SG}$
'I begged you.'

${ }^{62}$ The gloss in (92b) is like the interpretation of the associative case marker in Hungarian. The suffix $-e k$ is an associative marker which combines the hearer with other people.
(iii) János-ék
NAME- ASSOC
'John and associates,' 'John and his group (Cysouw's 2001:67).

The main difference is that the feature is encoded on the pronoun in Ògè and the pronoun mẹ does not combine with a proper name in Ògè.

${ }^{63}$ Cysouw's (2001:68) citing (Sohn 1994) for Korean and (Popjes \& Popjes 1986) for Canela-Kraho, a Gé language from Brazil, the author noted that these languages use a nominal plural marker to mark plural on pronouns.
(iv)a. Capi te i-pupun b. Capi te me i-pupun (Canela-Kraho).
NAME PAST 1-see
'Capi saw me'
c. humre te me rop cahhyr
man PAST PLUR dog beat
'The men beat the dog'
NAME PAST PLUR 1-see
'Capi saw us (exclusive)'
(Popjes \& Popjes, 1986: 175)

For Korean, the plural marker -tul is a suffix which is suffixed to the noun, however, -tul is suffixed to the second person pronoun when the addressee is generally older than the speaker; the second person singular pronoun is tangsin and the second person plural pronoun is tangsin-tul.

Additional evidence is given in Cheng \& Sybesma (1999:537), who assume following Iljic (1994), that the suffix -men is affixed to pronouns in Chinese.

(vi) ni-men

$$
\begin{aligned}
& \text { YOU - MEN } \\
& \text { 'you (plural)' }
\end{aligned}
$$

Although, there are discrepancies on the use of -men as plural marker in Chinese: Li \& Thompson (1981:40) refer to it as plural suffix while Iljic (1994); Cheng \& Sybesma (1999) refer to it as a collective marker. The relevance of this discussion to this work however is to show that pronouns in Ògè do not occur with such markers that mark more than oneness. The claim that I make in this work is that, pronouns in Ògè are inherently specified for number, i.e., singular or more than one (a group of individuals). 
b. Ó bẹ̀ mẹ

$1 \mathrm{PL}$ beg 2PL

'We begged you.'

A third category of pronouns in Ògè apart from the singular and plural forms mentioned in table 1 and 2, exists. The third category is referred to as emphatic pronouns. ${ }^{64}$

\section{Table 5.3: Emphatic pronouns in Ògè}

\begin{tabular}{|l|l|l|}
\hline Person & Subject & Object \\
\hline 1st person & èmí & éwò \\
\hline 2nd person & ọran & ẹmẹ̀ \\
\hline 3rd person & úwọ̀n & àvá \\
\hline
\end{tabular}

Emphatic pronouns are different from the pronouns in tables 1 and 2 in one significant way: emphatic pronoun can be focused ( $94 a$ and $b)$.

(94) a. Ọ̀ran úwọ̀n dà ìsí

2SG be buy yam

'It was you that bought a/the yam.'

b. Àvá úwọ̀n ú rì

3PL be $3 \mathrm{SG}$ see

'It was them that he saw.'

(95) a. Ú rì va

3SG see 3PL

'He/she saw them'

b. *va úwọ̀n ú rì

The expressions in (94a and b) represent both the singular and plural forms of the emphatic

\footnotetext{
${ }^{64}$ The term emphatic pronoun is used in the sense of Awobùlúyì (1978:12) who refer to this category of pronouns in Yorùbá as nouns because they occur in the same contexts as nouns. I used the same criteria of categorization for pronouns in Ògè.
} 
pronoun in focused positions. The example in (95a) shows the plural form of the personal pronoun in object position $v a$ 'them' while the emphatic form is àvá. The emphatic pronouns in (94a and b) both occur in a focused position: the example in (94a), is the subject focus while the example in (94b), is the object focus. The ungrammaticality of (95b) is an indication that the first and second categories of pronouns in Ògè do not occur in the same position as the emphatic pronouns. It is interesting to note that all six of the emphatic pronouns have a restricted distribution which are: focused, relativized and topicalized positions.

Following the standard assumptions in the literature, I claim that pronouns in Ògè occupies the D-head. The number feature of the pronoun in D is interpretable on Num. The interpretable number feature on Num is semantically interpreted.

Section 5.6. provides further evidence in support of the position postulated for otúro in Ògè.

\subsection{General discussions}

This chapter has been on the discussion of number marking in Ògè and the analysis of otúro as a plural determiner in which otúro is analyzed as an element situated in the Dhead, a position which is higher than the traditional Num(ber) Phrase. Some scholars Corbett (2000); Acquaviva (2008); Lowenstamm (2008); Kramer (2012); (2015); Kim \& Melchin (2018) are of the opinion that if a plural word is low, it would be more likely to be connected to animacy. The intuition is that a plural word in $n$ or below $n$ may show some idiosyncrasies, (not consistent on human, animate and inanimate). A typical example of this intuition is seen in Corbert (2000), in the animacy hierarchy in (96); Amharic irregular plural word (100-103) and the nP adjoined -tul in Korean as discussed in section 5.2.2.3. in (26) repeated here in (104). 


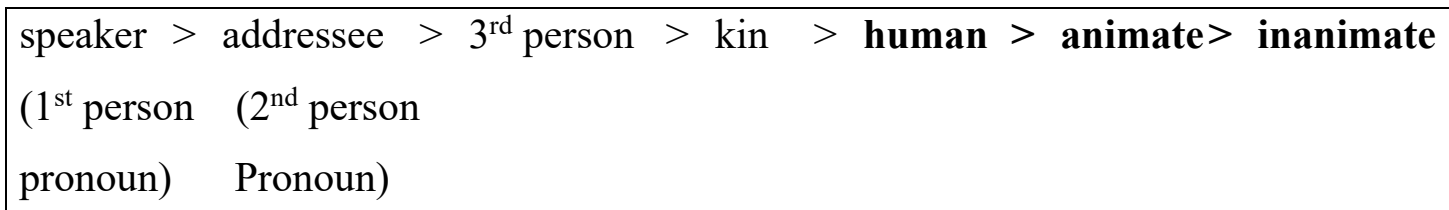

The bold items in the animacy hierarchy show the area of concentration of my discussion in this section. According to Corbett, if a noun at some point in the hierarchy can be pluralized, then all nouns above that point will also be able to be pluralized, for instance, if a plural word is compatible with an inanimate noun in a given language, such plural word will be consistent on both animate and human nouns. If such a plural word is compatible with an animate noun, then it would be fine on human nouns. A typical example of this is seen in Yorùbá. The plural word àwọn (Ajíbóyè 2005) is compatible with inanimate (107a), animate (107b) and human nouns (107c).

(97) a. àwọn ìwé

PL book

'books'

b. àwọn ajá

PL dog

'dogs'

c. àwọn èyàn

PL person

'people' 
In addition to the interpretations of the pluralized nouns seen in (97), no idiosyncratic interpretation is possible with àwọn as shown by the unacceptable idiosyncratic interpretation of the plural form of angeli 'angel' in (98).

$$
\begin{aligned}
& \text { àwọn angeli } \\
& \text { PL angel } \\
& \text { 'angels' } \\
& \text { *‘an holy person' }
\end{aligned}
$$

Section 5.6.1. further explores the sensitivity of plural to animacy in Amharic and Korean, since there is usually some sensitivity to animacy in languages when we include both definite and indefinite interpretations, section 5.6.2. extends the discussion on plural sensitivity to animacy to definite and indefinite interpretations of BNs and plural nouns in Yorùbá, Igbo and Ògè. The purpose of the discussion in this section is to further justify the position occupied by òturo in the syntax of Ògè which is the D-head.

\subsubsection{Plural sensitivity to animacy in Amharic and Korean}

Sensitivity to animacy is seen in the plural formation in Amharic in which plural is realized in one of several ways: plural marking with ot $\left.\int t\right]$, this is analyzed as the regular plural marker in Amharic (Kramer 2012) as shown in (99).
a. k'al
word
b k'al- ot $\int \mathrm{t} \int$
words

The second strategy of plural marking in Amharic is through one of the following methods; the suffix of $-a t$ to the noun (100a), a different voweling (100b), partial reduplication (100c) and the use of both ot $\int t$ and the suffix -an (101). 

(100) a. k’al-at
words
b. känfär $\rightarrow$ känafir $\quad$ lips
c. wäyzaro $\rightarrow$ wäyzazirt ladies

(Kramer 2012:227)

(101) mämhir $\rightarrow$ mämhir - an - ot $\int \mathrm{t} \int$ - teachers

(Kramer 2012:228)

In the light of the example in (101), Kramer argues for different syntactic nodes as a host for the plural markers, the regular plural marker ot $\int t \int$ heads the Num-head because it is consistent across the pluralized nouns in Amharic and it only allows compositional interpretation of the noun (102b) while the other strategies of plural marking is argued to be the head of $n$ since they allow the idiosyncratic interpretations of the plural nouns (102c). The idiosyncratic interpretations of nafs with ot $\int t \int$ is not possible (102b) while this is possible with the suffix -at (102c).
(102) a. nafs $\rightarrow$ soul
b. nafs - ot $\int \mathrm{t} \int \rightarrow$ souls $\quad *$ small insects
c. nafs - at $\rightarrow$ souls, small insects

(Kramer 2012:230)

Kramer (2012) states that, NumP is a domain of regularity for word formation, whereas words formed by the combination of $n$ and the root will lead to idiosyncrasies. The domain for each of the levels in the syntax is shown in the tree in (103). 
(103)

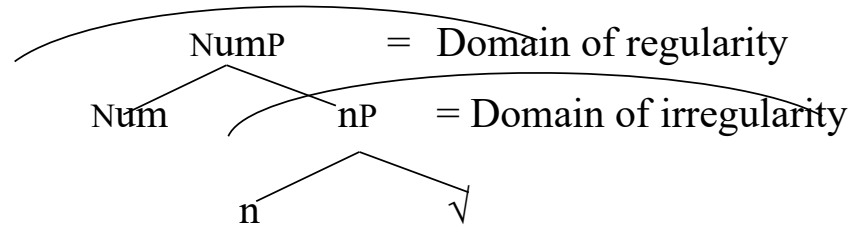

(Kramer 2012:229)

Evidence for the structure in (103) further comes from the hybrid plural system of Amharic involving both Num and $n$ as shown in (101). Kramer argues that only certain nominals can be inflected via irregular plural morphology whereas every nominal can be regularly pluralized by ot $\int t \int .{ }^{65}$ This is because nP allows for idiosyncratic interpretations of the noun while NumP only allows compositional interpretations. Therefore, it is expected that plural morphology that occupies a position which is lower than the NumP will be sensitive to animacy. We see evidence for this in some works like that of Acquaviva (2008) (n) and Wiltschko (2008) (root modifier) where the idiosyncratic plurals are heads that are closer to the root than Num. In Amharic, plural morphology that occupies the nP domain is not consistent with the plural form of nouns - such plural morphologies are called irregular because they are not compatible with some nouns (in a plural context) but they are found not to be fine with some nouns (this either leads to a marked form of the noun or outright ungrammaticality). ${ }^{66}$ The idiosyncratic nature of $n$

${ }^{65}$ Kramer (2012) supports the claim of the split plural in Amharic by arguing that irregular plurals vary with respect to gender features, for example, -an is used on masculine while -at is used on feminine.

(i) a. k' iddus-an 'saints' (masc.pl. or mixed group)

b. k' iddus - at 'saints' (fem.pl.)

The regular plural on the other hand is consistent on both masculine and feminine nominals as shown in (ii).

(ii) a. bet - ot $\left.\int \mathrm{t}\right\}$ houses $\quad-$ masculine

b. agär - ot $\int \mathrm{t} \int$ countries - feminine

${ }^{66}$ An example of the ungrammaticality of an irregular plural morphology on nouns is seen in (iii) as shown in Kramer (2012:231).

Singular

(iii) Mänäk ${ }^{\mathrm{w}} \mathrm{se}(\mathrm{it})$

Monk(-FEM)

The ungrammaticality in (iii) is because the feminine suffix -it and the irregular suffix -at cannot cooccur in syntax, the grammatical version of the plural feminine form is Mänäk $k^{w}$ sitot ot $t \int$ 'nun'. Invariably, the non-cooccurrence of the feminine suffix and the irregular suffix is because both suffixes occupy the same slot in syntax, which is the $n$ slot. When the noun is plural, it is acceptable for the plural suffix to occur at this slot because, the feminine suffix has a [- 
plurals is further supported by the behavior of -tul in Korean as seen earlier in section 5.2.2.3., repeated here in (104). Here, -tul is not compatible with all categories of nouns as shown by the marked expression in (104c).

$$
\begin{aligned}
& \text { a. sala-tul sey myeng } \\
& \text { person- PL three CL } \\
& \text { 'three people' } \\
& \text { b. chayk-tul sey Kwun } \\
& \text { book- PL three CL } \\
& \text { 'three books' } \\
& \text { c. ??kilin-tul sey mari } \\
& \text { giraffe- PL three CL } \\
& \text { 'three giraffes' }
\end{aligned}
$$$$
\text { (Kim \& Melchin 2018:13-14) }
$$

The plural suffix -tul occupies the $[\mathrm{Spec} \mathrm{nP}]$ position which is the locus of idiosyncrasy. Kim \& Melchin argue that -tul does not follow the assumptions in Corbett (2000) because there is evidence that $-t u l$ is compatible with inanimate nouns as shown in (104b), and intuitively, -tul should be compatible with a non-human animate noun in (104c), but this is not the case because of the marked expression that we see in (104c). Based on the idiosyncratic nature of $-t u l$, the authors argue that $-t u l$ is adjoined to the $\mathrm{nP}$ level because it is close enough to the level where animacy is encoded.

\subsection{2. (In)definite interpretations of a $\mathrm{BN}$ or a plural noun in relation to animacy.}

According to Manfredi (2018), plural interpretation of BNs is sensitive to animacy in Igbo

PL] feature which means in the context of a plural noun, the feminine suffix is not appropriate. 
because animate and inanimate nouns in object positions are interpreted differently: the animate $\mathrm{BN}$ in object position in (105a') is interpreted as indefinite and definite (105a ") but not as a plural definite $\left(105 \mathrm{a}^{\text {'”) }}\right)$ while the inanimate $\mathrm{BN}$ in (105b) is interpreted as an indefinite noun (105b') and a plural definite noun (105b“).

(105) a. Ộ̀ nù nị tá

3S.NOM see-INFL dog

a.' $=$ 'S/he saw a dog'

a." = 'S/he saw the dog in question'

a. ${ }^{\prime \prime}=\# \mathrm{~S} /$ he saw some dogs/the dogs in question

b. Ọ́ hụ̀-rụ óche

1S.NOM see-INFL chair

b.' $=$ 'S/he saw a chair/some chairs'

b." = 'S/he saw the chair(s) in question'

(Manfredi 2018:13)

In Yorùbá on the other hand, the counterparts of the BNs in Igbo, óche 'chair' and ńkì tá 'dog', have the same interpretation for both animate and inanimate nouns. However, the interpretation of óche includes definite plural (105-b") which is absent for animate BNs in Yorùbá (106a“), a definite plural is only available with àwọ (106c"). This is supported by the fact that in the English equivalent of the expression in (106-c "), English would need a bare plural and a definite plural.
(106) a. Mo rí ajá.
1S.NOM see dog
a. ' = 'I saw a dog/some dogs'
a. ' = 'I saw the $\operatorname{dog}(\# \mathrm{~s})$ in question' 
b. Mo rí àga.

1S.NOM see chair

b. ${ }^{\prime}=$ 'I saw a chair/some chairs'

b. " = 'I saw the chair(\#s) in question

c. Mo rí àwọn ajá.

1S.NOM see 3P. dog

c. ' $=$ 'I saw some (individual) dogs.'

c. '= 'I saw the dogs in question.'

(Manfredi 2018:13)

Building on the assumption that each phrase in natural language is complex, Manfredi concludes that the plural marker in Yorùbá is not sensitive to animacy because àwon is not close to the level where animacy is encoded, i.e., the root or the little $n$.

If animacy sensitivity in plural marking is not a universal one, then the question is whether this property follows from some other independent features. Intuitively, we can assume that animacy is an inherent property of nouns or nominal roots. Coming back to Ògè, the question of course is 'is òtúro sensitive to animacy?' As mentioned earlier, BNs in Ògè are ambiguous between four readings; definite versus indefinite and plural versus singular reading. The paradigm in (107) explains this further.

$$
\begin{aligned}
& \text { (107) a. Í rì ópú. } \\
& 1 \mathrm{SG} \text { see dog } \\
& \text { a.' = 'I saw a dog } \\
& \text { a." }=\text { "I saw the } \operatorname{dog}\left({ }^{*} \mathrm{~s}\right) \text { in question } \\
& \text { a. }{ }^{\prime \prime}=\text { 'I saw some (unspecified) dogs }
\end{aligned}
$$



b. Í rì àga.
$1 \mathrm{SG}$ see chair
b. ' = 'I saw a chair.'
b." = "I saw the chair $\left({ }^{*} \mathrm{~s}\right)$ in question
b. '” = 'I saw some (unspecified) chairs.'

In (107a), the interpretation of the animate noun in object position will have the following readings, (in)definite $\left(107 \mathrm{a}^{\prime}\right.$ and $\left.\mathrm{a}^{\prime \prime}\right)$, a plural reading $\left(107 \mathrm{a}^{\prime \prime}\right)$ but not definite plural $\left(107 \mathrm{a}^{\cdots *}\right)$, this is also true in $(107 \mathrm{~b})$ for the inanimate noun. The examples in $(108)$ show the BN in Ògè in subject positions.
(108) a. Ópú sì èégé.
$\operatorname{dog}$ COP there
a.' $=$ 'The $\operatorname{dog}\left({ }^{*} \mathrm{~s}\right)$ is there.'
a." = 'A dog is there.'
a. '” = '(unspecified) dogs are there.'
b. Àga sì èégé. chair COP there
b.' $=$ 'The chair $\left({ }^{*} \mathrm{~s}\right)$ is there.
b." = "A chair is there.
b. ${ }^{\prime \prime}=$ '(unspecified) chairs are there.'

The animate and inanimate BNs in Ògè in subject positions do not require the plural marker to be interpreted as plural, but they require otúro to receive a plural definite interpretation. Plural nouns in object position will receive the following interpretations: plural definite (109a` and b') but not indefinite plural (109a“ and b“). 
(109) a. Í rì òtúro ópú

$1 \mathrm{SG}$ see PL dog

a. '= 'I saw the dogs in question.'

a. “' '*I saw a/the dog.’

b. Í rì òtúro àga

1SG see PL chair

b. ' = 'I saw the chairs in question.'

b. " $=$ '*I saw a/the chair’

There is no discrepancy between animate and inanimate nouns in Ògè, the diverge is rather with definiteness which supports the fact that otúro is not close to the root where animacy is encoded.

\subsection{Summary}

Based on the interpretations of nominal expressions with the presence of oturo, this chapter argued for òtúro as a plural determiner. Otúro occupies the D-head in the syntactic structure of Ògè. Despite appearances, this chapter showed that the elements in D get their number features from the Num-head which translate to the fact that NumP is projected in the nominal structure of Ògè. Otúro is a plural determiner that gets its number interpretations from the Num, òtúro does not modify roots; and it is compatible with all categories of nouns including the nominal attributive modifiers since they are also nominal.

Most importantly, this chapter argued that a BN in Ògè is covertly specified for a number feature but that BNs in Ògè have the nature of a general number because the Numhead is not phonologically filled. This chapter therefore concludes that in languages, the position of the occurrence of the element that is sensitive to plural depends largely on 
other parameters like animacy and the definiteness interpretations of the noun and not necessarily on the plural interpretation of the elements, i.e., -tul in Korean occupies the $n$-head, $o$ ' $o b$ in YM occupies the D position, the plural words in Halkomelem occupy the root position and so on. 


\section{Chapter 6 Summary and concluding remarks}

\subsection{Introduction}

The dissertation focused on aspects of nominal modification in Ògè with the aim of analysing its syntactic structure. The main conclusions of the dissertation are the following: (i) nouns in Ògè could be bare (ii) the adjective as a lexical category is not a universal category because they are derived from another lexical category in Ògè (support for this claim comes from the structure of the adjectives in Yorùbá) (iii) number marking in Ògè is optional but it is required in some contexts because overt plural marking is obligatory in a plural definite context.

\subsection{Summary of findings}

The dissertation started by showing that Ògè possesses the definite and the indefinite articles in its nominal expressions, but that they do not accompany the noun in all contexts. The question arises as to how to classify the NPs in Ògè - what are the generalizations that could be arrived at regarding the debates on the article and articlelessness in languages? To this end, the dissertation proposed that the definite and the indefinite articles in Ògè are realized in one of two ways: phonologically filled D or null D. This led to the conclusion that, $\mathrm{D}$ is the locus of definiteness, this means that irrespective of the status of the D-head (either phonologically filled or not), D is required to give its semantic impact in the projection of the NP.

Chapter 3 gave the analysis of the internal structure of Nominal Attributive Modifiers (NAMs). It argued that NAMs are nominal. Three pieces of evidence were provided in support of this argument, these were (i) the internal structure of NAMs (ii) the position of the occurrence of NAMs in the nominal expression and (iii) evidence from NAMs in Yorùbá. The chapter further showed that the predicative forms are stative verbs by 
highlighting some similarities between the predicative forms and the stative verbs in both Ògè and Yorùbá. The chapter concluded that the different structure of the predicative form in attributive position is related to the fact that Ògè lacks predicative adjectives from which it could derive the attributive form, what it has are stative verbs.

Chapter 4 provided adequate evidence in support of the modification structure of the merger of NAMs plus nouns. The chapter argued that attributives in Ògè perform more than one function in syntax; as a head or as an adjunct. First, the presence of the attributive is obligatory in possessive and genitive structures as shown in (1a, b). The absence of the attributive modifier in such expressions results in ungrammaticality or a change in meaning (attributives as heads) of the nominal expressions. Second, attributives are optional in a modification expression (2), (attributives as adjuncts).
(1) a. éswé ísínsín
b. íyẹ ikári àyẹ
House black sweetDET soup
'Black's house' or the house which belongs to Black' 'sweetness of the soup'
(2) a. ikári ígogoópú
DET old dog
'the old dog'
b. ígbààji ígbègbè ísinsìn ópú good small black dog 'a/the good small black dog'

Having shown that the function of an attributive in (1) is different from the function it performs in (2), the chapter emphasised that the linear order of an attributive and the noun is paramount in a modification structure: an attributive is restricted to the prenominal position and it is immediately followed either by another attributive modifier (2b) or by the modified noun (2a). The chapter proposed that the attributive in (2) is merged in a direct relation to the modified noun and that attributives in Ògè form a close class of lexical items. 
Finally, chapter 5 discussed the strategies of number marking in Ògè. It noted that number is optionally marked in the language. This suggest that a BN in Ògè has a general number. The overt occurrence of Òturo translates to the plural definite interpretation of the noun. Most importantly, the chapter argued that the locus of the occurrence of the plural morpheme in the extended projection of the NP is independent of its interpretation as a plural morpheme. Rather, its position along the functional spine of the NP is related to other parameters such as definiteness, specificity and animacy. The chapter proposed that the D-head is sensitive to number marking in Ògè which means, the D-layer performs a dual function of marking a noun for both number and definiteness. The chapter concluded that in certain contexts, plural nouns have more restricted uses because of the interactions between number and semantic features.

\subsection{Contributions to linguistics research}

The following are the contributions of this research from a formal perspective: Firstly, being the first work on the nominal domain of Ògè, it is my hope that this dissertation has brought interesting data into the theoretical discussion on the syntax and morphology of noun phrases, and that it will inspire future work on the severely understudied languages in the Benue-Congo and Niger-Congo at large. Secondly, BNs are not limited to articleless languages. Nouns in some languages are not obligatorily accompanied by the articles in all contexts. Thirdly, this study supports the arguments in the literature on the 'No predicative adjectives' and in general, 'No adjectives' in most of the languages in BenueCongo as argued by scholars like Ajíbóyè (2005); Awobùlúyì (1972), (1978); Cinque (2010), (2014); Dechaine (1993); Dixon (1982); Welmers (1973). Fourthly, the work 
shows the similarities between predicative forms of the modifiers and stative verbs in two languages, namely, Ògè and Yorùbá (predicative modifiers are syntactically statives in the two languages). Fifth, the study has shown that the occurrence of the high tone in Group I NAMs is independent of the vowel that bears it. In other words, the study supports the syntactic status of the high tone in Yorùbá as already established in Ajíbóyè, Dechaine \& Stewart (2003); Ajíbóyè (2005); and Manfredi (1992). Sixth, theoretically, this study presents evidence that shows that the projection of the NumP is required in a language in which the noun is not obligatorily marked for plural. And lastly, the plural morphemes in languages may be related to semantic parameters like definiteness, specificity and animacy. The study shows that the overt occurrence of Otúro translates to a plural definite interpretation of the noun.

\subsection{Suggestions for further research}

The dissertation by no means did not cover all the aspects of nominal modification in Ògè. Most importantly, it did not discuss all the NAMs that exist in Ògè. I highlight some of the aspects of NAMs that require further studies in sections 6.4.1.-6.4.2. I conclude this dissertation by suggesting that more work need to be done on the nominal modification of Ògè both in descriptive and theoretical analysis of the language.

\subsubsection{Nominal Attributive Modifiers (NAMs)}

NAMs are not restricted to identical forms to the predicative forms. The analysis in this dissertation focused on the NAMs that are derived from the predicative forms because of 
two reasons which are: (i) to establish that NAMs could be derived from a distinct lexical category, namely verbs, and (ii) to show that the derivation of NAMs has the same process as the derivation of nouns from verbs as shown in chapter 3, section 3.3.1.1. Further research in this area will concentrate on NAMs that have a distinct morpheme from the predicative forms, an example of this is given in (3).

\section{Predicative form}

(3)a. Ígé úwan sọn

DET child beautiful/handsome

'The child is beautiful/handsome'

\section{Attributive form}

b. ígé ígbàaji úwan

DET beautiful/handsome child

'that beautiful/handsome child'

The difference in the predicative and attributive forms in the example in (3) is like a case of suppletion. Further work in this area will establish if this is the right analysis.

\subsubsection{External syntax of NAMs}

Further research is required in the area of the merger of NAMs plus nouns in Ògè and in most of the languages in Benue-congo. For example, the lexical item corresponding to 'former' in Ògè which is tẹlè modifies the noun by occurring after an element $n i$ as the example in (4) shows.

(4)

$$
\begin{aligned}
& \text { usín nì tẹ́lẹ̀ } \\
& \text { king REL before } \\
& \text { 'former president' }
\end{aligned}
$$

An analysis has been given for a similar element $t i$ in Yorùbá in Ajíbóyè (2005) in which he argues for a reduced relative clause structure for the expression in (5). 
(5) Yorùbá

àrẹ ti tẹ́lẹ

president GEN before

'former president' (lit: the president of before)

Further work in this area will focus on such elements to see if there are more elements in this group in order to arrive at a conclusion about the claim in this dissertation regarding the direct modification status of NAMs in Ògè. 


\section{Appendix A}

\section{Some names of my language informants}

(1) The Owágè of Ògè

Age: 79

Ọba Alexandra Sànúolu Jimoh, Sẹ̀kẹ̀kẹkẹ Adòdó II.

(2) Èyésojú Oba

Mrs Beatrice Boboye

Age: 70

Occupation: Trader

(3) Musa Abdulbakai Olawale

Age: 35

Occupation: Contractor

(4) Mrs Ẹniọlá Jackson

Age: 57

Occupation: Trader

(5) Mr Balogun Adebisi

Age: 70

Occupation: Woodworker

(6) Apostle Prophet J.T. Aribisala

Age: 68

Occupation: Prophet 
Impressions from my fieldwork trips

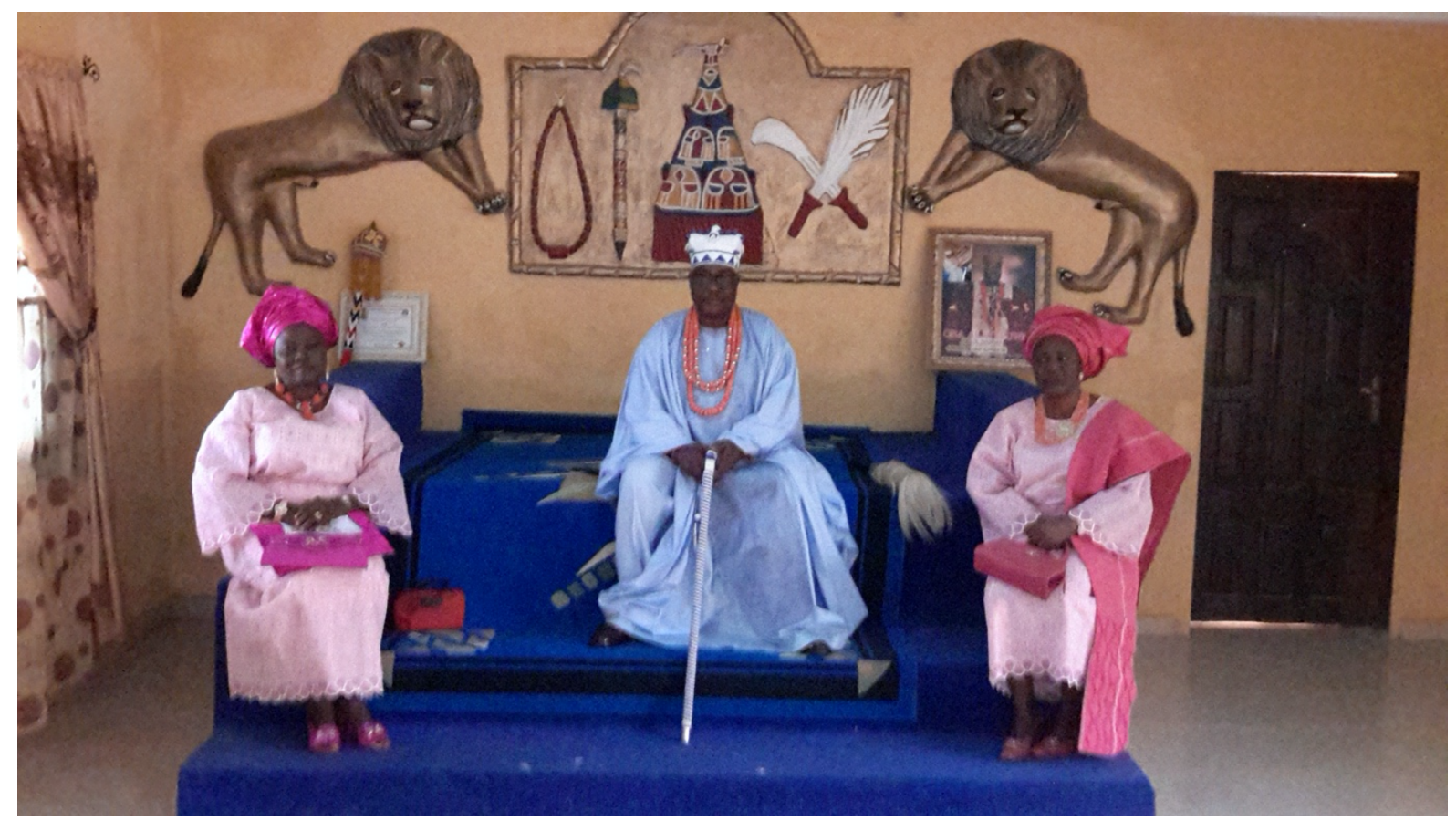

Owágè of Ògè (middle) and his wives.

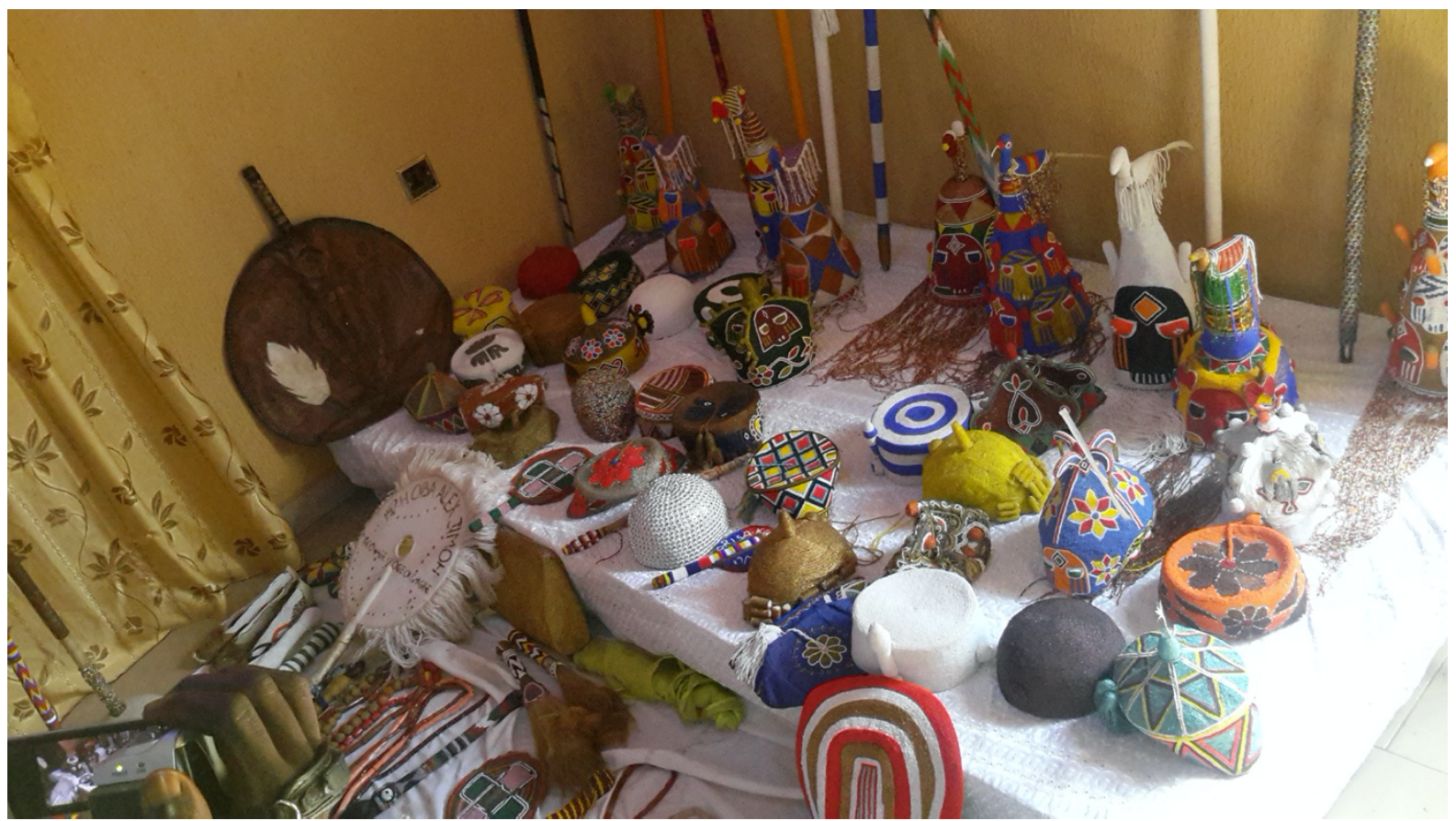

The items in the picture are called 'ẹrẹ' which means 'property'. The people of Ògè celebrate a festival every year to celebrate 'ẹrẹ' (a day set aside to celebrate the belongings of the kingdom of Ògè). 


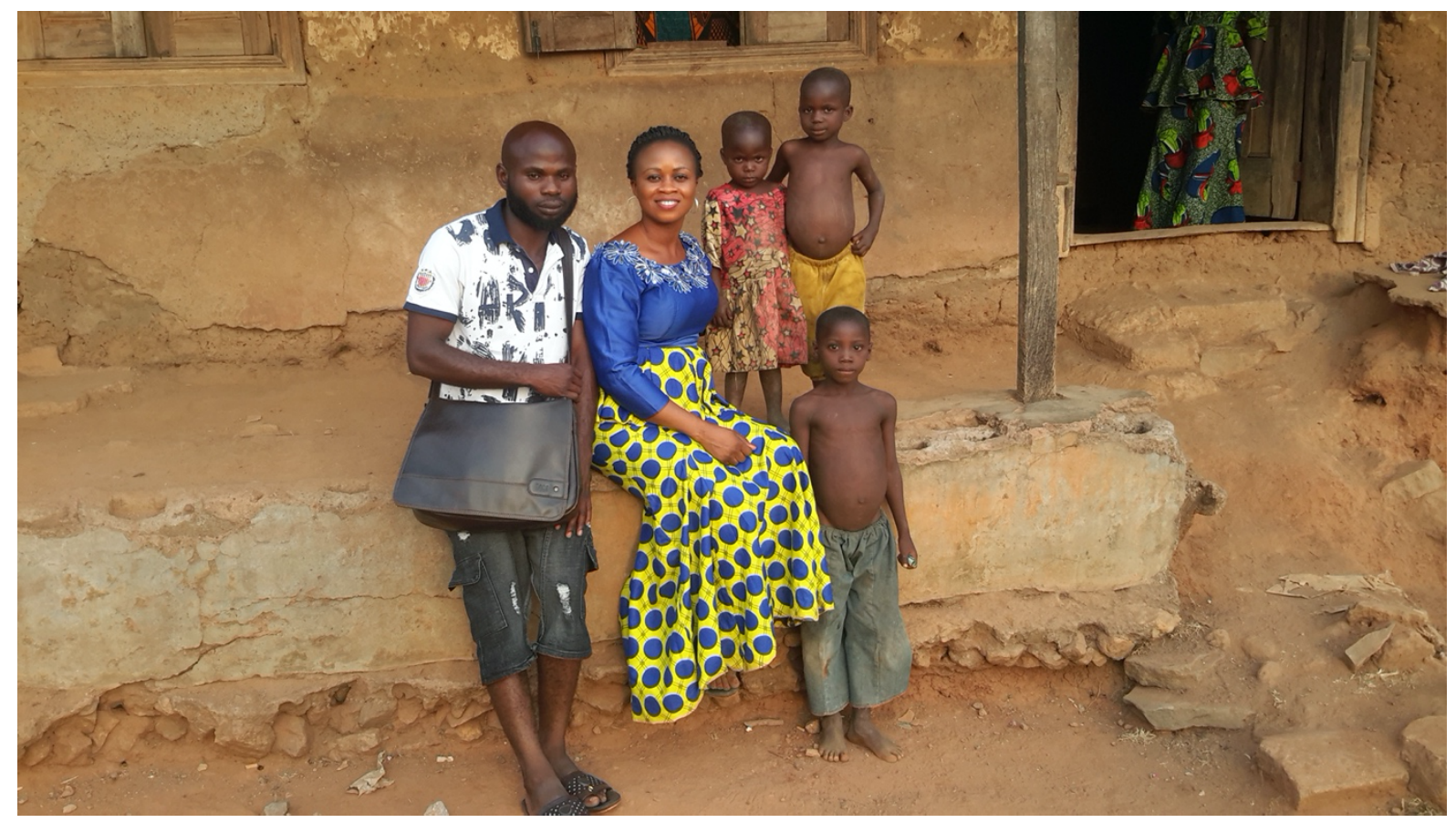

With Abdulbakai, my principal language informant.

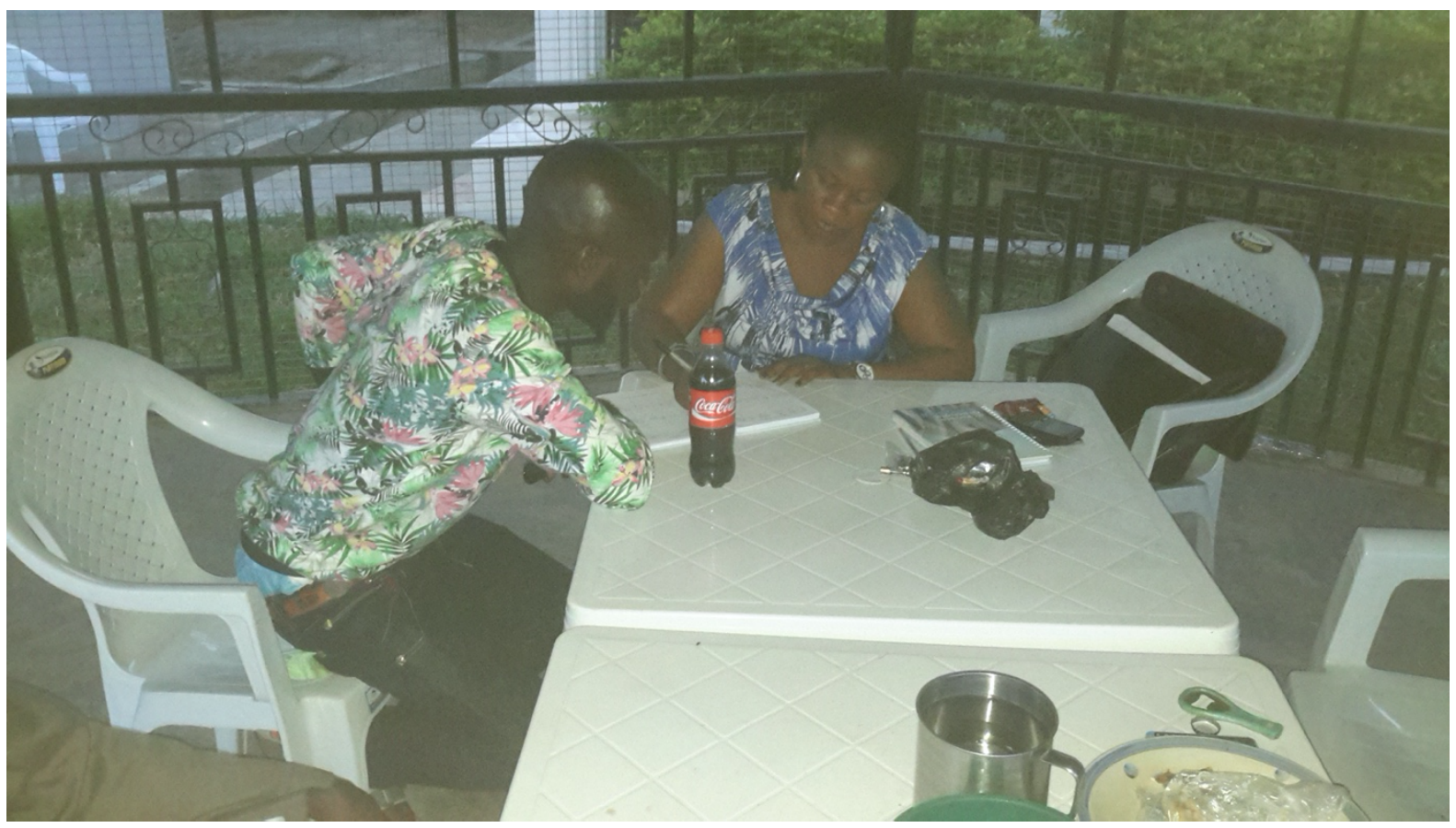

With Abdulbakai during one of the intensive word for word translation of some folktales. 


\section{Appendix B}

\section{Some short stories in Ògè without the glossing}

(For the full glossing, constituent labelling and the audio of the stories, please see https://adenugapriscilla.wordpress.com/folktales)

\section{Story 1. $\quad$ Èzízà uwan Elechui Sọn}

Òtórìn uwanrin inẹ chẹ eshin wẹe. Ifẹ naa peziza yán mẹ o, íba jiki ígé í kosẹn, í ba sẹ kòsẹn ẹn, die ba keri yin ira ajega mẹ̀.

Íghẹ úwan á sọn, ininẹ maa í gbe ígé uwan o. Ígé uwan áà bi dòóvá. Íghẹe ẹnẹ ba ikìi pe nu va dòóràn, ú ti hẹ ẹrẹ yẹ doorin. Íghẹ ẹnẹ ba idikiji pe nu va dòórẹn, ú ti ẹre yẹ doorin. Á hẹ mara ke yin uwọn uwan o?. Orun hẹ bi ẹrẹ úwọn ra gbì íghẹ́ uwan. Orun hẹ uwọn ra gbaa. A kirida kera ke nara gbaa. Ú hin nari goo.

Ú di ihẹ nọọ, íghẹ úwan í ve ùji, ú fẹ ná o kọ ùji. Orun va sendọjọ edidọ, á hẹ nu va dòórẹn, ú hin ẹrẹ̀?, nẹre va dòórín?, ẹrẹ a yoo doorin o!. Òran nẹ kẹ egbẹgbẹnẹkẹ e rín, nẹrẹ áà yoo doorín o. Ėégé á-ji-keva, orun vá hin áà yoo doorẹn?, ẹgbẹ rin na wa náàkẹ gbẹnẹkẹ dindinrẹn. Aaba-gẹ-doorẹn, gào ìhọ nẹ si-ji-rẹn ẹrẹ fẹ naa o sẹrẹn. Ú hẹ maa si họ nẹsijirin, ú hẹ ìhọ si jirẹn, ìhọ nẹsijirẹn gwẹrin o. Ẹrẹ̀n ra o kòsẹn gara ra chẹ uwanrin

\begin{tabular}{|c|c|}
\hline & \\
\hline i womi a meloo & Ero mi yeye \\
\hline & yeye \\
\hline mi a melo o & yeye \\
\hline ni abara jigijigi & \\
\hline abara kwekwen & Ero $\mathrm{m}$ \\
\hline & Ero \\
\hline & \\
\hline & \\
\hline & - Ero \\
\hline kwẹ & Ero \\
\hline & \\
\hline & Ero \\
\hline & $\operatorname{Er}$ \\
\hline & yeye \\
\hline & $-\operatorname{Er}$ \\
\hline & - Erc \\
\hline & Ero mi yey \\
\hline
\end{tabular}

U hẹ ẹrẹ yẹ dòórín ọran orun. Orun naale kaage gọọhọ ve ígé ẹrẹ a yo dòórín. Áà dòorẹ̀n, u hẹ hin. Orun hin gao ìhọ nẹre kaga rinrin Ighẹ nẹrẹ bari naa gbuwọ-ke ga ígéihọ, uku ijigehọ. Íghẹe nọo ẹrẹ ra gba rin éswé úsín, nẹra pẹgíri rin éswé úsín o. Á hẹ a ẹrẹ áà yoo gbuwọ kàn án.

Itumọ ígé eziza ran, úwan á ba di naa gba yiùran ai nẹ sọnu uwan o doouran o. Nu ba sẹ niiye mi ige uwan sọni ige uwan o dooran ijọni ígé uwan a si uwọn uwan chui wẹ Ihẹ ígé 
uwan a sẹ kero gwẹ. Ėyévà jẹga pe bi ìgào irurin sẹẹo ràn tanve naa o dòórán, maà chẹchin ke? Úwan bá di ina i gbàdá yán, à í gbàdá yán o. Úwan bá di na í gbu nghà yán, a í gbu nghà yán. Popopo màárẹ gíri ígé uwan o.

\section{Story 1b}

\section{The Beautiful Girl}

Children, sit down I want to tell you a story. When I begin to sing, you all must respond by singing along with me.

A girl was so pretty such that men desire to marry her, but the girl does not want to get married. Whenever someone shows interest in her, her response was always that she doesn't want to get married. People in the town wondered who her husband would eventually be. The Palm tree then said he will be the girl's husband.

One day, the girl went to the stream to fetch some water. The Palm tree hide in the bushes and on the girl's way back home, he told the girl to marry him. The girl was surprised and said, 'me'? I should marry you? I cannot marry you! At that moment, the Palm tree said 'You will not marry me? If you do not marry me, you must not touch anything that comes out of my body. And then he started to sing...

\begin{tabular}{|c|c|}
\hline & \\
\hline omi a meloo & Ero mi yeye \\
\hline & Ero \\
\hline omi a mẹlo o & Ero \\
\hline ni abara jigijigi & \\
\hline a kwẹkwẹn & Ero \\
\hline & Erc \\
\hline & \\
\hline & $-\operatorname{Er}$ \\
\hline & $-\operatorname{Er}$ \\
\hline vẹkwẹ & Erc \\
\hline & - $\mathrm{Er}$ \\
\hline & - Er \\
\hline & Ero \\
\hline & Ero mi yeye \\
\hline & Erc \\
\hline & Ero mi y \\
\hline & \\
\hline
\end{tabular}

The girl insisted that she will not marry him. The Palm tree then mentioned all the things that the girl must never touch again in her life if she refuses to marry him. He said which means, 'you must not touch things like broom, Palm Oil, Palm wine, Sago, Coconut and so on'. Say 'Yes' to my proposal or else, the day you touch any of the products that are produced from my body, 'You' will be beheaded at the palace but the girl insisted that she will never touch any of the things he mentioned. 
The story taught us that when a child is ripe for marriage, then the child must get married. And then the duty of the mother is to encourage the child to bring her suitor home for introduction.

\section{Story 2a.}

\section{Úwan Adidọ}

Eziza ran má rọ igiri íghẹ́ uchurẹn o. Íghẹ́ uchúren, ú vè ùwà ọnghọ, á fẹ na chọ ọnghọ, á dùwà ọnghọ, á í he ọnghọ, á ri ikan nẹ sì̀gìdì, á yá igẹnẹ sí gìdì, àjọni íghẹ uchurẹn jaànan másín. Àjọnì iyẹn igóò, ú hu ghoo mọmọ ràn, ú go itan ọwọ, á gèhéwọ, á gowájù, á gòsun, áà rínẹsue ínẹ gwá rèn. Ú hín ọran inẹ ígwa mi rin o niyaà rí rin o, ú hin ìjọ ná bá yí íchúí ìdì naà yóúngbẹ o. Ígé iyẹnnọ ige ànẹsọ, á í nẹ sọ. Ú mà wá vá chu ígé úwan ú ma sì èléchui o. Úsín ji vá hẹ ẹ̀rẹn úwọn ma ra gbì ígé úwan o, ighẹ úwan aà sì yóóungbẹ, ósodì. Úsín nọọ vá gbi íghẹ úwan nọọ, úsín sì sẹ sxku uchurẹn sí éswe, ú gbì íghẹ́ úwan agba a ó pá ugu eswe o. Usin bá gẹ si éswe, nú bá kọ ìhọ ná kè naàsọn, ígé ugu tì hin ígé uchurẹn úwọn kéé, ígé úsín tí hin ígé úwan úwọn kéé.

È̀̀gè kevá di íghẹ́ nọo usin aà vá sí éswe, àjọnì úwan usin maa vá pu o, Daodu usin ku. Àjọni ígé ugu, usin vá pọọ á hin maà pu íghẹe uwanrin? àjọni ígé ugu vá dahun pé ẹ̣ ràn ìhọ yoo ke ígé úwan, eesi ìhọ na gbà sí eswe úwọn púú? Ėègè úsín keva dahun pé na gbì ígé ùwan náà gbà vè íchúi ìdì, na ó pu ígé úwan sièégé.

Àgbi ígé úwan no ívè, agbà ívè, ú di ọlọ idi ágbà yî́, ágba yiiriyî́, ú yirida, ú yiri-nẹ, ú yirítọn, ú yirifà, ígé irifà á hu ke deega o nghbu, á dọwen, á vá ro pe a o sẹ dèé, a tii, á nù sọnrin. Eégé ó jikeva iyirichui, á diri chui á hen sọnnẹrẹ ngbẹ o, èégé a ke he nugbẹ ìhọ nú bárà nghbẹ. Àjọni ú hin aà sẹrẹn dédé ísodii. Á he ìjọnù mọmọ rèn yẹn-yẹrẹn, ú vòwà ọnghọọ, nu í he ọnghọọ, ú jànà másín ẹrẹ vá gwa mọmọ rẹn pe ngwo mọmọ rẹn, á he èégé èyévà kemejugo itọn ọwọ, áàrinẹ í gwá, ú mẹju kèhé, aà rinẹ í gwa, ú go wájù, aàrinẹ ígwa, ú gòsun, aàríne ígwa, á hẹ ihọne kerin nẹrẹ àgẹ̀ yóńgbẹ aà maa vege o. Á hin ùran ína í gun parẹn éswe, aà si ẹrẹ̀ úwọn ike gao ina ẹrẹ ikeroo, ugu rẹ̀n, úwọn íke o, ugu rẹn. Á hẹ úwan naà pú, úwan usin náà pú, á hin ugu rèn úwọn pu ígé úwan áà sệrẹ̀n úwon pú o, á hẹ ugu rẹn uwọn puu. Ėégé úwan ke he ugu rin úwọn pu úwan, á hin hin. Eégé a ke gbìge úwan lìsì sí éswe. Á vá gbi ìyálé ve ìtèrègó, ìyẹni pé ọ̀ran úwọn í purú uwontú nà í gunran pá úwọn úwan, áva gbí igiri ìyálé, á pẹẹ sí ìtèrègó o.

Ìhẹ̀ níge èzízà ran nú vè yán a yẹ nẹnẹ so nuuri sxuan ààjì, ààjì ààjì ígé ugu ri sùán o.

\section{Story 2b The story of the dumb child}

My story centers on a pregnant woman. The woman went to the farm to fetch firewood. At the farm, as she was about to pull a branch from the tree, she fell heavily to the ground on her buttocks. And then, the fetus in her belly said, 'sorry my mother' The woman looked to the right, she didn't see the person who greeted her. She looked to the left, she looked to the front, she looked to the back, she didn't see the person that greeted her. She then said, 'YOU' that greeted me that I couldn't find... until you climb seven mountains before you will be able to talk again in life. After the incident, her pregnancy started growing, it was developing and then she delivered a baby girl. After a while, the girl grew 
into a beautiful girl, but she is dumb. Because of her beauty, the King got married to her and she moved into the palace where the first queen lives. Whenever the king is not at home and something bad happens, the first wife will report that it was the dumb wife who did it. The king is always amazed that his beautiful wife is capable of such an act.

One day, the king went out as usual and then the king's son died before his arrival. When he came back, he asked for the person responsible for the act and quickly, the first wife accused the dumb wife! At that moment, the king ordered that the dumb wife should be made to climb seven mountains and then she should be beheaded on the seventh mountain.

They took the dumb girl to the first mountain, she climbed it. She climbed the second one, she climbed the third one, she climbed the fourth one, she climbed the fifth one, she climbed the sixth one and then she breathed heavily and stopped. The people thought she was tired. They pushed her to continue the journey and insisted that she should continue to climb the mountain. After that, they climbed the seventh mountain and suddenly, she started to talk, and she explained how and why she became dumb. She added that it was the first wife that committed all the atrocities in the palace. She said the first wife killed the Prince. At that moment, they all realized that the first wife is guilty of all the evil deeds in the palace, and they took the first wife to a place called 'itẹ̀règó' where she was beheaded.

That is the end of the story.

\section{Story 3a.}

\section{Ọ̀ran}

Ígé ọranrochurẹn, á shí nda úwan. Á bá sere vàájá, uchurẹn bá vàájá, nuran vòwà.

Nu bá di ẹrẹsẹn, ígé ọran ti hù vádí, unọ va uwọn ju Aóbẹ, nú ba vádí uwẹẹudọ un kọkọ hun sirọmi. Ú ti he se nẹrẹ hún uwẹne ẹdọ irin sirọmi, ú tì he nu hun sirọmi nu íbá yóó hun sirọmi. Ú ti hun sirọmi, u ti o vè. Nú bá si di íchúí, ijọ̣nù ú vá úráaroo, uwọn sira vádí eerí. Ú tì sì kero kòsẹn, unọ ti hẹ ná bá yoo hun sirọmi, hun sirọmi naa ri vee, ú tí si hun sirọmi. Ero kekekekee a hun iro sirọmi woo.

Uji va dẹrẹ, uya ma va ígé ochurẹn inẹ uwan wo do si ígé eswe ro, ini vo gbe éswe tiji. Kiidẹ keive, a i lawan wẹ nẹ vádí nẹ wuùmá úwan? Buwan mẹẹ sẹtan, a hẹ hín a hẹ ọran $\mathrm{o}$, ọran ochurẹn sẹe vàájá íchúí ọran uran sẹe vòwà $\mathrm{o}$. E chechin si éswe o ẹrẹsẹn nẹe yurẹn. Uchurẹn gbì ápásádà, nuran gbì ìgbègbè da. Ájíva kero ke. Ígé ọran vádí, a hẹ ọran uwẹdọ ọran wọn pọ she nẹrẹ sirin rọmi Ye! A ba yoo sirẹ rọmi, naa sirẹnrọmi. Duke hẹ nẹrẹ hu si ésín úlé shisẹ urẹ ati ushi, a gbi apásá, ochurẹn gbi apásá, a sẹe maa uran gbi ìgbègbè a sa ji ígé ọran ku. Ava la ígé igo ọran, á vá ri íchúí pọ sutuwo. Inẹ uwẹdọ nu ikọkọ u tẹ igo uwẹdọ sẹ ku.

Inijo naa, á bá vè áájá, á ve ùwà avàdí, núba kọ uwanrin naá ri, ẹ sọwọ nẹẹ ri nusi Taye, ẹ sọwọ nẹri Taye yan mi? E yẹ ri Idowu yan mi hun sen? Inijọ naa, unun irinẹ eji ke íwùùmá uwan $\mathrm{o}$, nu ba ve áájá, vòwà ávádí, nu ba gẹ ruwan, u mara wuumá uwan o.

Ihẹ nudọwẹ si gwẹro 
A couple had nine children. Whenever the woman is away to the market or the man is away to the farm, a bird called Aóbe do come to the house to meet the children. The bird asked the youngest child, should I swallow you? and then the girl said if you can swallow me, swallow me! She swallowed her and flew away. The following day, the bird came at the exact time she came the day before and asked the second to the last born, should I swallow you? The child said, if you can swallow me, swallow me. She swallowed her and flew away. This was how the bird repeats her journey everyday till she had swallowed eight out of nine children.

One day, their neighbor called the attention of the couple to the incident and inquire why both (husband and wife) do not care about the welfare of the children when they come back to the house in the evening. She instructed then not go out the following day that the bird will come again with the aim of swallowing the last child. The following day, the woman took a flat wood and hide in the roof while the man took a short stick and hide in the roof. The bird came at the usual time and asked the child if she should swallow her. The child responded that 'if you can swallow me, swallow me'. As the bird was about to swallow her, the couple jumped down from the roof and hit the flat wood and the short stick on the bird's head and it died. They cut the bird's stomach open, and two out of the eight children were dead.

Since that incident, whenever the parents are not at home for a long period of time and they come back home, it is customary to ask about the welfare of the children. Questions like, where is Taye? Who saw Taye around? Are always asked from the people around or in the neighborhood.

That is the end of the story.

\section{Story 4a.}

Agógó

Íghẹ ni èzízà rán rín da rẹ̀ ìghẹ urán ròchurẹn, á chúí íghẹ ída úwan, ididarívà sì eléchui. İgào ígé ìgú, İgào ígé ìgú úkúnẹ áà réyín váà. Á sú ọjọ ìgú, gào igwé dèdè yin ígé úwan sẹ uturọ uwánrin úkúnẹ áà ràn án. Á ó vè éswé, á dí éswe, á gọ́rẹn ùwà ộnghọ. Agọgộ vá vè á ó gbẹ ída akẹ̀kẹ́, á vá vò úrún ìhù ìhẹ iná à ke ká rií. Uwẹ̀dọ kọjá, ú súan akẹ̀kẹ́ wẹ́, ú dé eyin onọo, á hẹ Òpobípobì ẹ̀rẹ má ríi akệkẹ́ o. Irìyí sì kọjá, á sì di éyín inẹ unọ, ẹ̀rẹ ma ri íkín akệkệ. Irída sì kọjá á sì di éyín inẹ ùnọọ. Á ó kọjá á ó vòwà.

Agọgộ mà sìva éswe o, á dérèrè á lagogo 'kókókó'. Á hẹ ọjọ náa sue òrúngọ ro nu usin sì sùkù lìsì sùegu ojọ $\mathrm{o}$. A mà sue ọjọ $\mathrm{o}$. A ma hẹ ini ìgào ìgú deyin idida úwan elechui. Úkúnẹ áà màarin eyin vá o. Agọgọ̣ hẹ ẹ̣rẹ̀ ràn án, á hẹ uwọn ẹdọ á hẹ úwọn jù Òpobípobì, á hẹ ìiriiyìí, á hẹ úwọn jù Àrì̀àgosè, irída úwọn jù Alébíosù. Úsí atúle, igú vá wúwa ìmá, séyín nú uwan mẹju gwẹro? A hẹ eyin na và o yawa ju gwẹro. ìhẹ nu Agọgọ́ keke go ididariva gwẹro nuùsi ìyàwó Agọgọ́ 0 .

Níghẹ nọ̣ọ̆, úwọn ma se ni ẹnẹ isi eyín yan úwan o. Titiboy úwan ma sẹri sue úwan o, íghẹ ni ìkári alọ ran dasi gwẹro o 
My story centers on a couple. They have three daughters and no one in the town knows their names. The couple picked a date for the people in the town to guess their names, but no one was able to answer the question. After the event, they all went back home disappointed. The following day, the three girls went to the farm to pick some firewood. Tortoise by its characteristic nature, made three beautiful bicycles and laid ambush for the girls. On their way home, as the youngest girl was about to pass through the bush part, the Tortoise threw one of the bicycles on to the main road. The girl was surprised and called her sister by the name 'Òpobípobì' and said, 'I saw a bicycle'. The Tortoise also threw another bicycle to the second child as she was about to pass through the bush. She also called the name of her sister and said, 'I saw a bicycle'. Then the Tortoise threw the last bicycle to the last child and she also mentioned the name of the last girl.

Later, the Tortoise went back home and rang the bell 'kókókó' requesting that the meeting that was called few days ago should be called again because he has an answer to the question. A date was picked, and the town gathered in the palace at the chosen date. The Tortoise then came out and announced that he knows the names of the three girls. He said, 'the first girl is 'Òpobípobì', the second is 'Àríràgosè' and the last girl is 'Alébíòsùn'.

Since that day, it has become customary to name a child after birth and make the name known to the people. A child is not called something like Titiboy but a real name.

Story 5.

İjàn, İjàn o - ó rèjàn

Ikún ì pá pata ijọ èyé rèjàn ó mọn pá pata o - ó rèjàn

Ikún ìgbá keke ijọ èyé rèjàn ó mọn gbá keke o - ó rèjàn

Ikún ìfún rẹmun ijọ èyé rèjàn ó mọn fún rẹmun o - ó rèjàn

Ìjàn İjàn o — - ó rèjàn

Àlọ á rọ páàpáà ú rẹ giri íghẹe úchúrẹn, ú chú ùwánàle, á hẹ ini ígé gao ígé ìgú naa áàsẹ ve İjàn $\mathrm{o}$, u kúkú ìgú áàgbẹgẹeve ígé ìgú na ísue İjàn, bẹẹni. Sùgbọn ígé uran, ígé uchurẹn vá suwanle sí İjàn. Írá sì tún, ú vá hún ígé úwan sí osu, húnwan ínẹ sóòsún o, ú gbì soòsun á vèjàn. Uran va ... ígé úwànlè va idò uwa dọ isi yán á dọlù yán

Á doóivá. Ígé Oran va... Ígé úwànlè úwá sì ùkú, ú sùku áhù sí òdọ rẹrẹrẹrẹ, á gbàdádà úwọn sàpatá, á koji á gbimuda, a hùn ùji saàaran a é ígé uwan a kèègbègbè. A jiva í ú sà kerododi éswe. Uwan..Èye munwan ma ogorẹn ávè ùwà $o$, uwan mà á sà kòsẹn 0.

a hin....

İjàn, İjàn o - ó - o rèjàn

Kẹnikẹni mọnmọn rèjàn - ó rèjàn

Yío kann ó rejàn - ó rèjàn

Ogún ìgbá pata, ijọ eye rèjàn ó mọn gbá pata o - ó rèjàn

Omi ìfún rẹmun, ijọ èyé rèjàn ó mọn fún rẹmun o - ó rèjàn 


\section{Ye! Á hin Ye! Ye!}

Úgú èyévà hẹ Ye!, ìhẹ na áàse vè uwán òpín nẹn rẹn ve, ú hún uwan, hm! ú ve éswé oba, ú hẹ ma o ìhẹ naa hẹ naase ve o a úgú rẹn inẹ màávè o, Ain uwan un gbi ... uwan ma hẹ ùwánlèè gbi adádà o á hún ìmú dáà a o kòji 0 .

Ú dì erérè gào ìgú úsẹ péjọ ná ò hún ígé uwan vá ati èyévà, á ma dọjọ ìgu o, a hẹ uwan ùsẹn na à kò ìjòni èyé mẹ vòwà á hẹ ẹrin kòó.

Ú hin...

ikoye ikoye - adodo ikoye awulele

ikoye ikoye - adodo ikoye awulele

ibaba ikoye ikoye - adodo ikoye awulele

ùsẹn ina iko éswe, uwan á hẹ ẹrín kòó,

ú hin...

ikoye, ikoye - adodo ikoye awulele

ibaba ikoye ikoye - adodo ikoye awulele

Ú sì hun uwan lisi si eswe. Uwan asi di éswe uwan a si sako usẹn Ìjàn, İjàn o, ó rèjàn Ígé ugu èyévà ni opin inẹ áà pùwà, u sì jangiri si éswe ọ̣ba, ú sọjọ, uwan si di èégé á hẹe

ikoye ikoye- adodo ikoye awulele

èyévà si sẹ fẹetọduji!

baba ikoye - adodo ikoye awulele.

A a a, a hẹ ígé uwan wa ú yẹ usẹn ígé u naa hẹ u kòó, u yẹ kòó.

Ijú bá ri, òrun ti mù daa. Di a ke hun ve tẹrẹgó á pẹ igíri ígée úgú si èégé gwẹro, pe biju bá rii òdòrun ti $n$ gbu dáà. Pẹ ùràn uwọn a gún, íkú iru ràn íku.

İnọ ígé gwẹró.

Story $5 b$

Ìjàn, İjàn o

Ikún ì pá pata ijọ èyé rèjàn ó mọn pá pata o - ó rèjàn

Ikún ìgbá keke ijọ èyé rèjàn ó mọn gbá keke o - ó rèjàn

Ikún îfún rẹmun ijọ èyé rèjàn ó mọn fún rẹmun o - ó rèjàn

İjàn İjàn 0

- ó rèjàn

My story moves swiftly and centers on a woman who has a concubine that lives in a town called İjàn. There was famine in the town where she lives. An announcement was already made that no one should travel to İjàn for any reason. But then, because of the famine, 
the woman took her child and set out to Ìjàn. When she got there, her concubine gave her lots of things including plenty yams. After some time, the woman and her child set out to go back to their town. Her concubine turned into an eagle, he took a cutlass, palm-wine and water and followed them until they got home.

The following day, the woman left her child with the first wife and went to the farm. The child started to sing:

İjàn, İjàn o - - ó rèjàn

Kẹnikẹni mọnmọn rèjàn - ó rèjàn

Yío kann ó rejàn - ó rèjàn

Ogún ìgbá pata, ijọ eye rèjàn ó mọn gbá pata o - ó rèjàn

Omi ìfún rẹmun, ijọ èyé rèjàn ó mọn fún rẹmun o - ó rèjàn

The first wife shouted Ye! Á hin Ye! Ye! She was surprised that the second wife went to the town that they are forbidden to visit. She took the child to the palace and narrated the song she heard from the child. They told the child to repeat the song. The child started to sing thus:

ikoye ikoye - adodo ikoye awulele

ikoye ikoye - adodo ikoye awulele

ibaba ikoye ikoye - adodo ikoye awulele

They persuaded the child to repeat the song about İjàn but instead, the child continued to sing the song of ikoye, ikoye...

ikoye, ikoye - adodo ikoye awulele

ibaba ikoye ikoye - adodo ikoye awulele

The woman returned the child home dejected. When they got home, the child started to sing the song about İjàn, İjàn o, ó rèjàn... again. The woman took the child back to the palace so that people could listen to the song. When they got to the palace, the child started singing...

ikoye ikoye- adodo ikoye awulele

The woman was embarrassed!

baba ikoye - adodo ikoye awulele.

She shouted at the child to sing the real song for the people to hear but the people including the king were already angry at the woman. They accused her of telling a lie against the child. They said the mouth does not report everything that the eyes see.

So, they took her to 'ìtẹrẹggó' and beheaded her. That is the end of the story. 


\section{References}

Abney, S. (1987). The English noun phrase in its sentential aspect. Dissertation, MIT., Cambridge, Mass.

Aboh, E. O. (1998). "On the Syntax of Gungbe Noun Phrases". Clearing house on Languages and Linguistics ERIC Documentation Reproduction service. No ED 420 209.

Aboh, E.O. (2004). The morphosyntax of Complement-Head Sequences. Clause structure and word order patterns in Kwa. Oxford University Press, New York.

Aboh, E. O. (2004). Topic and focus within D. Linguistics in the Netherlands 21-112.

Aboh, E. O. (2007). A 'mini'relative clause analysis for reduplicated attributive adjectives. Linguistics in the Netherlands, 24(1), 1-13.

Adger, D., \& Harbour, D. (2008). Why phi? In Phi-Theory: Phi Features across Modules and Interfaces, edited by Daniel Harbour, David Adger, \& Susana Béjar, pp. 1-34.

Oxford University Press, Oxford.

Acquaviva, P. (2008). Lexical plurals: A morphosyntactic approach. Oxford University Press, Oxford, UK.

Adénúgà, P.L. (2014). Focus constructions in Ògè. MA. Thesis, (Unpublished Master's Thesis), University of Ilorin, Ilorin.

Adénúgà, P.L. (2015). Focus Constructions in Ògè. Language Endangerment:

Globalisation and the Fate of Minority Languages in Nigeria: Festschrift in Honor of Appolonia U. Okwdudishu.

Adénúgà, P.L. (2017). Negation in Ògè. Alore: Journal of the Humanities, University of Ilorin, Kwara State. Nigeria.

Adénúgà, P.L. (2019). Plural Marking with òtúro in Ògè. In Astrid van Alem, Mirella De 
Sisto, Elisabeth J. Kerr \& Joanna Wall (eds), ConSOLE XXVII: Proceedings of the $27^{\text {th }}$ Conference of the Student Organization of Linguistics in Europe, 84-105.Leiden: Leiden University Centre for Linguistics.

Adénúgà, P.L. (to appear). Nominal Attributive Modifiers (NAMs) in Ògè. In $\mathrm{A}^{\mathrm{O}}$ :

The Lexical Status of

https://benjamins.com/\#catalog/books/lfab/main

Adésọlá, O. (2005). Pronouns and null operators: A-bar dependencies and relations in

Yorùbá. Rutgers The State University of New Jersey-New Brunswick.

Adger, D. (2003). Core syntax: A minimalist approach (Vol. 33). Oxford: Oxford University Press.

Adger, D. (2010). A minimalist theory of feature structure. In Features: Perspectives on a Key Notion in Linguistics, edited by Anna Kibort and Greville G. Corbett, pp. 185218. Oxford University Press, Oxford.

Ajíbóyè, O. (2001). The internal structure of Yorùbá DP, 32nd Annual conference of African Linguistics. University of Califonia, Berkeley.

Ajíbóyè, Ọ., Dechaine R., \& Stewart, O. (2003). On the syntax of Nominalization in Edo and Yorùbá. Kinyira njira! Step firmly on the pathway, 23-24.

Ajíbóyè, Ọ. (2005). Topics on Yorùbá nominal expressions. Dissertation, University of British Columbia.

Ajíbóyè, O. (2007). "On the status of the Mid toned $t i$ in Yorùbá Nominal Genitives.” In Ozo-mekuri Ndimele (ed.). Convergence: English \& Nigerian Languages. A Festschrift for Munzal A. Jibril. 943-956.

Ajíbóyè, Ọ. (2009). “Analyzing Yorùbá Bare nouns as DP”. In Lagos Notes \& Records. Volume 15: 30-55. Lagos, Nigeria. Lagos. 
Ajíbóyè, Ọ. (2010). Plural strategies in Yorùbá. Studies in African Linguistics, 39(2):141181.

Akinlabí, A., \& Adésolá, O. (2018). Possessive unaccusatives in Yorùbá. In Adesola, Akinlabi and Ọla (eds). Data-Rich Linguistics: Papers in Honor of Yíwọlá Awóyalé Cambridge Scholars Publishing.

Alexiadou, A. (2001). Adjective syntax and noun raising: word order asymmetries in the DP as the result of adjective distribution. Studia Linguistica 55, 217-248.

Alexiadou, A., Haegeman, L., \& Stavrou, M. (2007). Noun Phrases in the Generative Perspective Berlin/New York: Mounton de Gruyter.

Alexiadou, A. (2010). Nominalizations: A probe into the architecture of grammar Part 1: The nominalization puzzle. Language \& Linguistics compass, 4(7), 496-511.

Alexiadou, A. (2019). Morphological and semantic markedness revisited: The realization of plurality across languages. Zeitschrift für Sprachwissenschaft 38: 123154.

Aljovic, N. (2010). Syntactic positions of attributive adjectives. In Adjectives: Formal analyses in syntax and semantics, ed. By Patricia Cabredo Hofherr and Ora Matushansky, 29-51. Amsterdam: John Benjamin.

Aronoff, M., \& Fudeman, K. (2011). What is morphology? (Vol. 8). John Wiley \& Sons.

Awóbùlúyì, Ọ. (1972). “On the Classification of Yoruba Verbs.” In A. Bamgbose (Ed.), The Yoruba Verb Phrase. Ibadan: University of Ibadan Press. 119-134. Awóbùlúyì, O. (1978a). Essentials of Yorùbá Grammar. Oxford University Press, Ìbàdàn. Awóbùlúyì, Ọ. (1992). Aspects of Contemporary Standard Yoruba Dialectological 
Perspective. In Akinwumi Isola (ed). New Finding in Yoruba Studies, J. F. Odunjo Memorial Lecture, No. 2, Ibadan: Johnmof Printer:43-62.

Awóbùlúyì, Ọ. (2013). Official Language Policies in Africa. In Selected Proceedings of the $43^{\text {rd }}$ Annual Conference on African Linguistics, ed. Olanike Ola Orie and Karen W. Sanders Somerville, MA Cascadilla Proceedings Project (pp. 68-76).

Awóyalé, Y. (1989). Reduplication and the status of Ideophones in Yorùbá. The journal of West-African Languages XIX,1.

Babby, L. H. (1998). Voice and diathesis in Slavic. In Position paper presented at the Workshop on Comparative Slavic Morphosyntax: State of the Art. Indiana University, Spencer.

Bailyn, J. (1994). The Syntax and Semantics of Russian Long and Short Adjectives: an X'-Theoretic Account. In J. Toman, ed., Annual Workshop on Formal Approaches to Slavic Linguistics. The Ann Arbor Meeting, 1-30. Ann Arbor: Michigan Slavic Publications.

Baker, M. (2003). Verbs, Nouns, and Adjectives: their Universal Grammar. Cambridge, MA: Cambridge University Press.

Bale, A., Gagnon, M., \& Khanjian, H. (2011). On the relationship between morphological and semantic markedness. Morphology 21(2): 197-221.

Bale, A. \& Khanjian, H. (2014). Syntactic complexity and competition: The singularplural distinction in Western Armenian. Linguistic Inquiry 45: 1-26.

Bámgbósé, A. (1974). “On Serial Verbs and Verbal Status”. The Journal of West African Languages (J.W.A.L), 9.1:17-48.

Bámgbósé, A. (1990). Fonộlọjì àti Gírámá Yorùbá. Ibadan: University Press PLC: 157160. 
Bernstein, J. (1991). DPS in French and Walloon: Evidence for parametric variation in nominal head movement. Probus 2, 1-26.

Bernstein, J. (1993). Topics in the syntax of nominal structure across Romance. Ph.D. Dissertation, CUNY.

Biloa, E. (1995). Functional categories and the syntax of focus in Tuki. Studies in African Linguistics. Munchen: Lincom Europa, Lincom.

Borer, H. (2005). In name only. Oxford: Oxford University Press.

Borik, O., \& Espinal, M. (2014). Reference to kinds and to other generic expressions in spanish: definiteness and number. The Linguistic Review 1, pp. 1-58.

Bosque, I., \& Picallo, C. (1996). Postnominal adjectives in Spanish DPs. Journal of linguistics, 32(2), 349-385.

Bruening, B. (2010). Ditransitive asymmetries and a theory of idiom formation. Linguistic Inquiry, 41(4), 519-562.

Bruening, B. (2013). By phrases in passives and nominals. Syntax, 16(1), 1-41.

Bošković, Ž. (2005). On the locality of left branch extraction and the structure of NP. Studia Linguistica 59: 1-45.

Bošković, Ž., \& Gajewski, J. (2008). Semantic correlates of the NP/DP Parameter. Paper presented at NELS 39, Cornell University.

Bošković, Ž. (2009). More on the no-DP Analysis of Articleless Languages. Studia Linguistica 63 (2), 187-203.

Butler, L.K. (2011). The morphosyntax and processing of number marking in Yucatec Maya. Tuscon, AZ: University of Arizona dissertation.

Caruso, D. Z. (2012). The syntax of nominal expressions in articleless languages: a split DP-analysis of Croatian nouns. 
Cheng, L. L-S. \& Sybesma, R. (1999). Bare and not-so-bare nouns and the structure of NP. Linguistic Inquiry 30(4). 509-542. DOI: https://doi. org/10.1162/002438999554192.

Cormack, A. \& Breheny, R. (1994). Projections for Functional Categories. In UCL Working Papers in Linguistics 6: 35-61.

Cecchetto, C. \& Donati, C. (2010). On labeling: Principle C and head movement. Syntax $13: 241-278$.

Chierchia, G., \& Turner, R. (1988). 'semantics and property theory'. Linguistics and philosophy $11,261-302$.

Chomsky, N. (1970). Remarks on Nominalization. In R. A. Rosenbaum (Ed.), Readings in Transformational Grammar (pp. 184-221). Waltham, MA: Ginn.

Chomsky, N. (1975). The logical structure of linguistic theory. New York: Plenum.

Chomsky, N. (1981). Lectures on government and binding. Dordrecht: Foris Publications. Chomsky, N. (1986). Barriers. Cambridge MA: MIT Press.

Chomsky, N. (1994). Bare phrase structure (Vol. 8). MIT Press.

Chomsky, N. (1995). The Minimalist Program. Cambridge, MA: MIT Press.

Chomsky, N. (1995). Base phrase structure. In G. Webelhuth, Government and Binding Theory and the Minimalist Program (pp.383-439). Massachusetts. Basil Blackwell Inc.

Chomsky, N. (1998). Minimalist inquiries: The framework. MIT Occasional Papers in Linguistics 15.

Chomsky, N. (2000). Minimalist inquiries. In Essays on minimalist syntax in honor of Howard Lasnik, Roger Martin, David Michaels, \& Juan Uriagereka, eds., Cambridge, MA: MIT Press, 89-155. 
Chomsky, N. (2001). Beyond explanatory adequacy. MIT occasional papers in linguistics 20. Cambridge: Department of Linguistics and Philosophy, MITWPL, MIT.

Cinque, G. (1994). On the evidence of partial N movement in the Romance DP. In Paths towards Universal Grammar: Studies in honor of Richard S. Kayne, ed. by Guglielmo C Jan Koster, Jean-Yves Pollock, Luigi Rizzi, nuttini, 85-110. Washington, DC: Georgetown Press.

Cinque, G. (1995). Italian syntax and universal grammar. No. 77. Cambridge University Press.

Cinque, G. (2003). The Prenominal Origin of Relative Clauses. Paper presented at the Workshop on Antisymmetry and Remnant Movement, NYU, Oct. 31 October- Nov.1, 2003.

Cinque, G. (2008a). Two Types of Nonrestrictive Relatives. In O. Bonami and P. Cabredo Hofherr, (eds.), Empirical Issues in Syntax and Semantics 7. 99 -137. Paris: CNRS (http://www.cssp.cnrs.fr/eiss7).

Cinque, G. (2010). The Syntax of Adjectives. A Comparative Study. Cambridge, MA.: MIT Press.

Cinque, G. (2014). The Semantic Classification of Adjectives. A View from Syntax. Studies in Chinese Linguistics, Volume 35, Number 1, 1-30.

Collins, C. (2002). Eliminating labels. In S. D. Epstein \& T. D. Seely (eds.), Derivation and explanation in the minimalist program, 45-61. Oxford: Blackwell.

Corbett, G. (2000). Number. Cambridge University Press, Cambridge, UK.

Corbett, G. (2004). The Russian Adjective: A Pervasive yet Elusive Category. In R. M. W. Dixon and A. Aikhenvald, eds., Adjective Classes. A Cross-Linguistic Typology, 
199-221. Oxford: Oxford University Press.

Corbett, G. (2006). Agreement. Cambridge University Press.

DOI: https://doi.org/10.1017/CBO9781139164344

Creissels, D. (2016). Noun + adjective compounding and quasi-compounding in the languages of Sub-Saharan Africa.Syntax of the World's Languages 7 Mexico.

Cysouw, M. (2001). The Paradigmatic Structure of Person Marking. Oxford Studies in Typology and Linguistic Theory. Oxford University Press. 2003. ISBN 019925412 5. pp. $375+X$.

Dechaine, R-M. (1992). Inflection in Ìgbò and Yorùbá. MIT Working Papers in Linguistics, 17, 95-120.

Déchaine, R-M. (1993). Predicates Across Categories. Ph. D. dissertation, University of Massachusetts, Amherst.

Delsing, L. O. (1993). On attributive adjectives in Scandinavian and other languages. Studia linguistica, 47(2), 105-125.

Dixon, R. M. W. (1982). The Dyirbal Language of North Queensland. Cambridge: Cambridge University Press.

Dixon, R.M.W. (2004). Adjective Classes in Typological Perspective. In R.M.W. Dixon and A. Aikhenvald, eds., Adjective Classes. A Cross-Linguistic Typology, 1-49. Oxford: Oxford University Press.

Duanmu, S. (2005). The tone-syntax interface in Chinese: some recent controversies. In Proceedings of the Symposium "Cross-Linguistic Studies of Tonal Phenomena, Historical Development, Tone-Syntax Interface, and Descriptive Studies (pp. 16-17).

Ẹlẹshin, A. A. (2017). A unified analysis of Nominalisation in Yorùbá. (Unpublished doctoral dissertation). University of Lagos, Nigeria. 
Embick, D. \& Marantz, A. (2008). Architecture and blocking. Linguistic Inquiry, 39, 153.

Enç, M. (1991) 'The Semantics of Specificity.’ Linguistic Inquiry 22: 1-26.

Fabb, N.A.J. (1984). Syntactic affixation (Doctoral dissertation, Massachusetts Institute of Technology).

Fábregas, A. (2008). A two sources for nominal features in Spanish Nominalizations.

Fodor, J. D., \& Sag, I. A. (1982). 'Referential and Quantificational Indefinites', Linguistics and Philosophy 5, 355-398.

Galloway, B. (1980). The structure ofupriver Halkomelem, a grammatical sketch and classified word list for upriver Halkomelem. Sardis: Coqualeetza Education Training Center. Galloway, B. (1993). A grammar ofupriver Halkomelem. Berkeley: University of California Press.

Ghomeshi, J. (2003). Plural marking, indefiniteness, and the noun phrase. Studia Linguistica 57. 47-74. DOI: https://doi.org/10.1111/1467-9582.00099

Groenendijk, J., Janssen, T., \& Stokhof, M. (1981). Formal Methods in the Study of Language, Mathematisch Centrum, Amsterdam.

Guillemin, D. (2009). The Mauritian Creole noun phrase: Its form and function. Unpublished PhD dissertation, University of Queensland.

Guillemin, D. (2011). The syntax and semantics of a determiner system: A case study of Mauritian Creole. Amsterdam: John Benjamins.

Guillemin, D. (2014). Marking Definiteness or Specificity, not necessarily both. Studies in Language Companion Series (SLCS), 193.

Halle, M., \& Alec, M. (1993). "Distributed Morphology and the pieces of Inflection.” In 
The view from Building 20, edited by Ken Hale and Samuel Jay Keyser, 111-76. Cambridge, MA: MIT Press.

Halle, M., \& Matushansky, O. (2006). The morphophonology of Russian adjectival inflection. Linguistic Inquiry 37(3). 351-404. DOI: https://doi.org/10.1162/ ling.2006.37.3.351.

Hartmann, K., \& Zimmermann, M. (2003). Syntactic and semantic adnominal genitive. na.

Hawkins, J. A. (1978). Definiteness and Indefiniteness: A Study in Reference and Grammaticality Prediction. London: Croom Helm.

Hornstein, N. (2009). A theory of syntax: Minimal operations and universal grammar. Cambridge: Cambridge University Press.

Hyman, L. \& Watters, J. R. (1984). Auxiliary focus. Studies in African Linguistics, 15, $233-273$.

Ihsane, T., \& Puskás, G. (2001). Specific is not definite. GG@ G, 2, 39-54.

Iljic, R. (1994). Quantification in Mandarin Chinese: Two markers of plurality. Linguistics 32.91-116. DOI: https://doi.org/10.1515/ling.1994.32.1.91

Ìlọ̀rí, J. F. (2016). 'Categorial Status of Yoruba Attributives Modifiers', Ihafa: A Journal of African Studies Volume 8 Number 2, 124-152.

Jackendoff, R. S. (1977). X'-Syntax. A Study of Phrase Structure. Cambridge, Mass.: MIT Press.

Kang, H. S. (2005). On the adjective in Korean. Working Papers in Linguistics, 15, 2005, pp. 153-169.

Kayne, R. S. (1994). The antisymmetry of syntax. Cambridge, MA: MIT Press.

Kim, M. J. (2002). Does Korean have adjectives. MIT Working Papers in Linguistics, 43, 
71-89.

Kim, J. N. (2005). A Research on Korean Adjectives.

Kim, K., \& Melchin, P. B. (2018). Modifying plurals, classifiers, and co-occurrence: The case of Korean. Glossa: a journal of general linguistics 3(1): 25. 1-29.

Kinyalolo, Kasangati K. W. (1995) ‘Licensing in DP in Fon’, Linguistique Africaine 14. $61-92$

Koopman, H. (1993). The internal structure of the pronominal DP, and the syntactic distribution of pronouns (paper read at the research seminar. University of Geneva).

Kramer, R. (2009). Definite markers, phi-features, and agreement: A morphosyntactic investigation of the Amharic DP Santa Cruz, CA: University of California dissertation.

Kramer, R. (2012). A split analysis of plural: Evidence from Amharic. In Nathan Arnett \& Ryan Bennett (eds.) Proceedings of the 30th West Coast Conference on Formal Linguistics, 226236. Somerville, MA: Cascadilla Proceedings Project.

Kramer, R. (2015). The morphosyntax of gender (Vol. 58). Oxford University Press.

Li, C. N., \& Thompson S. A. (1981). Mandarin Chinese: a Functional Reference Grammar. Berkeley: University of California Press.

Lobeck, A. C. (1995). Ellipsis: Functional heads, licensing, and identification. Oxford University Press on Demand.

Longobardi, G. (1994). Reference and proper names: A theory of N-movement in syntax and Logical Form. Linguistic Inquiry 25:609-665.

Longobardi, G. (2001). The Structure of DPs. Principles, Parameters and Problems. In: Handbook of Syntactic Theory, M. Baltin \& C. Collins, 562-603. Cambridge, Mass. Oxford: Blackwell.

Lowenstamm, J. (2008). On little n, $\sqrt{ }$, and types of nouns. Sounds of silence: Empty 
elements in syntax and phonology, 105, 144.

Ludlow, P., \& Neale, S. (1991). Indefinite descriptions: In defense of Russell.

Linguistics and philosophy, 14(2), 171-202.

Lyons, C. (1999). Definiteness. Cambridge: Cambridge University Press. DOI:

https://doi.org/10.1017/CBO9780511605789

Manfredi, V. (1992). A typology of Yorùbá nominalizations. In Chris Collins and Victor Manfredi, eds., Proceedings of the Kwa Comparative Syntax Workshop. Cambridge, MA: MIT Working Papers in Linguistics.

Manfredi, V. (2018). The referential prosody of bare arguments. http://people.bu.edu/manfredi/ReferentialProsody.pdf

Marantz, A. (2001). Words. Paper presented at WCCFL XX, University of Southern California, Los Angeles.

Müller, G. (2002). Remarks on nominal inflection in German. More than words: a festschrift for Dieter Wunderlich, 2002, 113-145.

Murphy, A. (2018). Pronominal inflection and NP ellipsis in German. The Journal of Comparative Germanic Linguistics, 21(3), 327-379.

Newman, P.S. (2000). The Hausa Language. An Encyclopedic Reference Grammar. New Haven: Yale University Press.

Nweya, G.O. (2016). Plural marking strategies and devices in Igbo. Kansas Working Papers in Linguistics. Vol. 37 pp.1-22.

Ọlá, O. (1995). Optimality in Benue-Congo prosodic phonology and morphology. Ph.D. Thesis, UBC, Vancouver.

Oyèláràn, O. O. (1989). Morphological and syntactic constraints on verbal auxiliaries in Yorùbá, paper presented at the 4th Niger-Congo Syntax and Semantics Workshop, 
Universiteit van Tilburg, 3 June.

Pesetsky, D. (1987). Wh-in-situ: Movement and unselective binding. In The Representation of (In)definiteness, Eric J. Reuland \& Alice G. B. ter Meulen (eds), 98-129. Cambridge MA: The MIT Press.

Pereltsvaig, A. (2006). Small Nominals. Natural Language and Linguistic Theory 24: 433-500.

Popjes, J., \& Popjes, J. (1986). “Canela-Krahô”. In: Desmond C. Debyshire \& Geoffrey K. Pullum (eds.) Handbook of Amazonian Languages. Vol. 1, pp. 128-199. Berlin: Mouton de Gruyter.

Pulleyblank, D. (2008). Patterns of reduplication in Yorùbá. In The Nature of the Word: Essays in Honor of Paul Kiparsky, Kristin Hanson and Sharon Inkelas (eds.). Cambridge, MA: MIT Press.

Ritter, E. (1991). Two functional categories in modern Hebrew noun phrases. Syntax and Semantics 25, Perspectives on phrase structure: Heads and licensing. Academic Press, New York, pp. 37-60.

Ritter, E. (1995). On the syntactic category of pronouns and agreement. Natural Language and Linguistic Theory 13, 405-433.

Roehrs, D. (2006). The morpho-syntax of the Germanic noun phrase: Determiners move into the determiner phrase. Indiana University.

Roehrs, D., \& Julien, M. (2014). “Adjectives in German and Norwegian.” Adjectives in Germanic and Romance 212: 245-261.

Sag, Y. (2017). The semantics of numeral constructions in Turkish. Sinn und Bedeutung (SuB), 22, 307-324.

Seely, T. D. (2006). Merge, derivational c-command, and subcategorization. In C. 
Boeckx (ed.), Minimalist essays, 182-217. Amsterdam: John Benjamins.

Segerer, G. (2008). Closed adjective classes and primary adjectives in African

Languages. SHS:LANGUE. Unpublished Work (http://halshs.archivesouvertes.fr/halshs-00255943).

Sigurodsson, H. Á. (1993). The structure of the Icelandic NP. Studia Linguistica, 47(2), 177-197.

Smith, P. W. (2015). "Feature mismatches: Consequences for syntax, morphology and semantics". PhD thesis. Storrs, CT: University of Connecticut.

Sohn, H-M. (1994). Korean. London: Routledge.

Sportiche, D. (1994). Adjuncts and Adjunction. GLOW Newsletter 32: 54-55.

Sportiche, D. (1995). Clitic constructions. Phrase structure and the lexicon. In Johan Rooryck and Laurie Zaring (eds.), 213-276. Springer, Dordrecht.

Sproat, R., \& Shih, C. (1988). Prenominal adjectival ordering in English and Mandarin. Proceeding of NELS 12: 465-489.

Sproat, R., \& Shih, C. (1991). The Cross-linguistics distribution of adjectival ordering restrictions. In Interdisciplinary Approaches to Language: Essays in Honor of S-Y. Kuroda, ed. C. Georgopoulos, and R. Ishihara, 565-593. Dordrecht: Kluwer.

Stowell, T. (1989). Subjects, specifiers, and X-bar theory. Alternative conceptions of phrase structure. In M. R. Baltin \& A. S. Kroch (Eds.). 232-262. Chicago: University of Chicago Press.

Stowell, T. (1991). Determiners in NP and DP. Views on phrase structure. In K. Leiffel \& D. Bouchard (Eds.). Dordrecht: Kluwer.

Stockwell, R. (2016). Labeling in Syntax. Cambridge Occasional Papers in Linguistics 9, 130-155. 
Svenonius, P. (1992). The Extended Projection of N: Identifying the Head of the Noun Phrase.

Svenonius, P. (1993). Selection, Adjunction, and Concord in the DP. Studia Linguistica 47 (2), 198-220.Working Papers in Scandinavian Syntax 49.95-121.

Svenonius, P. (1994). 'the structural location of the attributive adjective'. In E. Duncan, D.Farkas, and P. Spaelti (Eds.), Proceedings of the 12th West Coast Conference on Formal Linguistics, Stanford, pp. 439-454. CSLI.

Svenonius, P. (2017). Syntactic features. CASTL, University of Troms $\phi$ - The Arctic University of Norway.

Szabolcsi, A. (1981). The possessive construction in Hungarian: a configurational category in a non-configurational language. Acta Linguistica Scientiarum Academiae Hungaricaae, 31, 261-289.

Szabolcsi, A. (1987). Functional categories in the noun phrase. In Approaches to Hungarian, 167-189.

Szabolcsi, A. (1994). The noun phrase. In Syntax and semantics 27: The syntactic structure of Hungarian. In F. Kiefer \& K. Kiss (Eds.). San Diego, Calif.: Academic Press.179-274.

Talić, A. (2017). Long-Form and Short-Form Prenominal Adjectives Are Not Reduced Relative Clauses in Bosnian/Croatian/Serbian. Linguistic Inquiry, 48(1), 194-212.

Truswell, R. (2004a). Attributive Adjectives and the Nominals They Modify. M.Phil. Thesis, University of Oxford (http://www.tufts.edu/ rtrusw01/mphil.pdf).

Tsoulas, G. (2007). On the grammar of number and mass terms in Greek. MIT Working Papers in Linguistics 49: 239-266.

Uriagereka, J. (2003). Pure adjuncts. Ms., University of Maryland. 
Von Heussinger, K. (2002). Specificity and definiteness in sentence and discourse structure. Journal of semantics 19:245-274 Liliane M. V. Haegeman, 95-124. London: Longman.

Welmers, W. (1973). African Language Structures. Berkeley: University of California Press.

Whitman, J. (1981). "The Internal Structure of NP in Verb Final Languages," Proceedings of the Chicago Linguistic Society 17: 411-418.

Whorf, B. L. (1945). Grammatical categories. Language, 21, 1-11.

Wiltschko, M. (2008). The syntax of non-inflectional plural marking. Natural Language and Linguistic Theory 26. 639-694.

Yusuf, O. (1990). Yoruba copular ni. Journal of West African Languages, 20(1), 83-93.

Zeijlstra, H. (2014). 'On the uninterpretability of interpretable features' In P. Kosta, S. Franks, Th. Radeva-Bork \& L. Schürcks (eds.), Minimalism and beyond. Amsterdam: Benjamins. 109-129.

Zeijlstra, H. (2020). Labelling, selection and feature checking. In Smith, P. W., Mursell, J., \& Hartmann, K. (Eds.). Agree to Agree: Agreement in the Minimalist Programme (Open Generative Syntax 6). Berlin: Language Science Press.

Ziff, P. (1960). Semantic Analysis. Ithaca, NY. 


\section{An die/den}

Vorsitzende/n des Promotionsausschusses

des Fachbereichs 10

Neuere Philologien

Norbert-Wollheim-Platz 1

60629 Frankfurt

dekanat10@lingua.uni-frankfurt.de

\section{Erklärungen von:}

Priscilla Lola Adénúgà

Hiermit erkläre ich,

a) dass ich die eingereichte Arbeit selbstständig verfasst und nur die in der Dissertation angegebenen Hilfsmittel in Anspruch genommen habe [gem. $\S 8$ Abs. 3 (d) Promotionsordnung des Fachbereichs].

b) dass die eingereichte Arbeit noch nicht bei einem anderen Prüfungsverfahren eingereicht wurde [gem. $\S 8$ Abs. 3 (e) Promotionsordnung des Fachbereichs].

c) dass mir die Promotionsordnung bekannt ist [gem. $§ 8$ Abs. 3 (g) Promotionsordnung des Fachbereichs].

d) dass ich nicht schon einmal eine Promotion im Promotionsfach erfolglos versucht habe [gem. §8 Abs. 5 (e) Promotionsordnung des Fachbereichs].

e) dass die Arbeit nicht bereits in einem anderen Promotionsfach erfolgreich eingereicht wurde [gem. §8 Abs. 5 (f) Promotionsordnung des Fachbereichs]

f) dass mir folgendes bekannt ist: Die Arbeit kann ganz oder teilweise vorab veröffentlicht worden sein [gem. §9 Abs. (2) Promotionsordnung des Fachbereichs]

Hinweis: Eine Vorveröffentlichung in größerem Umfang bedarf der Genehmigung des

Promotionsausschusses. Falls eine Vorveröffentlichung in größerem Umfang beabsichtigt wird, ist mit dem Dekanat Rücksprache zu halten.

g) dass ich die Grundsätze guter wissenschaftlicher Praxis bei der Erstellung meiner Dissertation beachtet habe [Allgemeine Bestimmungen für die Promotionsordnungen der Goethe-Universität vom 12.12.2012].

h) dass ich für meine Promotion nicht die Hilfe einer professionellen Promotionsvermittlung in Anspruch genommen habe [Allgemeine Bestimmungen für die Promotionsordnungen der GoetheUniversität vom 12.12.2012].

i) dass ich der Arbeit eventuell zugrunde liegende Daten 10 Jahre lang zugänglich halten werde (personenbezogene Daten müssen anonymisiert werden) [Allgemeine Bestimmungen für die Promotionsordnungen der Goethe-Universität vom 12.12.2012].

Wiesbaden, 06.10.2020

Ort, Datum

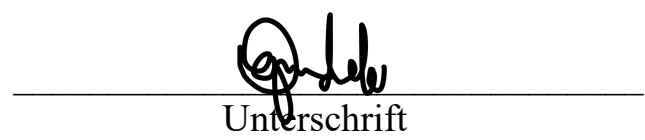

Fachbereich Neuere Philologien (FB 10) • Dekanat

Campus Westend $\bullet$ Norbert-Wollheim-Platz $1 \bullet 60629$ Frankfurt am Main 